Three Centuries of

1015

in East Timor

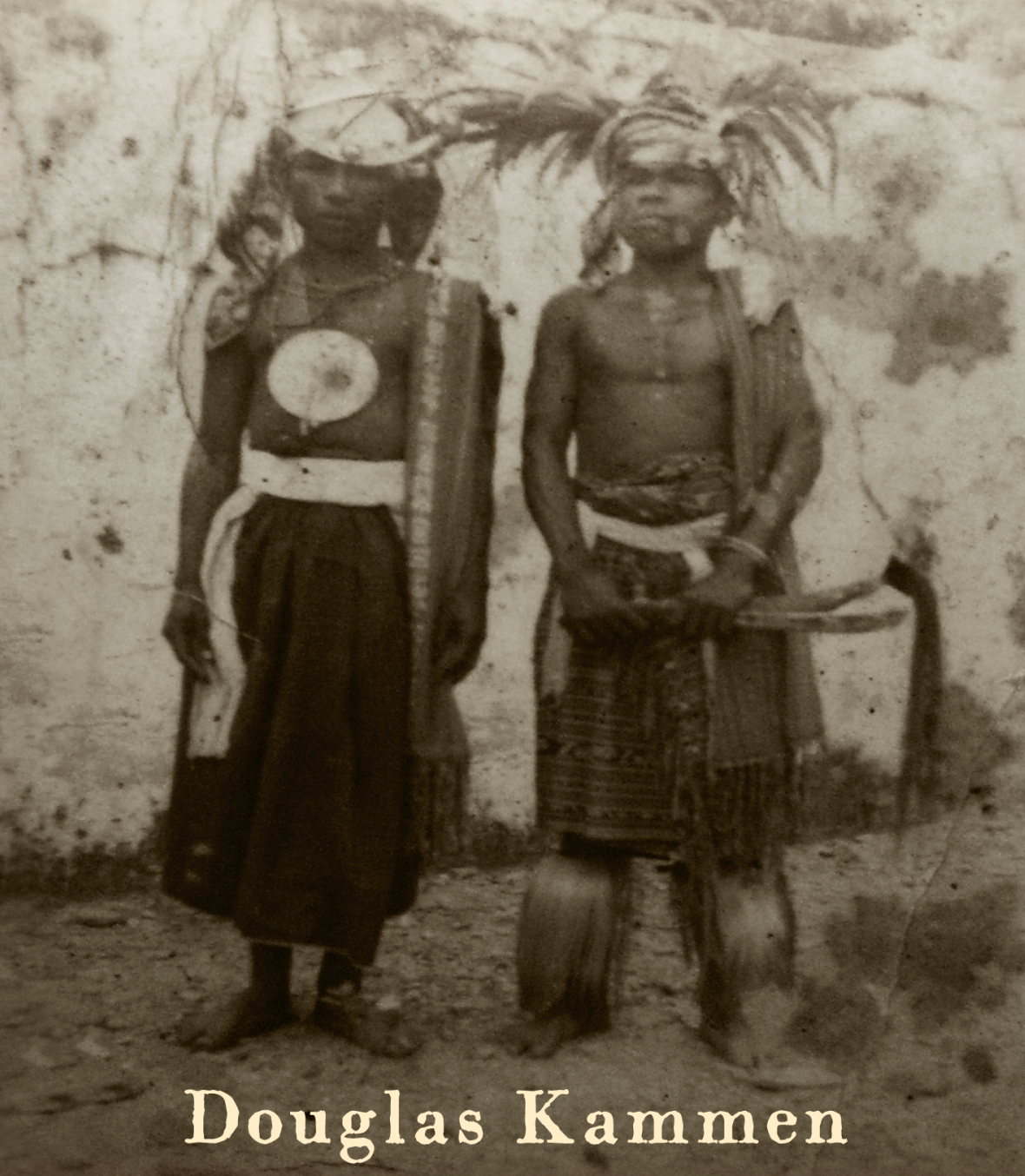




\section{Three Centuries of}

Conflict in East Timor 


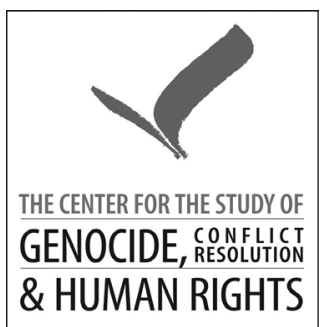

\section{Genocide, Political Violence, Human Rights Series}

Edited by Alexander Laban Hinton, Stephen Eric Bronner, and Nela Navarro

Alan W. Clarke, Rendition to Torture

Lawrence Davidson, Cultural Genocide

Daniel Feierstein, Genocide as Social Practice: Reorganizing

Society under the Nazis and Argentina's Military Juntas

Alexander Laban Hinton, ed., Transitional Justice: Global Mechanisms and Local Realities after Genocide and Mass Violence

Alexander Laban Hinton, Thomas La Pointe, and Douglas Irvin-Erickson, eds., Hidden Genocides: Power, Knowledge, Memory

Douglas Kammen, Three Centuries of Conflict in East Timor

Walter Richmond, The Circassian Genocide

Irina Silber, Everyday Revolutionaries: Gender, Violence, and Disillusionment in Postwar El Salvador

Samuel Totten and Rafiki Ubaldo, eds., We Cannot Forget: Interviews with Survivors of the 1994 Genocide in Rwanda Ronnie Yimsut, Facing the Khmer Rouge: A Cambodian Journey 


\section{Three Centuries of Conflict in East Timor}

DOUGLAS KAMMEN

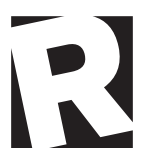

RUTGERS UNIVERSITY PRESS

NEW BRUNSWICK, NEW JERSEY, AND LONDON 


\section{LIBRARY OF CONGRESS CATALOGING-IN-PUBLICATION DATA}

Kammen, Douglas Anton, author.

Three centuries of conflict in East Timor / Douglas Kammen.

pages $\mathrm{cm}$-(Genocide, political violence, human rights series)

Includes bibliographical references and index.

ISBN 978-0-8I35-74IO-3 (hardcover : alk. paper)-ISBN 978-o-8I35-74II-O (e-book (epub))-ISBN 978-o-8I35-74I2-7 (e-book (web pdf))

I. Timor-Leste-History. 2. Political violence-Timor-Leste-History. I. Title. II. Title: 3 centuries of conflict in East Timor.

DS649.5.K36 2015

959.87-dc23

20I404I36I

A British Cataloging-in-Publication record for this book is available from the British Library.

Copyright (@) 2015 by Douglas Kammen

All rights reserved

No part of this book may be reproduced or utilized in any form or by any means, electronic or mechanical, or by any information storage and retrieval system, without written permission from the publisher. Please contact Rutgers University

Press, I06 Somerset Street, New Brunswick, NJ 089or. The only exception to this prohibition is "fair use" as defined by U.S. copyright law.

Visit our website: http://rutgerspress.rutgers.edu

Manufactured in the United States of America 


\section{CONTENTS}

Preface vii

Note on Place Names, Personal Names, and Spelling $\quad$ xi

Glossary and Abbreviations xiii

Introduction: Situating Recurrent Mass Violence 1

1 Contested Origins 23

2 Maubara and the Dutch East India Company 42

3 Vassalage and Violence, I86I-I887 61

4 The Uprising and Devastation of I893 79

5 High Colonialism and New Forms of Oppression, I894-I974 96

6 The End of Empire and the Indonesian Occupation, $\begin{array}{ll}\text { I974-I998 } & 119\end{array}$

7 Serious Crimes and the Politics of the Past, I999-2OI2 143 Epilogue

Appendix: Lineages of Major Families in Maubara

Notes

Bibliography

Index 



\section{PREFACE}

The his project began soon after I moved to Dili in 200I to teach at the newly established National University of East Timor. Before then my knowledge of East Timor was limited to a rather casual study of the Indonesian military units that had served in the occupied territory. Not knowing where to begin, I visited the cemeteries, the closest I could come to an archive. In the Santa Cruz cemetery, where Indonesian troops opened fire on a peaceful funeral procession in I99I, I was intrigued by a gravestone for three brothers who, the inscription told me, had been "murdered in Maubara" in September 1975. Knowing little about East Timor's history and nothing whatsoever about Maubara, I could not have imagined that this gravestone would lead three centuries back into Maubara's past and forward a quarter century to East Timor's independence and beyond. Nor could I have imagined that the village in which the three brothers were born and killed was also the home of an extraordinary nineteenth-century rebel leader; that the brothers' Timorese grandmother had been the mistress of the son of a brutal Portuguese governor; that their grandfather was deported from Portugal for pro-Republican activities; that one of their cousins was a member of the Fretilin Central Committee in 1975; that the great-great nephew of the nineteenth-century rebel leader was the district administrator and pro-Jakarta militia organizer in I999; or that the first man murdered by the pro-Jakarta militia in early I999 was a direct descendant of the ruler of Maubara in I726. My apparently innocent question about who killed three boys in 1975 led from hamlet to hamlet, from Maubara to Dili, from there to Portugal and Holland, from slaves brought from the Dutch-held island of Alor to the governor of Portuguese Timor, from failed decolonization in 1975 to the Serious Crimes Unit tasked with investigating human 
rights abuses after I999, and from subsistence peasants to independent East Timor's new elite.

A project of this sort would not have been possible without the assistance, input, and encouragement of a great many people. People in Maubara and elsewhere in East Timor patiently listened to my questions and told me what they knew, thought they knew, or wanted me to know. In Maubara I am particularly grateful to Felix da Costa, Mau Dua, José Maucabae, José Lino dos Reis, Miguel Sanches, José Serra, Lourindo dos Reis da Silva, and Fortunato Soares. I am deeply indebted to Martinho and Julião (of the sacred hair), who served as guides on adventures through the forests and kept me company on chilly nights camping on the mountaintop. In Dili, I learned an enormous amount from my colleagues and students at the National University of East Timor. My colleague Abel dos Santos, who is from Maubara, first introduced me to the area and for more than a decade has been a source of information, contacts, and friendship. I would also like to acknowledge the assistance and encouragement of a number of friends: Emma Coupland, Alex Grainger, Janet Gunter, Selma Hayati, Nugroho Katjasungkana, the irascible Ernesto Lemos, Cesar Melito Martins, Michael Montesano, Ong Yanchun, Charlie Scheiner, Tomé Jeronimo de Sousa, Jill Steinberg, and Titi Supardi. Afonso Lai, Rui Pina, and Andre de Sousa all graciously provided information and allowed me to reproduce family photographs.

Unless otherwise noted, all interviews cited in this work were conducted by the author. Many of these were casual conversations, though in some cases a tape recorder was used and transcripts were made later. In a few cases Abel dos Santos assisted with translations from the Tokodede language. Interviews are cited by date and place (by hamlet, village, and subdistrict).

Archival material for this book was obtained from a number of sources. I would like to thank Marie McCloud and her staff at the Arquivo Histórico Macau for their assistance during two visits. The staff at the Arquivo Histórico Ultramarino in Lisbon kindly assisted with documents as well. Henk Schulte Nordholt made it possible to spend two wonderful months in Leiden at KITLV, where additional material was obtained while I was supposed to be working on another project. Hans Hägerdal generously shared his archival notes on Maubara and, unbeknownst to him, provided the impetus for actually completing the manuscript. Nandini Chaturvedula 
assisted with translations of a number of nineteenth-century Portuguese documents. Jan van der Putten kindly translated the Dutch letter of I759 renewing Maubara's allegiance to the VOC. Mrs. Lee Li Keng kindly produced the maps.

The family trees in the appendix were compiled from both oral interviews and written sources. Due to the need to fit each family on a single page, the individuals listed and information provided represent only part of what is known. The sources, too numerous to cite without overwhelming the presentation, have been omitted, but most can be found in the endnotes to the main text.

A number of people provided feedback on parts or all of the manuscript. Judith Bovensiepen, who loves a good mystery, has been my favorite critic throughout. Hilmar Farid helped me to think about how to write both against and for a nationalist historiography. Jamie Davidson did his best to keep me from taking on other commitments, sound advice that I foolishly ignored. My parents, Carol and Michael Kammen, read drafts of the manuscript and suggested a host of comparative references, only some of which have made it into the current volume. My wife has patiently put up with this project for far too long, for which I am extremely grateful, and my son happily knows nothing whatsoever about it. 



\title{
NOTE ON PLACE NAMES, PERSONAL NAMES, AND SPELLING
}

\begin{abstract}
$\mathrm{W}_{\mathrm{h}}$
hat place names signify in East Timor has changed significantly over time. For the eighteenth century, place names typically referred to polities (what the Portuguese called "kingdoms" and the Dutch East India Company called negery or rijken) or subpolities (which the Europeans assumed to be "vassals" of the kingdoms). In the nineteenth-century archival record, smaller settlements appear, usually referred to by the Portuguese as povoação or aldeia, which are translated in this work as hamlets. In I9O3, the Portuguese established two "jurisdictions" below the kingdom (Guguleur and Maubara Tassi), under which there were newly created village administrative units (suco) and numerous hamlets (aldeia). The Indonesian regime directly adopted the Portuguese administrative units, with the former kingdoms and Portuguese administrative posto becoming subdistricts (kecamatan), the suco becoming Indonesian-style desa, and the aldeia becoming dusun.
\end{abstract}

The spelling of place names has varied over time. The capital city thus appears as Dili, Dilly, Timor-Dilly, and now again simply Dili. I have used the standard Dili, except in quotations from primary sources. Although by no means uniform during any given period, the names of the kingdom/ subdistrict and the seven village-level units that eventually emerged are spelled variously.

Personal names are equally complicated. The people of Maubara have names from the Tokodede language. As in a number of other languages spoken in East Timor, Mau signifies a male, Bui a female. Beginning in the early eighteenth century, leading figures in Maubara adopted or were given Portuguese names, and in the late nineteenth century, when a Catholic priest first became a full-time resident in Maubara, the use of Portuguese names 
(given at the time of baptism) slowly became more common. Many people were given the surname of a godfather (often the local priest or a patron), so one cannot assume that individuals with the same last name are in fact related. It is also the case that children often do not have the same surname as their parents or their siblings. Finally, prominent individuals could be referred to by their Tokodede name, a rank or title, as well as a Portuguese name, often creating confusion and at times some uncertainty. Archival sources commonly spell personal names in ways that differ from current spelling, so every effort has been made to indicate where names that are spelled differently in fact refer to the same individual.

Terms listed in the glossary are identified by language: T. = Tetum; M. = Malay; D. = Dutch; P. = Portuguese; I. = Indonesian. Some terms, such as rei de pomali, involve combinations of Tetum and Portuguese words.

The various names by which East Timor has been known present a final problem: in the nineteenth century the Portuguese colonial possession was known as Timor Português (Portuguese Timor); when Fretilin declared independence in November 1975, they named their state República Democrática de Timor-Leste (Democratic Republic of East Timor); in 1976, when Indonesia annexed the territory, the province was called Timor Timur (East Timor); and when independence was restored in 2002, the official name reverted to República Democrática de Timor-Leste, and in conversation is simply called Timor-Leste. Throughout the book I employ the name appropriate at the time, though in places (particularly the introduction) the generic term East Timor is used.

Throughout this book I have standardized spellings, while remaining as faithful as possible to the preference of the individual and the integrity of the sources. Portuguese accents are used throughout, regardless of whether they appear in the original source or are used by living individuals in daily practice. 


\section{GLOSSARY AND ABBREVIATIONS}

$\begin{array}{ll}\text { AHM } & \text { Arquivo Histórico Macau (Historical Archive of Macau) } \\ \text { AHU } & \text { Arquivo Histórico Ultramarino (Historical Archive of } \\ & \text { the Overseas) } \\ \text { aldeia (P.) } & \text { hamlet } \\ \text { Apodeti } & \text { Assosiação Popular Democrática Timorense (Timorese } \\ & \text { Popular Democratic Association), established 27 May } \\ & \text { I975 } \\ \text { ASDT } & \text { Assosiação Social Democrática Timor (Timor Social } \\ \text { avo (T.) } & \text { Democratic Association), established 20 May I975 } \\ \text { BMP (I.) } & \text { Besi Merah Putih (Red and White Iron militia), in } \\ \text { BODAT } & \text { Liquica district } \\ \text { Boletim Official do Districto Autonomo de Timor (colonial } \\ \text { gazette) } \\ \text { Boletim Official do Governo da Provincia de Macau e Timor } \\ \text { deportado (P.) } \\ \text { (colonial gazette) } \\ \text { Boletim da Provincia de Macau e Timor (colonial gazette) } \\ \text { callades (M., P.) }\end{array}$




\begin{tabular}{|c|c|}
\hline desa (I.) & village \\
\hline Dom (P.) & Lord, Sir \\
\hline Dona (P.) & Lady \\
\hline Estado Novo (P.) & $\begin{array}{l}\text { New State; name of the quasi-fascist Salazar regime in } \\
\text { Portugal }\end{array}$ \\
\hline Falintil (P.) & $\begin{array}{l}\text { Forças Armadas de Libertação de Timor-Leste (Armed } \\
\text { Forces for the National Liberation of East Timor) }\end{array}$ \\
\hline finta (P.) & annual tribute \\
\hline Fretilin & $\begin{array}{l}\text { Frente Revolucionária do Timor-Leste Independente } \\
\text { (Revolutionary Front for an Independent East Timor), } \\
\text { established } 20 \text { May I974 }\end{array}$ \\
\hline Hakka & dialect group from China \\
\hline ikat (M., T.) & double-woven cloth \\
\hline Interfet & International Force for East Timor \\
\hline Kopassus (I.) & $\begin{array}{l}\text { Komando Pasukan Khusus (Special Forces Command, } \\
\text { in Indonesian Army) }\end{array}$ \\
\hline Larantuqueiro & $\begin{array}{l}\text { Portuguese term for the mestizo and Catholicized } \\
\text { community that developed around the Portuguese } \\
\text { base on Solor and Larantuca, and later Lifau; referred } \\
\text { to by the Dutch as "black Portuguese" }\end{array}$ \\
\hline lia nain $(\mathrm{T})$. & ritual speaker \\
\hline lisan (T.) & tradition, custom \\
\hline liurai (T.) & lit. lord of the land; indigenous ruler \\
\hline lulik (T.) & taboo, sacred \\
\hline malae (T.) & foreigner, usually referring to Europeans \\
\hline mardijker (M.) & freeman \\
\hline morador(es) (P.) & second-line military force \\
\hline mortel (T.) & glass or coral beads \\
\hline PIDE & $\begin{array}{l}\text { Polícia Internacional e de Defesa do Estado (Interna- } \\
\text { tional and State Defense Police), part of the Salazar- } \\
\text { Caetano regime }\end{array}$ \\
\hline pomali (T.) & taboo, sacred \\
\hline posto (P.) & subdistrict administrative unit \\
\hline povoacão (P.) & settlement, hamlet \\
\hline presidio $(\mathrm{P})$. & fort \\
\hline principal (P.) & member of the ruling or royal family; noble \\
\hline
\end{tabular}




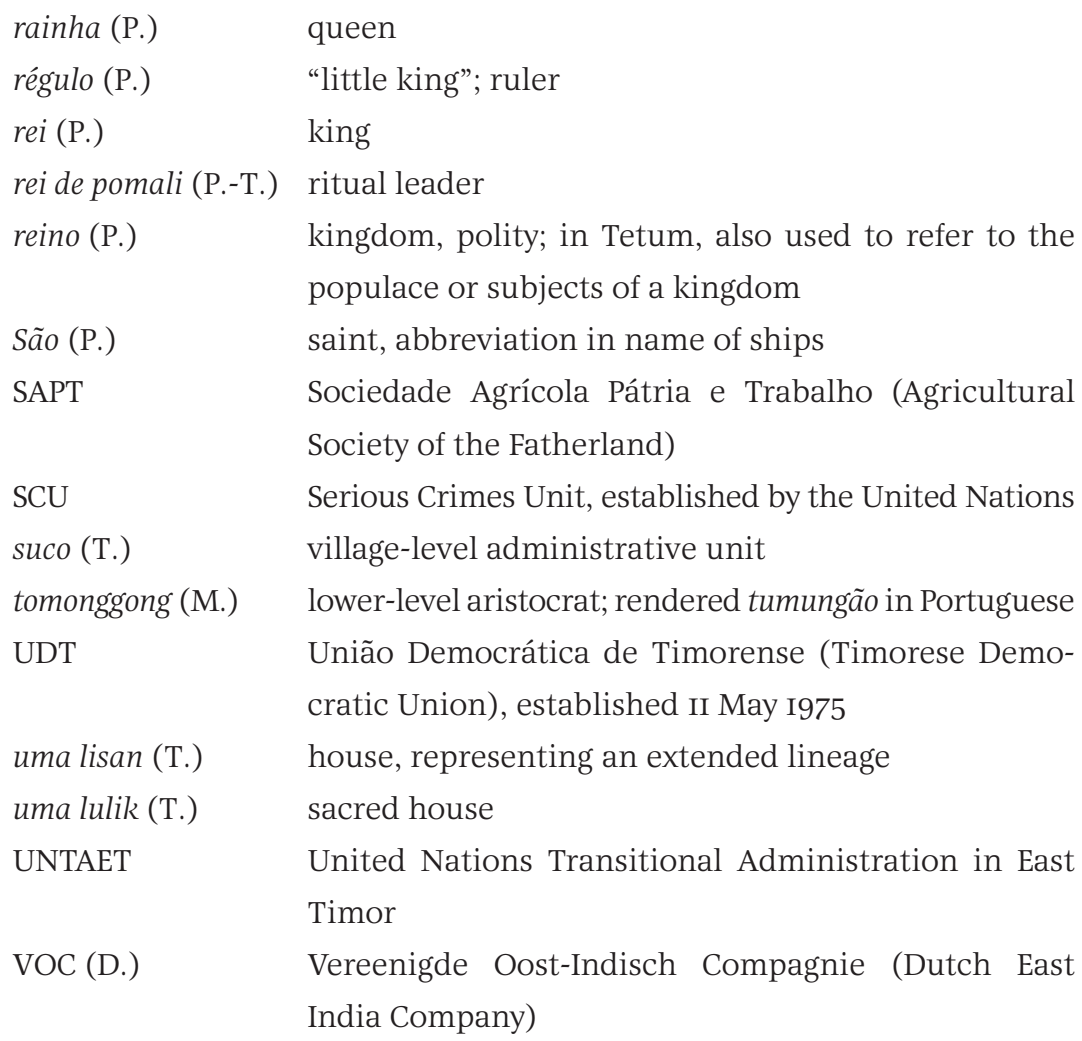





\section{Three Centuries of}

Conflict in East Timor 



\section{Introduction}

\section{Situating Recurrent Mass Violence}

\footnotetext{
$\mathrm{O}_{1}$ n 8 March 1999, about eighty members of the pro-Indonesian Red and White Iron militia surrounded the home of a sixty-year-old man named Mau Kuru in the village of Guguleur, near the peak of Mount Maubara in East Timor. As the militiamen mobbed the simple sitting area in front of the house, screaming threats and brandishing an assortment of weapons, Mau Kuru tried to shield his wife, Bui Krimi. One of the militia members lunged forward and thrust a spear into Mau Kuru's side, causing him to fall to the hard-packed dirt floor. The militia members then dragged Mau Kuru up the slope to the narrow asphalt road, where they hacked him to death with machetes. After the militia had left the area, frightened relatives hastily dug a shallow grave near the house and laid the family patriarch to rest. A few days later someone noticed that village dogs had dug up the grave and dragged the corpse away. Relatives retrieved the remains and reburied them. A week later, however, one of Mau Kuru's nieces was shocked to see that dogs had again unearthed the grave and carried off body parts. Another search was launched and most of the body was found, but Mau Kuru's head was missing. The remains were reburied.

Mau Kuru was the first person murdered in the subdistrict of Maubara during the nine-month campaign of violence waged by the Indonesian military and locally recruited militias leading up to the UN-sponsored referendum on independence from Indonesian rule. Why did the militia in Maubara murder Mau Kuru? The obvious answer is because he opposed the Indonesian occupation and could be expected to vote for independence in
} 
the referendum. This answer is technically correct but grossly simplistic. Most people in Maubara opposed the occupation and voted for independence in August 1999. So we must rephrase the question. Why, of all the people in his hamlet, his village, and the entire subdistrict of Maubara who supported independence, was Mau Kuru singled out? The answer to this question might also appear to be straightforward: the militia targeted Mau Kuru because he was a respected leader in his community who supported independence and could be expected to influence others in the vote. This explanation is also correct but assumes too much. Mau Kuru was indeed respected in a few hamlets near the top of the mountain, but he was not a leader of local resistance activities and was not in contact with national leaders in the capital city, commanders of the armed resistance in the mountains, or influential figures in the overseas diaspora. Mau Kuru was an illiterate man who eked out a living growing corn, cassava, and coffee.

Mau Kuru's murder was hardly without precedent in the recent history of Maubara. Twenty-four years earlier a triple murder was committed in the hamlet of Lautekas, just a few miles from Mau Kuru's home. Irregular forces operating under the command of the Revolutionary Front for the Liberation of East Timor (Frente Revolucionária do Timor-Leste Independente, abbreviated Fretilin) had routed the last positions held by the rival Timorese Democratic Union (União Democrática de Timorense, abbreviated UDT) in the town of Maubara on I5 September 1975. Fretilin leaders then sent patrols to scour the mountain for remaining UDT supporters. One of these patrols climbed the dirt track from the coast to the hamlet of Caicasa and from there to the home of the Sanches family, a mixed Portuguese-Timorese family that owned a large coffee plantation and supported UDT. Most of the family members were in Dili at the time, but three sons-aged thirty-one, nineteen, and eighteen-remained on the estate. The Fretilin patrol found the young men hiding in the undergrowth not far from the family house and executed them on the spot. The brothers may not have been the first people killed in Maubara during the interparty conflict in 1975, but the family was prominent and this was the most notorious murder in the region at the time.

Again, we must ask, why were three young men murdered? They did not pose a threat to the patrol. The most obvious answer is that the Sanches brothers were killed because of their family's political affiliation. But as 
in the case of Mau Kuru, this answer is far from satisfying: it assumes that local events fit neatly into national narratives. The commander who gave the order and most of his men were from elsewhere in East Timor, and so did not know the three young men personally. But there were plenty of people in the surrounding hamlets that harbored grudges against the family, and local informants may have provided information that contributed to the commander's decision to kill the brothers. The grudges against the Sanches family did not stem from political affiliation alone, however. They had to do with land rights, forced labor, and abusive treatment of women, some of which were relatively recent but others that went back much further in time and were intertwined with local claims to precedence, hostility to Portuguese settlers, and long-standing opposition to colonial rule.

What is most striking about the murder of the Sanches brothers in 1975 and Mau Kuru in 1999 is the ease with which observers have assumed that local events are fully intelligible simply and matter-of-factly in terms of national conflicts and narratives. And yet, as some of the finest recent studies of mass political violence have demonstrated, this is a dubious assumption.

These paired murders occurred within much larger episodes of mass violence that engulfed all of East Timor in 1975 and 1999. The conflict in 1975 between the recently formed political parties is often referred to as a civil war, though in its brevity (mid-August until mid-September), limited geographic scope (primarily the districts closest to the capital, Dili), and relatively low number of fatalities (estimates range from one to two thousand people) it might be better understood as an attempted seizure of power by the Timorese Democratic Union and a swift and successful counteraction by the rival nationalist party, Fretilin. The violence in 1999, by contrast, involved the Indonesian military and systematically organized civilian militias employing terror to intimidate the population to vote in favor of continued integration with the Republic of Indonesia, and when that failed a final, vengeful spree of violence in which several hundred people were killed, a large portion of all physical infrastructure was destroyed, and several hundred thousand people fled or were forcibly deported to Indonesian West Timor. Between these episodes lay twentyfour terrible years of war and military occupation that involved systematic 
human rights abuses and cost the lives of over one hundred thousand East Timorese. ${ }^{1}$

\section{Mass Violence and the Nation}

The recurrence of mass violence is central to the telling of East Timor's history and looms-at times explicitly, at times unspoken-over much of the analysis of East Timorese society and politics since the restoration of the country's independence in 2002. The violent past and the much heralded "postconflict" present are portrayed as subjugation and liberation, injustice and redemption, even as cause and effect. For if there is one point on which all observers and scholars agree it is that for more than three centuries the people of East Timor have been the victims of recurrent mass political violence. That past, many observers worry, continues to haunt the present. But while we know many of the details of individual episodes and even entire periods of violence, little attention has been paid to the relationship between the recurrence of mass violence over long periods and the subjectivities of the people who were the targets, and at times, too, the perpetrators, of violence.

Historians of East Timor typically have treated mass violence within the framework of national narratives. The major Portuguese-language histories of East Timor are constructed around the efforts of brave governors and military officers to secure the territory and civilize its people in the name of Crown and empire. ${ }^{2}$ Reflecting the colonial archival sources on which they are based, the authors of these histories have depicted Timorese peoples and cultures as being inherently prone to violence. Writing in the I86os, for example, Governor Affonso de Castro commented that "rebellions in Timor have taken place one after another, such that one can say revolt is the normal state of affairs and peace the exception.” The assumption that Timorese peoples were prone to commit acts of violence justified the myriad campaigns of pacification, drove colonial state building, and provided occasion for defense of national pride traced from the time of Henry the Navigator. Beginning in the I99os, a new generation of scholars sought to deepen our understanding of East Timorese resistance to Portuguese colonial rule by reexamining the many uprisings and rebellions against the colonial state from below. Reading against 
the grain of the colonial archives, these authors explored the dynamics of indigenous resistance and, where possible, shed light on the meaning that acts of resistance held for Timorese people and communities in the past. ${ }^{4}$ Although their findings differ in some respects, there is a general consensus that resistance to Portuguese colonial rule revealed the seeds of proto-nationalism that eventually blossomed into full view in the I970s.

The Indonesian invasion of Portuguese Timor in 1975 and the brutal occupation that followed prompted an outpouring of both activist and scholarly writing. Outraged by the illegality of the Indonesian annexation and global indifference to the widespread suffering and abuse of human rights, authors sought to bring the horrors of the invasion and occupation to world attention. With the territory all but closed to foreigners, however, sources of information were limited. Nevertheless, researchers produced valuable studies on the aborted process of decolonization from Portugal in 1974-1975 and the Indonesian invasion in late $1975,{ }^{5}$ the war and military occupation, ${ }^{6}$ the remarkable resilience of the East Timorese resistance and deepening of nationalist sentiment, ${ }^{7}$ the violation of human rights, ${ }^{8}$ and the final denouement in 1998-1999. ${ }^{9}$

Alongside this largely foreign scholarship, pioneering East Timorese nationalists responded to the invasion and occupation by standing the old imperial history on its head and celebrated East Timorese resistance to foreign incursions and colonial repression. During the dark years of the Indonesian occupation, East Timor's most prominent diplomat in exile, José Ramos-Horta, wrote a book titled Funu: The Unfinished Saga of East Timor. In calling the book Funu, the Tetum word for "war" or "warfare," Ramos-Horta drew a direct line of descent from the many rebellions against Portuguese colonial rule to Japanese military brutality during World War II and resistance to the Indonesian occupation. ${ }^{10}$ Other East Timorese authors exhibited greater caution in assuming that indigenous resistance was premised on unity and necessarily presaged a national identity. Adopting a rough and ready Marxist schema to challenge the old imperial historiography, in I975 the young Abilio Araujo identified the collaboration of East Timorese elites with the Portuguese colonial regime both as a source of localized resistance and a reason for its failure to produce a united challenge. ${ }^{11}$ Perhaps the most remarkable statement of the relationship between colonial (and neocolonial) oppression and East Timorese identity is found in the 
writings of José Alexandre "Kay Rala Xanana" Gusmão, who assumed leadership of the armed resistance in the early I980s. In a written address to the nation's youth in 1986, Gusmão argued simultaneously that East Timorese identity was timeless but that its full expression had been forestalled by colonial pacification:

The historical identity of East Timor dates back to long before the arrival of the Portuguese. If it had not been for the intrusion of Portuguese colonialism, the people of East Timor would have followed their own path; they would have created a socio-political structure defined by the essence of one people and one nation. With the arrival of the colonists, this march was halted because the necessity of exploring [sic, exploiting] our wealth caused a war of pacification that put a stop to the struggles between the diverse kingdoms, each one wanting to take a position of ascendancy and domination over the others. The ascendancy of one of these tribes would have determined the formation of a great kingdom-the embryo of the Maubere Homeland!12

Despite differences in the periods addressed, perspectives, and analytical approaches, the old imperial histories, the revisionist scholarship, nationalist accounts, and studies of the Indonesian occupation have all made recurrent mass violence the leitmotif of East Timor's past. This tendency is illustrated in a recent essay by Frédéric Durand, who writes, "The fierce desire for independence of the East Timorese kingdoms . . . manifested itself with the very first contacts with the Portuguese and endured through the struggle against Indonesian occupation.” ${ }^{13}$

The leitmotif of violence is not restricted to the study of East Timor's past; it has also informed scholarship on East Timorese politics and society since the 1999 referendum, in which the East Timorese people won their freedom from Indonesian rule, and the restoration of independence in May 2002. The flood of new scholarship on contemporary East Timor has developed along three quite different trajectories. One strand of work, closely associated with the transitional justice movement, has focused on the need to document and address the legacies of past violence. A second strand, primarily associated with political reconstruction, has viewed the mass violence and physical devastation of 1999 as marking a complete 
break with the past, and hence a moment of opportunity and hope. A third branch of analysis has highlighted the emergence of violence since the restoration of independence, initially in the form of localized riots and security disturbances, then in 2006 involving armed clashes between the country's new security forces and communal violence between easterners and westerners, and in early 2008 with the alleged attempts to assassinate President José Ramos-Horta and Prime Minister Xanana Gusmão. While the first two strands have viewed 1999 as marking a break with past violence, the conflicts in 2006-2008 prompted observers (including some East Timorese politicians) to resort to terms such as "postconflict conflict," “cultures of violence," and even "state failure." Violence was by no means a thing of the past.

While there is no denying that the territory once known as Timor Português, then the annexed Indonesian province of Timor Timur, and today as independent Timor-Leste has a long history of mass violence, the subordination of episodic and recurrent violence to a single national narrative is problematic. East Timorese nationalism, almost all authors agree, is of recent origin, first emerging in the early I970s and then spreading and deepening during the course of the Indonesian occupation. ${ }^{14}$ It is therefore necessary to avoid conflating violence-whether that committed by foreign invaders, indigenous resistance to foreigners, or fighting between local actors-with nationalism. Historically, there was no steady, inexorable movement from the many rebellions against the Portuguese governors in the eighteenth century and again during the second half of the nineteenth century through the last Great Rebellion of I9IO-I9I2, the Japanese military occupation, ${ }^{15}$ the Viqueque Rebellion in I959, the brief period of conflict between the newly formed east Timorese political parties in August-September 1975, and the Indonesian invasion and annexation (I975-I999). The propagation of narratives about centuries of struggle by the East Timorese nation (or nation-in-becoming) against foreign powers may reveal something about the construction of historical knowledge, the power of mass media, and the educational system since I999, but it is generally a very poor basis for understanding historical processes and their ongoing legacies today.

Despite the centrality of violence in East Timor's history and the telling of that history, there are surprisingly few studies of the dynamics and 
impact of recurrent mass (as well as small-scale) violence in individual localities. Of the few such works that do address violence across time, one of the finest is Janet Gunter's study of violence during the twentieth century in the subdistricts on the eastern and southern slopes of Mount Matebian. Gunter traces the lineages of contestation and violence from the onset of direct colonial rule at the turn of the century through the Japanese occupation to its culmination in the 1959 uprising and Portuguese pacification campaigns. ${ }^{16}$ Another notable work is Ernest Chamberlain's study of Iliomar, located in the easternmost district of East Timor and an important site of resistance activity throughout the Indonesian occupation. ${ }^{17}$ Even in these important works, however, the time frame is necessarily restricted (Gunter covering five decades, Chamberlain twenty-four years) and the focus is on explaining the causes and dynamics of violence, not the implications of its recurrence over time.

There are rather obvious reasons for the lacuna. The study of local cultures and histories in East Timor has been the preserve of anthropologists, whose concerns have generally focused on understanding social structures, documenting cultural practices, and exploring meaning in the ethnographic present. The oral sources on which most anthropological works rely typically highlight origin stories and genealogies, cultural norms and practices, but often lack temporal markers and sequential orderings of events. A second factor inhibiting local studies of violence is the availability of archival sources ${ }^{18}$ Colonial documentation is typically skewed by the interests of those who produced them and hence provides little access to the worldviews and thoughts of Timorese actors who experienced or subsequently recounted episodes of violence. Furthermore, individual polities typically appear only episodically when colonial or neocolonial states observed and responded to some sort of disturbance, and it is rarely possible to trace events in a single polity or kingdom across time.

Nevertheless, there are localities in East Timor for which it is possible to reconstruct the history of mass violence over long periods. One such place is Maubara, where the Sanches brothers were murdered during the armed conflict between the newly formed East Timorese political parties in 1975 and where Mau Kuru was killed by the pro-Jakarta militias in 1999. Located on the north coast between the capital city Dili and the border with (Dutch and now Indonesian) West Timor, in the eighteenth century 
Maubara was an important kingdom; in the nineteenth century it was a center of indigenous coffee production; in the early twentieth century it was a bastion of the colonial plantation economy; and today it is a sleepy subdistrict with a population of about fifteen thousand people. Drawing on a combination of archival and oral sources, this book reconstructs the history of recurrent mass violence in Maubara over three centuries (I7I220I2). This historical reconstruction enables exploration of the interplay between changing local subjectivities, on the one hand, and the production and impact of mass violence, on the other.

\section{Recurrent Mass Violence}

There are surprisingly few works in the literature on riots, communal conflicts, civil war, and genocide that address the problem of the recurrence of violence in the same location and involving the same people over long periods. However, regardless of the differences that separate cultural, institutional, and social-ecology approaches to the study of mass violence, there is general agreement among political scientists and sociologists that mass political violence increases the likelihood of subsequent episodes of violence. This is most often and most powerfully expressed in the idea that "violence begets violence" and the ubiquitous use of the phrase "cycles of violence." This view is not limited to single episodes (for which it is selfevident that one possible response to a violent attack is self-defense and one means of escaping tyranny is to take up arms), but is also found in the context of recurrent violence over considerable periods. In the words of Stanley Tambiah, "intermittent ethnic riots form a series, with antecedent riots influencing the unfolding of subsequent ones." 19

Existing scholarship suggests two major approaches to recurrent mass violence. ${ }^{20}$ Perhaps the most common of these is the view that the memory of past conflict fuels and shapes the dynamics of subsequent episodes. In an influential book on ethnic riots, for example, Donald Horowitz writes, "It must be assumed that important episodes of mass violence form part of the leitmotiv of memory. When episodes of violence form a closely ordered sequence, as in so many north Indian cities, then the recollections and the consequences—structural and attitudinal—of the earlier episodes form part of the machinery in place for the later ones." ${ }^{21}$ Similarly, in a study 
of genocide in Rwanda, Peter Uvin argues that "once a serious episode of violent conflict occurs, it leaves a persistent residue in people's memories and attitudes." ${ }^{22}$ Memory is also a core element in William Rowe's engrossing study of a single county in China over the course of seven centuries, in which he argues that "collective memory, historical consciousness, and other routinized cultural practices played a critical role" in the recurrence of violence. ${ }^{23}$

A second approach, often favored by political scientists, focuses on the role of institutions, particularly the state and state building. This may involve territorial expansion, the recruitment of men into the armed forces, suppression of rebellion, revenue collection, and the establishment of a host of institutions that expand the capacity and the reach of the state. Conversely, the failure of state institutions may also fuel violent conflict. Authors such as Mahmood Mamdami in his work on genocide in Rwanda and Jacques Bertrand in his study of violence in Indonesia appeal to the role of institutions to dispel the notion that violence was the unavoidable result of primordial attachments or cultural traits. ${ }^{24}$ The focus on state institutions has also been driven by an interest in establishing accountability for human rights abuses. An institutional approach may appear to be particularly attractive in cases such as East Timor where external powers-in this case the overseas Portuguese Empire, the Japanese military, and the Indonesian regime of occupation-is so clearly the macrolevel cause of mass violence.

However, the role of memory and states becomes problematic when one moves from discrete periods-say two or three generations or the duration of a particular regime-to the longue durée, as is the case in this book on Maubara. Rowe's study of Macheng county over seven centuries is made possible by China's long history of literacy and the exceptionally rich archival sources. As Rowe acknowledges, "county gazetteers, lineage genealogies, and other written documents engaged in an ongoing negotiation with oral traditions, and with each other, over understandings of the shared local past." ${ }^{25}$ But what of places without written traditions or, as in Maubara, where the few documents became sacred objects rather than living texts? Anthropologists of Timor have made excellent use of oral traditions to understand the ethnographic present, but these traditions do not provide direct access to what people in the past knew or the meanings they 
attached to events. Memories in the past remain elusively out of reach. Related problems arise when we turn to the role of states in the recurrence of mass violence in a place like Timor over several centuries. For people who lack the extensive written sources found in Macheng are likely to be people without (or just beyond) centralized states with fixed bureaucratic structures, administrative capacity, and record keeping. A focus on states may provide critical insights into the causes of mass violence but risks assuming the primacy of national interests and identities, so is ill suited to address the question of how recurrent violence is experienced or shapes popular responses to subsequent conflict.

To make better sense of the recurrence of mass violence in Maubara over several centuries, it is helpful to revisit the assumptions that have informed much historical writing about Timor. The common view that violence in East Timor was caused (and more often than not also produced) by outsiders obscures the great variation across time and space and relegates the indigenous population to objects or, only slightly better, renders them as brave resisters. In place of this, it is helpful to pose this question: who produced violence? This allows for a wide spectrum of possibilities, with violence produced by local (indigenous) actors at one extreme and violence produced by external powers (representatives of the Portuguese Crown and the Dutch East India Company, Makassarese traders/raiders from Sulawesi, the Japanese military, the Indonesian state) at the other extreme. Between these poles violence might be produced by competing Timorese polities, by regional alliances, or by indigenous actors loyal to foreign powers. Similar modifications can be made to the common assumption that indigenous hostility to foreign incursions and occupation is the story of one nation over time, or, in slightly more nuanced form, that early resistance produced proto- and then full-blown nationalism. Instead, it is fruitful to expand the realm of possibilities by asking how local subjectivities in Maubara have changed over time.

The nexus between the production of violence and local subjectivities is necessarily dynamic. This is most commonly conceptualized in terms of two possible processes: nationalization and parochialization. In a pioneering work on the coming of the US Civil War, for example, Edward Ayers and Anne Rubin studied two communities located on either side of the MasonDixon line in the Shenandoah Valley. They show that these communities 
were deeply divided on the question of slavery up until I860, but with the outbreak of war each quickly coalesced behind the competing sectional positions in which the war was framed. ${ }^{26}$ But such nationalization of local subjectivities is by no means inevitable. Elsewhere scholars highlight exactly the opposite dynamic: circumstances in which mass violence produced at the national (or simply supralocal) level may provide opportunities for local actors to pursue purely local differences. In the words of Stathis Kalyvas, "local politics are not just (or primarily) the local reflection of national politics but that, instead, party labels are appropriated within the village to serve ends that often have only local significance and little or nothing to do with the parties as national institutions in a process that has been described as 'parochialization."' 27 Drawing on these observations, Tambiah proposes that ethnic riots in South Asia can be fruitfully examined in terms of both nationalization (whereby localized violence becomes a symbol in the context of broader conflicts) and parochialization (whereby national conflicts are reverberated downward and endowed with local specificities). ${ }^{28}$

Useful as this framework may appear, there is a danger in assuming that nationalization and parochialization are the only possibilities. Between these lie a variety of possible ways that subjectivities may be expressed. Localized violence may result in the intensification of the factional differences that drove it without any alignment with larger subjectivities, but it may also drive actors to seek external allies and thereby develop supralocal identifications. Writing on seventeenth- and eighteenth-century Timor, for example, Hans Hägerdal observes that "in the Timorese world of perpetual small-scale violence, what people desperately needed was support and security; in the best of situations this is what the covetous foreigners could offer." ${ }^{29}$ When violence is produced from above, as was often the case with colonial campaigns of pacification, responses may also vary according to the nature of local subjectivities. Where there is strong local unity the response might be a defensive and inward-looking localism, but where dense webs of marriage and other forms of alliance with neighboring peoples and polities exist violence might produce a slightly broader provincialism. Equally possible, of course, are scenarios in which externally produced violence acts on localities characterized by internal factionalism but without strong supralocal attachments, producing parochialization. 
Where local factionalism maps onto supralocal attachments and framings, the coming of violence may result in religious sectarianism, ethnic communalism, political partisanship, and even, under the right conditions, nationalization.

These are by no means the only possible combinations, but for present purposes they illustrate a spectrum of possibilities. The challenge, therefore, is to explore how the production of violence on the one hand and local subjectivities on the other have shaped and reshaped one another, and to examine when and why shifts have occurred. The history of violence in Maubara reveals significant variation along both dimensions. During the eighteenth century, as we will see, a Portuguese military force passing through the Kingdom of Maubara on its way to pacify a rebellion in the interior brought local factionalism to the fore; a decade later the astute dynastic rulers of Maubara purchased their release from Portuguese claims and sought protection from the Dutch East India Company; during the second half of the century repeated attacks by the Portuguese and their indigenous allies simultaneously served to deepen Maubara's alliance with the Dutch and strengthened localist sentiment; but as Dutch engagement with Maubara waned in the early nineteenth century there was a return to internal factionalism and violent conflict. During the century from I850 until I950, the production of violence and local subjectivities again shifted dramatically, first involving parochial responses to the new Portuguese colonial masters, then open resistance expressed as a combination of localism and internationalism, and finally a retreat into a defensive localism and a halfhearted attempt to reassert factional dynastic claims. The collapse of the Salazar-Caetano regime in Portugal in 1974 opened a new political world, but one that remained deeply colored by local attachments and history. We will see how the aborted process of decolonization in I974I975 produced partisan support for the newly awakened nationalist positions, how the Indonesian invasion and occupation fueled both localist claims alongside increasing nationalization of the populace, and how this eventually found full expression in the I999 referendum on independence.

Finally, it is worth pausing to situate these observations in relation to the broader literature on mass political violence. Unlike findings about urban riots in India or genocide in the Caucasus, Central Africa, or the former Yugoslavia, for which sectarianism and communalism (at times 
mapping on to provincialism) are critical expressions, the long history of violence in Maubara exhibits swings between the extreme positions of localism, factionalism, and parochialization, on the one hand, and partisanship and nationalism on the other. Furthermore, the analysis that follows demonstrates that expressions of localism and supralocal attachments in Maubara were compatible, and indeed often mutually reinforcing. This history provides a powerful reminder that subjectivities do not develop in a linear progression from traditional local worldviews to modern nationalism, and so cautions against simplistic assumptions about nationalization and ready acceptance of national narratives.

\section{Postconflict Fantasies and Local Experiences}

The murder of Mau Kuru on 8 March 1999 signified a critical escalation of activity by the Red and White Iron militia and the onset of six months of terror and violence in Maubara. And Maubara was not alone. By the time Mau Kuru was murdered, militias mobilized and directed by the Indonesian Army were operating in every district in East Timor. Paralleling the structure of their patrons, the district-level militias were organized into a loose umbrella structure called the Integration Fighters Force (Pasukan Pejuang Integrasi) that, just three days after Mau Kuru was killed, began discussing plans to begin Operation Clean Sweep with the aim of capturing and killing important proindependence leaders. ${ }^{30}$ Despite months of intense intimidation and bloody attacks by the military-backed militias, the UN-sponsored referendum was held on 30 August I999, and the result, announced four days later, was overwhelming: 78.5 percent of eligible voters cast ballots rejecting Indonesia's offer of broad autonomy. This was, in other words, a vote for independence. In response to the announcement, the Indonesian military and the militias rampaged, killing hundreds of people and displacing (forcibly or otherwise) two hundred thousand more from their homes.

The arrival of an international peacekeeping force and the establishment of the United Nations Transitional Administration in East Timor (UNTAET) brought the promise of release from the Indonesian occupation and an end to the territory's long history of recurrent mass violence. As people returned to destroyed homes and devastated towns, and 
as members of the Timorese Diaspora began to trickle back to Dili after decades abroad, expectations were extraordinarily high. Reflecting the ebullient mood, UNTAET administrator Sergio Vieira de Mello told reporters in early 2000 that East Timor was "a laboratory case where we can transform utopia into reality." 31

The events of 1999-tragic in their cost in life and suffering but triumphal in liberation-are commonly depicted as marking a critical break in East Timor's story. This is most certainly correct. The terrible twenty-fouryear occupation was over and self-determination had been won. This was, in the words of longtime East Timor activist Noam Chomsky, "a remarkable testimony to what the human spirit can achieve in the face of overwhelming, indescribable odds, an achievement that should inspire hope as well as humility." ${ }^{32}$ At the same time, however, there has been an unfortunate tendency on the part of some observers to provide a caricatured depiction of the violent colonial and neocolonial past that had finally ended in I999 and the postconflict present and future thereafter. This depiction has been produced by and reinforced through three distinct lines of activity and enquiry.

The first of these, stemming in large part from the result of the referendum, is the romanticization of the East Timorese nation. It is often assumed that the overwhelming vote in favor of independence signified strong national unity—of intent, of shared identity, and of an envisioned future. This view was reinforced by the fact that the regime of occupation departed in toto and the militia leaders and the vast majority of their followers had also decamped to Indonesian West Timor or dispersed elsewhere in Indonesia. With the most apparent source of divisiveness and threat wholly removed, it was all too easy for journalists, officials in international organizations, and many scholars to romanticize national solidarity and celebrate the arrival of international initiatives packaged in the language of postconflict reconstruction and a peaceable future.

The notion that 1999 marked, or should mark, a wholesale break from the past lay at the heart of a second set of activities and discourse. The violent past, it was argued, was a danger that had to be contained. Crimes had been committed, rights had been violated, and grievances remained unaddressed. In the words of Richard Goldstone, who served as chief prosecutor for the International Tribunal on the Former Yugoslavia and Rwanda, 
"victims do not, indeed cannot, forget. And their unanswered calls for retribution develop into hate and invariably hate is directed collectively at the group from which the perpetrators come." ${ }^{33}$ The answer to this, scholars suggest, is that "we must remember what happened in order to keep it from happening again." ${ }^{34}$ In East Timor, these concerns prompted local activists and international actors to call for the application of the now standardized "transitional justice" toolkit: the pursuit of justice for those who had perpetrated human rights abuses and crimes against humanity; truth seeking in order to document past wrongs and to provide those who had suffered an opportunity to tell their stories; the promotion of reconciliation between victims and perpetrators through which communities could be made whole; and the memorialization of both heroes and victims. The legal remedy involved the establishment of a Serious Crimes Unit, under the office of the East Timor prosecutor general (though in reality run by the UN mission) and a hybrid tribunal, called the Special Panels for Serious Crimes, to try perpetrators. Parallel to this, a national Commission for Reception, Truth and Reconciliation (Commissão Acolhemente, Veridade e Reconciliação, CAVR) was established with the mandate to assist victims, document human rights abuses for the entire period from I974 until 1999, and promote reconciliation. ${ }^{35}$ These joint initiatives were intended to ensure that violence remained in the past. As Lia Kent rightly observes, the language of transitional justice is one of progression from irrationality, violence, and the violation of rights in the past to a present and future characterized by rationality, order, and respect for rights inherent in liberal regimes. ${ }^{36}$

Meanwhile, a third dynamic was playing out in the realm of state building and political reconstruction. The massive physical destruction and the withdrawal of the former regime of occupation meant that there was a complete absence of a state. It was in this context that the United Nations and other international actors came to view East Timor as a blank slate on which they were free to employ international best practice to construct entirely new political institutions. International best practice recognized that state building must be tailored to local conditions, histories, and cultural practices, but there is little evidence that this was ever taken very seriously. ${ }^{37}$ Instead, the lesson drawn from the referendum was that that East Timorese are rational actors who, under benevolent UN tutelage, 
would freely join political parties of their choosing and cast ballots in national elections based on what was in the best interest of the country as a whole.

Together, the romanticization of the nation, the application of transitional justice practices, and the construction of wholly new political institutions contributed to a discourse that contrasted the postconflict present (and future) against the violence of the Indonesian occupation. Reminiscent of the study of East Timor's violent past, the notion that East Timor had transitioned into a postconflict present implicitly subordinated local histories and experiences to a national narrative.

Both the transitional justice and blank slate theses quickly ran up against the complexity of recurrent past violence. Those concerned about addressing the legacies of violence committed in I999 were confronted with the problem that the perpetrators-both the Indonesian military and the prointegration militias-were no longer within the territorial jurisdiction of East Timor. For this reason CAVR focused much of its effort on truth-seeking and the promotion of reconciliation at the local level. While reconciliation aimed to address the immediate past, it quickly became apparent that antecedents mattered. It was not uncommon for deponents in the reconciliation exercises to insist on beginning their accounts well before the militia violence in 1999, often going back to the period of failed decolonization in 1974-I975. The legacies of the past were also raised by the incorporation of traditional conflict resolution mechanisms, which could result in local friction over who were the appropriate bearers of those traditions and what the traditions entailed.

The past also came to haunt the blank slate thesis. Despite statements about their commitment to justice, the United Nations and the major Western powers had no interest in seeing the establishment of an international tribunal for East Timor. And despite the best of intentions, the meager efforts to promote reconciliation among the national elite came to naught. Meanwhile, those engaged in state building soon encountered a related problem: deep-seated tensions between the East Timorese elite, much of which dated from the brief civil war of I975, led to the collapse of the National Council of Timorese Resistance (Conselho Nacional de Resistência Timorense, CNRT) that had presented a unified face in I999 and new jockeying for position in elections for the Constituent Assembly 
tasked with writing the new constitution. ${ }^{38}$ This was exacerbated by the mandate and interests of UNTAET, which was often unaware of the escalating political rivalries within East Timorese society. When tensions were recognized, the response was often to paper over them through a combination of procedural formalities and the ad hoc exclusion of Timorese actors from political discussions and policy making. ${ }^{39}$

The restoration of independence in May 2002 signified the victory of the nation in achieving its own, internationally recognized state. But the combination of scarce resources and intensifying political competition opened the way for the reemergence of violence. This first took the form of rumors about mysterious armed groups and localized riots in 2002 and 2003. In mid-2005 mass demonstrations led by the Catholic Church and encouraged by opposition political parties greatly exacerbated political tensions. These fault lines widened in 2006 when the issue of discrimination with the new military erupted into armed clashes within and between the security forces and spilled over into communal violence framed in terms of deep-seated hostility between people from the eastern districts, labeled firaku, and those from the western districts, termed called kaladi. The crisis (krizi), as it was called, resulted in the internal displacement of well over one hundred thousand people in Dili and lowlevel but ongoing neighborhood clashes. Despite the return of UN peacekeepers, over the next few years violence continued to haunt the country, first in the form of localized attacks in the wake of the 2007 national election and the following year in the alleged attempts to assassinate the president and prime minister, prompting the declaration of a state of emergency. The postconflict mirage had been shattered. UN officials, East Timorese politicians, and outside observers alike began to speak of "postconflict conflict" and a "failed state" and at times even resorted to the colonial era discourse of "cultures of violence."

Once again, scholars have generally treated these post-I999 developments from above as the story of national conflict over national institutions. In doing so, however, we run the risk of assuming the primacy of national identity and of misrepresenting the degree of change or continuity in attitudes toward central state power and political participation. Local responses to independence and new forms of conflict have been shaped by the interplay of particular histories, including (but by no means limited to) episodes 
of past violence; they have been expressed by parochial local allegiances and rivalries as well as by supralocal and national attachments; and they have involved ongoing claims on and in the name of history. The second aim of the book, therefore, is to relate the long history of recurrent mass violence in Maubara from the early eighteenth century until I999 to how the people of this subdistrict have responded to politics following the restoration of East Timor's independence. The book demonstrates that local patterns of alliance and rivalry have remained remarkably constant across time and continue to exert strong influences on the positions that individuals, extended families, and entire hamlets adopt. But that does not mean the people of Maubara are parochial country bumpkins or aloof traditionalists. Instead, local factionalism reinforced by centuries of conflict and periodic mass violence have mapped on to national commitments.

\section{Book Plan}

This book takes the murders of the Sanches brothers in I975 and Mau Kuru in I999 as points of departure for the investigation of recurrent violence across three centuries and the implications of this violence for how we study postconflict reconstruction. The historical narrative, which loosely follows Mau Kuru's family from the early eighteenth century until the present, draws on Portuguese, Dutch, and Indonesian archival materials as well more than one hundred oral interviews and informal conversations conducted in Maubara and elsewhere in Timor. These sources cross-fertilize one another in ways that allow us to reconstruct the dynamics of recurrent violence and illuminate the meanings of past violence and the challenges of independence in the present.

The first two chapters cover the century and a half between I7I2, when

the first identified ruler of Maubara appears in the historical records, and I859, when Maubara was part of a territorial exchange between the kingdoms of the Netherlands and Portugal. Chapter I situates Maubara at the nexus of long-distance maritime trade and coastal-hinterland exchange. It locates the first known ruler in terms of both origin stories and the foreign presence in the region. Chapter 2 turns to the century of alliance between the rulers of Maubara and the Dutch East India Company, which had a regional base in Kupang, at the western end of the island of Timor. 
The onerous demands made by the early Portuguese governors for tribute and the threat posed by Portugal's indigenous allies drove the rulers of Maubara to seek out alliance with the Dutch, ushering in a golden age of trade and diplomatic visits. The collapse of meaningful Dutch involvement in Maubara in the early nineteenth century triggered the intensification of local factionalism and eventually resulted in the fateful territorial trade completed in I859. Together, these chapters highlight the interaction between indigenous conceptions of power and alliance, on the one hand, and the outside projection and symbolic representation of a "kingdom" and "kingship," on the other.

The next three chapters consider the experience of recurrent violence under Portuguese rule from I859 until 1974. Chapter 3 traces the rivalries within the kingdom from the time of the territorial transfer until I887. During this period Maubara was wracked by robberies and murders, engaged in a brief "war" with a neighboring kingdom, and was the site of an open, albeit small-scale, rebellion and brutal Portuguese counteroperations. Chapter 4 examines the background to and the course of the ill-fated plot to oppose Portuguese rule and seek Dutch protection in 1893. Colonial authorities responded to the uprising by carrying out military operations that devastated at least half of all settlements in the kingdom and set the stage for the onset of direct colonial rule. Chapter 5 explores the dual transformation of political and economic relations in Maubara from the mid-I89os until the end of Portuguese colonial rule in the I970s, showing how the enormous increase in the coercive capacity of the colonial state not only alienated much of the populace from neotraditional rule but also severely restricted the possibilities for the emergence of new political imaginings.

The final two chapters cover the period from I974 until 20I2. The conventional approach to East Timorese history and politics has been to treat the Indonesian occupation (1975-1999) as a whole, and then treat all that has come after the 1999 referendum-UN tutelage from I9992002 and independence thereafter-as an entirely separate period. Veering away from this model, chapter 6 covers party politics in 1974-I975 and the long occupation from 1975 until 1998. It demonstrates that the sudden imposition of decolonization following the Carnation Revolution in Portugal and the brutal Indonesian invasion that followed set in motion 
concomitant processes of nationalization and parochialization in Maubara. The following chapter begins with the violence perpetrated by the Indonesian military and the local militia in I998-I999 and then traces efforts to address this violent past by examining the promise of justice, reconciliation initiatives, family rivalries, and electoral politics up to the 2012 elections. Paradoxically, the achievement of national liberation created the conditions for new expressions of long-standing local rivalries.

This book bridges the gap between the historical experience of largescale violence and the legacies of that past in the lives of people in one small place. On the most basic level this is an experiment in using a combination of thin archival sources and potentially endless oral interviews to reconstruct the history of violence in a small, far-flung place. For readers interested in the uses and limitations of both the archival record and oral sources, the book provides an argument that only by reading these sources against one another can we begin to historicize East Timor's past. On a second level the book makes the case for shifting our analytical frame from that of explaining why mass violence recurs to locating its recurrence within a matrix of how violence is produced and changing local subjectivities. Recurrent mass violence, I argue, does not produce a given outcome but rather becomes entwined with local understandings of the past, with local as well as supralocal allegiances and rivalries, and with attachments to the nation. Finally, the histories of Mau Kuru and the Sanches family illustrate that only by rescuing the microhistorical experience of recurrent mass violence from the nation can we better understand the legacies that the violent past has in present-day East Timor. 



\section{1}

\section{Contested Origins}

$\mathrm{V}$

iewed through the prism of East Timor's struggle for self-determination, it seems natural to assume that Mau Kuru was murdered in I999 because he supported independence. This is the view of the militiamen who killed him, of neighbors and other people in Maubara who heard about the murder through word of mouth, of resistance leaders in Dili and beyond, and of foreign observers. The murder was a tragedy, it was further evidence of the brutality of the occupying regime, and it was a violation of human rights, but viewed in national terms it seems perfectly comprehensible. And yet members of Mau Kuru's own family remain unsure why their relative was murdered. Juxtaposed against the certainty with which other actors view the murder, the family's confusion demands explanation. The confusion arises, I believe, because the relatives know something that does not fit within any of the dominant explanations-the causal explanation that Mau Kuru was murdered because he supported independence, the rationalization that the struggle for independence entailed risks, or the conclusion that the murder was part of a widespread and systematic pattern of human rights violations. The family knew that history mattered.

Island Southeast Asia has been the site of many studies of how historical knowledge is selected, transmitted, and transformed across time. The earliest scholar-bureaucrats and anthropologists to conduct research on the island of Timor during the first half of the twentieth century recorded legends about the arrival of ancestors from across the sea, the founding of ritual centers and the division of authority, and oral histories tracing local 
lineage "houses" (uma lisan) back to the paramount ritual center on the Benain plain in southwest Timor. ${ }^{1}$ Subsequent scholarship has explored structural features of these narratives, variation across the region, and how origin stories inform meaning in the present. Writing on the ethnic Mambai of East Timor, for example, Elizabeth Traube documented and unraveled origin stories in which the Portuguese colonizers are domesticated as long-lost younger siblings who, returning from a distant shore to Timor, forgot their origins that the Mambai had so carefully protected and transmitted from generation to generation. ${ }^{2}$ More recently, based on extended fieldwork in Laclubar subdistrict in the central highlights, Judith Bovensiepen has explored how Idate speakers inscribe the historical past, the sacred, and experiences of violence in the landscape, and how, after forced dislocation, the return to places of origin presents opportunities to reclaim meanings that place and the past hold. ${ }^{3}$

This chapter begins with an origin story that is often recounted in Maubara. But rather than assume that this represents either actual events in the historical past or an allegory through which the painful experience of colonization is domesticated, the aim is to use this as a starting point from which to consider what can be learned about early modern Maubara from the archival record. The information that emerges may be wholly unknown to the people of Maubara today, and yet it is projected ever so faintly into contemporary notions of identity and claims to precedence, ${ }^{4}$ authority, and recurrent conflict. It is a story of Mau Kuru's ancestors in the early eighteenth century, and is therefore the starting point for unraveling why he was murdered in 1999 and the meaning his murder held for people living on Mount Maubara.

\section{Strangers in Maubara}

According to oral tradition, the first man in Maubara emerged out of the ground following a great flood. He had a hairy tongue and did not cook his food. One day a person arrived from the island of Alor, to the north, and traded fire for a plot of land on the mountain. Since then the first man and his descendants have cooked their food and the hair disappeared from their tongues. The descendants of the first man, it is said, were divided into a number of lineage "houses" (uma) defined by descent, marriage exchange (wife-giving and 
wife-taking houses), and ritual obligations. ${ }^{5}$ The most senior of these houses were Ikolau, Kaisave, and Raelete, located in close proximity to one another in the cool upper reaches of the mountain. In the absence of structured supralineage authority, however, the region was in a state of virtual anarchy: murder and theft were common and mutual suspicion a constant fact of life. This was an indigenous Hobbesian state of nature.

Order arose not from within local society but due to the arrival of strangers. The people of Maubara tell of the arrival of three royal brothers from Suai Loro, the twin polities of Suai and Camenassa located on the south coast that were closely linked to the prominent ritual center of Wehali in what today is Indonesian West Timor. ${ }^{6}$ The three brothers were received by the leaders of Ikolau and Kaisave, who set about preparing white palm wine for the visitors. ${ }^{7}$ When the liquor was ready the three brothers from the south drank without first asking permission. The people of Ikolau and Kaisave were worried and asked, "Are these good men or devils?" The following account was provided by Miguel Sanches:

So the three chiefs said to the people of Ikolau and Kaisave: "We are embarrassed to hear you ask if we are good or are devils. So let us take an oath together." The people asked: "What sort of oath?" The three chiefs told the people to get leaves from the ai hanek tree at a place called Rito Luli E Meta. The leaders of Ikolau and Kaisave each took a leaf, and the three chiefs together took a third leaf. They folded the leaves to make small ladles from which to drink the palm wine. There was one leaf for the people of Ikolau, one for the people of Kaisave and one for the three brothers from Suai Loro. Together they took an oath that after drinking the palm wine the person whose leaf turned into a gold medallion would win, and those whose leaves turned into silver medallions would lose. Then they drank the palm wine. The leaves held by the representatives from Ikolau and Kaisave turned into silver medallions, and the leaf of the three brothers turned into a gold medallion. The representatives of Ikolau and Kaisave said to the chiefs: "Now you three have won. We submit our people to you to lead."

The representatives of Ikolau and Kaisave then divided the territory of Maubara between the brothers. The eldest brother, Manu Muno, was given the 
rank recete and told to make his home in Vatuvou, located on the eastern part of the long mountain ridge, which was particularly well suited to agriculture and raising animals. The middle brother, Manu Tela, was given the rank repreto and made chief of Guguleur, near the summit of Mount Maubara. ${ }^{9}$ The youngest brother, Mau Mori, was asked to reside at Manukati Lauwana, a knoll on the mountain ridge a few kilometers from the peak, and was appointed to be the ritual leader with responsibility for the production of palm liquor and handicrafts at two locations on the coast. These brothers are known in Maubara as the Loro Liurai-the sun lords. ${ }^{10}$

After dividing the territory between the brothers, the representatives from Ikolau and Kaisave selected three "lieutenants" 11 to assist the new rulers: one from a hamlet in present-day Lissadilla, on the south side of the mountain; one from Vatuboro, located at the mouth of the Loes River to the west of the mountain; and one from the settlement of Daire, on the north coast. ${ }^{12}$ Finally, the men from Ikolau and Kaisave asked, "So what duties will you give us?" The new rulers assigned the people of Ikolau and Kaisave responsibility for dispute resolution, called Taki Hae Koir Hae. "If there is a death in Ikolau or Kaisave," the brothers told them, "you have the duty to report to us. If someone is born you must also report." In other versions the people of Ikolau, Kaisave, and Raelete were given a judiciary role that included overseeing the inauguration of the paramount ruler in Guguleur, where the second brother and his descendants lived. ${ }^{13}$

The three brothers had, in the long tradition characteristic of the eastern part of the vast archipelago, become stranger kings, presiding over the scattered settlements on the coast, the mountain proper, and in the great river valley to the south. Such origin narratives, which are common throughout Timor and the wider Austronesian region, connect the autochthonous people with the arrival of outsiders. ${ }^{14}$ In some places the stranger delegates authority over the visible world to the autochthonous population while having himself installed as the authority over the ritual realm, while in other places the stranger exercises political power while ritual authority remains vested in the original people. Accounts in Maubara appear to merge these patterns, with the strangers enjoying both paramount political and ritual functions while the autochthonous population retains a subordinate judicial function. 

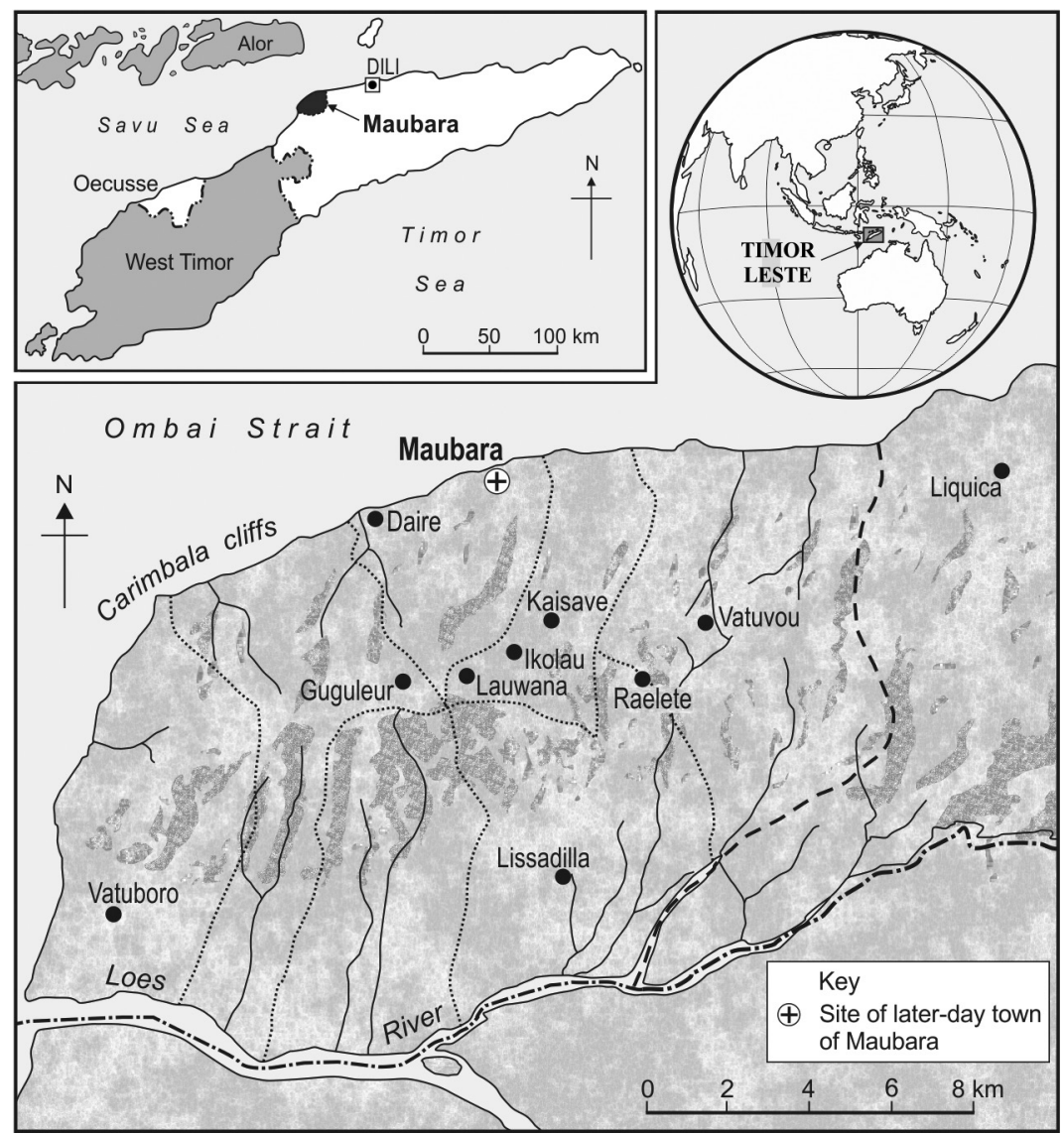

MAP 1 Maubara, showing early named places

It is said that from the time of these first stranger kings Maubara's reach extended well beyond the boundaries of the present subdistrict. Maubara held some sway, if not outright authority, over many of the small inland polities scattered throughout the Loes River watershed. Still other sources claim that Maubara's authority extended along the coast to the west and included the micropolities of Sanir, Cova, and Balibo. Yet another claim is that Maubara's reach extended across the Ombai Strait to the Kolana region at the eastern end of the island of Alor. ${ }^{15}$

Scholarship on the Lesser Sunda Islands, which form a chain from Bali eastward to Timor, has highlighted the importance of genealogies, which are carefully guarded and passed from generation to generation. ${ }^{16}$ 
In Maubara, however, the earliest named figures are shrouded in mystery. After the three strangers from the south, the next ruler of Maubara who is identified by name is one Dom José of Guguleur. A second name that has survived in the oral tradition is an individual called Barnado from the Ikolau-Kaisave area who, it is said, "received" the Europeans and "appointed" the governor of Timor by tapping his hand on a book three times. ${ }^{17}$ Informants do not know when either of these men lived, but the known genealogies suggest that Barnado lived in the late eighteenth century and Dom José during the first half of the nineteenth century. They are relatively recent figures, yet they embody the two sides of the origin story: the one representing the original people of Maubara, the other the stranger kings who came to rule the once powerful kingdom. One cannot help but wonder why the people of Maubara have not retained specific knowledge-names, events, or interactions with foreigners-from the centuries that lie between the founding story and the nineteenth century, when the Portuguese began to construct a colonial regime.

We can begin to explore this question by recalling that even at the furthest reaches of the Lesser Sunda Islands, for centuries Maubara and the other indigenous polities on Timor were enmeshed in long-distance networks of trade. Three of these networks were of particular importance for understanding the history of violence. Chinese ships traded in Timor from at least the thirteenth century, when the first reference to the island appears in texts. One such text comments that "silver, iron, [porcelain] cups, cloth from Western countries [referring to Cambay] and coloured taffetas" could be traded for valuable sandalwood at "the twelve localities that are called ports." ${ }^{18}$ These ports were concentrated on the calmer north coast, and Maubara was most likely among those known to Chinese sailors. In the fifteenth century, however, the Ming dynasty placed an official ban on overseas trade. Chinese involvement in the southern seas (nan yang) continued, but without imperial backing. The locus of this trade was Malacca, the great emporium on the Malay Peninsula where silk and ceramics from China, cloth and jewels from India, and spices and forest products from Southeast Asia were exchanged. Remarkably, the Chinese presence in Maubara prior to the European age of discovery is commemorated (erroneously, as we will see) on a polished black gravestone erected in 1995 in the hamlet of Lissalara, near the peak of the mountain, where the 
second of the brother's from the south was told to reside. The first person listed on the gravestone is "Avo Kura Fatima Lai, born I4I5-died I66o." 19 The name is a fusion of the Tetum word for grandparent (avo) and proper names from three languages: Kura from Tokodede, the language spoken throughout Maubara and Liquica; Fatima originally from Arabic and transmitted to both Portuguese and Malay; and the Chinese surname Lai. Avo Kura Fatima Lai, according to oral tradition, was a local woman who married the son of the first Chinese man to live permanently in Maubara.

Portuguese ships first reached the island of Timor in the early sixteenth century, but for the next hundred years the Portuguese presence was limited to the seasonal trading expeditions from Macau and later that of smaller sloops sent by Portuguese merchants based in Makassar, at the southwestern tip of Sulawesi, to collect sandalwood, honey, beeswax, tortoiseshell, and slaves. Meilink-Roelofsz writes, "The Portuguese managed to obtain a large share in the sandalwood trade of Solor and Timor, yet they did not succeed in monopolizing it entirely since the old-established Chinese trade continued to hold its own there. Apparently only the Chinese could supply these islanders with the goods they particularly liked, goods which could not be delivered by the Portuguese, the Javanese or traders from other places.” ${ }^{20}$ Portuguese activity in the Timor region was limited by the availability of personnel and shipping (it is estimated that in the seventeenth century there were no more than seven to eight thousand Portuguese men in Asia), which in turn fell victim to Iberian politics. In I580 the Portuguese Crown was taken over by the Bourbon dynasty in Spain. Papal decrees ensured that the Portuguese maritime empire remained separate from its Spanish competitor, and so the nascent administration in Goa, which served as the headquarters for the Portuguese in Asia, was largely left to its own devices. A Portuguese map of Southeast Asia from the early seventeenth century shows a number of named places in Timor, including the Botobora River-clearly a conflation of the Loes River and the small polity of Vatuboro, which according to oral tradition was under the larger Kingdom of Maubara. ${ }^{21}$ Portuguese documents from the seventeenth century also note that the Kingdom of Maubara was one of a number of places where Dominican missionaries were active on Timor, though these do not provide specific information about rulers, social structure, conversions, or trade. ${ }^{22}$ 
Portuguese maritime supremacy in Asia was short-lived, however. During the early seventeenth century the Dutch East India Company (Vereeenigde Oost-Indisch Compagnie, VOC) displaced the Portuguese from Ambon and soon set its sights on seizing control over the sandalwood trade from Timor as well. To this end, in I626 the VOC issued a ban on Chinese vessels sailing to Timor. ${ }^{23}$ Over the next three decades the VOC displaced the Portuguese in quick succession from Japan (I638), Malacca (I64I), Ceylon and several ports in India (I658), and finally Makassar (I660). ${ }^{24}$ The Dutch East India Company rapidly expanded its presence in the western half of Timor during the following decades, largely by mobilizing freed slaves, called mardijkers (freemen), from the island of Roti. Vatuboro, located at the mouth of the Loes River, appeared on seventeenth maps and in the company's voluminous business correspondence, but the name "Maubara" emerges in the archival sources only at the start of the eighteenth century. ${ }^{25}$

People in Maubara today are keenly aware that an array of foreigners shaped their past, but they have little notion of when or how this occurred. Some say the Dutch arrived first, others that it was the Portuguese. But there does seem to be general agreement today that foreigners are, at best, peripheral to what really matters: origin stories, lineage houses, and claims to authority. Scholars have attempted to use similar myths and ritual speech in other polities to reconstruct precolonial and early modern histories on Timor and elsewhere in eastern Indonesia, but in the case of Maubara these origin stories and named individuals appear to provide little in the way of concrete information. So it is to the archival record that we must turn.

\section{The Doutels of Guguleur}

The first ruler of Maubara who is identified by name in the archival record appears in the early eighteenth century. This is a man named Dom (Lord) Francisco Xavier, who was from Guguleur, and hence was a descendant of the second of the noble brothers from Suai Loro. His name is found in a list of indigenous rulers who fought on the side of the Portuguese during the great rebellion of the callades in I726, with a note that he contributed twenty-four riflemen and one hundred men with spears to the Portuguese 
military expedition. ${ }^{26}$ But D. Francisco Xavier and the Kingdom of Maubara may not have been quite as willing an ally of the Portuguese as the I726 list suggests. Letters from the time reveal that some of the settlements under the Kingdom of Maubara sided with the rebels. ${ }^{27}$ The Portuguese column, under the command of an officer named Magalhaes de Meneses, marched from Dili-then a minor settlement adjacent to the polity of Motael, and not yet the colonial capital-westward along the coast to the present-day location of the town of Maubara, ${ }^{28}$ and from there over the mountain to the Loes River valley, which provided the most convenient route to the rebels' stronghold in Cailaco. ${ }^{29}$ With a force of several thousand troops entering his territory, D. Francisco Xavier may have agreed to provide men to participate in the military campaign so as to avoid seeing his realm laid waste rather than out of any loyalty he felt for the Portuguese.

Elders in Maubara today have never heard of a local ruler named D. Francisco Xavier, and the 1726 rebellion and Portuguese military operation is not part of the oral tradition (though a few people in Maubara have learned about the rebellion in school or read about it in books). In the search for connections between the archival record and oral traditions in Maubara, D. Francisco Xavier seems to be a dead end. He is, in fact, just the beginning.

In I698, a young aristocrat named Francisco Xavier Doutel from Bragança, in the northeast corner of the Kingdom of Portugal, arrived, via Golden Goa, in the City in the Name of God, as Macau was then known. He married Francisca Pereira, daughter of one of the leading Portuguese families in the city, became a prominent merchant in his own right, was elected to the Leal Senado (Loyal Senate), and in I7Io was appointed ouvidor (auditor). ${ }^{30}$ During this period Portuguese ships arriving in Timor were finding it increasingly difficult to fill their cargoes with the valuable sandalwood for which the island was famed because the more numerous Chinese sloops were delivering much of the wood cut by the indigenous population directly to Batavia. ${ }^{31}$ In I7I2, Doutel and a fellow merchant and senator named Luis Sanches de Caceres won the right to send the annual trading mission from Macau to the Solor and Timor islands. ${ }^{32}$ Their fleet consisted of three ships. Doutel's ship, the São Francisco Xavier, traded in Maubara; Caceres's ship, the Nossa Senhora do Rosario, traded fifty miles to the east at the twin polities of Laclo and Laicore; and a third ship, the 
São Pedro, traded in Vatuboro, at the mouth of the Loes River, and then toward the eastern end of the island. ${ }^{33}$ Remarkably, and by mechanisms that are not entirely clear from the sources, the names of the owners and their ships passed to the indigenous rulers with whom they traded. The ruler of Maubara hence became known by the Portuguese name D. Francisco Xavier and, as the next chapter will show, his son and several subsequent generations carried the surname Doutel. The ruler of Laclo became known as D. Paulo Caceres, after the owner of the ship that traded with his kingdom, while the ruler of neighboring Laicore earned the surname do Rosario, after the ship itself. Finally, the ruler of Vatuboro became known as D. Pedro. ${ }^{34}$ So we know with certainty that the name Francisco Xavier was given to (or taken by) the ruler of Maubara in or very soon after I7I2, though it only appears in the available records fourteen years later at the time of the Cailaco campaign.

Two years after the I726 Portuguese military campaign Maubara again appears in the archival record, but this time in that of the Dutch East India Company. An entry in the General Missives of the VOC dated 8 December I728 tells of a ship sailing from Banda, where a century earlier the Dutch had committed genocide to facilitate their monopolistic control over the cultivation of nutmeg and mace, to the VOC factory in Kupang, at the western end of the island of Timor. This entry notes that "the ship Leti was carried by the current and wind to Timor, where three sailors deserted, although not to the captain of Maubara, Lorenzo da Costa, nor to the Governor of Dili, Joachim de Matus [sic], and in that place the Leti was repaired and then allowed to depart." ${ }^{35}$ The reports provided by the ship's crew to their superiors in Kupang may have stimulated Dutch interest in drawing Maubara into the VOC orbit. Attesting to Maubara's importance as a center of trade, the same VOC record notes that shortly after the visit of the Leti a Makassarese ship (or, possibly, multiple ships) carrying more than eighty sailors arrived in Maubara, where it stayed for over a month to engage in trade. ${ }^{36}$

Portuguese success against the rebellious callades of the interior in I726 was short-lived, and in I73I a new alliance of rebels from the southcentral region of the island besieged the Portuguese military force in the coastal settlement of Manatuto. ${ }^{37}$ After his troops had made a narrow escape and retreated to Lifau, Governor de Mello sought to normalize 
relations with the indigenous polities that the Portuguese Crown claimed as vassals. In one account this involved a formal peace treaty and a new assessment of the annual tribute (finta) that each of the indigenous kingdoms was required to pay to the white overlords. Remarkably, based on a visit to Maubara in the early twentieth century, the Dutch scholar G. P. Rouffaer reported that the royal family of Maubara still possessed a letter from the Portuguese governor dated 20 October I732. ${ }^{38}$ Although Rouffaer did not record the contents of the letter, VOC sources reveal this was official acknowledgment that the ruler of Maubara had paid I,I47 pardaus in return for the kingdom's release from Portuguese claims. ${ }^{39}$ Seeing an opportunity to shift allegiances, the ruling family of Maubara promptly forwarded a copy of the letter to the VOC agent in Kupang, Hans Albrecht von Plüskow, for inspection. That the ruler of Maubara did in fact successfully switch allegiances at this time can be confirmed from a Portuguese document dated I733 stating that the Kingdom of Maubara was then under VOC suzerainty. ${ }^{40}$

There was one additional twist in the transfer of the surname Doutel to the ruling family of Maubara. In Macau, the Portuguese fidalgo Francisco Xavier Doutel had enjoyed a long and illustrious career in public life and the equally profitable pursuit of private trade as far as Canton and Japan, Manila and Cavite, Solor and Timor, and Surat and other ports in India. ${ }^{41}$ After the death of his wife, Doutel devoted much effort and considerable wealth to sponsoring the construction of churches in Macau in her honor. Then, in late I745, the Portuguese Viceroy in Goa appointed Francisco Xavier Doutel to serve as governor and captain general of the Islands of Solor and Timor. Before setting sail to take up his new post, Doutel penned a letter to King João V ("the Magnificent”) of Portugal, expressing the honor he felt and his unwavering loyalty to the monarchy. There is no evidence that once in Timor Governor Francisco Xavier Doutel ever visited or corresponded with the family in Maubara that bore his name, but given the proximity of Maubara to Lifau and Portuguese concerns about Dutch intentions, he was probably aware of the ruler's name. ${ }^{42}$ Whatever opportunity the governor may have had to interact with his disloyal namesakes down the coast was soon cut short: less than a year after taking office Governor Doutel died. ${ }^{43}$

At first glance there appears to be little congruence between the oral tradition about the arrival of stranger kings who founded the Kingdom of 


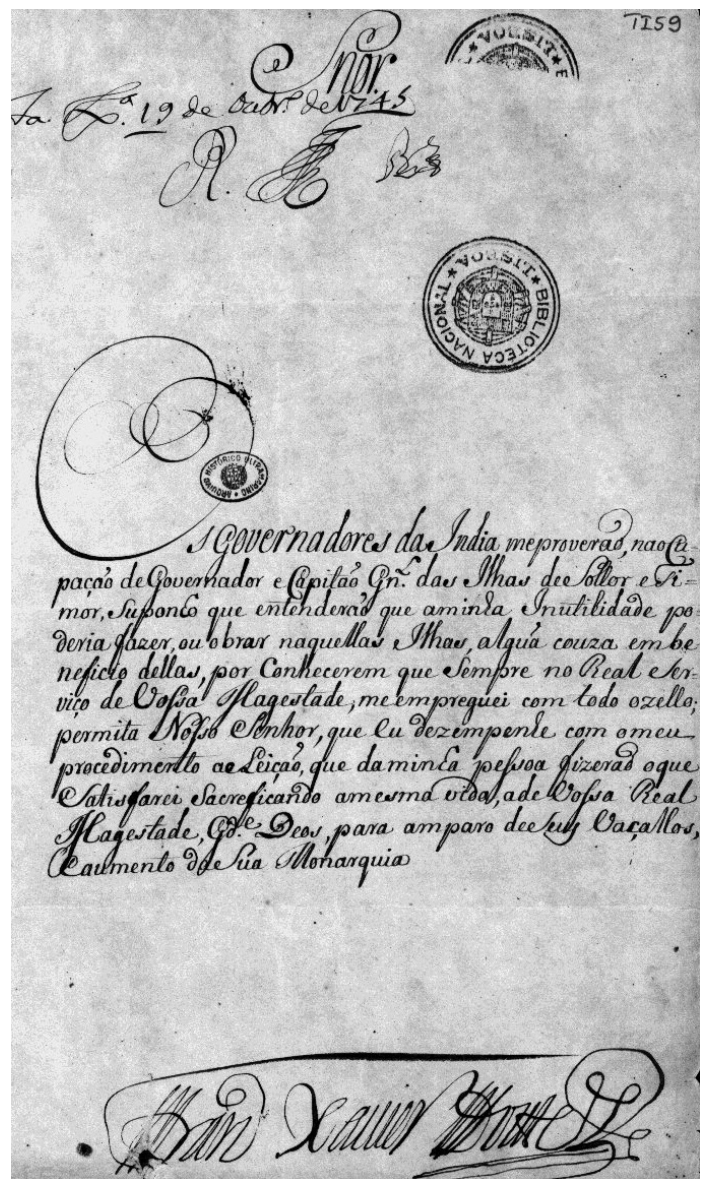

FIGURE 1 Letter from Francisco Xavier Doutel to King João of Portugal, I745

Maubara and the scant information gleaned from the colonial archives about the first recorded ruler and his relations with the Portuguese and the VOC. And yet, these sources do suggest three sets of overlapping cleavages: a division between the indigenous population and the stranger kings who were granted formal authority, territorial and functional differentiation among the stranger king brothers and their descendants, and the supralocal rivalry between the Portuguese and the Dutch maritime empires. As subsequent chapters demonstrate, the interplay of these cleavages informed recurrent violence in Maubara over the next three centuries. 


\section{Life on the Mountain}

Before proceeding with story of the Doutels and the subsequent history of violence in Maubara, it is first necessary to provide a brief description of the environment and social organization in Maubara in the early eighteenth century. Archival sources are silent on these topics, but there are a number of features about which it is possible to comment with a fair degree of certainty.

Maubara is located on the calm north coast of the island of Timor, bounded on the north and west by the Strait of Ombai, on the south by the wide Loes River valley, and to the west by what was then the Kingdom of Liquica. Between sea and valley, the compact 270-square-kilometer area is dominated by a steep-sided mountain that rises from the coast to a long east-west ridge with an elevation of about nine hundred meters and culminates at the twelve-hundred-meter-high peak of Mount Maubara. The bend in the coastline and massive river valley made Maubara a strategic point in interregional communication and trade, while the mountain provided excellent natural defenses.

As is the case across the entire northern littoral of Timor, the rainy season typically begins in mid-November and lasts until March, though this can be quite irregular. Torrential runoff fills streams and broad riverbeds before emptying the silvery, silt-laden waters north into the sea. During the dry season the lower elevations are parched and brown and the riverbeds form a highway of boulders, gravel, and sand. In the eighteenth century the middle and higher elevations of the range were still covered in primary forest or secondary growth on fields left fallow. The Loes Valley, though crisscrossed with footpaths, was still a wild place of high grasses and scrub, eucalyptus, and other drought-resistant trees. Wildlife was abundant in the eighteenth century, with deer, boar, monkeys, squirrels, constrictors and venomous snakes, and an array of dazzling tropical birds.

There are no firsthand accounts of human settlement patterns in the eighteenth century or earlier, but hamlets were most certainly small and dispersed. In the late nineteenth century, for which data are available, hamlets in the Kingdom of Motael, located to the west of Maubara near present-day Dili, had an average of seventeen hearths and a population of one hundred people. ${ }^{44} \mathrm{~A}$ century earlier, hamlets in Maubara 
were certainly no larger than this, and may in fact have been somewhat smaller. Quite a few hamlets probably had fewer than fifty inhabitants, consisting of no more than a single extended family or lineage. The total population of Maubara at the time of D. Francisco Xavier may have been as low as three thousand and perhaps as high as five thousand, but there is no way to know with any certainty ${ }^{45}$ Most hamlets were located near a spring or regular supply of water, and hence were in the heavily forested upper reaches of the mountain, though there were a smaller number of lowland hamlets as well. In the story of the three brothers from Suai Loro, the "lieutenants" appointed to serve the new stranger kings were selected from two coastal settlements-Daire and Vatuboro-that must have served as the beachfronts for trade with foreign ships and one hamlet in the Loes Valley-Lissadilla-that was probably a key node in trade going up and down the watershed. There does not appear to be any evidence that settlements in Maubara were fortified, for at higher elevations there was no need and at lower elevations fortifications would not have done any good against outsiders (whether Portuguese, the creole Topasses ${ }^{46}$ Dutch, or Makassarese) with superior technology.

Dwellings were simple, the basic structure consisting of wooden posts and cross beams, walls of flattened bamboo or the ribs of palm fronds tied or plaited together, and the roof of thatch. ${ }^{47}$ Floors were hard-packed dirt. Most homes probably had a separate cooking area with a covered fireplace. Adults and children spent a great deal of time around the fire, either cooking or simply keeping warm, and in doing so inhaled large quantities of smoke. Hamlets or individual families, depending on their size, also had separate structures built on tall wooden posts for storing food, though damp, mold, and rats were constant problems.

Prior to the arrival of the Portuguese and Dutch, the staple crops on Timor were a variety of tubers (keladi, konbili, etc.) and limited amounts of rice grown in the Loes Valley. In the sixteenth and seventeenth centuries Europeans introduced a number of New World crops, of which corn and cassava were the most important. Corn could be grown on even the steepest hillsides, though it was heavily dependent on the timing of the rains. Cassava, by contrast, grew easily and had the added benefit that it could be left in the ground for up to two years and still be edible. By the eighteenth century, when the Doutels were engaged with the competing European 
maritime powers, corn and cassava had spread widely and probably made up the bulk of calories in the diet. ${ }^{48}$ Fields were rotated and crops interspersed. The people of Maubara kept ponies for transportation, pigs, goats, and chickens for food, and dogs for hunting and security (though these were eaten as well). People in the Loes River valley may have had small numbers of water buffalo, but there were probably few on the upper reaches of the mountain. By the early nineteenth century, as will be seen, there were also sheep and ducks. Game was plentiful and deer and wild pigs were eaten regularly; monkeys and squirrels, found in the forest at higher elevations, were also eaten. There is a long history of alcohol production-both fermented toddy and distilled liquor-and palm-based drinks were probably produced and consumed in considerable quantity.

Timorese produced double-woven cloth (T. tais; I. ikat) worn as sarongs or, in cold weather, as wraps. People in Maubara produced some ikat, but much of the cloth probably came as trade goods from elsewhere in Timor and from Java, with more valuable items of Indian origin. By the eighteenth century, as Maubara's alliance and trade with the VOC intensified, women had adopted the Malay-style blouse (kebaya), and men took to wearing pants and even jackets. ${ }^{49}$ Men wore leather belts on which to hang knives and even pistols. Headscarves were worn on ceremonial occasions and during warfare.

Social structure in Maubara was based on lineage "houses," involving exchange between wife-giving and wife-taking houses, and a tripartite division of nobles, commoners, and slaves, at least in theory. There is no information about family structure in the early modern period, and it would be a mistake to extrapolate back from the present, or even from late nineteenth-century accounts. It is certain, however, that polygamy was practiced, at the very least by the ruling families. Adoption was probably common as well, involving both children passed between related families as well as those given to pay a debt or secure an alliance. ${ }^{50}$ Birth and mortality rates were almost certainly very high, as is the case today. Tuberculosis, cholera, and malaria were all endemic, and there is evidence that venereal disease was common. We do not know anything about sexual practices, and one must be careful with the later colonial sources for which it can be difficult to distinguish accurate reporting from perverse colonial fantasies about indigenous life..$^{51}$ 
The social position of the Doutels was announced in the names of their house, No Liku No Besi, which might be rendered roughly as "King of All, Brave King," and their settlement, Lissalara, meaning "inner palace.” In reality, the conditions of ruler and ruled differed very little. The Doutels and the related ruling family of Vatuvou lived at higher elevations not simply because this is where they had been assigned to live when the brothers from Suai-Camenassa first arrived, but for three strategic reasons as well: health (including fresh water from mountain springs and crop production), security from invaders, and because the mountain ridge afforded views out to sea and into the Loes Valley that allowed them to survey the trade routes.

Leadership involved not only the paramount ruler (dato in Tokodede, liurai in Tetum, and from the mid-nineteenth century on rei and régulo, from Portuguese) but also ritual speakers (T. lia nain) and the guardians of sacred objects (T. lulik). Anthropological scholarship on Timor has often highlighted dualism in indigenous thought, including the distinction between the "political" and "ritual" spheres. When the brothers from Suai Loro arrived, the second was granted paramount "political" authority and the youngest was appointed as the "ritual" leader. ${ }^{52}$ Each house, representing a lineage, also had its own ritual specialist. Powerful objects were stored in a sacred house (uma lulik), but ceremonies might be conducted at a variety of locations-where an animal was sacrificed, where an important event had occurred, or to mark a boundary-and these sites were likely to be maintained or remembered over time. ${ }^{53}$

Traditional systems of dispute resolution and justice, about which much has been written for East Timor as a whole since 1999, are far from clear. ${ }^{54}$ In the account of the Loro Liurai, it is often said that the original inhabitants of Ikolau, Kaisave, and Raelete were granted a "judicial” function. ${ }^{55}$ But those who make such claims provide highly contradictory accounts. According to one elder in Maubara who is generally recognized as an expert on both local history and cultural matters, prior to Portuguese colonial rule the punishment for almost any offense was death, and it was only with the introduction of Catholicism in the early twentieth century that the killing of the faulty party was replaced with the sacrifice of an animal. ${ }^{56}$ Given the complete lack of evidence for the early modern period, one is forced to conclude that there was no "legal system" as such. The 
heads of the various hamlets, often together with the ritual specialists, dealt with grievances and disputes. Precedence may have played a role at times, but more often decisions reflected the personal interest of the most influential figures in the hamlet or, above the hamlet, the ruler of the kingdom. Much depended on the social status and proximity to power of both the "perpetrator" and the "victim."

The various stories about the brothers from Suai-Camenassa suggest that prior to their arrival violence had been endemic in the hamlets around the mountain, as was certainly the case elsewhere in Timor. The institution of rulers in Vatuvou and Guguleur may have brought the promise of supralocal sanctions and retributive justice, but Maubara remained a violent place. Furthermore, as a major node in interregional trade, the rulers in Maubara relied on armed parties to secure coastal trade with foreign ships and to safeguard the inland trade up the Loes Valley. Putative expeditions against inland polities were probably common.

Aside from subsistence and the observation of rituals, what mattered most to the Doutels and the lesser nobility of Maubara was trade. This involved both trade in local products-food items, honey, sandalwood, weapons, slaves, and so on-up and down the watershed and the coastal trade with outsiders for imported goods-Chinese ceramics, Javanese and Indian textiles, glass beads, firearms, axes, and other metal goods. Drawing on Antonio Pigafetta's description from Magellan's voyage around the world and the writings of subsequent early European travelers to Timor, Meilink-Roelofsz writes, "The chiefs had some sort of supervisory function, for when foreign merchants arrived the chief and his entire retinue went to the market place, where the inhabitants had gathered to barter their [sandal]wood with the foreigners. Duties had to be paid, but not very heavy ones. No trading took place in the chief's absence 'for fear of disturbances.' It is not clear whether this meant the chief had some sort of priority right of sale. Besides sandalwood, Timor exported large quantities of wax and honey, and the slave trade flourished there too." ${ }^{57}$ The island of Alor, twenty kilometers across the Ombai Strait, was the major source of slaves. Oral tradition holds that the people of Maubara would make a large fire on the beach with coconut husks, which produce a large volume of smoke, as a signal for people on Alor to come across the strait in small boats with slaves and whatever other goods they had to trade. ${ }^{58}$ The 
coastal and watershed trade, of course, might take place in different locations, but were fundamentally part of a single system connecting Maubara and other points on Timor to Makassar and Java, Malacca, Macau and Goa, the vast markets of China and India, and eventually the great European emporiums of Lisbon and Amsterdam.

Insofar as opportunities for trade were greatly expanded by the arrival of foreign ships, D. Francisco Xavier and other coastal rulers would not have been entirely hostile to newcomers. The coming of Europeans expanded the available range of trade products and made firearms readily available. Competition between foreign traders may even have improved the bargaining position of someone like D. Francisco Xavier, but there was the constant danger that allegiance to a single foreign power and the burdens of tribute would become restrictive. Without indigenous sources or detailed foreign accounts of engagement with rulers, however, it is impossible to comment on how people in early eighteenth-century Timor viewed indigenous political authority, the arrival of foreigners, or the meaning of European conceptions of tribute, vassalage, and sovereignty.

\section{Conclusion}

The account of the three brothers from Suai Loro who become stranger kings is by no means unique to Maubara. Similar stories that trace the origins of ruling houses to the polity of Wehali are found in many places in East Timor, and their ubiquity suggests that Wehali exerted an attraction on the peoples in the eastern half of the island. But it should not be assumed that the stories tracing origins to sojourners from the west are necessarily true; rather, they may have become a useful embellishment in the making of purely local claims. Meanwhile, the account of the earliest identifiable ruler of Maubara and the kingdom's position in long-distance networks of exchange are based entirely on Portuguese and Dutch archival materials and are organized around foreign voyages, trade, and the struggle to exert external authority. These do not, and indeed cannot, account for local conceptions of power or understandings of Maubara's relations with other polities or with the foreign other.

Interviews and casual conversations in Maubara over nearly a decade have not revealed any indication that the local population today is aware 
of how their ancestors negotiated the earlier rivalry between the Portuguese and Dutch. Quite the contrary, in discussing their history people in Maubara often expressed confusion over when the Chinese, Portuguese, and Dutch first arrived in Maubara. No one I have spoken to had ever heard the name D. Francisco Xavier, and his living descendants were completely unaware that their ancestors were once known by the surname Doutel, let alone that the name came to them, via Goa and Macau, from an aristocratic family in Portugal. Although the people of Maubara have not transmitted and retained oral traditions about the early eighteenth century, there is an underlying congruence between the story of the three brothers from Suai Loro and the archival record. For the origin story is not simply one of a foundational act. Within this story is imbedded functional division between the executive authority of the stranger kings and the autochthonous population as well as a territorial division between Guguleur and Vatuvou. Out of this emerges the potential for rivalry among the descendants of the Loro Liurai and between them and the population at large. These divisions were to reverberate across the centuries and resurface in 1999. 


\title{
Maubara and the Dutch East India Company
}

\begin{abstract}
$U$ ntil quite recently there has been a consensus among scholars of Timor that the indigenous population was generally hostile to European encroachment and opposed colonial rule. Portuguese historians have highlighted the heroic efforts of successive governors to quell the nearly perpetual state of rebellion between $\mathrm{I702}$, when the first white governor to reside on Timor was appointed, and 1769, when Governor Teles de Meneses hastily moved the base of Portuguese operations from Lifau to Dili, and again from the I840s until the last great uprising in I9IO-I9I2. Writing against these imperial histories, a handful of non-Portuguese scholars have argued that the many rebellions against white rule were not simply the reactions of peoples who were culturally prone to violence or inherently hostile to foreigners but instead represent the nascent origins of supralocal subjectivities that eventually coalesced into a recognizable modern nationalism in the second half of the twentieth century. Despite the differences in interpretation, both schools have adopted macrohistorical perspectives-the one centered on Portuguese ambitions and imperial grandeur, the other on the nation-to-be.

Adopting a microhistorical approach, by contrast, this chapter reconstructs the alliance between the ruling family of Maubara and the Dutch East India Company (VOC) from the I750s until the I85os. Working between the archival sources and oral histories, the first section examines the intimate relations between the Doutels and the VOC representatives in Kupang, revealing that while the alliance enabled the rulers of Maubara to overcome local factionalism and consolidate their power, it also made the kingdom the
\end{abstract}


target of repeated attacks by the Portuguese and eventually drew Maubara and allied polities into war. With the waning of Dutch and Portuguese influence on Timor during the late eighteenth and early nineteenth centuries, however, local dynastic rulers not only lost opportunities for trade but were also deprived of the foreign backing that had been central to their success. This ushered in a period of renewed local factionalism, conflict, and further violence. The final section of the chapter provides an account of the territorial transfer that was initiated in I85I, agreed to in I859, and finalized in I86I. This transfer marked a sharp reversal in the fortunes of the leading families of Maubara. A period of one hundred years that began with intimate ties between the ruling Doutels of Guguleur and the VOC ended with defeat at the hands of their rivals in Vatuvou and the reimposition of Portuguese authority over the kingdom. Throughout this period violence was a constant fact of life.

\section{"Our Guardian and Protector"}

Despite Portugal's grandiose claims to sovereignty over the Solor and Timor islands, the appointment of successive governors, and formal treaties signed with the indigenous polities, the Portuguese foothold on Timor during the mid-eighteenth century was extremely precarious. Direct shipping between Macau and the capital of Lifau was limited to one or two vessels per year, and there was a severe shortage of European manpower on Timor. "In I75O," Charles Boxer writes, "there were only seven or eight white Portuguese in the island, apart from a few Dominican friars 'whose fruit was not so much that which they gathered in the vineyard of the Lord, as that which they begat in the freedom and licentiousness in which they lived,' as the viceroy of Goa complained.” The weakness of the Portuguese governors presented an opportunity for the enterprising VOC to expand its influence into the central part of the island. The Kingdom of Maubara, which had sought Dutch protection in I732, became the centerpiece of these efforts.

In 1755 the VOC governor general in Batavia appointed the diplomat Johannes Andreas Paravicini to conclude diplomatic agreements with rulers in the Solor and Timor area, to address irregularities in the company's administration, and to improve defenses. As part of this initiative, the VOC resident in Kupang, Elias Jacob Beynon, sent an indigenous ensign named Jacob Pietersz to Maubara to assess the ruler's political allegiance. This suggests that 
whatever agreement Maubara had reached with the VOC in I732 for protection had long since lapsed, and the Portuguese governors in Lifau had continued to demand that Maubara provide beeswax and other goods as part of the annual tribute. Pietersz reported back to his superiors in Kupang that José Xavier Doutel, who had succeeded his father D. Francisco Xavier as ruler of Maubara, "wished to escape from the tyrannical treatment by the Portuguese.” José Xavier Doutel sent his son, Domingos Samuel Doutel, in the care of Pietersz to Kupang to meet with Beynon and make a formal request for protection from the VOC. Replicating the Portuguese system of honorifics and ranks, the VOC granted José Xavier Doutel the title "Dom" (Lord) and his son received the rank of "tenente-colonel" (lieutenant colonel). ${ }^{3}$ Figure 2 shows the rulers of Maubara in the eighteenth and early nineteenth centuries, and a full reconstruction of the Doutel lineage can be found in appendix A.

VOC efforts to entice other local rulers on Timor and neighboring islands to declare their loyalty to the VOC also bore fruit. In June I756 Paravicini hosted a huge gathering of nobles in Kupang at which a contract was signed with (or in the name of) seventy-seven different polities, including a number from the central region of Timor then claimed by the Portuguese Crown. ${ }^{4}$ Among these were Maubara and the two subpolities that provided "lieutenants" in the story of the Loro Liurai-“Botoboroo" (Vatuboro), located at the mouth of the Loes River, and "Nusadila" (Lissadilla), located in the valley to the south of the mountain. ${ }^{5}$

Two years after the Paravicini contract was signed, two ships from Sikka, a polity on the island of Flores, operating at the time out of the Portuguese settlement of Lifau at the behest of the Portuguese governor, attacked Maubara. In response, the VOC resident in Kupang promptly dispatched a ship to provide D. José Xavier Doutel with gunpowder, and soon after a second ship was sent with additional munitions. The available archival sources note that seven attackers were killed and four were taken prisoner, but do not provide information about Maubara's losses. In the wake of the skirmish, D. José Xavier Doutel sent his brother, D. Paulo, and eighteen followers on the ship returning to Kupang, where they reported to the VOC representative that the attackers had attempted "to take the main regent [D. José] and his family prisoner, or else kill them.” ${ }^{6}$

The VOC administration in Kupang, now headed by the Germanborn Hans Albrecht von Plüskow, responded to the news of Portuguese 


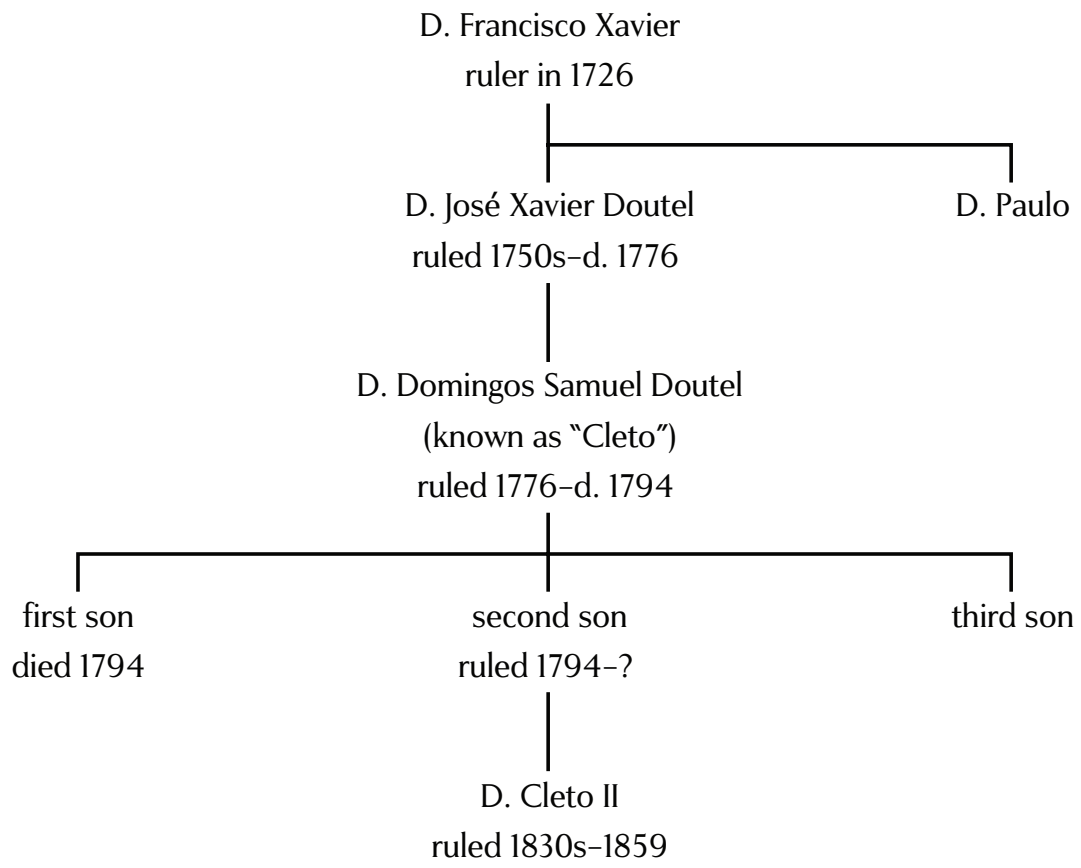

FIGURE 2 Rulers of Maubara, eighteenth and early nineteenth centuries

aggression by sending Jacob Pietersz on another mission to Maubara with a force of one hundred European and Balinese soldiers, who had arrived on Timor as part of Paravicini's initial military force. Pietersz instructions were to identify a location where a fort could be constructed to defend the new VOC allies and interests in the region. The fort, which was constructed at a site on the north coast called Dasilutu, measured eighty feet in diameter and had walls six feet thick. ${ }^{7}$ Even with the new fortification and troops, the threat of attack by the Portuguese and their allies remained. When Jacob Pietersz returned to Maubara the following year with a fresh contingent of soldiers, he again had to assist in defending the kingdom against unnamed attackers. This time D. José sent his son, Domingos, on the return voyage with Pietersz to meet with the VOC officials in Kupang. During this visit Domingos signed a letter renewing the original contract of I756:

I, the signee, declare herewith by word of truthful truth for myself and in the name of the Regent of Maubara, Dom Joseph [José], together with all the rulers and tommongongs [nobles] belonging 


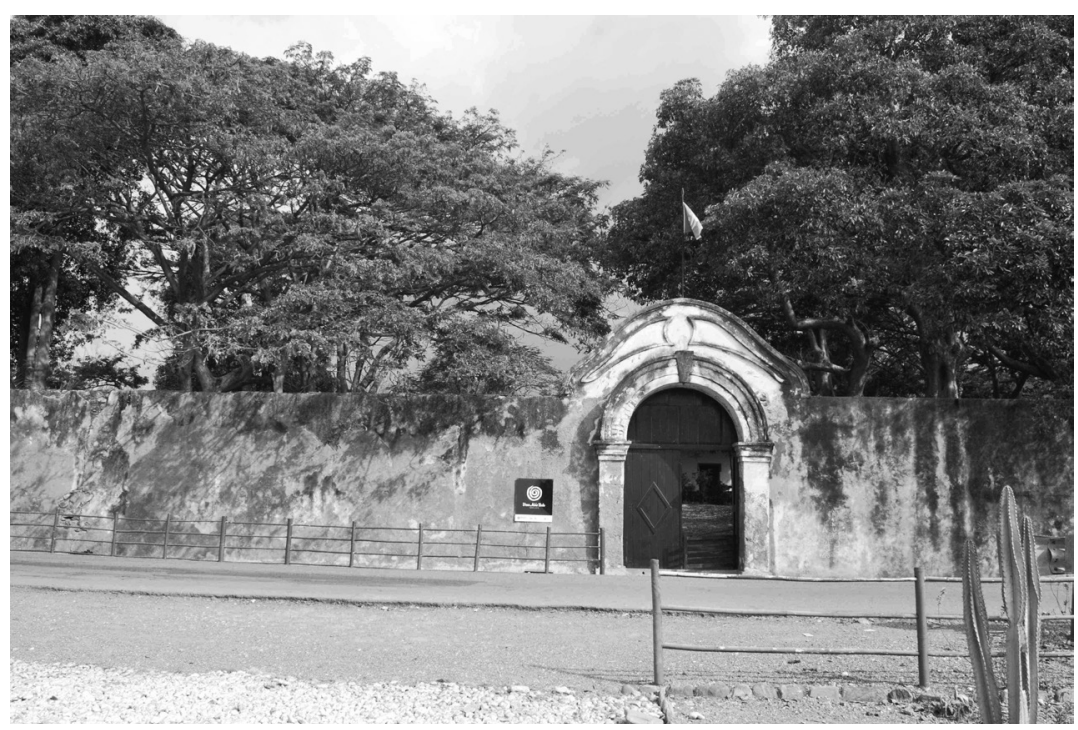

FIGURE 3 Dutch fort in Maubara (courtesy of Selma Hayati, 20I2)

to Maubara, who have sent me to accede and agree with the contract that was established and concluded with the Company and its allies on 9 June I756;

That we the district heads, rulers and tommongongs of Maubara have come over to the Honorable Company of our own free will and affections, and that we have chosen and requested the Honorable Company to become our guardian and protector, and herewith ask again, as we also promise and swear to faithfully uphold and maintain the mentioned contract in all points and clauses, as we have stipulated and undersigned from the very start, and we will not forego the loyalty and sincerity we are obliged to pay to the Honorable Company, which we again promise to faithfully maintain and fulfill.

So help me Almighty God.

[Beneath was a cross, compiled by Domingos Samuel Doutel, lieutenant colonel of Maubara. J. van Este (for the VOC). $]^{8}$

Renewal of the contract served its purpose, for with it Maubara's relations with the VOC became increasingly intimate. But the presence of a permanent VOC outpost and military presence in Maubara enraged Portuguese officials in Lifau, who become even more intent on defeating Maubara and 
asserting sole claim to the eastern half of the island. In I76o, Portuguese officers raised a new military force in Dili, Liquica, and other kingdoms in the east and once again launched an assault against Maubara. In response, a VOC ship carrying forty mardijker soldiers was sent to aid Maubara and reportedly chased the enemy all the way back to Dili. The threat averted, D. José Xavier Doutel and his retinue boarded the VOC ship for the return trip to Kupang to request greater protection from the Dutch against Portuguese incursions. His account of the attack on his kingdom prompted resident Von Plüskow to send a written complaint to his Portuguese counterparts in Lifau. ${ }^{9}$ By this time Portuguese leadership in Lifau was in the hands of a triumvirate, but this arrangement quickly broke down and a struggle ensued pitting Portuguese officials against the Topasse leaders based in the nearby polities of Oecusse, Ambeno, and inland Noimuti. Sensing an opportunity to finally gain the upper hand on his Portuguese rivals, von Plüskow traveled by ship to Lifau, but in the course of trying to install his favored candidate as governor and thereby ensure his influence, he and his men were massacred by the Topasse leaders.

These events in Lifau were to have important ramifications for the Doutels in Maubara. The year after the von Plüskow debacle in Lifau, the newly appointed Dutch resident in Kupang decided to recall the Balinese soldiers from Maubara, most likely to shore up defenses in the western part of the island, and retained only a minimal presence of twelve Europeans at the VOC fort.10 Dom José Xavier Doutel made yet another trip to Kupang in I764, this time bringing a significant quantity of beeswax and sandalwood as a gift to the company. ${ }^{11}$ Later the same year, with the help of a company scribe, Dom José dictated a letter that was sent to the VOC headquarters in Batavia recounting his trip to Kupang and the letters and gifts he had received from the Dutch resident. He also reported that a Chinese merchant from the Portuguese settlement of Lifau named Key Louis had told him that the Dutch intended to arrest him and send him to Batavia. Not believing Key Louis, Dom José was writing to request that the VOC take action against this individual and prevent such intrigues. Finally, he entered a request for the VOC to send someone to teach the children of Maubara the Christian religion. ${ }^{12}$

The Dutch archival sources reveal that during the ten years from I755 until I764 Maubara had become the centerpiece of VOC expansion into north-central Timor. The close relations between the Doutels and the Dutch residents in Kupang made Maubara a target of repeated Portuguese 
aggression, which in turn forced the VOC to deepen its commitment to the Doutels. Beginning in the mid-I76os, however, the influence of both the VOC and the Portuguese on Timor waned considerably, which was to have critical implications for the rulers of Maubara. The Portuguese administration came under increasing pressure from the Topasses and in 1769 , facing an extended siege of his settlement, Portuguese Governor Antonio José Teles de Meneses made the fateful decision to abandon Lifau and move the base of Portuguese operations to Dili, where the ruler of the Kingdom of Motael welcomed him. ${ }^{13}$ Immediately after the move, Teles de Meneses set about renewing tributary relations with the kingdoms throughout the eastern half of the island. The list of tributary vassals drawn up by the Portuguese included Maubara, which was assessed an annual tributary payment of thirty men. ${ }^{14} \mathrm{Had}$ the rulers of Maubara suddenly and without explanation changed their allegiance? The available evidence is mixed, so is worth examining in some detail.

For the ruling family in Guguleur matters were further complicated by Dom José Xavier Doutel's death in I776. His son, Domingos Samuel Doutel (known as Cleto), claimed the throne and may even have been recognized as the legitimate successor by the VOC. An uncle named Dom Paulo disputed the succession, however, and then retreated into the neighboring Kingdom of Liquica, which was a loyal ally of the Portuguese, from where he waged raids against Dom Cleto and his kingdom. The attacks were sufficiently serious that the following year Dom Cleto was forced to abandon the fort on the coast and retreat into the mountains, most likely back to the family home near the peak of Mount Maubara. This may not have been a simple struggle for power, but rather a clash over strategy: the younger Dom Cleto may have insisted on maintaining the family allegiance to the VOC, with which he was on very close terms, while the older Dom Paulo either succumbed to pressure to acknowledge Portuguese suzerainty or sided with the family's distant cousins in Vatuvou, located immediately adjacent to Liquica. Further evidence of the internal struggle appears three years later in a VOC report:

Maubara was accepted as ally in the year 1759 [sic, 1756]. Its people were now [in 1779] withdrawing from the Maetschappy [VOC], and instead delivered the products of the land to the Portuguese. The VOC, namely, had not been able to reach its aims, to facilitate trade in Belo [the eastern half of the island] by means of its Maubara ally. 
The writer [the resident in Kupang] thought that it would not be too costly for the Company to bring the Maubara peoples under their duty again. Maubara, on the other hand, was far away from the VOC outpost [in Kupang] and close to Portuguese territory, which led to Maubara having contacts with the Portuguese..$^{15}$

Despite the resigned tone, the report goes on to explain that in July I779 the "King of Maubara" had sent a letter with a Chinese ship sailing to Kupang to request a European interpreter as well as soldiers and ammunition to defend Maubara from the Portuguese and their allies. The VOC report continued, "Dom Cleto now applied for help and said that he would rather die than leave the Maetschappy [VOC].” And indeed, in I788 a Dutch missive commented that a "stone fort" (perhaps upgrading the original fortification) had been constructed in Maubara and that Dom Cleto "remained faithful to the VOC." ${ }^{16}$ A few years later VOC documents report that Maubara "came under severe threat from Oecusse and Ambeno, and this time [resident] Wanjon ... gave his blessings to Alphonsus Adranus to intervene in Maubara, on the condition that it must not be known that Kupang was behind the enterprise." 17 The solution was for the VOC to encourage the emperor of Greater Senobay, a large polity in the western half of the island that was at least nominally affiliated with the VOC, to support Maubara in its struggle against the Portuguese. Again, however, death intervened: in I794 Dom Cleto and his oldest son died, quite likely in the course of defending their kingdom against Portuguese attacks..$^{18}$ Dom Cleto's second son immediately sent a message to Kupang requesting that "someone from Kupang should come over to Maubara as soon as possible, in order to present him [the second son] as king before the people. ${ }^{19}$ Indeed this request was heeded and the installation was fulfilled according to the customs of the land."20

In dozens of interviews in Maubara over the course of several years I have not been able to find any indication that the Doutels intense engagement with the VOC during the second half of the eighteenth century has survived in the oral tradition. And yet, there are two rather obscures way in which the Doutel's alliance with the VOC may be encoded in fragmentary form. The first of these involves the bizarre oral account that a man named Barnado from the original settlements of Ikolau and Kaisave tapped a book three times to appoint the incoming Portuguese governor in Dili. 
The known genealogy suggests that Barnado was a contemporary of Dom José Xavier Doutel, and hence lived in the late eighteenth century. The "judicial” function ascribed to the autochthonous houses of Ikolau and Kaisave in oral accounts of the Loro Liurai appears to be to be transposed, but may refer to their role in supporting Dom Paulo and others who sided with the Portuguese. It appears, therefore, that with the Portuguese move to Dili and renewed efforts to woo polities in the eastern part of island, partially overlapping cleavages within Maubara resurfaced and coalesced in a split between the Doutels of Guguleur, who remained loyal to the VOC, and the descendants of the first stranger king in Vatuvou together with nonruling houses in Ikolau and Kaisave, who sided with the Portuguese.

There is a second way the history of the VOC in Maubara is retained in the oral tradition and relates directly to the murder of Mau Kuru in I999. VOC documents reveal that visits by VOC officials to Maubara and by members of the Doutel family and entourage to Kupang were occasions for the exchange of gifts and trade goods. This included not only firearms and gunpowder, but also gifts symbolizing rule and vassalage such as the Dutch flag, canes of office, and colored beads. ${ }^{21}$ It is the last of these-whether from the earliest Portuguese exchanges or the intense Dutch interaction of the mid-eighteenth century-that survived as family heirlooms. ${ }^{22}$ And in I999, as we will see, it was family heirlooms that Mau Kuru made such an effort to hide and were the immediate reason that he was singled out for murder by a distant relative working for the Indonesian state.

\section{Whales and Ducks}

The early nineteenth century in Timor was marked by two major developments that paradoxically resulted in Maubara being more deeply integrated into international networks of trade but at the same time enjoying greater independence from foreign claims. The first of these developments was the Napoleonic Wars in Europe. When French troops invaded Portugal in I807, the ruling House of Bragança only narrowly escaped, thanks to British naval support, across the Atlantic to take up residence in Rio de Janeiro. On the other side of the world, meanwhile, English troops occupied the Netherlands Indies from I8Io until I8I6. ${ }^{23}$ Benefactors of the "ancient alliance" with London, the Portuguese retained possession of Dili and the 
eastern half of Timor, but without reliable shipping their hold became even more precarious and the administrative presence shrank back to a few points on the north coast, much as it had been a century before.

Disputes over colonial claims on Timor resurfaced during the British occupation of the Netherlands Indies. In I8I2 the Dutch dispatched a man named Andries Christian Müller to travel to a number of polities in order to inform their rulers about the change from Dutch to English control in the region. The Portuguese commanders in Oecusse and Batugade warned Müller and his Chinese captain against going to Maubara, even threatening that if the captain did go there his ship would be seized and his head cut off. Later that year an English officer named Charles Lambertus reported on an official meeting held in the Portuguese border garrison of Batugade at which the discussion focused on the ongoing dispute between the European authorities in Kupang and Dili over Maubara. ${ }^{24}$ Whatever grounds the Portuguese advanced were unsuccessful, and Dutch claims to Maubara held and a Portuguese list of indigenous rulers in their territory in I8I5 did not include the Kingdom of Maubara. ${ }^{25}$

The second critical development during this period was the introduction of a new cash crop in Timor. When the Indies were returned to Dutch rule in I8I6, the enterprising new governors general in Batavia began to promote coffee, tea, and other cash crops in a number of new locations. In distant Timor, this resulted in the introduction of coffee in Maubara. ${ }^{26}$ In the cool upper reaches of the mountain, the soil and moisture from cloud cover were well suited to the new crop, and coffee cultivation spread rapidly. For the rulers of Maubara, the success of coffee production marked a major transition from the irregular collection of dwindling supplies of sandalwood, honey, beeswax, and tortoiseshell from points near and far to a more regular and high-value annual crop from within the kingdom itself.

Little information is available about events or rulers in Maubara during the first two decades of the nineteenth century, but by the I83os the ruler of Maubara was an individual known to the Dutch as Dom Cleto II, who is referred to in oral tradition and in documents from late in his life by the name D. José Doutel. Cleto II first appears in an I832 manuscript by Emmanuel Francis, who gathered data on the rulers and populations of the kingdoms in the Dutch possessions on Timor. Francis compiled a list of eight nobles within Dom Cleto's kingdom and the populations they 
controlled, totaling thirty-seven thousand souls. ${ }^{27}$ The five localities that can be identified-“Dayeer" (Daire), "Lessa Dela” (Lissadilla), "Goe Gleloe” (Guguleur), "Morai” (Morae), and "Batoe Borong" (Vatuboro)-match the geography in the origin story of the Loro Liurai.

With the waning of the Dutch and Portuguese presence, a few highly negative reports appeared about Dom Cleto II and his kingdom. Francis commented that "the Chinese of Kupang are engaged in some trade here, but the place is void of any control." A decade later the Dutch bureaucrat A. G. Brouwer described Dom Cleto II as a tyrant who had murdered his brother and mistreated merchants and subjects alike. ${ }^{28}$

During this period an altogether new breed of visitor made periodic appearances in Maubara and other settlements on the north coast: English and American whaling ships. The Timor Strait (as the Alor/Ombai Strait was then called) was one of the finest and most famous hunting grounds, and Herman Melville's novel Moby Dick includes a fleeting reference to a sperm whale named "Timor Tom," famous for attacking ships. Melville, in fact, had served on a whaling ship that hunted in the Timor Strait, after which it called at the small bay of "Batta Gatta" (a misspelling of Batugade), site of the Portuguese border garrison and occasional missionary activity. ${ }^{29}$ Whaling ships also called at Maubara, either to make minor repairs or to collect fresh water and purchase provisions. One such visit, about which a detailed account is available from the Singapore Chronicle and Commercial Reporter, occurred in I836, and although the ruler in question is not named, we can be certain that it was Dom Cleto II.

By the arrival of the Diana [in Singapore] we were put in a possession of a statement regarding the reception of the ship Japan and bark Kingsdown when these two vessels called in February last at Point Mobar [Maubara], Timor, for the purpose of procuring refreshments for their crews. Both vessels were English and were South Sea Whalers, and upon their arrival the Chief at Point Mobar received them very kindly selling them buffaloes, sheep, goats, and poultry. The bargains being all concluded the commanders of both vessels and their surgeons were invited to dine with the Chief, who, it is said, exhibited the utmost good humour and friendliness during the repast, apparently pleased with the profits he had made with the strangers, until his satisfaction 
was somewhat disturbed by his being asked to deliver two goats which were still due. After some hesitation it was agreed that two sheep should be taken for the two goats, but no sooner had they been placed in the boat than they were instantly demanded back and goats delivered in lieu. To this time every thing appeared amicable between all parties when the ships boat left the shore, with the two commanders in one of them, to proceed on board; but they had only gone a very short distance when the natives were observed to make a sudden rush from the beach to their huts, and from the latter back to the beach, when they commenced a heavy five [sic, fire] of musketry upon the two boats which were at the time quite unprepared and unarmed to encounter such treachery. We regret to add, however, before the boats were out of reach of the fire of these wretches, that Captain William Simmons of the Kingsdown and S. E. Aldwell, the carpenter of the Japan fell victims to this unexpected and diabolical perfidy. ${ }^{30}$

The chief's enthusiasm indicates that he was not all surprised by the arrival of foreigners who were neither Chinese nor Makassarese, Dutch nor Portuguese. He was accustomed to trading with just about anyone-including whalers-who called at his modest beachhead, but was also willing to use force to ensure that trade took place on his terms. The second notable feature of the incident is that neither the newspaper account nor the diary of the ship's surgeon makes mention of a Dutch flag flying above Dom Cleto II's palace (the old VOC-built fort) or, for that matter, the presence of any Dutch officers or soldiers. In fact, in a follow-up story the Singapore Chronicle and Commercial Reporter noted that the Dutch government in Batavia denied that the "natives" of Maubara were its subjects. ${ }^{31}$ Dom Cleto II may have retained his allegiance to the Dutch, but during this period he seems to have operated with virtual autonomy from foreign overlords.

While people in Maubara today know that the kingdom was once under or allied with the Dutch-referred to as "Olanda" or "Blada"-the actual experience of the Dutch has vanished from the oral tradition. The sole exception is a story told by the elderly Mau Dua of Lauana. ${ }^{32}$ One day, he explained, the Dutch commander caught several slaves who had stolen some of his ducks. He threatened to cut off their hands, but before he could do so the slaves escaped. This led to some sort of trouble-either the commander took out 
his anger on innocent people or the populace rose up in protest over his heavy-headed threats. Details are lacking, and it is unclear why this particular incident (for there must have been many similar cases over the years) has been passed down in oral tradition.

The absence of external involvement in Maubara in the I830s and I84OS opened the way for internal fissures to again surface between the leading families in Maubara. Although lacking in details, the available sources suggest two competing versions of events. According to a Dutch report, Dom Cleto II treated the populace of Maubara and foreign merchants with great brutality and was eventually expelled from the kingdom. He then offered slaves to the ruler of Oecusse in return for assistance in reclaiming his kingdom, but his ship was impounded by the Portuguese garrison in Batugade. Dom Cleto II made further appeals for assistance but without apparent success. Oral histories collected in Maubara suggest a very different account. At about this time, sources say, Dom Carlos of Vatuvou was involved in a war on the island of Alor, which was officially Dutch territory but disputed by the ruler of Oecusse. After a victorious campaign, Dom Carlos returned to Maubara with a large number of slaves and became the most powerful figure in the kingdom. ${ }^{33}$ Although told from different perspectives, these accounts suggest that during the I840s the balance of power within Maubara was reversed, with Dom Cleto II losing much of his authority and Dom Carlos of Vatuvou emerging as an independent power. ${ }^{34}$ Once again, local cleavages identified in foundational narratives resurface when the constellation of supralocal actors underwent change, leading to new forms of violence.

\section{Pawns in Their Game}

Maubara's fortuitous alliance with the VOC was forever ruptured in the middle of the nineteenth century. Recognizing the need for a new approach to its most distant colony, in I850 the Portuguese government in Lisbon made the Solor and Timor islands an autonomous territory and appointed José Joaquim Lopes de Lima, who had previously headed the administration in once golden but now decrepit Goa, the new governor. Upon his arrival in I85I, Lopes de Lima immediately understood that the colony's already precarious economy was undermined by rampant smuggling into Dutch territory and the regular but unwanted visits of Makassarese ships to both 
trade and raid. ${ }^{35}$ His solution was twofold: formalize the borders with the Netherlands Indies and establish a functioning customs regime. Without consulting Lisbon, the governor entered into an agreement with Dutch officials in Kupang and Batavia to demarcate the border and exchange the Portuguese claims to parts of Flores and the string of islands running from Solor to Alor in return for the Dutch claim to Maubara and the modest sum of two hundred thousand Dutch florins. ${ }^{36}$ Two features of the agreement are particularly noteworthy. First, the list of polities involved in the transfer of territory notes that Atasabe, Deribate, Hermera, Leimean, and Mahubo (all in the present-day district of Ermera) were "under" Maubara. Second, the agreement specified that the coastal polities to be exchanged included not only Maubara, but also "Batǔborong, Nǔssadilla, and Daïr of Laukero," the three localities that in the legend of the Loro Liurai had been selected to serve as "assistants" to the founder of the Doutel line.

When word of the exchange reached Portugal, officials in the Ministry of Overseas Affairs were outraged by what appeared to be a highly unequal territorial swap. Lisbon sought to remedy the disaster in I852 by abrogating the autonomous status of Timor and placing the territory directly under the Portuguese enclave of Macau. A new governor was appointed and the disgraced Lopes de Lima was recalled to Lisbon, though fled to Batavia, where he died. In I854 a new Portuguese-Dutch border treaty was signed, but the Lower House of the Dutch Parliament rejected the treaty the following year on grounds that it failed to protect the freedom of religion of the indigenous population in those areas being transferred to Portuguese authority. ${ }^{37}$ In 1859 a third treaty was signed between the colonial powers formalizing Lopes de Lima's original territorial exchange. ${ }^{38}$ With this, Maubara's ties to Kupang and the Dutch were to be severed and the kingdom was to come under Portuguese sovereignty.

Territory was one thing, people something else altogether. While final negotiations between Portugal and the Netherlands were still under way in early I859, the Dutch resident in Kupang began to make preparations for the anticipated transfer of territory. He instructed L.W.A. Kessler, his subordinate posted in the port of Atapupu, near the border, to brief the "rajah" and the various chiefs of Maubara about the new treaty. Kessler, in turn, sent a message via a missionary requesting the chiefs' presence in Atapupu. However, Kessler later wrote, "Dom Joseph [José, alias Cleto II], the rajah of 


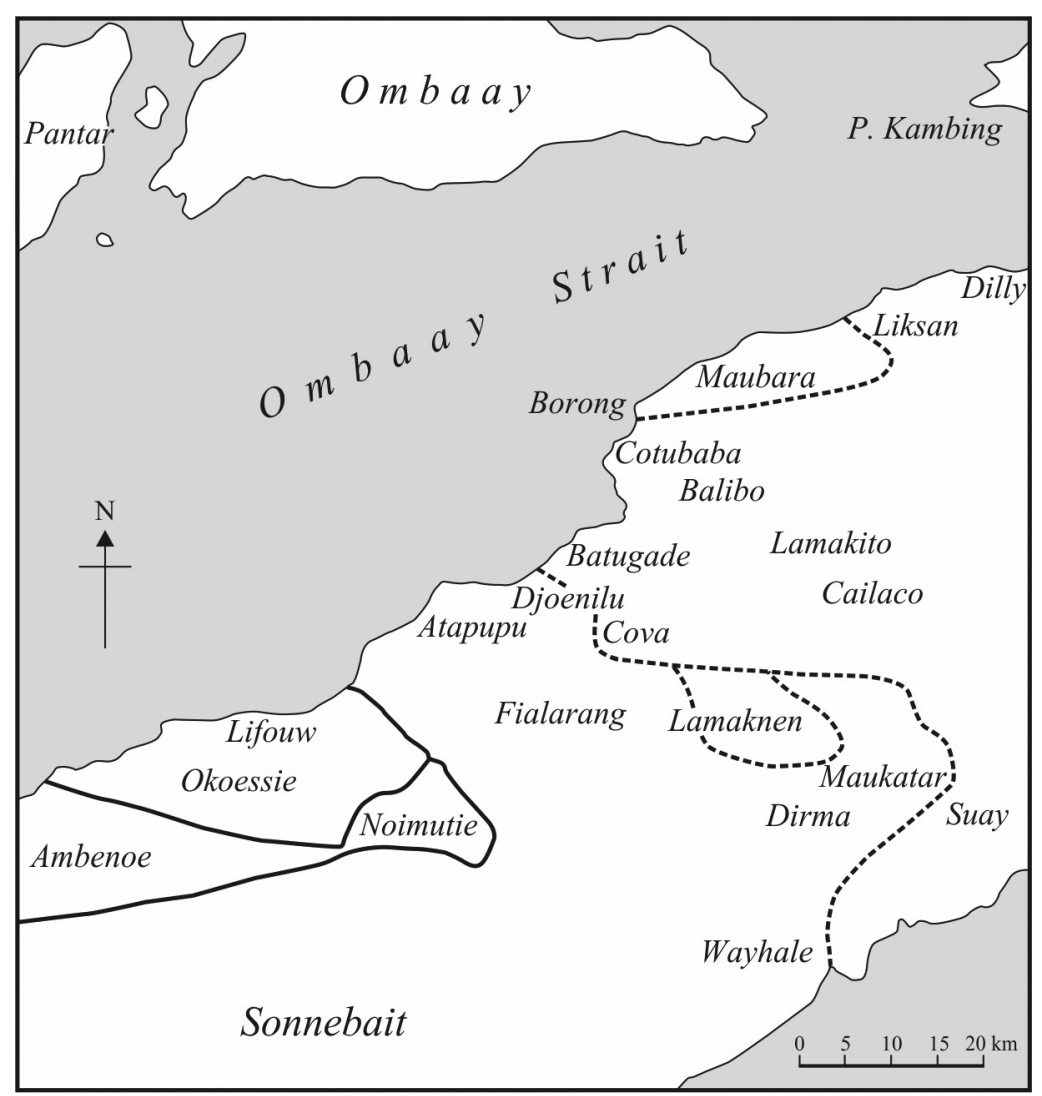

MAP 2 Map from I85I agreement between Portugal and the Netherlands showing Maubara and neighboring polities (redrawn from original)

the empire, was ill [in fact, paralyzed] and had a conflict with the neighboring hamlets, so wanted to apologize" for not being able to attend. ${ }^{39}$ The party that traveled to Atapupu included Dom Carlos of Vatuvou, who Kessler wrote "had the greatest authority," Dom José's son Nagabata, the chief trader Datoe-Lau, ${ }^{40}$ and a "raja" named Mau-Lay. ${ }^{41}$ Kessler later wrote,

I decided to cut the Gordian knot and to inform them of this order. As a consequence, a meeting was organized at my house. After having talked about superficial matters, I took the map and indicated the borders of middle-Timor; the location of Timor-Kupang; and the location of their own kingdom; I also indicated to them that Maubara was totally surrounded by Portuguese states, and also 
indicated the great distance of the capital and Atapoepoe and I indicated that it was necessary to settle this problem.

After having explained it all and having made it comprehensible, I then went on to inform them about the government's decision; I discussed with them the pros and cons and made it clear that the surrender happened not because the Netherlands had something against them, but only in order to get a border separation in due course. They would remain friends of the government and that they would receive later on a token of this friendship, provided they would subject themselves to the wills of both governments. Resistance would bring only unhappiness for country and population. Hence it was strongly recommended that they obey and follow the orders of the Governor of Timor-Dilly, because if they would not obey their kingdom would undoubtedly be occupied by force of weapons. ${ }^{42}$

After some discussion, the chiefs in attendance told Kessler that they would acquiesce only "with great reluctance because they were more devoted to the Dutch government." They had "grievances" (including cruelties committed by the Portuguese in the past), and "preferred not to have to pay tribute." The following day, having been summoned by the missionary, the Portuguese military officer in Batugade came to Atapupu, but informed Kessler that he had not received any instructions and therefore could not make any decisions. That afternoon, the chiefs from Maubara again said they would comply but requested the opportunity to "write down the grievances that they had and to hand over a copy so that when necessary they could make use of this." ${ }^{43}$

Kessler and a party of nobles from Maubara then traveled to Dili to meet with the interim Portuguese governor, Major Cabreira, and make arrangements for the ceremonial transfer. In Dili, Kessler stayed at the governor's residence while the chiefs lodged at the home of a Chinese merchant. Major Cabreira explained to Kessler that he had not received any instructions from Lisbon regarding the procedure for the territorial transfer, but nevertheless agreed to cooperate. In his subsequent report, Kessler described the formal ceremony at the governor's residence: “The provisional governor read out my minutes; this act and the decision planned were registered in a minutes book and signed by all of us. Subsequently a twenty-one gun salute was fired, the Portuguese flag was handed over to the chiefs and it was decided that I 
would go with an officer to Maubara in order to receive there, according to customs, the Dutch flag and have the Portuguese flag hoisted." ${ }^{44}$

Late that day Kessler departed from Dili by boat, arriving in Maubara early the following morning in stormy weather. Upon reaching land, Kessler was mobbed by the chiefs and populace, who created a "great agitation." There was still strong opposition to the territorial exchange. Kessler discussed their grievances and offered further reassurances that the transfer was in fact in the best interests of the kingdom and its subjects. Dom Carlos and his retinue, having returned overland, reached Maubara in the afternoon. With all parties present, Kessler and his Portuguese counterpart then presided over the flag ceremony. "It was hoisted and let down by me three times, every time saluted by a gunshot from the ship St. Antoine, and afterwards also by the Portuguese flag, which, under the [canon] salute of that ship, the third time remained on the pole." Gifts were then dispensed. Kessler gave a Dutch flag to Dom Carlos as "a token of friendship." The Portuguese representative also passed out presents "consisting of sarongs, headwear and arak [palm liquor].” The ceremony complete, Kessler boarded his ship and departed quickly, leaving the kingdom and people of Maubara under new masters.

Kessler's detailed description of the territorial exchange provides a few new pieces to the larger puzzle concerning the fate of the Doutel family. First, the exchange of gifts was a central component in indigenous relations with the Europeans, and some of these items were carefully guarded as sacred objects. Ceremonial respect for the flag loomed large in these relations, the legacy of which remains throughout East Timor today. Second, despite reassurances that the Portuguese would not mistreat their new subjects, the rulers of Maubara strongly opposed paying the annual "tribute" and wished to maintain their long-standing practice of free trade that was dependent upon the network of Chinese merchants connecting Maubara to Atapupu and Kupang and on to international markets. ${ }^{45}$ What Kessler's account does not say, but is remembered in family stories, is that at the time of the territorial exchange the Dutch administration took D. José Doutel's youngest sister, Dona Emelia, with them and arranged for her to be married to the ruler of a polity in the vicinity of Kalabahi, on the island of Alor. ${ }^{46}$

The ceremonial change of flags in Maubara had taken place without incident, but the territorial transfer was not yet complete. It was not until August I86o that the Portuguese and Dutch Crowns finally ratified the treaty, 
to take effect the following year. ${ }^{47}$ To this end, in March I86I Portuguese governor Affonso de Castro called on the Dutch administrator in Atapupu to summon the nobles of Maubara, including Dom José's son Nagabata and Dom Carlos of Vatuvou, and convince them to submit, which they did. ${ }^{48}$ The following month, however, with Governor Castro on administrative leave in Java, rebellion broke out in kingdoms to the east and west of the capital. Portuguese troops first quelled the rebellion in Laclo, to the east, and later in the year turned their attention to the west. Dom Carlos of Vatuvou lent troops to participate in the military operation, but his brother, Datu Lau, and in all likelihood members of the Doutel family as well, had joined the maquis. After suppressing the uprising in Ulmera, Portuguese troops marched along the coast to Maubara town and then continued on to Vatuboro, which was, in Governor Castro's words, “reduced to obedience.”49

Thirty soldiers were then posted at the newly established military command, ostensibly to guard the customs house but in fact to secure compliance from the Doutels and their longtime loyalists in other hamlets. The reality was that Dom José Doutel, the aged (and according to some accounts paralyzed) ruler of Maubara was unwilling to submit to the governors in Dili and continued to fly the Dutch flag. According to oral tradition, conflict soon arose between Dom José Doutel, who continued to occupy the old fort in town, and Dom Carlos, the head of the ruling family in Vatuvou, ${ }^{50}$ who the Portuguese had appointed as the new régulo (Little King). ${ }^{51}$ One night Dom Carlos and his men staged a surprise attack on the fort and captured Dom José, whom they turned over to the Portuguese authorities. Imprisoned in Dili, Dom José swore that he would return home and reclaim his family's kingdom. Never seen again, he is remembered in a couplet:

Dom Cleto Maubara, Dom Maubara

Sai hosi Dili, Dom Maubara
Dom Cleto of Maubara, Ruler of Maubara

Went to Dili, [whither] the

Ruler of Maubara

\section{Conclusion}

The Kingdom of Maubara enjoyed its greatest prestige during the second half of the eighteenth century when Dutch officials made regular visits to 
the kingdom and members of the Doutel family received royal regalia and letters, traveled to Kupang, and even corresponded directly with the VOC governor general in Batavia. During this period Maubara was the center of a regional network of polities under Dutch sway, and its rulers exerted influence across the Ombai Strait to the eastern portion of Alor as well. And yet all that remains of this history today is knowledge that Maubara had once been under the Dutch, an imposing fort and a quaint whitewashed church, and a rather vague story about slaves and stolen ducks. There are several possible explanations for why this history has been lost in the oral tradition. Perhaps origin stories are of greatest importance to the people of Maubara and individual rulers and specific historical events simply pale in comparison. It is equally possible that the recurrence of mass violence over the next century and a half disrupted the transmission and maintenance of this glorious past. I suspect, however, that a third dynamic may have been at work: the period of Dutch suzerainty and the Doutels' power waned in the oral tradition because they do not fit within the imperial narratives promoted by the Portuguese during late colonial rule or the nationalist narrative that took root in 1975 and has been reinforced since I999 of 450 years of Portuguese colonial rule. A century of allegiance to the VOC made Maubara a historical anomaly.

That Maubara's heyday is no longer part of the oral tradition does not mean it was unimportant to subsequent generations, or that this history cannot inform our understanding of how the people of Maubara responded to subsequent episodes of conflict or violence. Despite their obvious limitations as sources of historical fact, both the archival record and the oral tradition suggest that the divisions embedded in the foundational story about indigenous authority prior to the eighteenth century continued to inform local responses to the colonial rivalry between the Portuguese Crown and the VOC, and were played out in the reversal of fortunes of the royal families in Guguleur and Vatuvou. While macro-level approaches to Timorese history have tended to treat the indigenous polities as unitary actors, Maubara's history suggests the need to pay far greater attention to how and under what conditions internal divisions and rivalries produced variation in responses to supralocal actors, ideas, and events. 


\section{Vassalage and Violence, 1861-1887}

$\mathrm{B}$ etween the I86os and mid-I880s successive Portuguese governors in Dili did what they could, given the limited European manpower, irregular shipping, and budgetary dependence on Macau, to develop a functioning state apparatus and assert authority over the myriad Timorese kingdoms in the territory. The success of colonial expansion was far from ensured, however. Where colonial regimes engaged relatively coherent indigenous states that enjoyed legitimacy and some administrative capacity, as in central Java, traditional elites could be co-opted into collaboration under forms of direct colonial rule. Elsewhere, as in the coastal sultanates in the Netherlands Indies and British Malaya, colonial state builders opted for variants of indirect rule whereby traditional elites traded subservience to external authorities in return for real increases in their power over the surrounding population. ${ }^{1}$ Within Portuguese Timor there was significant variation in the impact of colonial rule and elite responses during the second half of the nineteenth century. Polities that had sided with the white governors in the early eighteenth century often continued to cooperate closely with the Portuguese authorities in Dili, but other polities resisted such a role or, in the presence of a new supralocal center of power, experienced internal fissures and challenges.

The enterprising Governor Affonso de Castro drew up grand plans for administrative reforms and economic development in the colony, with the newly acquired Kingdom of Maubara seen as both a key source of revenue and model for the promotion of cash crops. In the early I86os officials 
in Dili estimated that Maubara had a population of 138,500 people, an astronomical figure that suggests not only how little the Portuguese knew about their new possession but also the high hopes they had for the kingdom. ${ }^{2}$ Although the strength of the Portuguese garrison in the coastal town of Maubara increased, neither the colonial regime nor the traditional elites through whom they ruled enjoyed a corresponding improvement in administrative capacity over the many scattered hamlets. Furthermore, the century of alliance with the Dutch had left the Doutels and their followers deeply hostile to the Portuguese and the newly ascendant Dom Carlos of Vatuvou. The combination of colonial interest in coffee cultivation and fissures within the local elite made Maubara a lawless place filled with accusations of witchcraft and physical threats, robberies, and murder, which under the right conditions could escalate into open conflict between competing ruling houses and even armed resistance against the Portuguese regime.

This chapter examines the "troubles" in Maubara during the quarter century from I86I until I886. Both the sources and forms of violence during this period varied greatly. While the indigenous population engaged in theft, murder, and at times even limited raids against Portuguese installations, the colonial regime responded by posting permanent military forces and even launching full-scale military assaults that included the indiscriminate burning of indigenous settlements. The chapter also highlights shifting indigenous representation and leadership within the Portuguese system of indirect rule, showing that despite the recognition of kingdoms Portuguese policy served to heighten rivalries among the leading families of Maubara and at times between them and neighboring polities. Finally, the chapter narrates how the Doutel family and their supporters unwittingly became entangled in the greatest outrage against Portuguese authority: the assassination of Governor Maia in broad daylight on the streets of the capital, Dili.

\section{Two Decades of Trouble}

We are fortunate to know about some of the "troubles" in Maubara during the two decades after the territorial transfer because in I886 Governor Alfredo de Lacerdo Maia, concerned to understand the ongoing 
rebelliousness of the kingdom, consulted "the existing communications in the archive of the secretary" in Dili and included brief summaries of what he found in a report sent to Lisbon. The records Governor Maia examined went back only to 1867 because the year before that a massive fire in Dili destroyed a number of government buildings and the colonial archive was lost. ${ }^{3}$ Needless to say, what Governor Maia found and the brief notes he forwarded to Lisbon provide details of what the administration deemed noteworthy-which was primarily disorder and violence-but are silent about the indigenous populations' views of their own world, their motivations, and how colonial power transformed the polity.

In January I867, the Portuguese commander of the fort (presidio) in Maubara, an ensign named Curado, summoned the régulo, Dom Carlos of Vatuvou, threatening that if he did not come to the presidio Curado would "go kill him." Despite the threat, Dom Carlos refused. A month later, Curado reported a "serious disorder in the bazaar in which there were 3 dead and 2 wounded; things that happened under our nose in the presidio, under the shadow of our flag, with great inconsideration for our authority." This was followed by further acts of aggression in July, when Dom Carlos faced down a Portuguese force sent to arrest an unnamed criminal, and in September, when a Portuguese officer on his way to the garrison at Batugade was attacked in the hamlet of Daire. ${ }^{5}$ Unfortunately the archival sources do not explain why Dom Carlos, who at the time of the territorial transfer had sided with the Portuguese, had come to oppose the colonial regime; nor do they specify the reasons for these incidents. Nevertheless, it is clear that Dom Carlos and much of the populace remained openly hostile to the new white masters.

A new dispute broke out in about 1870, this time between Maubara and the neighboring Kingdom of Liquica, which was historically among the most loyal to the Portuguese governors. ${ }^{6}$ Portuguese sources do not specify the causes of the dispute, though one author has suggested that this may have been related to the rebellion that year centered in the kingdoms of Cova and Cotubaba, located near the border with Dutch Timor. ${ }^{7}$ According to oral accounts, the conflict between Maubara and Liquica was over ownership of twelve Chinese porcelain plates, though porcelain (which Timorese elites did own and often kept in their lineage houses) may have been only a minor component of the differences or even a latter 
euphemism for the real point of conflict. In fact, we can be quite certain that the real cause of the dispute was trade, and quite likely the illegal smuggling of goods from (and through) Liquica into Maubara, from where they were exported to Dutch-held Atapupu. ${ }^{8}$ For despite the territorial transfer, the Doutels and other lesser nobles once allied with the Dutch were intent on maintaining their long-standing practice of free trade. They openly resisted Portuguese efforts to curtail the movement of goods from the interior through Maubara as well as the new customs imposed on the coffee produced in the kingdom.

At the time of the conflict between Maubara and Liquica Dom Carlos of Vatuvou died, and perhaps not of natural causes. ${ }^{9}$ Soon thereafter the Portuguese authorities in Dili arranged for the nobles of Maubara to participate in the "election" of a new régulo. This resulted, in January I872, in the elevation of Dom Carlos's nephew, Dom Dotte, as the new regent of Maubara. ${ }^{10}$ The appointment of a new régulo did little to calm the situation, however, and conflict among leading families in Maubara and between Maubara and its neighbors continued to simmer. These tensions were sufficiently serious that in late I872 the Portuguese authorities in Dili formally requested that the Dutch resident in Kupang intervene-in all likelihood with their old allies the Doutels of Guguleur-to help settle the dispute. No details are available about the Dutch response or Portuguese negotiations with the two kingdoms, but a peace agreement was finally signed in August I872. ${ }^{11}$

Peace agreement or no peace agreement, Maubara was entering a new heyday of trade. At the center of this lay the cultivation of coffee. From the time of Governor Affonso de Castro, who was a keen observer of the Dutch system of forced cultivation in Java, Portuguese colonial officials had made repeated calls for the development of coffee as an export crop. Scholars have argued that indigenous smallholders, not large Portuguese planters, were the moving force and responded to market forces independently of the official encouragement and orders to plant trees and deliver set quantities of coffee to the state. ${ }^{2}$ Maubara, where suitable land was plentiful and seedlings as well as shade trees grew rapidly, was at the forefront of coffee cultivation. In I863-I865 Maubara accounted for 53 percent of coffee exports from Portuguese Timor, and in the I87os it remained the largest producer of all the kingdoms. ${ }^{13}$ 
Hakka sojourners from China seem to have played a significant role not just in the export of coffee but in its cultivation and processing as well. Several of these individuals can be identified, and are worthy of detailed consideration.

According to oral accounts, the first Hakka merchant to reside permanently in Maubara was a man with the surname Lay (possibly the “Mau-Lay" mentioned in Kessler's account about I859). He obtained land in Erito, a hamlet situated in a small hollow below Lauana, surrounded by steep terrain, where with the help of local labor he cleared land and established a plantation. Lay's son, who may have been born in China and then traveled to Timor to join his father, was named Lay Anyi. Through his father's connections in Guguleur, Lay Anyi married Dom Repreto's daughter, Bui Kura. This is the woman-probably born sometime in the I850s-who is commemorated on a black gravestone in the Lissalara cemetery as "Avo Kura Fatima Lai" with the fanciful lifespan of more than two centuries (I4I5-I660). Lay Anyi was clearly a prominent merchant, for after the turn of the century his name appeared repeatedly in the colonial gazette in connection with the purchase of land and his appointment as head of the Chinese community in Maubara. At some point two other Hakka men joined the Lays in Erito, where they also started coffee plantations and built simple homes. ${ }^{14}$ One of these men may eventually have married Dona Maria Doutel, the younger sister of Dom José Doutel, whose first husband had been "sent away" for failing to pay the necessary bride price..$^{15}$ For these Hakka sojourners, close ties to the Doutels facilitated access to land and protection.

Many more Hakka sojourners soon poured into the town of Maubara, making it a virtual "Chinese" enclave. ${ }^{16}$ As was the case elsewhere in Southeast Asia, far more men than women made the journey from China to Timor, so at least some of these men must have taken local wives. The Hakka opened shops, but much of their business was conducted traveling to the various hamlets in Maubara as well as up the Loes Valley to sell imported goods, including opium, ${ }^{17}$ and to buy coffee beans and other produce for resale in the towns or for export. While the Lays were on close terms with the Doutels, the business activities of many other Hakka merchants encroached on the ruling family's long-standing control over local trade. 


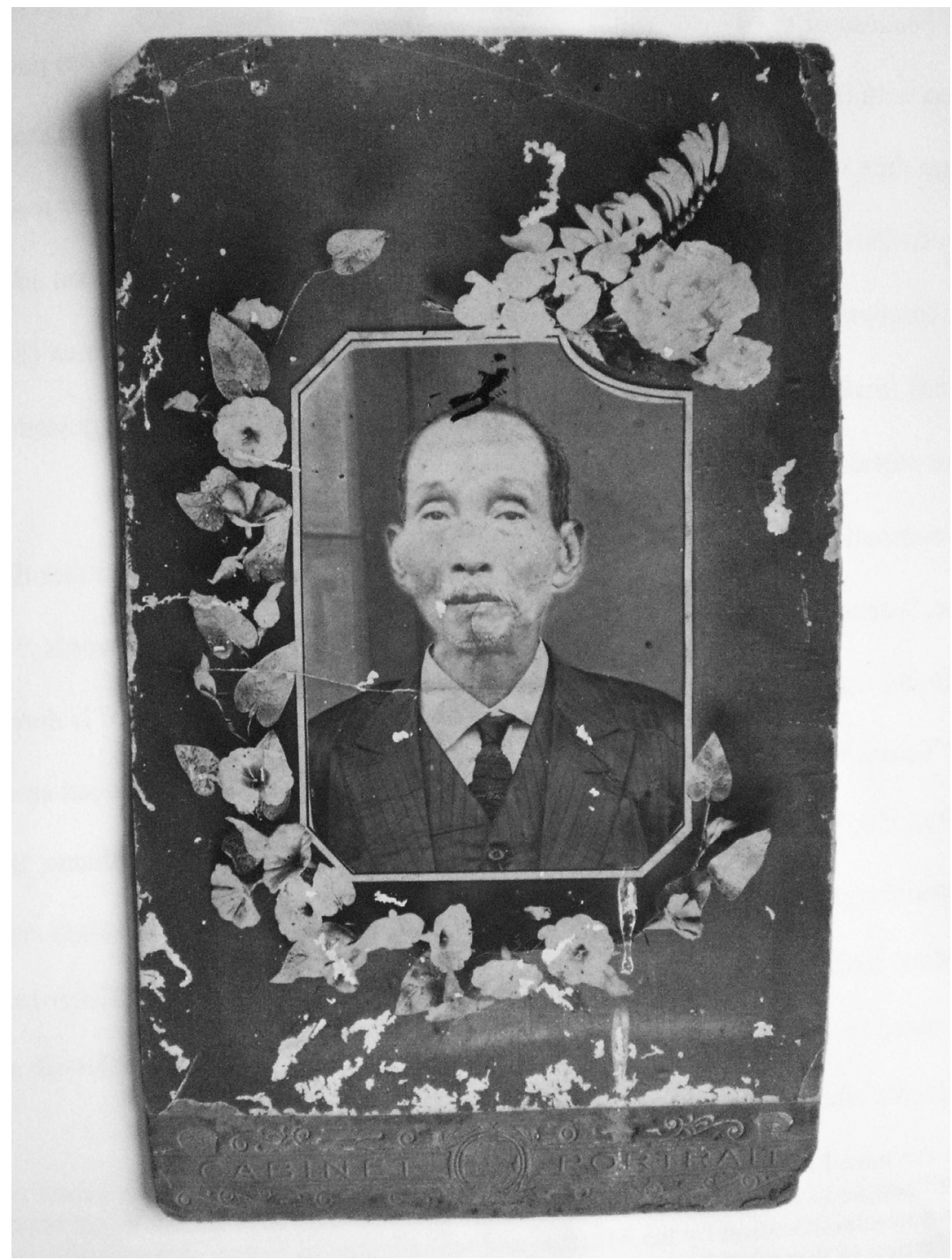

FIGURE 4 Lai Anyi, a Hakka merchant in Maubara, ca. I9oo (courtesy of Afonso Lai)

State efforts to control the sale of coffee and collect export duties only deepened opposition and friction within Maubara, and the state of lawlessness persisted. In I876, for example, Lieutenant José dos Santos Vaquinhas, a Portuguese military officer with extensive experience in Timor, complained about "the disorder between [the coffee growing hamlet of] Babequenia and an individual named Areberra, from which resulted many 
deaths." In a report later that year Vaquinhas expressed outrage that "the régulo sent someone to kill a I7-year-old boy named Mau-Lado-in front of the presidio!-for engaging in witchcraft." 18 The Portuguese authorities needed to find new ways to bring order to the valuable kingdom.

The strategy adopted by the governors in Dili was to intensify the longstanding policy of vassalage. In early I877, recently arrived Governor Joaquim António da Silva Ferrão pressed the Kingdom of Maubara to renew its terms of vassalage and oath of loyalty. This was a standard procedure, and by all appearances each new governor attempted to sign such terms with as many of the kingdoms as possible so as to establish personal ties and rapport with the local rulers. In the case of Maubara, the I877 terms are particularly revealing. The document was signed by D. Nocolau, who is listed as a principal (a member of the ruling family) ${ }^{19}$ with the rank of lieutenant colonel, in the name of the ruling queen (rainha). ${ }^{20}$ The queen in question was Dona Maria Doutel, sister of D. José Doutel, who had been detained and then disappeared after the I859 territorial transfer. ${ }^{21}$ In I877 she would most likely have been about sixty years old and was married to her second husband, one of the Hakka coffee planters mentioned above. D. Nocolau was one of D. José Doutel's sons, and hence Maria's nephew, whose given name may have been Calau Asa (and later José Calau) but who is also remembered in oral accounts by the traditional title Cleto. ${ }^{22}$ It is not clear why the Portuguese decided to recognize Dona Maria Doutel as the ruling queen, though female rulers were in fact common in the territory claimed by the Portuguese throughout much of the nineteenth century. ${ }^{23}$ She might have been chosen as queen simply because she was the oldest living member of the Doutel family, but it is equally possible that she was selected in the hope that a female ruler would be weak or acquiescent to Portuguese authority.

What is most striking about the I877 terms of vassalage is that they included three men with the title Dom: D. Nocolau from Guguleur; D. Gaspar da Costa (the Christian name of D. Dotte, who was elected ruler in I872) from Vatuvou, who is listed as a principal and tenente coronel; and D. José Rodrigues (better known by his Tokodede name Mauvili) from Raelete, who is listed as a sargento-mor (sergeant) in the indigenous secondline colonial military. ${ }^{24}$ This suggests that the Portuguese were attempting to give official recognition to both lineages descended from stranger kings 


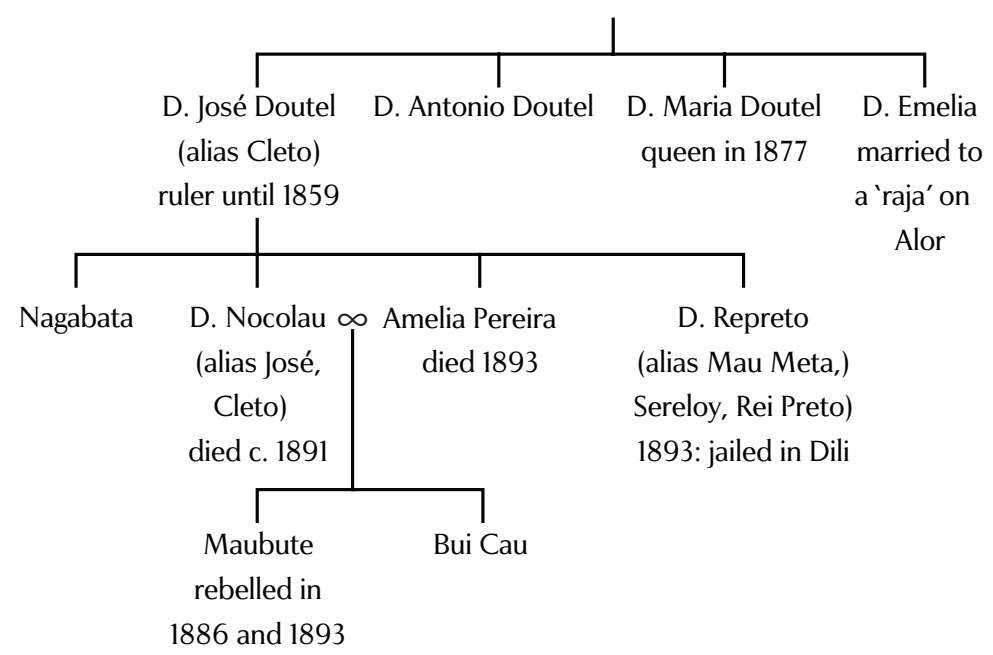

FIGURE 5 Doutel lineage, late nineteenth century

from Suai Loro who had formed ruling houses in Vatuvou and Guguleur, and at the same time to promote an individual who claimed descent from one of the autochthonous settlements that in local lore had ceded power to the stranger kings.

No sooner had the i877 terms of vassalage been signed than new outrages were committed in Maubara. In I878, a Portuguese ensign named Esteves reported that "the people of the kingdom were attacking and robbing Chinese houses and threatening to attack the presidio. On the following day, this official recorded on three sheets of paper the robberies against the Chinese houses, which were ransacked, and noted that it was necessary to prepare to defend the fort." ${ }^{25}$ To staunch further attacks, Esteves requested three hundred men be sent from Liquica to help defend the town. It is necessary to emphasize that during this period the Portuguese presence in Maubara was very limited, essentially restricted to the town of Maubara itself. A Portuguese document from I878 listing all military personnel in the colony shows that the detachment in Maubara consisted of one ensign (alferes), a quartermaster (furriel), two corporals (cabo), and five soldiers (soldados), while the customs post was staffed by a first sergeant and six more soldiers. ${ }^{26}$ Furthermore, there was virtually no missionary presence in Maubara: between I877 and I886 the only known activity by Catholic priests in Maubara was the baptism of twelve children 
in $1885 .{ }^{27}$ With such a limited Portuguese presence, this was still indirect rule and the authorities had no choice but to rely on the cooperation of indigenous elites living in the upper reaches of the mountain.

Four years later, in June I88I, Maubara was required to sign terms of vassalage yet again. This time, D. Nocolau, who four years earlier held the rank of lieutenant colonel and signed on behalf of Queen Maria, took the oath of office under the name D. José Nocolau as the new "brigadeiro reino do reino de Maubara" (king and brigadier of the Kingdom of Maubara). The new ruler's authority was undercut, however, by the appointment of D. Gaspar da Costa, who in I872 was made regent and in I877 was a Dom, as the "coronel regente de Maubara" (regent and coronel of Maubara). ${ }^{28}$ Neither the written records nor oral histories provide an explanation for this dual arrangement involving a "king” in Guguleur and a "regent" in Vatuvou, but the most likely reason is that the Portuguese authorities once again were attempting to balance the claims of the rival ruling families. While the Doutels in Guguleur continued to receive symbolic recognition with the position of king and the higher military rank, D. Gaspar da Costa's appointment as regent meant that the ruling house of Vatuvou now had day-to-day authority for the maintenance of order and oversight of commercial activities.

Whatever the formal arrangements, the Doutels, other nobles and Hakka merchants continued to cultivate and process coffee, and then, evading the Portuguese customs regime, sell their valuable produce to Hakka merchants in town or in the Dutch-controlled port of Atapupu. ${ }^{29}$ They also maintained their position as a key conduit in the flows of goods-honey, wax, some sandalwood, and perhaps some slaves-down from the interior, and the counterflow of foreign imports such as cloth, metal goods, guns, and gunpowder up the watershed.

\section{The Governor's Fury}

The long-standing tensions in Maubara-pitting the local elites and Hakka traders against the Portuguese, sections of the indigenous population against the Hakka interlopers, and the rival ruling families of Guguleur, Vatuvou, and the rising young officer Mauvili from Raelete against one another-came to a head in I886. The events of June of that year must have 
come as an enormous shock to Governor Maia, for only two months before he had made a state visit to Aipello, Liquica, and Maubara. On his return to the capital, he wrote a letter to the governor of Macao and Timor in which he commented, "The presence of the governor always represents for them [the Timorese] a magic influence, even when they have been ill-treated by the [Portuguese military] commanders, and even when prior misconducts have caused them distrust." ${ }^{30}$ Distrust was putting it lightly, and grievances surely outweighed whatever "magic influence" the governor believed his presence to have.

The immediate trigger was provided in early June when troops under the command of Régulo D. José Nocolau are alleged to have murdered a Hakka man in the hamlet of Vaviquinia. D. José Nocolau and his men then marched down to the beach and "threatened to cut off the head of the major of the kingdom, one Dom Antonio, and another Timorese by the name of Assu." ${ }^{31}$ The Portuguese commander of the fort, Francisco Pedro de Mira Feijo Elvaim, promptly reported the matter to Dili. In response, Governor Maia hurriedly assembled a small force and set off for Maubara to see if he could capture the criminals. Before the governor arrived, however, D. José Nocolau and his men had made another foray down to the beach, this time threatening the Portuguese commander, who had narrowly staved off the attack by brandishing a pistol. Concluding this to be "a grave threat to our authority," and fearing that if left unpunished the situation would escalate, Governor Maia was determined to punish the rebels. ${ }^{32}$ The governor was informed that the real leader of the uprising was José Nocolau's nephew, named "Mahabuti” (Maubute). Despite it being nighttime, Governor Maia pressed his men into action.

His force consisted of twenty-nine first-line soldiers (many of whom were African conscripts $)^{33}$ with a howitzer, two hundred indigenous troops, fifty civilians, and ten more soldiers guarding provisions in the rear. Several nobles from the kingdom also joined the governor's force. The column marched up the scrub-covered lower slopes of the mountain to the first settlement, which they found virtually deserted. The governor ordered the hamlet chief, who had remained at home, to present the "criminals" and levied a fine of three thousand rupees on the local population. Before anything could be done, however, war cries rang out and the governor and his men came under fire. Maubute, who inexplicably 
was among the nobles who joined the governor's war party as a guide, had taken advantage of the darkness and boldly led an attack on the governor's force. "There was no time to lose," the governor later wrote. "I immediately ordered that fire be set to a hut and shouted for the forces to get up. To animate the always cowardly Timorese, I left with the officers, in front of the Africans, who broke with the impetuousness of lions." ${ }^{34}$ The governor and his forces advanced, the rebels retreated. In the confusion a soldier was hit by a projectile, opening "an enormous wound." In a letter sent to Lisbon, Governor Maia provided this description: "The soldiers, who entered valiantly, lost their courage either because they didn't understand me (after all they don't understand Portuguese) or because of fear, and didn't advance any further and started to retreat. It wasn't possible for me to reorganize the forces to attack again! Retreating to the first settlement, I grabbed some soldiers, inciting them to vengeance; but my efforts, aided by the officers, were to no avail." ${ }^{35}$ It took the rest of the night for the expedition to come down off the mountain, not without a variety of mishaps and more desertions, and they arrived back in the town at eight o'clock the next morning. That evening Governor Maia traveled to Dili to make new preparations, returning to Maubara the following day (I6 June). In his written account Governor Maia claims that this time he made short order of the rebels: "The enemy, more to obey the style of the Timorese than due to courage or force, descended to the beach, but paid heavily for their audacity. Without our soldiers or even the inhabitants leaving the fort, the enemy was battered, having three wounded and one dead, who by happy coincidence was the leader of this insurrection and the father of the assassins of the Chinese!"36 This was wishful thinking, for Maubute had escaped. Furthermore, Governor Maia admitted that the leading figures of Maubara-"the régulo, the coronel regent, the major of the kingdom, the major of Decidilla, and captain Arre-bere"-were still all traitors. The governor was hell-bent to launch "a general attack in these days and reduce everyone to obedience and submit them to punishment." ${ }^{37}$

In his next report to superiors in Macau and Lisbon, Governor Maia described his thinking and subsequent operations: "I wanted to engage the enemy ... so that the results would be magnificent." He concludes this memo by noting that his Marathan and African troops killed four people, 
wounded three more, and burned four hamlets. ${ }^{38}$ And there was more to come. In his third report, dated 2 July 1886, Governor Maia explains that his troops had approached a hamlet where a white flag was flying. As his men came near, however, the enemy opened fire. "Our people became incensed and also opened fire in successive waves, the pistols never stopping." Governor Maia wasted no time: "Immediately four hamlets were reduced to ashes, with everything that was within them, including provisions from the last harvest of rice and corn, the grain bins for the whole year." Exhausted, the military force then returned to the presidio. "But still I ordered that the devastation be completed, and on the 23rd and 24th all the townships were burned." Governor Maia continues, "It was my intention to forcefully impose myself on the Kingdom of Maubara, to remove their arrogant leader, humiliate him and conclude the peace within a few days, in order to avoid harming the pending coffee harvest, which could also result in harm to the customs house." 39

On the last day of operations Governor Maia compelled régulo D. José Nocolau to sign a formal peace accord. The first article of the accord stated, "The lands, gardens and plantations of Babequinia would continue to belong to the government and no one could establish themselves there." The second article read, "The kingdom of Maubara gives to the Government 3,000 rupees for the three chiefs of the rebellion who had escaped." A subsequent condition required that the people of Maubara construct a road from the coast to the highest point in Vaviquinia. ${ }^{40}$ The governor was particularly pleased with the seizure of land:

But the best of all that happened was the possession of the lands of Babequinia, that I took over immediately as Lands of the King (Terras de El-Rei). These are not only the best plantations in Maubara, producing a profit of 500 piculs of coffee, or 2,000 arrobas, with possibilities of even more; but we can extend our dominion to the interior, whereas up to now we had only occupied the littoral. I am thinking of immediately building a fortress on the old hamlet of Nuno-Ana, which is an inaccessible point and has good water nearby. There I will put an official, as commandant of the lands, with a detachment of 20 soldiers and 50 inhabitants, who will be at the same time colonizers and guards. ${ }^{41}$ 
It is surprising that Governor Maia seized and occupied only the hamlets around Vaviquinia, which lies halfway up the northern slope of the mountain, and did not press on to the summit, where the Doutels, who were clearly the primary instigators of the uprising, lived. Perhaps Governor Maia knew that his troops could not be relied on for more than the short time they had already been in the field. It is also strange that Governor Maia tells his readers in Lisbon very little about the ruler or other leading figures in Maubara; nor does he say much about the identities of the rebels. Maubute, nephew of D. Repreto, is the only rebel leader who is named. And despite the governor's claim that the murderer who had started the whole affair and led the rebellion had been killed, Maubute and the other members of the Doutel family had escaped. Greater insults to Portuguese authority lay just ahead.

\section{The Assassination of Governor Maia}

To further cement his authority over the rebellious kingdom, in early I887 Governor Maia summoned D. José Nocolau and the nobles of Maubara to Dili to sign new terms of vassalage, swear loyalty to the Portuguese Crown, pledge to obey the orders of the governor, and promise to pay the annual tribute. The third of March was set as the date for the ceremony. In the days before this, D. José Nocolau and his retinue, a number of other nobles, and the second-line troops from Maubara made their way to Dili. D. José Nocolau and his wife, Amelia Pereira, stayed with the guard of the Kingdom of Motael. Coincidentally, Lucas Martins, the newly appointed régulo of Motael, ${ }^{42}$ was placed in charge of the second-line Timorese troops (moradores) who, together with the small regular Portuguese colonial military, were to receive the vassalage of the régulo of Maubara.

Several days beforehand, however, Martins had complained to Governor Maia that members of the governor's staff had mistreated Martins's men. Two of the moradores had been thrown in prison for two weeks, Martins had been assaulted by the governor's secretary, Second Lieutenant Francisco Ferreira, ${ }^{43}$ and Martins's men had been forced to carry the governor on some sort of palanquin and were whipped if they did not run fast enough. The governor brushed aside the complaints, saying he would respond to these issues the following day. After this exchange, as he later 
testified, Martins "ordered all the officers under my command to reunite in my house at around 3:30 in the afternoon to decide that on the 3rd we would go to the Palace of Lahane to ask for justice from the Governor." ${ }^{44}$

On the second, Martins received a summons from Governor Maia. Just as he was leaving his house around noon, however, he found the colonel of the moradores at his door. The colonel told Martins that he was on his way to the governor's mansion in Lahane to complain about the secretary and other officials who had beaten several of his men. Martins agreed to accompany him and the two men set off together to Lahane. After a discussion with Governor Maia about wood needed for a bridge, the colonel prostrated himself and explained the abuse. After offering a stiff drink to calm his visitors and show his good intentions, the governor asked if they had prepared the one hundred soldiers for the ceremony the next day at which the régulo of Maubara was to sign the new terms of vassalage. After assuring the governor that the soldiers would be ready, the two men left Lahane and walked home. Later that day, Martins set out to visit D. José Nocolau, but passing the home of the colonel of the moradores he stopped and was drawn into a conversation the colonel was having with his men about the abuses committed by Portuguese officials and their intention to take revenge on the governor's secretary, Second Lieutenant Francisco Ferreira. After further discussion, the men decided that the next morning Martins and the coronel would again go to Lahane to ask the governor what he intended to do about their respective grievances.

As planned, on the morning of 3 March, Martins and the coronel went to Lahane, where they were surprised to find a rabble of angry men milling outside the governor's mansion, apparently intent on avenging themselves on the governor's secretary. Martins and the colonel entered the residence. Repeating his question of the previous day, Governor Maia asked if the one hundred men for the vassalage ceremony were ready. The two visitors said the troops were ready, and then pressed their case against the secretary. Irritated, the governor gave them a dressing down and then disappeared into his room and did not come out again. Frustrated, Martins and the colonel returned home to make preparations for the vassalage ceremony. Shortly thereafter, however, Martins was informed that the people milling around outside the governor's residence had beaten Second Lieutenant Francisco Ferreira. Fifteen minutes later Bishop D. João Gomes 
Ferreira arrived at Martins's home and asked what was going on. Martins explained that people had taken revenge against the governor's secretary. The bishop then informed him, "I saw Governor Maia dead in the road in Lahane." Governor Maia had been assassinated. ${ }^{45}$

Portuguese officials were uncertain what had happened. It appeared that in the course of exacting revenge on the secretary the moradores had gone a step further and killed the governor as well. D. José Nocolau of Maubara was staying with the commander of the moradores and his men were housed with the troops, so they too may have been involved. ${ }^{46}$ A long investigation ensued and a formal statement was taken from the ruler of Motael, Lucas Martins, who was eventually put on trial in Macau for the murder.

Remarkably, despite the assassination and the general state of confusion in the capital, two days later Portuguese officials in Dili carried out the state ceremony in which the régulo of Maubara renewed his terms of vassalage. ${ }^{47}$ D. José Nocolau was still recognized as the ruling king. But virtually all nineteen signatories to the I88I terms of vassalage were gone: only D. José Nocolau and D. Antonio Doutel remained. The signatories on the document from Maubara were listed with the titles indicated in table I. This list shows a major shift in power relations in Maubara. Whereas in I88I authority was divided between D. José Nocolau (as Brigadeiro Rei) from Guguleur and D. Gaspar da Costa (as Coronel Regente) from Vatuvou, in I887 Vatuvou had lost all representation. The Doutels' basis of support had also been greatly reduced, with only one of the three settlements that had contributed representatives to the first stranger kings from Suai Loro still represented (Lissadilla). The three autochthonous lineages that had received the stranger kings and had been assigned some sort of judicial function-Ikolau, Kaisave, and Raelete-were now on the ascendancy. The most important of the individuals from these hamlets was José Rodrigues da Silva, who in I877 was a sergeant, and who now appeared as the "major of Maubara"-the commander of the indigenous forces under the Portuguese military detachment.

Known by the Tokodede name Mauvili and only later in life baptized José Rodriques da Silva, he was in fact a distant relative of the Doutels. His great grandfather is said to have been a man named Opu Leki from Lio Telo (the collective name the area of Ikolau, Kaisave, and Raelete) who had had an illicit affair with the daughter of one of the Doutel rulers, resulting 


\section{TABLE 1}

\section{Signatories to Maubara's 1887 Terms of Vassalage}

Signatory, title, and hamlet

Village (current)

D. José (vulgar name Nocolau)

José Rodrigues da Silva, major of Maubara

Mau-Cau, lieutenant colonel of Dexidilla

D. Domingos, lieutenant colonel of Maubara

Manuclara, mestre campo

Clau, principal of Caicassa

Lacana, dato of Raelete

Manu-mana, dato of Hyculau (Ikolau)

Mau-Clau, dato of Caiçalu (Kaisave?)

D. Antonio Doutel, principal

Maleque, dato of Rainaba

Laco-Mone, dato of Raihahy
Guguleur

Maubaralissa

Lissadilla

$?$

?

Hamlet in Guguleur

Hamlet in Maubaralissa

Hamlet in Maubaralissa

Hamlet in Maubaralissa?

Guguleur

Hamlet in Guguleur

?

in pregnancy. ${ }^{48}$ The baby, named Laku Roma, was raised by the Doutels in Guguleur, but when he came of age was sent back to his father's family to become head of Lio Telo. ${ }^{49}$ Although it is impossible to date this exactly, the number of known generations in each lineage suggests that the young woman in question may have been the daughter of D. José Xavier Doutel, who ruled Maubara in the I750s. This is exactly the time that Maubara formally came under VOC tutelage, suggesting that the story about an illicit affair may be an allegory for a larger shift in alliances. Furthermore, there are quite specific accounts of Opu Leki's brother, named Barnado, who it is said "received" the incoming foreigners and "appointed" the governor by tapping on a book three times. ${ }^{50}$ Nearly a century after these events, Opu Leki’s descendant Mauvili, aka José Rodriques da Silva, had become an officer in the Portuguese second-line military.

This was the first step in the rise of a new lineage that would challenge for indigenous power in Maubara, and it was during this time that Mauvili 
established his own "palace" (called Lissalara, the same name as that of the Doutel's less than three kilometers away) and the name of his home area, Leo Telo, was changed to Maubaralissa. ${ }^{51}$ Was Mauvili simply an ambitious young man intent on demonstrating his worth and making a name for himself? Or was he also motivated by the oral tradition about his ancestor's failed relationship with the daughter of a Doutel ruler and the resulting humiliation at the hands of the ruling family in Guguleur? Alternatively, did he draw on the story of the Loro Liurai from Suai to lay claim to being descended from the original people of Maubara who, having been tricked by the clever nobles from the south, ceded claims to legitimacy and political power to stranger kings but were granted some sort of representative or even judicial function? That we cannot provide definitive answers does not make the questions any less worthy of being posed.

\section{Conclusion}

Portuguese efforts to co-opt traditional elites in Maubara were, in the end, unsuccessful because the rather grandiose Iberian notions of kingdoms (reino) and absolute rulers (régulo) ran aground on the hard reality that the geographic scope of social power of the indigenous rulers was highly circumscribed and rival claimants to traditional authority lived within walking distance of one another. Colonial recognition of Dom Carlos and later his son Gaspar da Costa in Vatuvou exacerbated tensions with the Doutels in Guguleur, resulting not in centralization but fragmentation and further conflict. The coronation of Queen Maria in I877 may have been motivated by the hope that a weak ruler would placate the Doutels without posing a threat to Vatuvou. But in the presence of weak dynastic authority, violence persisted. The Portuguese authorities then introduced an arrangement involving both a "king" and a "regent," but this too failed to bring order to the mountain. In retrospect, it is easy to see that the real problem stemmed from the mistaken Portuguese view that the long-standing practice of indirect rule offered a solution, when in fact this was a major source of the conflict and ongoing violence.

Like colonial officials before him and many who would follow, Governor Maia's response to political impotence in local affairs was the use of overwhelming force, the results of which, he bragged, "would be magnificent." 
What this meant was burning settlements, scattering the population into the forests, and then retreating before his own feeble force became more of a liability than an asset. The stated aim of this fury was the elimination of "criminal" elements in the population, but the real prize was land, seized as Crown property. Despite his military superiority, Governor Maia had persisted in employing vassalage, not direct rule, as the fundamental political strategy, and it was in the context of the vassalage ceremony to be held in Dili that grievances and opportunity converged and Governor Maia met his own end in broad day light in the street in his own capital.

What impact did the years of disorder and futile political maneuvering have on the people of Maubara? The hostility of Maubara's elites to the Portuguese, expressed so forcefully in the mid-eighteenth century and again during the territorial transfer of I859, only intensified and the local rivalry between Guguleur and Vatuvou became even more acrimonious. It appears, too, that the military solution of I886 had at least one unintended consequence: the Portuguese administration became reliant on local collaborators who were granted military ranks and command over the second-line colonial troops, thereby introducing a new rival for local power. Oral accounts of this period are so faint-really no more than a few names and what may be allegorical stories about disputed parentage and ownership of Chinese porcelain-that it is impossible to comment on what Portuguese methods and the rise of officers in the second-line military meant to the people of Maubara at the time. And yet two older informants do recall an episode that appears to date from precisely this time. The Doutel's house in Guguleur, called King of All, Brave King, constructed a new ritual house, and when the structure was completed an inaugural ceremony and celebration were held. The young Major Mauvili arrived but was not allowed to attend the ceremony because he had not contributed to the building. Spurned by the Doutels, he returned home and mobilized his own relatives to construct a new sacred house only a few miles away in Maubaralissa..$^{52}$ Such competitive house building may have taken place, but as is the case with the story of the stolen Chinese ceramics and the illicit romance a century before, this account is likely an allegory for the larger conflict pitting precedence of the King of All, Brave King lineage against the military rank of an upstart and the pro-Dutch politics of the Doutels against the collaborationist Mauvili. 


\section{4}

\section{The Uprising and Devastation of 1893}

$\mathrm{T}_{\mathrm{h}}$ conventional wisdom in East Timor is that the people in the eastern districts, collectively referred to as firaku, are taciturn and temperamental, historically refused to obey the Portuguese and waged repeated rebellions, while the people in the western districts, referred to as kaladi, are docile and obedient, succumbed to colonial domination and meekly provided labor to fuel the coffee economy. ${ }^{1}$ This makes for a good story but very poor history. For during the eighteenth century, when the Portuguese strongholds were almost exclusively in the western and central regions-Lifau, Batugade, Dili, and Manatuto being the most important-rebellion by both the mixed community of Topasses that developed around the early Portuguese settlements of Larantuca and Lifau and indigenous polities was most common in the western regions. This geographic distribution was a simple function of the limited reach of the early governors, not a reflection of culture or character traits. During the second half of the nineteenth century rebellion was again far more frequent in the west than in the east, and perhaps no kingdom resisted the Portuguese colonial administration more than Maubara. ${ }^{2}$ Even after the minor affair in Vatuboro in I86I, the standoff in Vatuvou in I867, the war with Liquica in I870-I872, and the treachery of I886, the people of Maubara made one last attempt to expel the Portuguese from the kingdom. At least that is how the events of I893 are typically described in colonial documents and have been treated by historians of colonial Timor. 
This chapter examines the last of the nineteenth-century "rebellions" in Maubara. It shows that while there was a plot to free the kingdom from Portuguese rule, the actions taken by the conspirators in Maubara were less threatening than Portuguese officials believed them to be. Despite complex efforts to draw on a variety of alliances, the means available to the protagonists were limited and the insurrection was largely symbolic: an appeal for help from the Dutch outpost in Atapupu, the activation of alliances with neighboring kingdoms, an attack on two Portuguese customs posts, and the raising of an old Dutch flag. The conspirators lacked the capacity to mobilize large numbers of men or engage the Portuguese colonial regime in sustained warfare. The Portuguese response was not to arrest or otherwise target the individual leaders and those who actively participated in the hostilities; instead, Governor Forjaz and his military officers viewed the entire kingdom as traitorous and waged a campaign to punish the population, to humiliate local elites, and to demonstrate European technological, cultural, and moral superiority. But Portuguese military capacity was far weaker than most colonial officials or Portuguese historians have cared to admit, and it is this weakness that explains the indiscriminate use of force.

\section{Pretenders and Intrigue}

In the years immediately following the 1886 uprising, the Portuguese regime in Dili implemented a variety of measures to exert full control over Maubara. The customs posts in the town of Maubara and the coastal hamlets of Daire and Vatuboro were strengthened and new restrictions were placed on travel between kingdoms in order to prevent overland smuggling through the mountains to the Dutch border. The Portuguese administration also increased aid in material and personnel provided to the military command in the Kingdom of Maubara. ${ }^{3}$ Colonial troops from Goa and Portugal's African colonies were posted in Maubara, though the numbers were probably never more than a dozen or two at any one time. Finally, the colonial administration continued to discuss ways to promote and reap the profits from coffee cultivation. The first land grants were made in the I88os to Portuguese military officers interested in developing private coffee plantations. ${ }^{4}$ Nevertheless, the ability of the colonial state 
to dictate production remained limited and even the lands in Vaviquinia that had been seized as indemnity after the 1886 uprising and declared Crown property soon fell back under use by local cultivators. The initiative behind coffee cultivation in Maubara lay with indigenous smallholders.

Taken together, Portuguese policies subordinated the position of régulo and greatly increased the authority of the Portuguese military commander, and with this the role of his ambitious underling, Major Mauvili, who adopted the Portuguese name José Rodrigues da Silva. But the administration's reach was short, limited to the coastal town of Maubara and the customs posts. Beyond that there was still a great deal of lawlessness. In I887 the colonial gazette included a news item about four murders committed in Maubara, and the following year ran a report that additional troops had been posted in the kingdom in order to prevent the escalation of minor disturbances. ${ }^{5}$ Furthermore, manipulation of traditional authority exacerbated fractures among local elites. D. José Nocolau was formally recognized as régulo of the kingdom, but his authority probably extended no further than the hamlets in a two- or three-kilometer radius from Lissalara and the mountain peak. Maubute, who had evaded punishment after the events of I886, was outraged by the capitulation of his relatives and other noble families to the Portuguese. Sometime after this he left the family home in Lissalara and took up residence in the hamlet of Caicasa, one hour's walk down the northern slope of the mountain and outside the primary coffee-producing belt.

A combination of events in 1893 exacerbated the already tense situation in Maubara. Early that year the Netherlands and Portugal agreed to survey the mutual border on Timor, and in June they signed a new binding agreement on boundaries, commerce, and navigation. ${ }^{6}$ News of this must have reached the leading families in Maubara, for whom a more precise demarcation of the border would hamper contraband trade. At about the same time Governor Forjaz, who had arrived in the colony in February I89I, breathed new life into the idea of constructing a military post high up on the north side of the mountain. Architectural plans and a budget were drafted for a military command post to be constructed on a ridge in Lauvei, from which there were spectacular views. ${ }^{7}$ This location was a short walk from the Doutel compound in Lissalara and overlooked Maubute's new base in Caicasa. Any surveying conducted by Portuguese officials 
would have come to the immediate attention of the inhabitants spread across the upper reaches of the mountain.

The third event was a death: sometime in late I890 or early i89I régulo Dom José Nocolau of the Doutel family died. ${ }^{8}$ As a result, Governor Forjaz explained in a subsequent report, "the kingdom was in disorder, for there were many pretenders to the succession, all judging themselves with the right to govern, which brought me to order the election for the Ruler and Colonel to proceed." Given the competing interests and claimants, it must have taken some time for all parties to reach an agreement. A new terms of vassalage cannot be found in the archival record, but from subsequent documents it appears that the aged and now widowed Dona Maria Doutel, who had been recognized as the queen in the late I870s, was once again selected as the ruling queen (rainha) of Maubara. ${ }^{10}$ Although Portuguese documents do not explain the reasons for this choice, she may have been appointed because of seniority or perhaps to keep the position of régulo out of the hands of D. José Nocolau's recalcitrant sons.

Portuguese hopes that the "election" of Dona Maria would restore order and tranquility to Maubara were misplaced. Not only were there "many pretenders to the succession," as Governor Forjaz wrote, but the regime's own Major Mauvili was engaged in his own machinations. The major, it seems, had set his sights on translating military rank into kingship. In a long document produced in I893, Governor Forjaz wrote,

As the Coronel Queen D. Maria was already quite elderly and single, the intrigue between the pretenders began again in secret. One of these individuals, certainly the most intelligent, and who had given most proof of his fidelity to the government, was Major Maubili. He married the widow of D. José [Nocolau], which caused displeasure among the other pretenders, and even more incited them to intrigue, in which took part some Chinamen merchants who were discontent with the commander, for he, through his great vigilance and incorruptibility, had not permitted them the customary contraband. ${ }^{11}$

The marriage to D. José's widow, D. Amelia Pereira, cannot be confirmed from oral sources but may in fact be true, for in a subsequent report the governor noted that Dona Amelia died soon after marrying Mauvili. It 

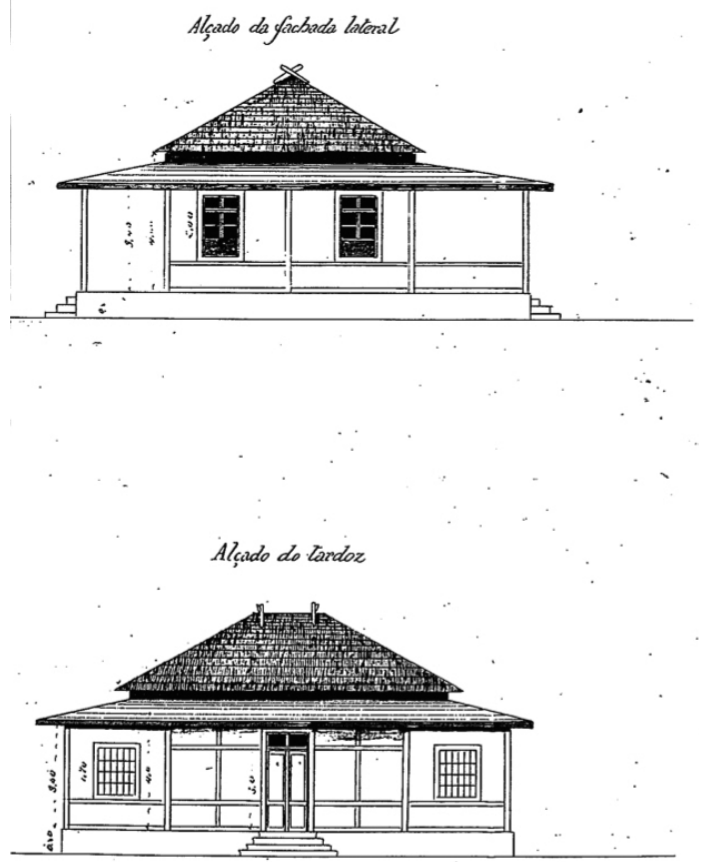

FIGURE 6 Architectural plan of the Portuguese military post to be constructed in Guguleur

then was rumored that the conniving Major Mauvili planned to marry the elderly former queen, Dona Maria Doutel, presumably as a way to further cement his claims to power and legitimacy in the eyes of the Portuguese administration. Indigenous power was still understood in terms of proximity to precedence and, if possible, ownership of the various objects-canes of office, symbols of rank, and so forth-that symbolized that precedence.

\section{Raising the Dutch Flag}

Pretenders to the throne, inscrutable Hakka merchants, and understaffed Portuguese military officers made for a volatile situation. It was in this context that a series of relatively minor incidents activated a complex set of alliances and the formulation of a plot in mid-I893. ${ }^{12}$ Earlier that year, a Portuguese lieutenant who was ill had traveled by boat from the garrison at Batugade to Maubara. The dugout canoe in which he made the last leg of the journey was damaged en route, so upon arrival in Maubara the 
military commander in the old Dutch-built fort in Maubara, Lt. Joaquim dos Santos, ordered a man named Moncura, who was married to one of Queen Maria's nieces, to see to it that repairs were made. At about the same time Lt. Santos also asked Queen Maria to order villagers to prepare lime needed for the repair of a bridge on the main street in the town, and she duly forwarded the order on to the chief of Caicasa. The grandson of the queen's brother, Maubute, who was living in Caicasa, objected. He insisted that the people must first build a house for him before they could perform unpaid work for the hated Portuguese authorities on the coast. This led to a heated dispute between the chief of Caicasa and Maubute. Maubute was so angry, according to Governor Forjaz's account, that he went "to the extreme of tearing out his beard, which among the Timorese is the greatest insult." 13

Facing a challenge to his authority, the chief of Caicasa appealed to Queen Maria and she summoned her brother's unruly grandson. But Maubute refused to see her. According to Portuguese documents, Queen Maria responded by sending a contingent of her troops to Caicasa to confront Maubute, though in all likelihood Lieutenant dos Santos was behind the order. The force approached Caicasa with a white flag raised to indicate peaceful intentions. The commander of the contingent tried to convince Maubute to come to the Portuguese fort in the town, where "justice would be done to him." According to the reports received by Governor Forjaz, Maubute asked for two days' time before coming to town, but the commander insisted that he must come right away. Suspicious of the commander and unwilling to face the Portuguese officials at the presidio, Maubute fired his weapons. The queen's men rushed into the hamlet in pursuit but were unable to capture Maubute, who fled to the heavily forested south side of the mountain (in present-day Guico). Oral accounts of the encounter provided by informants in Maubara differ in a number of details, but concur that there was a standoff and that Maubute fled. ${ }^{14}$ After the confrontation in Caicasa, it is said, Maubute and his two closest lieutenants, Asuwain (warrior) Matias and Buru Bara, ${ }^{15}$ retreated to a hideout on a high ridge where Maubute kept a stash of palm liquor. ${ }^{16}$ Scouts working for the Portuguese military commander discovered their location, surrounded the three men and ordered them to surrender. The Portuguese commander advanced to shake hands but Maubute, not accustomed to 
this western formality, struck him. The commander's men opened fire. Matias was killed instantly but Buru Bara and Maubute, it is said, proved invulnerable to the bullets and escaped into the forests of Guico.

When word of the disturbance reached Dili, Governor Forjaz instructed all available first-line troops and fifty second-line moradores to march to Maubara. The Portuguese commanders and a number of indigenous figures met at the presidio to discuss the situation and decided to proceed with the capture of Maubute. The decision was communicated to Queen Maria Doutel and the principals, who readied their own troops. The combined force set out but turned around when they encountered a dead goat in their path. ${ }^{17}$ The Portuguese commanders held further meetings with the second-line military officers and nobles who requested two months to capture "the unruly man." After receiving approval from Governor Forjaz in Dili, on 6 April 1893, Captain Pedro Dionysio Barreiros and the other Portuguese officers convened a meeting at which Queen Dona Maria Doutel and ten other leading figures in Maubara signed a "treaty" attesting to the disobedience of Maubute and the chiefs of Daire and Vatuboro and apparently swearing obedience and promising to assist the Portuguese authorities so that "their villages will not be sieged and conquered." Although not stated on the "treaty," elsewhere Governor Forjaz reveals that the representatives of the Kingdom of Maubara also agreed to pay two thousand Dutch florins to the government as compensation. ${ }^{18}$ Again, it is worth considering the signatories listed in the treaty (see table 2). No longer are the indigenous notables who participated in the selection of the ruler and signed the document divided evenly between the Doutel family in Guguleur and Mauvili's rising faction in Maubaralissa. It now appears that the Governor Forjaz and his officers were concerned with geographic "representation." The list includes one signatory from each of the leading families in Guguleur, Vatuvou, and Maubaralissa, and one from each of the lesser subsidiary hamlets of Lissadilla, Vatuboro, and Daire that long-ago had been selected to assist the original ruler of Maubara. ${ }^{19}$ The only locality missing on this list is Vaviquinia. It may be that Vaviquinia did not have a prominent noble (dato) family or that the area had not yet been recognized as a political entity, though it seems even more likely that the exclusion was punishment for the events of 1886 when the best lands in the area had been declared Crown property. 
TABLE 2

\section{Signatories to Maubara's Treaty of Obedience, April 1893}

Signatory and position

D. Maria D'ontel (Doutel)

Sá Divesse, ${ }^{\mathrm{a}}$ as representative of D.

Gaspar

José Rodrigues da Silva, common name

Maubili

Sereloy, common name the Black King ${ }^{b}$

Maucabai, lieutenant colonel of

Fato-boro

Bessidau, lieutenant colonel of Daire

Baucau (Mau Cau?), lieutenant colonel

of Decidilla

Atibau, lieutenant colonel

Yang Ha-hing, captain of the Chinese community

Yang Hinchong, first class merchant

Lay Athang, first class merchant
Village (current)

Lissalara, Guguleur

Vatuvou

Maubaralissa

Lissalara, Guguleur

Vatuboro

Daire

Lissadilla?

?

Maubara Villa?

Maubara Villa?

Maubara Villa?

a This is almost certainly Sada Bessi, son of D. Carlo and cousin of D. Gaspar.

${ }^{\mathrm{b}} \mathrm{He}$ is most commonly remembered in Maubara as "Dom Repreto."

With the treaty concluded, Lt. Joaquim Augusto dos Santos traveled to Dili to report directly to Governor Forjaz. Governor Forjaz questioned Lt. Santos about the causes of the disturbance and the lieutenant admitted that sometime before the orders for boat repairs and lime production Major Mauvili had informed him that Maubute, his uncle Repreto (better known to the Portuguese as the Black King) ${ }^{20}$ and other nobles intended to "ask for a Dutch flag from Atapupu." ${ }^{21}$ The meaning was clear: they intended to declare their allegiance to the Dutch and rebel against Portuguese rule. At the time Lt. Santos had dismissed the report.

In fact, not long after Lt. Santos left for Dili, Maubute, Repreto, and their allies seized on the opportunity to put their plan into motion. The first step was to send two men "to the house of the Coronel Regent, whom 
they intoxicated" so that they could steal the kingdom's copy of the LusoDutch treaty of I859 that had ceded Maubara to Portugal. ${ }^{22}$ Three envoys bearing the document and "coffee and cigars" as gifts then traveled by boat to the Dutch port of Atapupu, thirty-five miles to the west, to offer their kingdom as an ally to the Dutch in return for military assistance with which to launch an uprising against the Portuguese. ${ }^{23}$ Other envoys bearing gifts were dispatched to the kingdoms of Mahubo and Cailaco, located to the south and southwest, respectively, to entice their rulers to join the uprising. ${ }^{24}$ A second meeting, attended by a number of Hakka merchants, was held in the coastal hamlet of Daire, at which the conspirators agreed that when news of Dutch support arrived from Atapupu they would begin the uprising. ${ }^{25}$

Before dawn on 26 May, the conspirators staged a surprise attack on the Portuguese custom posts in Daire and Vatuboro. Each post was manned by a European corporal and a few African or Marathan soldiers. Governor Forjaz's written accounts of the attack vary considerably. His earliest letter about the incident simply states that one corporal and two privates had been injured. In a subsequent report, however, he explained that the valiant but out-manned soldiers had held their positions "until sundown, upon which, their munitions exhausted, they were beheaded" by the attackers. ${ }^{26}$ What is clear is that after carrying out the attacks the raiding parties immediately retreated back up the mountain to their settlements and raised a Dutch flag. ${ }^{27}$

Having received information about the confrontation in Caicasa from Major Mauvili's messenger, having been briefed about the background to the intrigues by Lt. Santos, and having confirmation of the visit of nobles from Maubara to the Chinese and Dutch in Atapupu from the captain of a steamship that arrived in Dili the same day, Governor Forjaz immediately penned a letter to the Ministry of Overseas Affairs in Lisbon to explain the outbreak of rebellion. He wrote, "Three principals from Maubara have gone to Atapupu to offer the Dutch their allegiance. I have grave suspicions that all this is promoted by the Captain of the Chinese in Maubara. . . . The causes lie in the rumor that Timor is to be sold to the Dutch. The Dutch ports are free trade which would be of great convenience to the Chinese." ${ }^{28}$ In a long report written later that year, Governor Forjaz explained that based on information obtained from prisoners, the causes of the revolt 
were resentment over forced labor duties imposed by the military commander (including the cutting of wood and production of lime) and "the hatred of Maubuti and some other chiefs for everything that was Portuguese." 29 "I must add," Governor Forjaz wrote, "this Maubuti was an intelligent and evil man, but of great influence and importance in the kingdom [of Maubara], for his specialty as rei de pomali [lit. king of sacred ritual] and the great riches that he possessed in muti-sala [a type of yellow coral beads] and moons of gold." ${ }^{30}$

This description of Maubute is intriguing. The "treaty" signed a month before the uprising refers to Maubute as the "chief of Caicasa," which is odd given the governor's later description of the dispute between Maubute and an unnamed chief of Caicasa over the production of lime. But here Governor Forjaz calls Maubute a "king of sacred ritual." Given that Maubute had moved away from his family, it is extremely unlikely that he was in fact the formally recognized ritual leader of the No Liku No Besi house and guardian of the lineage's sacred items or lore. ${ }^{31}$ It is possible that the governor's description is simply incorrect. It is equally possible that after the attack the governor described Maubute as a "king of sacred ritual" as a way of dismissing his importance, as if to say that Maubute was not the head of a territorial unit or of human subjects. But perhaps something else altogether explains Maubute's new status. This is the only document from the eighteenth or nineteenth centuries that identifies a ritual specialist in Maubara. Maubute's position in I893 as rei de pomali suggests a revealing transformation: on the I88I terms of vassalage, Maubute was listed as a dato (prince or noble); he was omitted from the I887 terms of vassalage, quite obviously because he had "betrayed" the Portuguese the year before; and then in 1893 he appears in a wholly new capacity associated with "ritual" authority, not the "political" sphere. Although it cannot be proven, this suggests that one response to the loss of social status and rank within a ruling house was to fall back on the "ritual" sphere. He may therefore have declared himself rei de pomali to appeal to indigenous conceptions of power and as a means of countering the co-optation of his relatives and other local elites. ${ }^{32}$

Whatever his self-proclaimed status within local society, it is clear from the Portuguese accounts that Maubute's conspiracy involved four distinct levels of alliance. First, Maubute, his uncle Repreto, and perhaps 
other members of the Doutel family who had lost out in the struggle for succession were allied with nobles from Vatuboro, Daire, and other hamlets in the Loes River valley to the south. Second, these indigenous nobles were working closely with some of the prominent Hakka merchants determined to maintain the duty-free trade from which they and the populace benefited. Third, Maubute and his accomplices sought to activate longstanding ties with ruling families from Mahubo, which had been part of the VOC treaty of I759, and Cailaco. ${ }^{33}$ Fourth, appealing to the terms of the stolen I859 treaty and Dutch promises at the time of the territorial transfer that the people of Maubara would not be mistreated, they sought the backing of the Dutch commander in Atapupu.

And there was more. Citing a report produced by the commander of the naval station in Macau, in November I893 Governor Forjaz cryptically wrote that "the principal causes of the revolt of the régulos of Daire and Vatuboro were attributed to the influence and criminal instigation of an individual whose name was not yet denounced." Governor Forjaz stressed the need for a full investigation of this "unrevealed instigator." ${ }_{4}$ There is no mention of this mysterious "instigator" in the official report Forjaz wrote a month later about the rebellion. However, on the page of the governor's report detailing the immediate causes of the rebellion, there is a handwritten note in the margin stating, "For the ministry of the Kingdom [word illegible], it falls upon us to recommend that Your Excellence serve to dispatch the convenient orders so that on this individual be exercised the greatest vigilance to the end of preventing his return to Guiné.”35 It appears, therefore, that an individual from the Portuguese colony of Guinea, most probably an African soldier in the colonial army, had deserted his post and "gone native," and in I893 had played a prominent role in the conspiracy. ${ }^{36}$

The uprising in Maubara was simultaneously far less and significantly more than Governor Forjaz's depiction implied. On the one hand, the governor seemed intent on portraying the treachery as a full-flown rebellion. He later wrote, "It is certain that the conspirators next decided to massacre the detachments and to attack the fort, and to call all the villages to arms, telling them that the Dutch government had accepted them, and that auxiliary forces were on their way and by sea a steam-powered gunship with even better arms." ${ }^{37}$ But the description of events reveals that this was a 
simple attack on two customs posts, not a rebellion involving the mobilization of a large war party or generalized insurrection. On the other hand, official correspondence seemed to downplay the scope of the violence, simply reporting that "part of the kingdom of Maubara has revolted." ${ }^{38}$ Yet this was not a local but rather a pan-national event, involving a notorious Timorese rebel (Maubute) and allied nobles, a number of "Chinese" merchants, and an "African" soldier, who together appealed for Dutch support to free the kingdom from Portuguese colonial rule and have it recognized as part of the Netherlands Indies.

\section{Maubute's Head}

Governor Forjaz was determined to quash the rebellion but he faced significant obstacles. The Portuguese steamship Dilly was in Hong Kong for repairs at the time, so Forjaz sent a telegraph message to Macau requesting "a boat equipped with canons or a small service boat." He noted that while he had sufficient forces to suppress the rebellion, "I am not permitted to proceed with the rapidity necessary in these cases." ${ }^{39}$ This is apparently a reference to requirements that colonial officials receive permission from Lisbon before undertaking military operations against the indigenous population in the colonies. Furthermore, Forjaz was concerned about the possibility that military operations would disrupt harvest of the year's excellent coffee crop.

With these considerations in mind, the governor's first move was to mobilize troops from loyal kingdoms. "I ordered the gathering of troops from Liquica and Manatuto, and also for all the available firstline troops and inhabitants to depart immediately" for Maubara on the Dutch steamship then in port. ${ }^{40}$ Governor Forjaz and one hundred more soldiers embarked on smaller boats that afternoon. On 3I May, an expeditionary force made up of first-line government troops and larger numbers of second-line warriors from the kingdoms of Pisso, Ulmera, and Fatumasse, under the command of the Timorese officer Albino Antonio Ribeiro, arrived in the town of Maubara. "With the garrison of Maubara reinforced in this manner," Forjaz later wrote, "I awaited news that would enable me to judge the intensity and gravity of the uprising." ${ }^{41} \mathrm{~A}$ second column of troops from the eastern kingdoms, which the governor 
deemed to be "more loyal and more accustomed to fighting by our side," soon arrived. A third column from the Dili-based Company of Sica, under the command of Francisco Martins, was deployed to raise troops in Atsabe, Deribate, and Ermera in order to prevent the Kingdom of Cailaco from aiding the rebels in Maubara.

The governor's strategy was to deploy the two columns in a pincer movement, with the troops already in Maubara town ascending the northern slopes of the mountain and the troops from the east, which had massed in the Loes River valley, moving up the southern slopes. The columns were to meet at the mountain ridge in the vicinity of Major Mauvili's home in Maubaralissa. The aim, in the governor's words, was "to isolate the kingdom of Maubara and its allies" and "to put the rebels between two fronts." ${ }^{2}$

Military operations against Maubara lasted for three weeks. The governor's own account of the brutality is straightforward: indigenous settlements were either "conquered" (escalladas), "destroyed" (destoe), or "burned" (incendeia). The daily tally was both impressive and terrifying. On 6 June the forces "burned" four hamlets; on the gth the hamlet of Morae was "burned"; on the Ioth four hamlets in Vatuvou were "seized and conquered" and another seven hamlets in the Loes River valley were "burned"; on the I2th and I3th twenty villages were "seized and conquered"; on the I4th the columns reached Maubaralissa; on the I6th all hamlets in Guguleur were "attacked"; on the I8th and Igth various hamlets in Vaviquinia were "seized" or "burned"; on the 22nd sixteen hamlets in Vatuboro were "burned"; on the 23rd various hamlets in Decidilla were "seized." The Portuguese warship Diu finally arrived in Dili on 24 June. Massive destruction had already been inflicted on Maubara, but that did not prevent Governor Forjaz from taking advantage of the even greater technology superiority now at his disposal. ${ }^{43}$ After disembarking a number of troops to reinforce the capital, the Diu sailed to Maubara town to communicate with the local commander about the course of operations, and then continued westward past the cliffs of point Carimbala to Vatuboro, at the mouth of the Loes River, where it commenced bombardment of the indigenous settlements. That day fifteen hamlets in Caicassa-Vou were "burned"; on the 25th another twelve hamlets in Vatuboro were "burned"; and on the 27th the remaining hamlets in Daire and Vatuboro were "conquered." Finally, on 
28 July, Governor Forjaz declared operations against Maubara complete. ${ }^{44}$ From Maubara, the armed columns proceeded to Cailaco and the Diu continued to Cotubaba and Batugade in order "to prevent the flight of rebels and coffee" into Dutch territory.

The operations against Maubara had resulted in total destruction. A Macau newspaper ran a brief report celebrating the operation: "As for the Portuguese expedition to avenge the murder and mutiny in Maubara, there is the most exciting news. On the second attempt Babequenia [Vaviquinia] and Bubuleur [Guguleur] were taken, the black king [rei preto], who was the principal chief of the rebels, was arrested, and quite a few Chinese were taken prisoner." ${ }^{45}$ This cheery description grossly downplays the extent of the violence. The governor's own account reports that "99 heads were cut off" by the Timorese auxiliaries and more than three hundred people were killed. ${ }^{46}$ Several hundred people were taken prisoner as well. Of greater significance is what the governor's letters and official account reveal about the basic strategy employed. At least fifty-five hamlets had been burned and another twenty-eight conquered. Assuming an average hamlet size of eighty individuals and a total population in the kingdom of perhaps nine thousand, the homes of at least half of the entire population were razed to the ground, and those of another quarter of the population were "conquered" and probably lost property as well. The aim was not to round up and exterminate the population, as the German colonial military did to the Herero in South West Africa a decade later. ${ }^{47}$ Rather, Governor Forjaz sought to devastate hamlets and homes in order to demonstrate superiority and instill fear.

The devastation of the kingdom may have been deemed a "success," but Maubute remained unaccounted for. It was said that Maubute had been shot numerous times but that bullets could not kill him. After several false leads, his loyal lieutenant Buru Bara received word that Maubute had fled from the Portuguese offensive to the rocky crags of Fatubuikaren in Atabae, to the west of the Loes River. ${ }^{48}$ When Buru Bara reached the Loes River, however, a man told him that there was no need to go on because Maubute had already been killed. Indeed, Portuguese troops had surrounded Maubute at Fatubuikaren and he was again ordered to surrender. According to one oral account, Maubute told the commander, "I will not surrender. I will not go with you to Dili. I do not want the foreigners [malae] 
here because this land belongs to us, not the white people." The Portuguese commander then drew his sword and struck Maubute's neck, but the sword did not cut him. Maubute spoke again, "Rather than surrender, I will give you my sword." Wielding the rebel's own weapon, the Portuguese commander beheaded Maubute. The severed head was taken back to Dili, where it is said to have been stored in a large jar of formaldehyde in a government office building. ${ }^{49}$

Buru Bara eventually did locate Maubute's body and brought the headless corpse back to Maubara. An envoy was sent to ask the remaining members of the Doutel family if they wanted Maubute to be buried in the family compound in Lissalara, at the peak of the mountain. Having lost the family elders and much of their property, the relatives refused to accept the remains and told Buru Bara to bury Maubute's body elsewhere. So the corpse was taken a short distance down the southern side of the mountain to a place called Ulamenahu, where it was buried, and the location was then renamed Lakudole, meaning "forgive him for doing wrong." 50

The bombardment of Maubara from sea and the brutal military operations on the ground left hundreds of people and livestock dead. Left unburied because the population had dispersed into the forests, the rotting corpses caused a major cholera outbreak that quickly spread as far as the Dutch port of Atapupu, across the strait to the island of Alor, and west to Dili and beyond. Portuguese records from early I894 note that cholera had caused 279 deaths in Maubara, I62 deaths in Dilly, and 75 deaths in Manatuto. ${ }^{51}$ It appears that the ethnic Chinese community in the town of Maubara was particularly hard hit by the epidemic. In the small Chinese cemetery, located on a rocky hillside overlooking the river south of town, there is a stone tablet with the inscription: "Buried on an auspicious day in a winter month of the 29th year of the Guang-xu reign.” This would have been in the last months of 1903 or the early months of I9O4. The tablet lists the names of sixty individuals and another eleven "people of old" (i.e., ancestors), but does not specify the cause of their death or the reason for the memorial stone. It seems likely, though cannot be proven, that most of these were victims of the cholera epidemic, and that it was not until a decade after the devastating military campaign and epidemic that a Hakka merchant who owned the "Big Company," and hence was probably the captain of the Chinese community in Maubara, funded the erection of a commemorative burial stone in the cemetery. ${ }^{52}$ 
And what of the survivors? During the course of operations, the Portuguese military officer Porphyrio Zepherino de Souza captured the aged Queen Dona Maria, the Black King, and three other leading nobles. He sentenced Dona Maria and the men to death, ${ }^{53}$ but was overruled by Governor Forjaz, who instructed him to bring the prisoners to Dili to be tried in a military tribunal. The administration threatened to send the aged queen into exile in Mozambique, but there is no evidence that this was ever carried out. $^{54}$ The Doutels had suffered terrible defeat. So, too, had Dom Gaspar of Vatuvou, who the colonial gazette reported to have died a natural death soon after the rebellion. ${ }^{55}$ According to oral accounts, however, Mauvili had a hand in the fate of both families. Some sources claim that Mauvili murdered Dom Gaspar for "betraying" the Portuguese and exhumed the grave of Dom Cleto in order to steal symbols of authority that had been buried with the former régulo. ${ }^{56}$ And it was Mauvili, the Doutels' distant relative, now known as José Rodrigues da Silva, who on 7 November I893 was formally appointed as the new king and colonel (coronel rei) of the Kingdom of Maubara. ${ }^{57}$

\section{Conclusion}

The prelude to and plot of I893 reveals the shifting terrain of alliance, overlordship, and competing claims to authority in Maubara. The territorial exchange of I859 left leading members of the Doutel family feeling betrayed by the Dutch, hostile toward the Portuguese authorities in Dili, and outflanked by their distant relatives in Vatuvou. Ongoing conflict, however, resulted in a temporary reversal-symbolic recognition of the Doutels legitimacy-but also the compromise appointment of both a ruling king/queen from Guguleur and a regent from Vatuvou. The plot of I893 was masterminded by the former dato turned ritual specialist Maubute, a leading Hakka merchant and, it appears, an unidentified African soldier who had defected from the colonial military, who together had appealed to the Dutch to support their effort to free the kingdom from Portuguese rule. Their actions, however, were largely symbolic. They lacked the capacity to launch a full-scale assault or engage the Portuguese military forces in sustained combat. Hence, in the face of the vastly superior Portuguese military offensive, Maubute fled to the crags of Atabae, where he was eventually beheaded. 
The Portuguese response to the plot appears to be completely out of proportion to the actual threat. The first- and second-line Portuguese troops razed the homes and food stocks of villagers who knew nothing of the plot and had no involvement in the attacks on the customs posts. Massive and indiscriminate reprisals were the only thing the Portuguese governor and his officers could conceive of to address the insult to their standing and pride. And Maubara was not alone, for once Governor Forjaz had mobilized loyal indigenous troops and summoned a gunship, both Portuguese military commanders and their Timorese subordinates were keen to press their advantage, attacking neighboring kingdoms and leaving a vast trail of devastation, and ultimately disease. After the rebellion, indigenous authority passed to Mauvili, from the hamlet of Maubaralissa, whose own lineage can be traced back to an illicit affair with a Doutel daughter and the birth of an illegitimate son sometime in the mid-eighteenth century.

Today, people in Maubara remember Maubute's name but know virtually nothing of the devastation unleashed against their ancestors. Given the scale of the violence inflicted on the people of Maubara, it is once again puzzling that so few details of the uprising and the atrocities unleashed by the Portuguese survive in the oral tradition in Maubara. What is remembered is limited to the names of a few leaders, the places where they rose and fell, and the terrible epidemic that resulted from the Portuguese offensive. But suffering and defeat appear to be of secondary importance in oral accounts. The protagonists are remembered today in Lissalara and a few surrounding hamlets as links in a chain that connects origin stories to the present, Further afield, these figures are generally not acknowledged because they have no place in other houses' origin stories. What the Portuguese viewed as a general uprising has survived as the pride of particular families, not as part of a common experience of resistance or suffering. And yet, in 1945, 1975, and again in 1999 the views of the Doutels and many of the families living in the upper reaches of the mountain must have been shaped, consciously or otherwise, by stories of previous hostility to the Portuguese, the struggles during the last four decades of the nineteenth century, and long-standing rivalries between competing lineages. 


\section{5}

\section{High Colonialism and New Forms of Oppression, 1894-1974}

\footnotetext{
$\mathrm{T}_{\mathrm{h}}$ he onset of direct colonial rule in the I89os did not bring an end to the recurrence of violence in Maubara, it merely transformed the means at the disposal of the state and the purposes for which violence was employed. Military operations gradually gave way to the institutionalized seizure of land, tribute in kind was replaced by the imposition of an onerous annual head tax and forced labor, and local administration slowly passed from the hands of military officers to civilian officials and indigenous functionaries. This chapter traces the course of these changes in Maubara across the eighty-year period beginning with Governor Celestino da Silva's long tenure, through the proclamation of the Republic in I9Io and the Great Rebellion of I9II-I9I2, the heyday of the white plantation economy in the I920s and I930s, the brief but brutal Japanese occupation, and ending with the post-World War II reimposition of Portuguese colonial rule. In contrast to both imperial and nationalist narratives of colonial rule in twentieth century Timor constructed around colonial glory and nationalist resistance, this chapter focuses on the more mundane processes by which late colonial rule transformed local elites and marginalized the populace from the land.

Throughout the nineteenth century the leading families in Maubara had engaged in fierce rivalries over traditional authority and experienced recurrent bouts of mass violence, but the centrality of a paramount indigenous rulers of the kingdoms was never directly critiqued and no new conceptions of community or political organization emerged. But between I894
} 
and I9Io Portuguese colonial statecraft made a mockery of the notion of independent native states and popular acceptance of traditional authority declined greatly. During the following decades the colonial administration promoted a revival of indigenous rulers. For the Portuguese, the symbolism of monarchy and the willing collaboration of individual régulos could be harnessed to the regime's economic goals of taxation and the procurement of labor necessary to fuel the large-scale production of coffee.

Portuguese colonial policy and practice alienated the population from both land and labor and transformed people who once thought of themselves as members of particular houses and subjects of a kingdom into the amorphous and racialized category of "natives." In Maubara these changes in subjectivities were reinforced by sequential efforts made by missionaries to convert the population to Catholicism, halfhearted Portuguese initiatives to document and employ native "uses and customs," and legal assertions about citizenship that in fact served to restrict rights. In the face of this colonial onslaught, people in Maubara sought to maintain lineages, origin stories, and indigenous conceptions of rights. Whatever potential such ideas may have had, however, was severely curtailed by the limited opportunities for education, the complete absence of print media, and the isolation maintained by the colonial regime from the nationalist movements in the other Portuguese colonies.

\section{Monarchy Usurped and Transformed}

The arrival of Celestino da Silva in May I894 to take up the governorship of the colony marked the beginning of the most concerted effort yet to bring the entire territory and population under Portuguese control. A career cavalry officer and committed monarchist, Silva had no qualms about the use of force to subjugate the indigenous population and demonstrate "full and effective control," which since the I885 Treaty of Berlin had become the basis for international recognition of colonial claims. As Katharine Davidson observes, Silva arrived in Timor "intensely conscious of the campaigns being waged by Portugal against the African tribes [in Angola and Mozambique] during this decade and was determined to emulate such opportunities, as he saw it, for military glory, national face-saving and territorial aggrandizement." 1 
Soon after his arrival in Dili, and with the cholera epidemic that resulted from the military operation against Maubara still ravaging the north coast, Governor Silva took action to resolve Maubara's "disloyalty" once and for all. Three initiatives were of particular significance. First, Silva issued a decree banning the ethnic Chinese in the colony from residing and operating businesses outside of the specified customs posts and towns. ${ }^{2}$ This meant that Hakka families that remained in Maubara following the disaster of I893 could no longer own plantations and were restricted to trading in the town and the coastal hamlets of Daire and Vatuboro. Additional regulations targeting the ethnic Chinese soon followed, including a new law on Chinese-run gambling in Maubara. ${ }^{3}$ Second, Silva followed through on the plans originally formulated in I886 and put on paper in I893 for the construction of a military command post on the mountain in Guguleur. The aim was to restore order after the devastation caused the previous year and to safeguard the newly seized Crown lands slated for intensive coffee cultivation. ${ }^{4}$ Third, during the late I89os the colonial administration sought to improve basic infrastructure in Maubara: roadworks were undertaken, money was allocated for the construction of a residence for a Catholic priest and a church-run school, and in I90o a telegraph line was installed between Dili and the town of Maubara, and subsequently extended from Maubara into the Loes Valley. ${ }^{5}$

The centerpiece of Governor Silva's approach to the colony was a series of military operations to "pacify" various kingdoms, first in the western part of the territory and thereafter in the east. In doing so he drew on the limited first-line colonial troops together with larger numbers of second-line troops and irregulars called up from loyal kingdoms. As the new régulo of Maubara, José Rodriques da Silva participated in several of these operations, including the I895-I896 war against kingdoms in the western districts. ${ }^{6}$ José Rodriques da Silva died sometime around I898 or I899, however, possibly as a result of corporal punishment meted out by the Portuguese authorities for his negligent handling of weapons belonging to the colonial military. ${ }^{7}$ He was succeeded by his eldest son, Luis da Silva Maia, though the appointment was as régulo of the newly created jurisdiction of Maubara Taçi, not the entire Kingdom of Maubara. ${ }^{8}$ Like his father, Luis was a willing servant of the Portuguese administration and participated in the I899 campaign against neighboring Atabae, where 
rebels were holed up in the Fatubuikaren escarpment that had served as Maubute's last refuge and place of execution six years before. ${ }^{9}$

Coinciding with Luis's short term as régulo, the colonial regime began to develop a new approach to local administration in the richest coffee growing regions on the north coast. The Chinese business communities in the towns of Aipello, Liquica and Maubara were organized into municipal commissions. These commissions were authorized to levy taxes on fixed and mobile businesses, regulate gambling, impose fines for various offenses, and charge fees for use of the new telephone service. This revenue was allocated to pay a few civil servants (a teacher, telephone and postal workers, and a supervisor of public works), to finance infrastructural development (roadworks, the installation of petroleum lamps in town), to provide a modest budget for the new state and church-run schools, and to pay for rations for the indigenous second-line military personnel.10 As régulo, Luis da Silva Maia proved to be just as brutal as his father and reportedly committed a series of abuses against the local population. These misdeeds did not go unnoticed, and in I9oo the Portuguese administration felt compelled to remove Luis from office, charging him with "the murder of several indigenous people in the kingdom" and "rebellion," and eventually imprisoning him in Vemasse, a coastal town located in the eastern region. ${ }^{11}$

In place of the long-standing practice of indirect rule via a single régulo with authority to collect tribute throughout the entire kingdom, Governor Silva experimented with new forms of direct taxation. Soon after Luis da Silva Maia was removed from office Liquica district became a test case for the introduction of a head tax (imposto de capitação). A report in the colonial gazette shows that by 1902 there were already 2,239 males over the age of sixteen liable to pay the head tax in Maubara. ${ }^{12}$ Taking into account the likelihood that some males were simply not counted or managed to evade the rolls, this suggests that the total population of Maubara at the time was greater than ten thousand people. Taxation, in turn, required new forms of local administration. The kingdom was divided into two "jurisdictions"-Maubara Taçi and Guguleur-each containing four village-level administrative units (suco) with appointed headmen. This new arrangement reduced the position of régulo to little more than an intermediary between the local military commander and the 
appointed village heads. This presented new opportunities for the leading families to reassert themselves within the village-level administrative units. In I9o the Portuguese appointed a new chief in the coastal hamlet of Daire and a new head of the Chinese community in Maubara Villa. ${ }^{13}$ In Guguleur, D. Repreto's son-in-law, Mau Kura, was appointed chefe de suco of Guguleur. ${ }^{14}$ At about the same time D. Carlos's son, Sada Bessi, became chefe de suco of Vatuvou and was recognized as the coronel regente, though like his predecessor he too was dismissed for abuse of office in I907. ${ }^{15}$ The Portuguese may have hoped that these appointments would reduce friction between competing nobles, but the primary aim was to facilitate the collection of more accurate data about the population so that it could be taxed and labor allocated to the burgeoning coffee industry.

With the end of Celestino da Silva's long tenure as governor in I908 and the arrival of his replacement, Eduardo Marquez, the Doutels experienced a sudden reversal of fortunes. José dos Santos, the eldest son of the deceased D. Repreto, had studied at the Portuguese school for the sons of liurai in Lahane, and in I9o8 was posted as the telephone operator in Maubara. The next year, as part of Marquez's effort to redress many of the long-standing grievances concerning political appointments and the poor treatment of the indigenous polities, the authorities in Dili made a surprising decision to nominate José dos Santos to become the new régulo of Maubara. After consultations were held with members of the leading families in Maubara, he was formally installed as régulo in June I9Io. ${ }^{16}$

For José dos Santos and the house King of All, Brave King the timing could not have been worse. Four months later, in October I9Io, the Portuguese monarchy was overthrown and a republic was proclaimed. It took three weeks for Governor Alfredo Cardoso Soveral Martins to make a public announcement in Dili about the republican revolution and issue instructions for a series of cosmetic changes to remove monarchist symbols from official titles, colonial uniforms, and letterhead. News of the republic was celebrated by many of the Portuguese deportees in the colony, among whom there were a number of committed republicans as well as a few anarcho-syndicalists who had cheered the 1908 regicide in Lisbon. But the news came as a shock to loyal monarchists who staffed senior positions in the administration. The end of the monarchy was also a heavy 


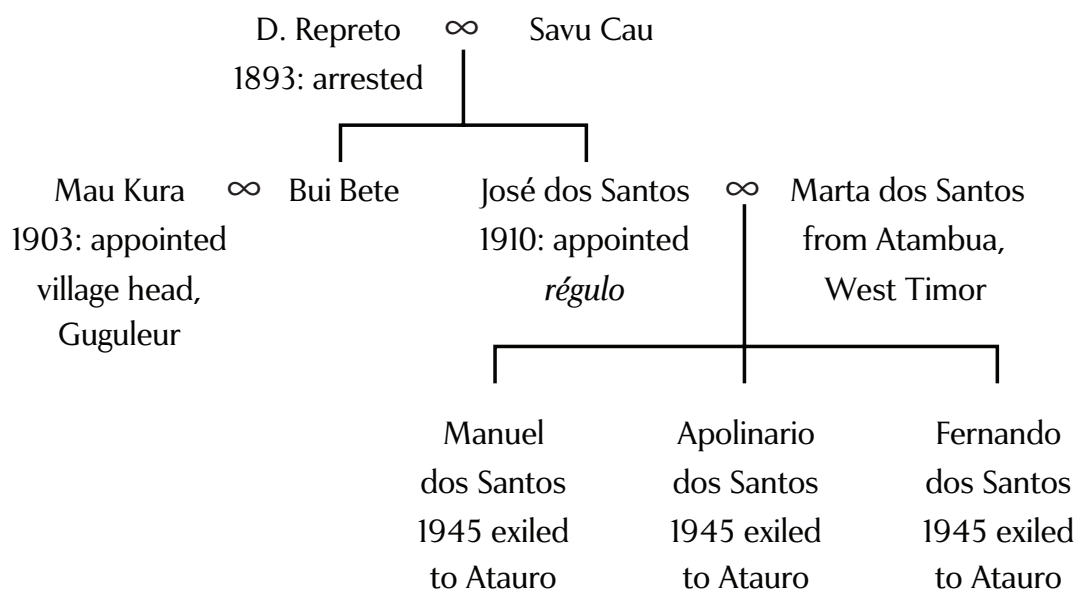

FIGURE 7 Doutel lineage, early twentieth century

blow to many of the indigenous ruling families who regarded royal patents and the monarchist flag as sacred items and feared that their privileged positions would come under threat.

A year later, anxieties about the new republican attack on monarchism combined with a sharp increase in the head tax drove a number of régulo and new-style chefe de suco in the southern districts of Covalima and Manufahi to launch an uprising against Portuguese authority. The rebellion lacked central leadership and coordination, but indigenous elites elsewhere in Timor followed the example set in the south-central region to launch uprisings of their own. One such site of open hostility to the Portuguese was the village of Vatuboro in Maubara..$^{17}$ Given the small size and limited resources of the colonial military, Governor Filomeno da Câmara called on the district military commanders and the loyal indigenous rulers to raise traditional forces (arraias). The war party from Maubara, under the command of the resident Portuguese priest Manuel Alves Ferreira, joined the expeditionary column marching from Dili to the south, and during combat in the Aituto forests of Aileu Ferreira was killed in action. ${ }^{18}$ The Great Rebellion, as it came to be known, was crushed at an enormous cost in life and property. ${ }^{19}$

For all the enthusiasm and fear occasioned by the events of I9IOI9I2, the Republican attack on monarchism and the position of régulos 


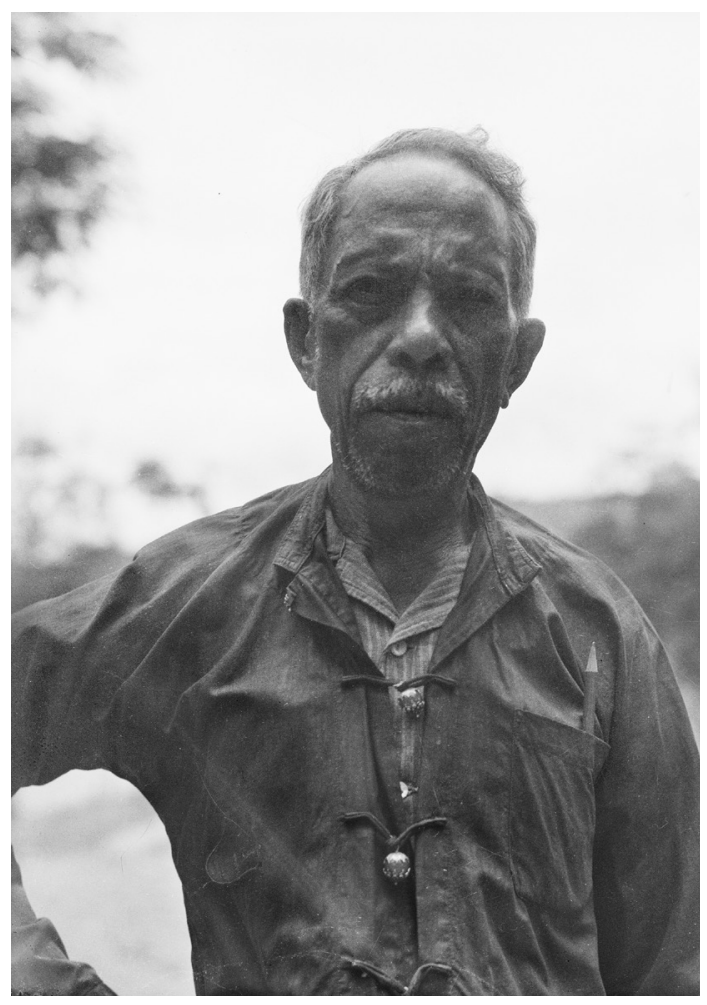

FIGURE 8 Regulo José Nunes, ca. 1945 (courtesy of the Australian War Memorial)

in Timor was short-lived. As the new administration enthusiastically embraced economic and administrative reforms, officials realized that economic rationalization could benefit from maintaining the façade of indigenous political figureheads now put in the full service of the colonial state. As in parts of Angola and Mozambique during roughly the same period, the result was a highly dependent neotraditional revival of dynastic rule, often involving the appointment of individuals from nonroyal lineages who were increasingly divorced from real social prestige. ${ }^{20}$ In Maubara the central figure in this revival was an ambitious young man from the hamlet of Nuno-Ana in Vaviquinia who set his eye on displacing José dos Santos as régulo. ${ }^{21}$ Born in I874, Mau Soko was the godson of the deposed régulo Luis da Silva Maia, and was later baptized with the name José Nunes. Nunes graduated from the Lahane primary school in Dili in I897, and therefore spoke Portuguese and was familiar with the colonial administration and culture. ${ }^{22}$ In I9Io, when José dos Santos was installed 
as the new régulo of Maubara, José Nunes was appointed as the new telephone operator in Maubara. Thereafter Nunes earned the rank of major in the second-line colonial military and in I9II-I9I2 participated in the Portuguese military campaign against Manufahi. By I9I2, José dos Santos of the Doutel family was ill and rarely came down from his home in the upper reaches of the mountain to attend to official business in town. Seeing an opportunity, José Nunes asked the Portuguese administrator to appoint him as régulo, promising he would be a more active and reliable servant of the regime. The administrator told Nunes he would need to provide strong evidence that he was deserving of the post. According to one elder in Maubara, "José Nunes explained to his godfather, the former régulo Luis da Silva Maia, that the Portuguese had asked him to provide proof. Luis said that the proof José Nunes needed was in the grave of Luis' father, Mauvili [José Rodrigues da Silva]. The posto administrator then gathered the populace from all the villages in Maubara to witness the exhumation, so they could see for themselves. They dug up the grave and found the patete, the sign of the rank of major. The chefe do posto then said 'You are now the real king here."”23

This account suggests that for both the Portuguese administrators and at least some in the local population sacred items and family heirlooms continued to convey legitimacy. Anthropologist Ricardo Roque argues that during the late nineteenth and early twentieth centuries the colonial administration became thoroughly complicit in indigenous cultural and political practices. Colonial officials and military officers promoted the use of Timorese "styles and customs" (usos e customes), including indigenous ritual practices and the taking of enemy heads. ${ }^{24}$ That the Portuguese administrator in Maubara viewed possession of traditional symbols of authority as a basis for making political appointments may be read as one more example of this entwinement between colonizer and colonized. But we must be cautious about taking oral accounts at face value. The story of the exhumation and appropriation of royal insignia may merely demonstrate the lengths to which claimants to power might go to dupe newly arrived Portuguese officials and to cloak their collaboration. What is clear is that José Nunes-who had been granted the official title Dom and office of régulo-was a beneficiary of the state-sanctioned revival of the outer trappings of monarchism. 


\section{Land, Coffee Planters, and Marginalization}

The central component of pacification was neither military occupation nor the establishment of a colonial bureaucracy, but rather land and the imposition of mandatory labor services by the indigenous population on the coffee plantations. Under Governor Silva large tracts of land were alienated, some through outright seizure and others through forced sales. The recipients of these grants and sales of land were a mixed lot, including both Portuguese officials and deportees (deportados and degredados) who represented the dregs of white society in the colony. Several of the early planters in Maubara deserve particular note, both to situate the changing social relations and because their descendants figure in subsequent periods of mass violence.

Governor Silva's son, Julio Celestino de Montalvão e Silva, was an officer in the Portuguese navy and followed his father to Timor, where he was appointed captain of ports. ${ }^{25}$ Oversight of the small Dili port provided few economic opportunities, so the governor's son quickly took an interest in coffee. He managed his father's enormous Sociedade Agrícola Pátria e Trabalho (SAPT) plantation in Fatubessi, Ermera, and was granted his own plantation in the upper reaches of Guguleur village, in Maubara. In Guguleur, he took a young woman named Lo Bete (baptized Madalena), who was the daughter of a dato (noble) from the hamlet of Uatumori, in Guguleur village, as his mistress and moved her to his home in Fatubessi. ${ }^{26}$ Another of the early Portuguese military officers who obtained land in Maubara was Leovigildo de Ladislau Mascarenhas Inglês (I859-I9I2). Deported from Portugal because of his pro-Republican activities, he arrived in Timor in I9OI. ${ }^{27}$ Mascarenhas Inglês served as a manager on the massive SAPT coffee plantation in Fatubessi and then obtained his own tract of land in Guico village, on the southern slopes of Mount Maubara, on which to establish a plantation. ${ }^{28}$ The enterprise never bore fruit and he soon sold part of his property and leased the rest to two new Portuguese arrivals: José Joaquim Chaves (I877-1930), who was deported from Portugal to Timor in about I905, ${ }^{29}$ and Antonio José Brites (I876-I94I), who is said to have been an illiterate adventurer. ${ }^{30}$ Yet another Portuguese military officer turned planter was a man from Macau named Zeferino Antonio Carrion who served in the colonial military in the late nineteenth century. In 1905 he 
purchased a four-hundred-hectare tract of land on the south side of the mountain ridge in Maubaralissa on which to develop a coffee plantation. ${ }^{31}$ Finally, a Portuguese military officer named Antonio Eduardo da Silva, who had served in Maubara in I892-I893, obtained several large pieces of land in the upper reaches of the mountain. ${ }^{32}$

The presence of these new planters and the booming coffee industry altered the political and sociological landscape in Maubara. In I907, when the Portuguese colonial administration conducted the first modern census in Timor, the population of Maubara included seven whites, no mestizos, three "blacks" (preto, i.e., Africans) and twenty-seven "yellows" (amarelo, i.e., Chinese). ${ }^{33}$ Five of the white men in Maubara were the officer-planters discussed above. Another, it is safe to assume, was the Portuguese military commander. The seventh white man must have been Father Manuel Alves Ferreira, a Catholic priest who arrived in Timor in late I905 and the next year became the first missionary to reside permanently in Maubara. Despite the fact that the well-built Dutch church was located on the beach near the fort and administrative office, Father Ferreira eschewed the heat of the coast for the cool mountain air and built a thatch-roofed chapel nearly adjacent to Lauwana. ${ }^{34}$ Within a few years, most of the Portuguese planters had taken local wives or mistresses (and in some cases both) and began to father the first generation of mestizo children. The three "blacks" in the census were undoubtedly soldiers from the African colonies serving in the Portuguese military.

The years after the declaration of the Portuguese Republic saw sharp increases in the head tax, the rapid expansion of Portuguese coffee plantations, and increasingly organized use of forced labor throughout much of the colony, and Maubara was no exception. ${ }^{35}$ By I9I3 the number of males in the subdistrict who paid the head tax had increased to 4,395 individuals (representing nearly a Ioo percent increase over the number a decade earlier) and the population had grown to I5,I3I. Although there were still only a handful of white planters, in I9I3 there were already fortythree "mistos" (lit. "mixed," i.e., mestizos), almost certainly all children. ${ }^{36}$ The Chinese population also rose from twenty-seven in 1907 to sixty-one in I9I3. ${ }^{37}$ The year before, colonial documents reveal, there were already fifteen Chinese businesses in the town of Maubara, of which fourteen were owned by married men and one by a widow. ${ }^{38}$ By I927, the combination of 
new migrants and second-generation children had boosted the Chinese population to I6o individuals.

During the I9IOs and I920s a new cohort of Portuguese and other European men joined the ranks of the landowners in Maubara. These included new deportees from Portugal and a handful of foreign men from places as far afield as Australia, New Zealand, Ireland, and Germany. ${ }^{39}$ One of the new arrivals merits special attention. Joaquim Sanches was born in Guarda, Portugal in I87I. He was deported to Timor in about 1905, according to some accounts for pro-Republican activities and in others for being an anarchist. Given the severe shortage of Portuguese men to staff the colonial bureaucracy and military, soon after his arrival in Timor Sanches was granted "reformed" status and was inducted into the Portuguese military as a second sergeant. He appears briefly in a scathing attack against Governor Celestino da Silva written by a Portuguese doctor, António de Paiva Gomes, that was published in Dili in 1909 under the pseudonym Zola.

In the first week of November $1906,{ }^{40}$ on the plantation belonging to Celestino I in Aileu, the foreman 2nd Sergeant (reformed) Joaquim Sanches ordered that the chief of Tatu-Bessi village (which is an agglomeration of tiny hamlets) be detained. The motive: the chief had not presented to the foreman a man who had been requisitioned.

The mangy chief, named Lequebére, was 50 years old. And in so far as he had submitted at the time of this tragedy, he had two sons in the service of the same plantation.

He was imprisoned by the moradores [second-line troops] of Railette at the military post, which, as I said, was in the area of the feitoria [trading post] for this purpose.

In Tatu-Bessi, the said sergeant sent the prisoner to the commander of Hatolia. Hands tied behind his back, hanging down from which was a rope, held by two soldier escorts.

As the forces were about to depart Joaquim Sanches cautioned by noting: "If the prisoner attempts to escape, you know, the cost is that you will be overwhelmed by arms." The death sentence is preferable to this. ${ }^{41}$ 
After his brief stint in Aileu, Joaquim Sanches was employed as a foreman in Fatubessi, presumably on the massive SAPT plantation, where his next opportunity was to arise. ${ }^{42}$ In I908 Governor Celestino da Silva's long and brutal tenure as governor came to an end and he returned home to Portugal. The following year his son Julio Montalvão e Silva also returned to Portugal, leaving his mistress, Madalena, and their two young children, Jesuina and Alberto, behind. According to oral accounts, Madalena decided to return to her parents' home in Uatumori, Guguleur, not far from the new Portuguese military post in Lauvei. Several loyal servants escorted Madalena and her children from Fatubessi down into the Loes Valley and on to Maubara. In the dry river valley the group met a man who asked where they were going. The escorts explained that the father of the two children had died (which was not true), so they were returning to the woman's parents in Maubara (which was true). The man then asked what was in the horses' saddlebags, which looked extremely heavy. The escorts said the bags contained stones. In fact, according to the oral account, the bags were filled with coins and gold that Julio Montalvão e Silva had given to his mistress, together with his plantation in Guguleur, when he departed for Portugal. ${ }^{43}$

Joaquim Sanches knew an opportunity when he saw one and promptly married Madalena. ${ }^{44}$ Her two children by Julio Montalvão e Silva were given the surname Sanches, and it appears that every effort was made to coverup the couple's connections to Governor Silva, his son, and the source of their wealth. The Sanches family settled into a large house, ${ }^{45}$ with spectacular views out to sea, and ran the massive coffee plantation that had originally belonged to Julio Montalvão e Silva. ${ }^{46}$ Over the years the couple produced nine children of their own. Like the other Portuguese planters, they relied on the subdistrict administrator, his indigenous police force, and the local chefe de suco to ensure a regular and docile supply of labor. The coffee business was sufficiently profitable that Joaquim Sanches could afford to construct a stately stone house facing the public square in the district seat of Liquica and send their children to the Portuguese schools in Liquica and Dili. Beginning in the I930s, the Sanches daughters married Portuguese men, while the sons, for whom white women were in short supply, married the daughters of local noble families or those of local Chinese merchants. ${ }^{47}$ 
The transfer of land to Portuguese planters, the burden of the head tax, and mandatory labor services instituted in the name of the civilizing mission combined to subordinate the local population to administrative controls and the dictates of coffee production. Alongside these economic changes, the colonial regime employed a combination of religion, custom, and law to transform the local population from subjects of the Kingdom of Maubara into homogenous "natives" of the empire. As part of his initiative to undermine the authority of the régulos and promote productive labor, in the I89os and first years of the twentieth century Governor Silva had issued detailed instructions to the military commanders to encourage application of Portuguese law in place of "customary" practices. Silva and his successors hoped to discourage payment of the traditional bride price and funerary sacrifices, and they encouraged the civilizing mission of the Catholic priests. ${ }^{48}$ After I9IO, Republican sentiment reversed many of these views, and "custom" became a central element of colonial policy. Much like the influence exerted by the Leiden Adat School in the Netherlands Indies, colonial officials came to view the codification of indigenous customs as a means by which to distance and regulate the local population. To this end, in I9I6 the colonial gazette began to publish lengthy reports by colonial officials or members of the clergy on local customes juridicos (juridical customs), and one of the first regions covered was Maubara. ${ }^{49}$ The following year the gazette ran a much more detailed eight-part series on customs in Maubara, including marriage practices, funeral ceremonies, property, and contracts. Political organization, however, was addressed in the most general of terms and without any consideration for actual history. ${ }^{50}$

With the rise of Salazar's quasi-fascist New State in the late I920s, the marginalization of the indigenous population became fully codified in juridical categories distinguishing the indigena (which could refer to the "native," "unassimiliated," or "uncivilized” population) and não-indigena (the "civilized" population, including both whites as well as mestizos and the few natives who had been granted assimilated status). ${ }^{51}$ Where the seizure of land and the regulation of labor subordinated the population in the economic realm, the use of custom and exclusionary cultural and legal categories completed marginalization in the realm of ideology. 


\section{Occupation and Exile}

The onset of the Second World War brought yet another brutal shock to the people of Portuguese Timor. In an attempt to prevent its territories from becoming part of the theater of war, the Salazar regime in Lisbon declared its neutrality. On the other side of the world, however, the declaration was soon ignored. In December I94I a small contingent of Australian and Dutch troops entered Portuguese Timor to deter a Japanese advance. Upon arriving in Dili, the Australians fanned out along the north coast, with one team traveling west to Liquica district. Bernard Callinan, who was a commanding officer in the company, later wrote a book about the resistance that included the following description:

We did not remain long in Liquissa, but drove on to Maubara, located at the end of the road-and indeed it looked like it! The buildings were dilapidated and the inhabitants were few. A couple of us walked into the only open building we could see and found it to be a Chinese shop. The occupants were distressed to see such martial figures and insisted on producing coffee and cakes whilst an old man told me how very old and ill he was, and that the only other occupants were women and children, flocks of whom were produced for our inspection. Feeling very embarrassed, we beat a retreat as soon as courtesy permitted after the refreshments. ${ }^{52}$

Portugal's declaration of neutrality was ignored once again in February I942 when the Japanese military, having already steamrolled its way through the Netherlands Indies, invaded the colony. Japan viewed Timor as a key stepping stone in its occupation of the entire eastern archipelago and as a strategic position of its defenses against an Allied advance northward from Australia. Accommodating the fiction of Lisbon's neutrality, the Japanese allowed the Portuguese governor to remain in office and Liquica district, where the white plantation owners exerted powerful influence, formally remained under Portuguese jurisdiction. The Japanese military mobilized large indigenous war parties, referred to as "black columns," to assist in operations against the Australian company that had retreated into the mountains to carry out guerrilla resistance. A small number of Portuguese residents of Timor with antifascist views aided the Australians, and after the withdrawal of Australian troops 
in 1943 some tried to keep the resistance alive. As a result of this, the Japanese military required all Portuguese citizens to be quarantined in Liquica and Maubara. The Japanese military also established a large detention camp, located in Banitur, on the northern banks of the Loes River, where an estimated five thousand ethnic Chinese were detained. Many died of hunger or disease. ${ }^{53}$ In Maubara, forced labor was employed to construct new rice paddies and irrigation in Guico village, and "comfort women" were recruited to serve the Japanese military officers and troops. ${ }^{54}$

Timorese responses to the Japanese occupation varied considerably. A number of ruling families that historically had close relations with the Portuguese or had benefited from political appointments after I9Io sought to defend Portuguese interests. Other elite families, however, viewed the occupation as an opportunity to take revenge against Portuguese officials, missionaries and plantation owners. In Maubara the brutal occupation reignited divisions among local elites. Régulo José Nunes retained his position thanks to the Japanese decision to recognize the Portuguese administration in Liquica, though apparently did what he could to protect the local population from abuses and was sympathetic to the Australian troops in the mountains. Members of the old ruling family in Guguleur, on the other hand, may not have viewed the Japanese as liberators but welcomed the displacement of the hated Portuguese regime. As the Japanese position worsened in early I945, José dos Santos's three grown sons-Manuel, Apolinario, and Fernando-are alleged to have plotted to kill Portuguese officials and install the eldest of the brothers, Manuel, as régulo of the kingdom. The plan does not seem to have been put into action, and with the Japanese surrender in I945, Portuguese officials rushed to reclaim their colony and reassert control. Benefiting from the accident of Japanese policy in Liquica more than his own actions, régulo José Nunes was granted state honors for upholding Portuguese sovereignty and pride. ${ }^{55}$ Learning of the royalist plot in Guguleur, the Portuguese administration arrested the three Doutel brothers and exiled them, together with hundreds of other elites from around the colony, to the offshore island of Atauro. ${ }^{56}$ Neither written nor oral sources provide details about the source or content of the charges against the brothers. It may be that Portuguese citizens living in Maubara had direct knowledge of the royal plot, but it seems more likely that José Nunes reported (and perhaps embellished) the plot to the 
Portuguese administrator as a way to eliminate his local rivals and consolidate his own position and claim to indigenous authority.

During the postwar years, Portugal doggedly fought a rearguard action against growing international calls for decolonization. Determined to retain its imperial grandeur, and convinced of its own ideology of Lusotropicalism, ${ }^{57}$ the Salazar government renamed the colonies "overseas provinces" and a new wave of officials and military personnel were sent to Timor. At the farthest reaches of the empire, the colonial regime sought to develop the territory, and there were modest increases in public education, basic infrastructure, and health care. The defining characteristics of Portuguese Timor, however, remained its underdevelopment, which was a function of geographic isolation and Portugal's own feeble economy.

Repression in the late I940s and I950s was not limited to those who had collaborated with the Japanese. As Portugal sought to fend off international calls for decolonization, the regime in Lisbon felt compelled to demonstrate a developmental agenda and introduced the state secret police, PIDE, to prevent any form of dissent. ${ }^{58}$ Indigenous elites were coopted once again to serve the colonial administration. In Maubara, régulo José Nunes died at the age of seventy-eight in 1952 and was succeeded by his son, Gaspar Correia da Silva Nunes. At the village level, individuals with the right pedigree and demonstrated loyalty to the Portuguese administration were installed as chefe de suco. Most of these men were drawn from the small circle of prominent families. One of Gaspar Nunes's relatives was appointed village head in Vaviquinia, D. Carlos's grandson Lucana was appointed village head Vatuvou, Mauvili's grandson Alarico da Silva was appointed village head in Maubaralissa, and in both Guico and Lissadilla individuals from the old dato families were installed in office (see table 3). The one exception was the village of Guguleur. With the exile of the three oldest sons, the Doutels were displaced yet again from villagelevel leadership. In their place, Madalena Sanches's brother Berdade was appointed chefe de suco. Formally responsible for collecting census data and the yearly head tax, his most important function was to recruit indigenous labor to serve the coffee planters, of which the Sanches's estate was among the largest and clearly the best connected.

Despite the brutality of forced labor, the onerous head tax, and the ceaseless struggle to produce enough food to feed families, throughout the 
TABLE 3

Village Heads in Maubara, Circa 1952

\begin{tabular}{lll}
\multicolumn{1}{c}{ Village } & \multicolumn{1}{c}{ Village head } & \multicolumn{1}{c}{ Background } \\
\hline $\begin{array}{l}\text { Guguleur } \\
\text { Vatuvou }\end{array}$ & Bere Dade (Berdade) & Lower dato family \\
Guico & Lucana (Lucas Correia) & Liurai, son of Sada Bessi \\
Lissadilla & Mau Buça & Dato family? \\
Maubaralissa & Mau Buça & Dato family \\
& Alarico da Silva & Liurai, grandson of \\
Vaviquinia & Ussi Vili & Mauvili \\
Vatuboro & Carlos da Costa & Relative of José Nunes
\end{tabular}

Source: Kevin Sherlock, "East Timor: liurais and chefes de suco" (unpublished manuscript, 1983), 28-3I.

I950s and I960s the old indigenous polities remained internally fractured and cross-kingdom and interethnic solidarities had yet to emerge. Resistance may have been impossible, but there are a few instances in which people in Maubara did seek redress for the injustices committed by the local authorities and the white plantation owners. In 1967, for example, villagers in Guico who were angered by the forced labor duties on the plantations appealed to a local Catholic priest. The case made its way to Bishop Ribeiro in Dili, who gave the group's leaders a copy of the Portuguese constitution so they would know their legal rights and who is alleged to have said that decolonization could not be averted forever. ${ }^{59}$ Informants today are not certain what this meant to their relatives at the time, but now interpret the incident as presaging events in the I970s.

A few years after the protest over forced labor, members of the Doutel family challenged a newly arrived Portuguese military officer named Abilio Bessa over land rights. ${ }^{60}$ Bessa had arrived in Timor in the early I970s to serve in the colonial army, but because of a shortage of teachers to staff the state schools he was assigned to teach at the newly established primary school in Etivou, Maubara. Soon after taking up his post, Bessa married a woman named Nicas dos Santos from the Doutel family. ${ }^{61}$ One day malae Bessa and 
a surveyor came to Lakudole (the location where Maubute was buried) to measure a plot of land that had either been granted by the colonial government or that he intended to purchase. Mau Kuru and his brother Mau Dila confronted Bessa and his team and said that the land belonged to their family and was not for sale, then seized the men's tape measure and other surveying tools. Malae Bessa informed the subdistrict administrator, Adelino Tinoco, who sent men to beat up the brothers. The case eventually made its way to the tribunal in Dili. According to family members, the judge ordered that the land be returned to its rightful owners, but this decision was never enforced.

These cases in Guico and Guguleur were entirely local affairs. There is no evidence that local actions in defense of land and in protest over labor practices ever resulted in suprahamlet discussions about property rights or organization; nor is there any evidence to suggest that people in Maubara were aware of international calls for Portugal to decolonize or the nationalist struggles for independence then under way in Portugal's African colonies. Unlike in colonial Angola and Mozambique, the co-optation of traditional forms of authority did not give rise to pan-ethnic solidarities. In fact, the people of Maubara and much of Timor seem to have known very little about even their nearest neighbor, Indonesia, where President Sukarno championed full decolonization and the struggle against Western imperialism during the I950s and early I960s, or for that matter the brutal counterrevolution of I965-I968 that brought General Suharto to power. Firsthand accounts of Portuguese Timor in the I950s and I960s read much like the grim depictions provided by Alfred Russell Wallace in the I850s and Joseph Conrad a few decades later. ${ }^{62}$

\section{The Adventures of Mao Klao}

With few opportunities for education beyond primary school and the virtual absence of print media in the I950s and I960s, discussion of indigenous rights and the possibility of self-determination was restricted to a tiny handful of young, educated men and women in Dili. The full significance of the backwardness of Portuguese rule is perhaps best illustrated by considering an exceptional individual who, born in Maubara, combined romantic visions of dynastic glory with modern notions of colonial oppression and human rights to champion the right to self-determination. These imaginings were made possible, however, only by moving beyond the confines of Portuguese Timor. 
Muhammad Saleh Akbar Balikh was born in 1938 in the hamlet of Morae, a few kilometers west of the town of Maubara, to parents who had migrated from the island of Pantar in the Netherlands Indies. ${ }^{63}$ Fearing the Japanese invasion, in 1942 the family fled across the strait to Alor, where the parents were arrested by the Dutch (for reasons that are not known) and their four-year-old son wound up being adopted by relatives. "As a young boy," he later wrote, "I was registered in school and . . . my grandparents said that my place of birth was in Timor. I asked how it is that my birth was in Timor and my grandparents said that we grandchildren were born there, in Maubara, in the Portuguese colony of Timor. I was silent but always thought about this." ${ }^{64}$ Balikh completed primary school on Pantar, then attended the lower teaching training school in Kalabahi, on Alor, and was sent to senior high school in Kupang, in West Timor. He was a good student and in 1958 his relatives arranged for him to continue his education in Jakarta, the bustling and politically vibrant capital of Sukarno's Indonesia. Prior to his departure, relatives from Pantar and Adonara gathered to offer their blessings and advice. Balikh's written account explains,

After the Tarrong family from Adonara arrived, they held a prayer ceremony and the elders and traditional leaders gave me guidance for my travels and also instructions about returning to my home place. This guidance included the following. . . . M.S.A. Balikh may continue his education in Jakarta but must remember not only to go to school but also to make time to look after Timor, which is colonized by Portugal, because that is also your right and your inheritance from Oa Wato Wele and Lian Nura (Pati Golo Raja Arakiang), a handsome youth who moved from East Timor [Timor Timur] to the self-sufficient mountains/island of East Flores, where his throne and home are preserved in the District of East Flores, because he was the descendent of a Great Noble and also a descendent of Kings of the islands mentioned above.

This account seems to conflate real and imagined inheritances. The family that adopted Balikh traced their ancestry to a figure named Pati Golo Raja Arakiang, who may have lived in the seventeenth century when the people of Kingdom of Larantuka became allied with the Portuguese and converted to Catholicism while the Muslim principalities on Solor, Adonara, and adjoining islands became allied with the Dutch. ${ }^{65}$ Emelia Doutel, the 
princess from Maubara who was taken by the Dutch to Alor at the time of the 1859 territory exchange, may provide yet another link, though Balikh does not mention her. The young Balikh, therefore, seems to have drawn a direct connection between claims to a royal lineage with ties to Timor and his own place of birth in Maubara.

Not long after arriving in Jakarta in 1958 to continue his high school education, Balikh came into contact with individuals involved in Sukarno's campaign for the liberation of West Irian from the Dutch and the nascent movement for self-determination in the British colonies of Sarawak and Sabah in the northern part of Borneo. Following an impassioned speech by President Sukarno about the need to free the colonized territories of West Irian, North Kalimantan, and Portuguese Timor on 5 July 1959, Balikh and his friends met behind the Republic of Indonesia Radio station in Central Jakarta to discuss their cause. ${ }^{66}$ They named their movement the struggle for the Union of the Republic of Timor-Dilly (Uni Republik Timor-Dilly, URT-D). ${ }^{67}$ The group consisted of Balikh, two young men from Portuguese Timor (Emmanuel Maubere from Ermera and Simon Serang Pria from Maliana), and a few individuals from elsewhere in Indonesia. Balikh claims that military and intelligence officials occasionally visited the URT-D headquarters to offer encouragement.

Balikh graduated from senior high school in 1960 and then enrolled in Sawerigading University to study economics. But his real passion was now the liberation of Portuguese Timor. In early I96I Balikh and his friends hatched a daring plan to declare independence on behalf of their imagined compatriots. Balikh traveled from Jakarta to Bali by bus, flew to Kupang, and finally took a bus to the conspirators' meeting point in the town of Atambua, in West Timor. On 9 April the group snuck across the international border to Batugade, just inside Portuguese territory, where, before a crowd of about fifty puzzled locals, they raised the flag of the Unitary Republic of Timor (modeled on the US stars and stripes), and Balikh hurriedly read a two-sentence declaration: "We the people of Portugueseoccupied Timor proclaim independence. Other matters pertaining to the independence of Portuguese-occupied Timor will be arranged at a later date." ${ }^{18}$ When Portuguese officials in Batugade approached to determine the source of the commotion on the edge of town, the ragtag band of longdistance nationalists dispersed every which way, most eventually crossing back over the border to the town of Atambua. 
Although the adventure received little publicity, Balikh thought the declaration was a great success and was intent on building the movement into a full-blown government in exile. Having adopted the name Mao Klao, in 1963 he drew up an elaborate announcement about the formation of a Military Council of the Union of the Republic of Timor Dilly. It listed Mau Klao as the President of the Presidium, his friend Emmanuel Maubere as the Head of the Council, Balikh's wife Aminah as his deputy, and another twenty-one individuals (one of whom was listed as deceased) with ranks ranging from major to brigadier general. Further documentation followed. Mao Klao posed for an official photograph wearing a dark suit and tie, and under the image wrote by hand "Head of the Delegation of URT to the Republic of Indonesia." In 1964 he produced a sample one thousand pataca note, one side of which celebrated the i96I proclamation, with the reverse side bearing a crude sketch of armed men standing in Indonesian West Timor preparing to invade the Portuguese colony. During the late I96os Balikh sent formal letters to Indonesian officials congratulating them on their appointments and informing them about the aims of Unitary Republic of Timor. ${ }^{69}$

The Carnation Revolution in Lisbon in April 1974 and the sudden announcement of plans for immediate decolonization provided the impetus for the formation of the first political parties in Dili. Not to be left out, Mao Klao hatched a series of new political fantasies. In July 1974 he issued a constitution for the slightly renamed Union of the Republic of East Timor (Uni Republik Timor Timur). The most interesting feature of the imagined state was a bicameral legislature, with a lower house of elected representatives and an upper house reserved for the traditional kings (liurai). ${ }^{70} \mathrm{~A}$ year later Mao Klao issued a sloppily produced list of the names of the president, prime minister, and ministers in his government. The name "Ramos Horta" (presumably José Ramos-Horta, the well-educated, mestizo nationalist who served as Fretilin's minister of foreign affairs in 1975) appears on Mao Klao's list as both the minister of foreign affairs and deputy prime minister. ${ }^{71}$

At this point Mao Klao's narrative takes an even more bizarre turn. He claims that sometime in 1974 or 1975 the secretary general of the United Nations arrived in Jakarta and asked Mao Klao to accompany him to the border separating Indonesia and Portuguese Timor. Mao Klao's wife was about to give birth, so he declined the invitation. His wife than received a summons from the Jakarta chief of police, but became suspicious because 
the name on the summons was spelled incorrectly. While fellow activists were detained by the military and jailed, Mao Klao and his wife evaded the authorities by moving to a poor neighborhood in North Jakarta. In late 1975, however, Mao Klao was arrested and detained until April I976. It appears that Indonesian military intelligence feared that Mao Klao's unusual and highly public activities would bring unwanted attention to the brutal invasion and planned integration of Portuguese Timor into the Republic of Indonesia. After his release, Balikh remained interested in what was happening in his "homeland," but the territory was now under strict military control and he was not able to travel there.

Mao Klao's account and the detailed documents he produced attest to the model that Indonesia's own revolution and postindependence politics could have on the political imagination of one individual in the late Sukarno years and again in the early I970s. His imaginings combined the notion of royal ancestry and the image of the colonial "native." These are the same themes that dominated conceptions of power and powerlessness in Maubara at the time. But where education, the media, and official encouragement made possible Mao Klao's long-distance nationalism, in Maubara and most of Portuguese Timor very limited levels of development and strict control over information about the outside world kept grievances entirely local.

\section{Conclusion}

In the aftermath of Maubute's failed rebellion of I893 the Doutels witnessed the rise and fall of an upstart, rival house and ruler; the division of their former kingdom and the imposition of new village-level administrative units; a brief resurgence with the appointment of José dos Santos, followed by the antimonarchical declaration of the Republic in I9Io and massive operations to crush a territory-wide uprising. In the eyes of both the Portuguese and the indigenous population, the legitimacy of traditional rule had been greatly undermined. The appointment of José Nunes as régulo of Maubara marked the onset of neotraditionalism: the position of liurai/régulo was divorced from social norms and legitimacy and was now wholly dependent on the whims of the colonial regime. Indeed, the vast European-owned plantations that now dominated the landscape made a mockery of the notion of an indigenous lord of the land. The corollary to this was the odd marriage of local customs, 
that were documented and promoted, and, more gradually, conversion to Catholicism that served to distance and subordinate the "native" population. As Mahmood Mamdami argues in the context of colonialism in Africa, "native was used not to mean a person whose life had historically been governed by the customary law in question, but as a blanket racial category." 72

The heyday of foreign coffee planters resulted in the marginalization of the populace from their own land and, via the annual head tax, performance of onerous, mandatory labor services. The turmoil of the Japanese occupation allowed members of the Doutel family one last hope of expelling the Portuguese and reasserting their precedence and authority, but the plot was never put into action and the conspirators were exiled. For the general population, the result was the imposition of an even more ironclad colonial regime. Under these circumstances, the first nationalist stirrings came not from within Maubara or the colonial capital Dili, but from the tragicomic declarations of a man who, born in Maubara but raised in Indonesia, drew on appeals to royal ancestry and tradition as well as the lessons of radical Indonesian nationalism. He could fancy himself as both liberator and future ruler of a united republic of Timor.

These political landmarks, however, are only half the story. The greatest legacy of the early twentieth century for indigenous elites in Maubara was what did not happen: unlike the experience of prominent liurai/régulo families elsewhere along the north coast and the coffee-producing highlands, neither the Doutels in Guguleur nor the descendants of D. Carlos in Vatuvou benefited over time from Portuguese education and their daughters did not marry colonial officials or private Portuguese planters. They were, in other words, never provided with the means to move beyond their own locality into the emerging mestizo elite that slowly coalesced in Dili while retaining the vestiges of traditional authority in their home localities. The Doutel's uma lulik (sacred house) fell into disrepair, sacred objects were hidden away, and memories of their former prowess faded. The family's social transformation from King of All, Brave King to "half-saves in Oceania"73 and finally into colonial "natives" is best captured by an image. In the I950s, Mau Kuru and his brother Mau Dila posed for a photograph in front of the dilapidated Dutch fort wearing woven sarongs tied at the waist, sashes draped over their shoulder, headscarves, and feathers, one wearing a large metal medallion on his bare chest, the other holding a sword. 


\section{6}

\section{The End of Empire and the Indonesian Occupation, 1974-1998}

In the early I970s Maubara was still a very small place in a remote colony at the furthest edge of a vagabond empire whose continued existence owed more to its backwardness than anything the colonial masters had or could hope to accomplish. Social and economic structures in Portuguese Timor were little different from those of the I920s: a handful of Europeans administered the territory at a financial loss while privately profiting from vast coffee plantations. Nor were the material conditions in which the population lived far removed from those of the I720s. Subsistence agriculture produced a diet of tubers, vegetables, and only occasional meat; dwellings were still built of wood, bamboo, and thatch; and personal possessions were few. More children were now attending primary school, and a few might even become "native" clerks in the colonial administration or serve in the colonial military, but even the limited status of assimilado lay well out of reach of the people of Maubara.

All this was to change very rapidly beginning in 1974 when a military coup in Portugal opened the way to decolonization, rather nastily in mid-I975 when the newly formed East Timorese parties briefly fought one another, and brutally in late 1975 when the Indonesian military invaded Portuguese Timor. The result was a horrific foreign occupation that lasted twenty-four long years. The defining feature of the occupation was violence, which came in many forms. Much of the population of Maubara was displaced from their homes and forced to flee into the forests and valleys for two years, during which there was great loss of life, only then 
to surrender and face forced relocation to supervised places of habitation. Even after the population was allowed to return to their hamlets, there was the grinding repression of military operations, searches, summons, forced labor, and fear that one (or one's relatives) might be suspected of supporting the resistance.

Viewed in national terms, it is all too easy to see the Indonesian occupation as a single period dominated by the struggle between the colossal occupying regime and a brave but puny resistance. But viewed from below, the occupation was experienced in terms of a constant intertwining of local meanings, emerging national ideals, and adaptation to a foreign power. The past informed people's choices and individuals interpreted or appealed to the past to justify their positions and actions. The impact of the past on conflict is by no means uniform, of course. In antebellum America, for example, communities in the Shenandoah Valley had once hosted a variety of positions both for and against slavery, but with the outbreak of the Civil War they coalesced either in support of the Union or the Confederacy and young men marched off to war to defend those positions. ${ }^{1}$ In Maubara, by contrast, neither the sudden arrival of free political competition in 1974-I975 nor the Indonesian invasion a year later led the population to coalescence around a single, shared position. The relationship between local meaning (including claims, allegiances, and rivalries) and the emerging "national" ideal also varied greatly. Here, the experience in particular counties in China during its protracted revolution provides a point of comparison. William Rowe has shown how local elites and commoners alike could either engage with competing national claimants to power or withdraw and resist a greater center. ${ }^{2}$ But in East Timor in 1974-I975 the very idea of the nation was so new that it challenged old ideas about tradition, authority, and place. In contrast to both the American and Chinese circumstances, by late I975 Maubara was not involved in a civil war but rather foreign occupation, which meant that violence was commonly experienced in terms of collaboration or resistance, and, beyond Timor's shores, by positions colored by Cold War politics. 


\section{Carnations for Timor}

The Portuguese Empire was burst asunder from the most unlikely of sources: in April 1974, a coterie of left-leaning military officers demoralized by the hopeless colonial wars in the African colonies carried out a coup against the Caetano regime in Lisbon. The junta that seized power in the Carnation Revolution announced that decolonization would be carried out in the fastest time possible. In Dili, the announcement of imminent decolonization opened the door for East Timorese to form the first political associations. The two major parties were the pro-Portuguese Democratic Union of Timorese (União Democrática Timorense, UDT), founded on II May, and the more radically nationalist Timorese Social Democratic Association (Associação Social Democrática Timor, ASDT), formed on 2o May, which subsequently changed its name to the Revolutionary Front for an Independent East Timor (Frente Revolucionária do Timor-Leste Independente, abbreviated Fretilin). A third party, the Association for the Integration of Timor into Indonesia (Associação Integração di Timor-Indonesia, which later changed its name to the Timorese Popular Democratic Association, Associaçao Popular Democrática Timorense, Apodeti), was established on 27 May. $^{3}$

Elites in Maubara were quick to stake out positions in the new political parties. Their choices reflected long-standing local rivalries, connections to prominent national figures, and the new ideas about rights and self-determination. These factors were reflected both across village units and in a division between the north and south sides of the mountain.

The founding members of UDT included several individuals with deep roots in Liquica district. Mario and João Carrascalão were the sons of one of the largest and most powerful mestizo land-owning families in the colony and held positions in the colonial administration. ${ }^{4}$ Another UDT founder was Francisco Lopes da Cruz, who was born in Maubara (though his parents were from elsewhere in Timor) and spent his childhood at the Samarapo chapel, high on the mountain ridge where his father was a catechist. ${ }^{5}$ With such local notables in the party, it is not surprising that UDT attracted the small group of civil servants in Maubara, led by the mestizo chefe do posto, Adelino dos Santos Tinoco. ${ }^{6}$ The two major Portuguese-mestizo plantation-owning families on the north side of the 
mountain - the Sanches family in Lautekas and the related Goncalves family in nearby Bella Vista-supported UDT, as too did key members of the indigenous elite, including Gaspar Correia da Silva Nunes (the son of D. José Nunes) in Vaviquinia, Lucas Correia (grandson of D. Carlos) in Vatuvou, and Fernando, José Manuel, and Lucas dos Reis da Silva (all grandchildren of Mauvili) in Maubaralissa.

The only nationally prominent Fretilin leader from Maubara was Helio Pina. ${ }^{7}$ He was the grandson of the Portuguese deportee Joaquim Sanches and his Timorese wife Madalena, and the son of their daughter, Lucina Sanches, and João Ferreira Pina (1917-2004), a Portuguese man who served in the colonial military as a first sergeant and later as the subdistrict administrator of Suai. Helio Pina graduated from the state senior high school in Dili in 1969 and then won a government scholarship to study agriculture at the University of Évora in Portugal. There were a number of students from the African colonies at the university and Helio was soon attracted to the political left and the anticolonial struggle. Returning to Timor in February 1975, he adopted the indigenous name "Mau Kruma" (kruma meaning "short"), and was appointed to the Fretilin Central Committee. ${ }^{8}$

In Maubara, Fretilin attracted some sections of the traditional elite as well as many ordinary villagers. Support for the party was particularly strong on the south side of the mountain, where the Portuguese-mestizo planter families-the most prominent of which were the Carrion and Brites families-and several old dato families-the Lobos of Lissadilla and the descendants of Buru Bara in Guico-joined the party and played active leadership roles. There were also prominent UDT families that had renegade sons who joined Fretilin. José Cirilio Nunes, son of Gaspar Nunes, was serving in the colonial military at the time of the Carnation Revolution and, like many of the young recruits, joined Fretilin in late I975 and went on to take the nom de guerre Mau Brani (brani meaning "brave").

The pro-Indonesian party Apodeti, led by royal (liurai) families from Atsabe, Suai, Laclubar and parts of Viqueque, had only minimal popular support across the territory and never enjoyed a significant following in Maubara. In the hamlet of Caicasa, on the lower slopes of Guguleur, however, several young men did join the party. The most notable of these were Francisco Ribeiro and Leoneto Martins, who was a distant relative of the 
Doutels. Both of these men, as we will see, later rose to prominence during the Indonesian occupation. ${ }^{9}$

In Guguleur, the men in the Doutel clan were attracted to Fretilin's call for independence and economic programs based on self-sufficiency. In I974, Mau Kuru was thirty-nine years old and his brother Mau Dila (baptized Guilherme de Jesus Afonso) was forty, making them more than a decade older than the generation of Fretilin leaders. With no formal education and young children to feed, caring for family was a struggle and left little time and even less opportunity to engage directly with party leaders. Nevertheless, at some point in 1975 Mau Kuru did obtain a Fretilin party card..$^{10}$

In August 1975, after Indonesian intelligence had fanned mutual suspicions between the political parties, a faction within UDT led by João Carrascalão carried out a surprise "anti-communist movement" (Movimento Revolucionario Anti-communista) in Dili. The movement seized police headquarters and other government buildings and then attempted to arrest as many Fretilin figures as possible. ${ }^{11}$ Most of the Fretilin Central Committee members in Dili at the time escaped south to the mountains of Aileu, but over the following week UDT forces managed to arrest several hundred Fretilin supporters in Dili and the district towns. In order to consolidate its control, the movement's leaders specifically targeted East Timorese members of the police force who they believed to be pro-Fretilin. One such police officer was José Lino dos Reis, the grandson of Maubute's lieutenant Buru Bara, from Guico village in the southern part of Maubara. ${ }^{12}$ He was arrested on I2 August at his home in Malua, on the outskirts of Dili, and was detained in the Military Police barracks in Palapaço, near the Portuguese residential enclave of Farol, along with about two hundred other Fretilin members or sympathizers. ${ }^{13}$

In Maubara, local UDT figures Adelino Tinoco, liurai Gasper Nunes, brothers José and Joaquim Sanches, and João Pina met on II August and decided to follow the example of party leaders in Dili by conducting paramilitary sweeps to search for their political enemies. ${ }^{14}$ Anyone holding a UDT party card would be safe, while individuals with a Fretilin card were to be arrested. Most villagers, of course, did not have a card from any of the parties. Nevertheless, within days the UDT leaders had rounded up several hundred people who they detained inside the old Dutch fort facing the sea 
while a smaller number of local Fretilin cadres were held nearby inside the town's primary school..$^{15}$

The UDT action in Dili had succeeded based on surprise and the limited objective of seizing the capital, but the party lacked the capacity to extend its control further afield. Meanwhile, Fretilin leaders had enticed most of the East Timorese troops in the colonial military in the capital and the garrison in Aileu to resist the UDT action. Beginning on 20 August, Fretilin forces mounted a counterattack against UDT. To defend their positions, UDT set fire to houses in parts of the capital. José Lino's house was among those burned, forcing his wife to flee with their three young children to the forests around Daré Seminary, overlooking the city. On 2I August, in a strange turn-around, UDT leaders asked a number of the detained police officers to join their movement and offered them light arms. José Lino initially refused the offer, but thought better of it and finally agreed. Once released, he immediately went home but discovered that his house had been torched and was told by neighbors that his wife and children had fled. Taking a rolled up sleeping mat, he walked up to Daré to find them. Once he was certain that they were safe, he returned to Palapaço to report to the UDT leaders.

The next day, Francisco Lopes da Cruz, who had taken on a leading role in UDT's action, asked José Lino to go to Aileu to find out what the Fretilin leadership was planning. Thinking quickly, José Lino said that he was willing to do so but only after escorting his family to the safety of their home in Maubara. ${ }^{16}$ Lopes da Cruz, who was coordinating UDT's defenses in the capital, agreed and gave José Lino a written pass so that his vehicle would not be searched at the many UDT roadblocks to the west of Dili. When the family reached the town of Maubara, they encountered Liurai Gaspar Nunes and chefe do posto Adelino Tinoco in front of the Dutch fort with a large number of UDT militiamen. The UDT bosses had heard (incorrectly) that José Lino had resisted the advancing Fretilin forces in Daré, so were pleased to see him. To further win the trust of the UDT leaders, he told them, "Actually, all the Fretilin people here should be killed!" He explained to Nunes and Tinoco that he was going to take his wife Paulina and their children to Caicasa, but would return the next day to help resist the expected Fretilin advance on Maubara. Allowed to leave, he never returned, first hiding with his family near Caicasa, and 
several days later moving down the back slopes of the mountain to their home in Guico.

When the family reached Guico, Paulina informed her husband that she had brought a stack of about five hundred blank Fretilin membership cards that José Lino had been given while attending a meeting at Fretilin President Francisco Xavier do Amaral's house in Dili shortly before the UDT action. Paulina had hidden the cards in her belongings when she fled from their house in Malua to Daré. Hearing that the UDT leaders had conducted sweeps and confiscated villagers' membership cards, José Lino began to fill out and sign the new cards for relatives and friends who supported Fretilin. Word traveled quickly and soon people were coming from as far as Atabae subdistrict, to the west, to ask for cards. Some villagers even offered to pay, but José Lino insisted that they were free to genuine sympathizers-both male and female-and explained that those holding cards would have nothing to fear when Fretilin forces reached Maubara.

Over the course of fifteen months the old colonial order had been shattered and the people of Maubara had been thrust into the whirlwind of decolonization and political competition. Mass arrests created new fears and villages were fractured along party lines. The Sanches family's Portuguese background and economic privilege had naturally meant support for UDT. The Doutels' history of opposition to the Portuguese had translated into support for Fretilin. Lower down the mountain Francisco Ribeiro, Leonito Martins, and others sought their own path via affiliation with Apodeti and the idea of integration into Indonesia. The situation in other villages and hamlets was just as complex, reflecting internal divisions, intra-suco rivalries, and uncertainty about the course of events and the possible outcomes.

\section{Fretilin in Maubara}

The Fretilin counterattack, spearheaded by units from the colonial army that formed the core of Fretilin's newly established Armed Forces for the National Liberation of East Timor (Forças Armadas de Liberatação de TimorLeste, abbreviated Falintil), routed the UDT positions in Dili over the course of several days. Replicating the tactics employed by the anti-communist movement only weeks earlier, Fretilin leaders ordered the detention of as 


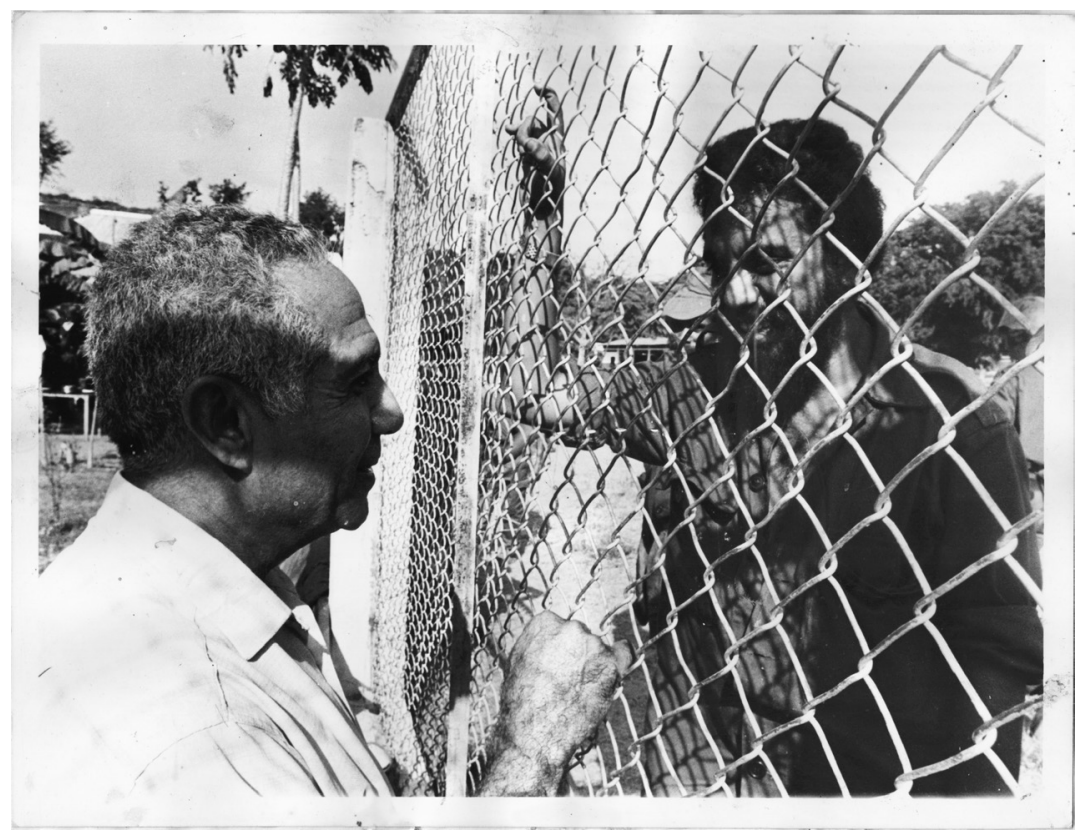

FIGURE 9 Helio Pina visiting his father in detention, 26 August 1975 (courtesy of Rui Pina)

many UDT supporters as they could lay their hands on. Many of the detainees were members of prominent mestizo families, including the scions of the coffee industry. João Pina of Maubara was among those arrested and detained at the Taibessi military barracks. On 26 August, Helio Pina visited his father and the two chatted cheerfully through the chain-link fence that separated jailor from prisoner, son from father. Meanwhile, the most prominent UDT figures, including João Carrascalão and Francisco Lopes da Cruz, together with several hundred armed men, managed to retreat from Dili to the town of Liquica. From there, Francisco Lopes da Cruz traveled to the Indonesian border where he met with Indonesian military officers on 2 September to appeal for Indonesia to assist the fifteen hundred "refugees" in the towns of Liquica and Maubara. ${ }^{17}$

Fretilin quickly mobilized its forces-which included both trained and uniformed Falintil troops as well as civilian militias-to pursue their adversaries. Their primary targets were the UDT strongholds of Liquica and Ermera. The town of Liquica was relatively well defended by a force with four hundred rifles and three mortars. But with limited munitions 
and fearing an imminent Fretilin attack, on 7 September UDT leaders decided to move their prisoners and several thousand civilian supporters from Liquica further west to the town of Maubara. After three days of Fretilin mortar attacks, on about II September the UDT forces in the town of Liquica ran out of munitions and Fretilin overran the town. Fretilin troops swept through the subdistrict, detaining hundreds of UDT members, and finally reached the town of Maubara on I5 September. ${ }^{18}$ Adelino Tinoco, João Carrascalão, and Gaspar Nunes narrowly escaped that day by boat from Morae, a small beachhead to the west of town, and motored to Indonesian West Timor. ${ }^{19}$ Some rank-and-file UDT supporters fled on trucks or on foot up the single lane track leading over Mount Maubara and down to the Loes River valley, from where they could continue to the border. Others, not so fortunate, were detained. ${ }^{20}$

Having captured the town of Maubara, Falintil and the civilian militia units launched sweeps for UDT supporters throughout the subdistrict. One militia patrol followed the main road leading from the town up the steep track to the village of Vatuvou, situated on the mountain ridge, where a gunfight occurred with UDT forces, and arrests were made in the hamlet of Gariana. ${ }^{21}$ Another team, under the command of Leonardo Alves, better known by the nom de guerre Ramahana, ${ }^{22}$ ascended the more difficult track from Morae, located a few kilometers west of town, to the village of Caicasa, and from there up the mountain to the hamlet of Lautekas. Turning at a fork in the track, Ramahana and his men reached the Sanches family home at Lauvei and searched for members of the prominent UDT family. The family patriarch, José Martinho Sanches, and his fourth son, also named José, had already been detained, so only the three oldest sons-José Alcino Sanches, ${ }^{23}$ Julio J. Sanches, and Joaquim J. Sanches-remained unaccounted for. Anticipating the Fretilin sweep, the three young men were hiding in the coffee plantation. Ramahana and his followers soon found the boys and executed them on the spot. The militiamen then descended the steep dirt track from Lautekas to the coast, where Ramahana and his men bragged about killing the Sanches brothers. ${ }^{24}$

Three young men hiding in a coffee plantation were not a threat to Ramahana and his men, nor were they a threat to Fretilin and the struggle for independence, so why were they murdered? Viewed in terms of a "national" narrative, the Sanches brothers were killed because they were 
from a prominent UDT family. But in dozens of oral interviews conducted in Maubara over the course of several years, individuals who were willing to speak about the killings repeatedly highlighted purely local factors. Several sources said that the family's ties to the much-hated Governor Celestino da Silva, who had seized or forced the sale of large tracts of land in Maubara, underlay popular resentment against the Sanches clan. Still other sources stress that villagers in Caicasa harbored long-standing resentment over the use of forced labor to work the Sanches' large coffee plantation and the alleged sexual abuses of village girls by the family's sons. ${ }^{25}$ These factors appear to have tipped the scales from arrest, which was the most common outcome when Fretilin supporters found political rivals, to murder.

By the evening of I5 September, Fretilin leaders had secured control over the northern part of Maubara, and within days Ramahana and his men swept through the villages along the Loes River as well. ${ }^{26}$ In less than a week control was extended over all of the western districts. With the evacuation of the Portuguese administration to the offshore island of Atauro in mid-August and the flight of UDT and Apodeti into Indonesian West Timor, Fretilin found itself in the unexpected, and largely unwanted, position of being the de facto government of the territory.

In September and October 1975 Indonesian military personnel conducted a series of covert operations into Portuguese Timor and warships entered the offshore waters near the international border at Motain. Fretilin Minister of Information Helio "Mau Kruma" Pina traveled from Dili to Balibo in October to inspect troops and assess the Indonesian positions. Mau Kruma was the black sheep of his family. He had seen his father imprisoned and he had undoubtedly been informed that three of his cousins had been murdered at the family homestead. Now, facing off with the vastly superior Indonesian military, his mind was consumed with organizational challenges. Portuguese journalist Adelino Gomes accompanied Mau Kruma on the trip and taped an interview at the eighteenth-century Portuguese fort in Balibo.

GOMES: We've been with you for more than 24 hours on our way to Batugade and I realize that in fact there are deficiencies in the organization of Fretilin. What I was asking myself is if this has to do with 
the fact that you started in a war-the military actions started only a month and a half ago-or if this has to do with other internal difficulties in the movement?

MAU KRUMA: At the organizational level, since the beginning Fretilin has tried to be a party that is as well organized as possible. It seems to me that the appearance of contradictions at the party level is part of the growth of the struggle. This is normal and logical at the moment, because we started before the 2oth of August as a more or less organized movement. At this phase in the struggle, which we can consider the national liberation phase, and therefore a superior phase of the political struggle, because of conditions we had to accept a whole range of comrades who in the beginning weren't integrated into our process. At the beginning this might create a certain amount of disorganization, which we are trying to overcome. And it seems to me that at this moment organization is possible in so far as the majority of the people are raising their consciousness on the real problem that Fretilin is trying to address, meaning, the struggle for national liberation. ${ }^{27}$

Abstract reflections on conditions, contradictions, and consciousness could not forestall the impending onslaught that Mau Kruma and his comrades were about to face. Only days later Indonesian forces overran the small town of Balibo, where they murdered five foreign television journalists covering the invasion. ${ }^{28}$

With Indonesian forces occupying Balibo and beginning to advance westward in the direction of the coastal town of Atabae, Fretilin commanders sent fresh troops to prevent them from crossing the Loes River. José Lino dos Reis, the police officer from Guico village, was put in command of a platoon of thirty men. ${ }^{29}$ Crossing the Loes River to Atabae, the platoon came under fire from Indonesian warships and retreated up the mountain in the direction of Fatubuikaren. Villagers informed them that the enemy, wearing military uniforms and red scarves around their necks, were already in the village of Megir, to the west. On 23 November, José Lino led his platoon to Megir but came under fire from armored vehicles, so was forced to retreat to the village of Aidaba Leten, then back to the town of Atabae. The next day they hiked to higher ground, but again 
came under attack, losing two men. On 25 November, they came so close to an Indonesian company operating with Timorese "partisans" that José Lino could see that one of the partisans was his relative, Manuel Maia. Manuel yelled out that they would seize the entire Loes River valley by 24 December. José Lino shouted back that the Indonesians would have a hard time if they tried to enter the valley. After withstanding two days of heavy rain with nothing to eat, José Lino and his men crossed back over the Loes River and he returned to his wife and home in Guico.

War was coming. In a desperate effort to appeal for international support, on 28 November Fretilin held a modest ceremony in Dili at which the party president Francisco Xavier do Amaral read the one sentence proclamation of independence: "Expressing the highest aspirations of the people of Eat Timor and to safeguard the most legitimate interests of national sovereignty, the Central Committee of the Revolutionary Front for an Independent East Timor-Fretilin-decrees by proclamation, unilaterally, the independence of East Timor, from oo.oo hours today, declaring the state of the Democratic Republic of East Timor, anti-colonialist and anti-imperialist." ${ }^{30}$ Word of the proclamation filtered back to Maubara, but there was nothing anyone could do but await the inevitable invasion.

\section{Maubara Invaded}

The Indonesian military (Angkatan Bersenjata Republik Indonesia, ABRI) launched its full-scale invasion of Portuguese Timor at dawn on 7 December. Air Force planes dropped paratroopers over Dili and naval vessels disgorged marines onto the beaches to the west of town. The invasion was poorly planned and badly executed, however, allowing Fretilin leaders and many residents time to retreat south to the mountains of Aileu. Indonesian military strategy was to fan out from Dili along the major roads, with initial emphasis placed on the north coast from Dili to Manatuto, Baucau and on to Lospalos, followed by advances along the smaller arteries into the interior in order to meet up with troops that landed at points on the south coast.

The Indonesian military temporarily overlooked Liquica district, in part because Fretilin leaders had retreated from Dili southward into the interior and ABRI commanders did not believe that Fretilin had significant 
forces in Liquica, in part too because ABRI forces coming overland from the west were stopped at the Loes River, which was swollen from heavy rains. ${ }^{31}$ This meant that in December 1975 and early 1976 Falintil forces could operate freely in the Loes River bed connecting Liquica to Ermera and fend off Indonesian forces to the west in Atabae. Hermenegildo Alves, a high-ranking Falintil officer who had served in the Portuguese colonial army, took command of the Fronteira Norte (Northern Frontier) region, which covered Liquica, Ermera, and parts of Bobonaro. ${ }^{32}$ Formal lines of command were lax, however, and with suspicions high there were abuses. Having remained in Maubara with his militia, Ramahana set up camp in the Goncalves plantation in Bella Vista, to the east of the Sanches homestead. One day José Lino heard that Ramahana had murdered a man from Caiva hamlet. José Lino asked commander Alves about this, and was told that it was true: villagers had accused the man of being a spy, so Ramahana killed him. ${ }^{33}$

In June 1976 Helio "Mau Kruma" Pina arrived in Fatubessi to serve as the political commissioner for Fronteira Norte. His route there had been circuitous. After fleeing Dili in December with other members of the Fretilin Central Committee, he and his companions had traveled with their UDT and Apodeti prisoners south to Same, in Manufahi district. From there Mau Kruma and his father, who was still being held prisoner, traveled east to Lacluta and then in May 1976 Mau Kruma backtracked to Soibada to attend the first postinvasion Fretilin Central Committee (CCF) meeting. ${ }^{34}$ The CCF appointed a number of leading figures to serve in or near their home areas, and so in May Mau Kruma and Fera Lafaek, another CCF member, made their way to Fatubessi, which served as headquarters for Fronteira Norte. Mau Kruma first set up base in Faulara, in the upper reaches of the Loes Valley, where he married Norberta Martins, a cousin of Fretilin Prime Minister Nicolau Lobato. ${ }^{35}$ The couple subsequently moved to the higher ground of Fatubessi, in Ermera, where Mau Kruma became well known for his total devotion to directing the war effort.

Conflict quickly erupted in Fatubessi between the more radical Fretilin political leaders and the more cautious Falintil officers who had once served in the Portuguese colonial military. The division was sufficiently serious that Mau Kruma demoted a sergeant major named José da Silva and other junior officers who he believed to be insufficiently 
revolutionary. In response, his adversaries formed a sect called Maromak Fatubessi (God of Fatubessi), and are alleged to have attempted to stage an internal coup. Learning of the plot, Mau Kruma made counterarrests and eventually ordered the execution of José da Silva. ${ }^{36}$ This was by no means an isolated incident. A combination of political inexperience and the horrors of the Indonesian offensive resulted in similar struggles elsewhere, most famously in the Quelicai, Uatulari, and Iliomar regions in the eastern districts.

The Indonesian military finally launched an offensive against the Fretilin stronghold of Liquica in mid-May I976. The Falintil commander in Liquica subdistrict, Evaristo Alves, was killed in combat on 26 May. A few days later José Lino and nine men on horseback traversed the Maubara ridge and descended to where they could see the small, brackish lake near the coastal road. With their commander dead, Falintil troops had fled and were nowhere to be seen. At two o'clock that afternoon José Lino saw Indonesian troops advancing along the coastal road into Vatuvou. The men fired a few shots, more as a warning than in the hope of actual hitting the enemy, then headed for higher ground, following the mountain ridge to Guguleur and from there descending the southern flank of Mount Maubara to their base in the Loes Valley. ${ }^{37}$

On the morning of 2 June, Indonesian naval warships fired on Maubara and then troops from the 403rd Indonesian Army Battalion entered the town unchallenged. ${ }^{38}$ As was the case in I94I when Australian troops reached Maubara, almost all of the indigenous population had already fled up the mountain, leaving only the Hakka merchants and their families in the town. With advance warning that Indonesian troops were coming, most of the Hakka families had gathered in one house, with the door closed and windows shuttered. The Indonesian soldiers knocked on the door and ordered everyone to come outside. The commander asked for two men by name. "They've gone to Australia," was the response. The soldiers then demanded that the frightened men and women give them gold. ${ }^{39}$ The Hakka families said they did not have any gold, but offered food and water. Angered that they had not been given valuables, the soldiers herded the families the short distance down the main road to the old Dutch fort, where the men were separated from the women. ${ }^{40}$ 
One of the older Hakka women who could speak Indonesian told the troops that some of their relatives were hiding in the dry riverbed close to the Chinese cemetery south of the town. The group consisted of two adult men-Jap Kong Su (alias Jap A Leng) and Lay In Fa, both in their fortiesand about two dozen children. The next day Indonesian soldiers escorted the woman to the dry riverbed, where she called for the group to return to town. The two men led the children out of their hiding place and back to town, where they were told to join the Hakka women and girls in the open field in front of the subdistrict office. The other Hakka men, who had been separated from their families the day before, were nowhere to be seen. Lay In Fa asked what had happened and was told that soldiers had taken the men away, perhaps to serve as porters (tenaga bantuan operasi, TBO) for the Indonesian Army. Sometime later, a young Timorese man serving with the 403rd Battalion told Jap Kong Su and Lay In Fa that the soldiers had shot all of the Hakka men, but did not know exactly where. In fact, the two men and their relatives had been bothered by a foul smell but had not dared to ask the soldiers where it was coming from or what had happened to their relatives. Perhaps also aware of the smell, the battalion commander ordered his men to take the corpses to the top of a small hill called Leoborai Rau and burn them. ${ }^{41}$

About a year later, while taking an afternoon nap, Jap Kong Su had a dream in which one of his missing relatives told him, "Uncle, we're alright now, we're living in a nice place. But a few of our people are still in the sea." While Jap Kong Su was napping, his houseboy had gone to the home of Nheu Siu Kim and the two walked down to the beach to look for fish. What they saw shocked them: the receding tide had partially uncovered human bones and a pair of pants. Afraid, they returned to town and the houseboy told Jap Kong Su what they had seen. Jap Kong Su rushed to see Nheu Siu Kim and, ignoring the five o'clock curfew, the two men walked down to the beach to take another look. They pulled the pants leg out of the sand, wrapped it up, and returned home distraught. Seeing one of the older Hakka women, Jap Kong Siu was overcome with grief and broke into tears. An Indonesian soldier asked why he was crying. Jap Kong Siu explained the discovery of his relative's corpse on the beach. The soldier told him to stop crying and said he would report to the subdistrict commander. 
The commander summoned all of the civilian security personnel and the platoon commander and told them to go down to the beach. He wanted proof before deciding what to do. The men soon returned and said that there were indeed bones and a pair of pants partially buried in the sand. The next morning, the commander, his men, and various civilians living in town all went back to the beach. "If you all cry like Jap," the commander warned, "we won't be able to do anything. This is a secret. We'll get in trouble if our superiors find out." The crew set about digging. The first corpse that was uncovered was Jap Kong Su's brother-in-law, Jong Kin Siun. The second was Jap Kong Su's older brother, Jap Nie Su. The third was also a brother-in-law, Nheu Pi Sian. The fourth was his in-laws' younger brother, Nheu Li Sian. The fifth was a man named Lay Fon Fa. They could be identified by their clothing and possessions. The bones and other items were carefully collected, placed in a coffin, and then buried in the corner of the cemetery across the street from the old church. ${ }^{42}$

The massacre of Chinese men in town marked the onset of a massive new wave of violence in Maubara. After seizing the town of Maubara in June 1976, the Indonesian military deployed troops to secure the rutted but strategically critical one-lane road that led over Mount Maubara to the Loes Valley and then reconnected with the coastal road in Atabae. These units quickly reached Maubaralissa, and from there continued to scout the remainder of the ridge that leads to Guguleur and the summit of Mount Maubara. The Indonesian troops encountered few people, but burned the abandoned wood and palm dwellings. In Lissalara, at the peak of the mountain, they set ablaze the Doutel clan's sacred house (uma lulik). ${ }^{43}$ Many of the family heirlooms, including the royal patents received from the Portuguese and the VOC in the eighteenth century, were burned. But when they had fled into the forests senior family members had taken other items-including the cane of office and a pair of male and female sculptures-with them for safekeeping. ${ }^{44}$ Like many other villagers in Maubara, the extended Doutel family survived in the forests on corn and cassava from their fields, wild plants, and animals they could hunt. With Indonesian troops now scouring the mountain, displacement had turned into a game of cat and mouse, but with fewer and fewer places to hide and even greater pressures for food and shelter. 


\section{The Dark Years in Between}

Despite the fact that Fretilin forces maintained base areas and put up fierce resistance to the invaders, Indonesian President Suharto pressed ahead with plans for the territory. In July I976, a number of UDT and Apodeti leaders were flown to Jakarta where they presented a carefully choreographed "petition" to Suharto, who on I7 July signed Law 7/76 formally integrating East Timor into the Republic of Indonesia. A provincial government was quickly established. In order to present the appearance of complicity, the Indonesian government appointed East Timorese to executive positions and seats in the newly created provincial and district legislatures. Apodeti received the largest number of positions, with a smaller number of posts going to individuals from UDT. Liurai Gaspar Nunes of Maubara, who had supported UDT, was appointed speaker of the provincial legislature.

In Liquica district little-known individuals who had joined Apodeti received postings in the new administration. The first district administrator (bupati) of Liquica district was Francisco dos Santos Ribeiro and the first subdistrict head (camat) of Maubara was Leoneto Martins-both of whom were from the hamlet of Caicasa, in Guguleur, and had joined Apodeti in $1975 .{ }^{45}$ The Indonesian authorities also appointed new village heads throughout Maubara, and it appears that an effort was made to select individuals from the old noble families to fill these positions. In Guguleur, the first Indonesian-era village head was a man named Mau Boesa, who was the son of Mau Kura and a seventh-generation descendant of D. Francisco Xavier. In Vatuvou, similarly, the first Indonesian-era village head was Lucana (baptized Lucas Correia), who was the son of Sada Bessi and the grandson of Dom Carlos. ${ }^{46}$

Meanwhile, deep in the coffee plantations, now overgrown from lack of care and the primary forests beyond, the resistance held out. Mau Kruma was the most senior civilian leader in Fronteira Norte, and although based in Fatubessi, Ermera, he maintained regular communication with the resistance in Maubara and made periodic trips down the Loes Valley to organize, inspect troops, and issue instructions. In Maubara itself, aristocratic families and the mestizo planter families from the south side of the mountain-the Brites ${ }^{47}$ Chaves, ${ }^{48}$ and the intermarried Carrion and Lobo families ${ }^{49}$-played a leading role in the resistance. In 
contrast, the mestizo families on the north side of the mountain-the Sanches and Goncalves families-had overwhelmingly supported UDT and played no role in Fretilin or the armed resistance against the Indonesian military.

Despite the Indonesian military's initial focus on the western districts and the 1976 seizure of the coastal towns of Aipello, Liquica, and Maubara, the Loes Valley remained under Fretilin control throughout I976 and I977. Thanks to rice paddies and irrigation constructed by the Japanese military in I943-I944, the valley produced enough food to support the resistance, and some sources claim that Fretilin envoys from the eastern sector even came to the region to collect rice and corn..$^{50}$ In November 1977, Fretilin leaders held a party in the valley to celebrate the second anniversary of the declaration of East Timor's independence. Mau Kruma, escorted by a thirty-two-man platoon, attended the festivities. Several months later, Mau Kruma summoned José Lino dos Reis to Fatubessi and asked José Lino to serve as his personal bodyguard. The pair traveled extensively together, visiting Railaco, Maubara, and Hatolia, where they held weeklong meetings with local resistance forces. Mau Kruma also received visits from units far and wide, deciding where troops should operate and providing official letters for local Fretilin delegations to take back to their home areas. ${ }^{51}$

By 1978, however, Indonesian military operations were wearing down the resistance and civilians were suffering from sickness, injuries, and hunger. With Indonesian troops conducting sweeps through the coffee plantations, villagers who remained in the forests of Maubara were finally forced to surrender. When Mau Kuru finally returned to the destroyed village he brought with him the family's cane of office and the sculptures of a male and a female ancestor that had been kept hidden in the forests. These items were soon seized by local collaborators working for the Indonesian military. No one knows for certain what happened to the scepter and sculptures, but there is suspicion that Leoneto Martins, the Doutel's distant relative from Caicasa, now working for the occupying regime, was behind the confiscation because he coveted objects associated with traditional authority. ${ }^{52}$ For the Doutels a return home was doubly impossible. ${ }^{53}$ Not only had their homes been destroyed or fallen into decay during the period spent on the run in the forests, but they and thousands of other 
villagers were shunted into temporary camps under military guard, and from there many were forcibly relocated to holding settlements near Atambua, in Indonesian West Timor. ${ }^{54}$

The Indonesian military encirclement of Fatubessi tightened further in January 1979. Left with few options, long-standing divisions within the remaining Fretilin force led to open conflict. As political commissar, Mau Kruma insisted on continuing the resistance, even if that meant death. The highest ranking Falintil commander in Fatubessi, Filomeno Paixão de Jesus, argued instead for surrender. Accounts differ widely, but it is commonly held that Paixão de Jesus took three hundred troops and civilians and a large number of weapons with him when he surrendered..$^{55}$ With Indonesian troops closing in on Fatubessi, Mau Kruma, his wife Norberta, and their remaining men fled east to Hatolia. Ill and unable to keep up with his platoon, Mau Kruma ordered his men to escape while he, his wife, and their baby son hid in a cave. Indonesian soldiers had just passed the cave when the baby started crying, and the soldiers returned and ordered the couple to come out. Mau Kruma's wife shot one soldier, at which point his colleagues opened fire, hitting Mau Kruma in the center of his forehead and Norberta in the sternum and ribs, killing both instantly. Miraculously, the baby, who was only grazed on the knee by a bullet, survived and was taken to Dili. ${ }^{56}$

The war years had taken an enormous toll in terms of hunger, sickness, and loss of life. The I963 Portuguese census counted I3,645 people in Maubara, while in 1980 the first Indonesian census found only II,45Oa I6 percent decrease. ${ }^{57}$ The occupation also profoundly reshaped Maubara's elites. The landowning mestizo families who had dominated political life during the last decades of Portuguese rule were displaced from their plantations. While the leading UDT families on the north side of the mountain lost family members during the party conflict of 1975 or at the hands of their captors in the mountains, the pro-Fretilin families on the backside of the mountain lost much of the younger generation that had taken up leadership roles in the resistance. By the late I970s, surviving family members from both sides drifted to Dili, where they resided with relatives. For the ethnic Chinese, a similar process of displacement was at work, with most families driven out of Maubara to Dili, and those who could emigrating to Macau or Australia. ${ }^{58}$ 
The fate of the leading indigenous families of Maubara varied greatly. Gaspar Nunes, from the village of Vaviquinia, first served as speaker of the provincial legislature and then was appointed as one of the regional representatives from the province of Timor Timur (East Timor) in the national People's Consultative Assembly in Jakarta. ${ }^{59}$ Others, including the Doutels of Guguleur, the descendants of Dom Carlos of Vatuvou, and the grandchildren of Mauvili from Maubaralissa had nowhere to go but back to their home hamlets, or at least to those locations specified by the military for human habitation.

Throughout the I980s the people of Maubara did what they could to get on with their lives. Despite the struggle to feed families, matters were made easier in one respect: after the fall of Fatubessi, Fretilin no longer had a presence in the region, so that the district and subdistrict military commands had little reason to be overly suspicious of the villagers, and hence direct harassment was minimal compared to that experienced in the eastern and south-central districts during the same period. In about I985, Mau Boesa (who was now one of the oldest members of the Doutel family) and Mau Kuru oversaw construction of a new sacred house in Lissalara. ${ }^{60}$ The remaining family heirlooms-a small cannon, the remains of several thin metal drums, shards from old Dutch ceramics, and so onwere stored there, but a few smaller items were hidden away in the family's homes.

Informants in Maubara show little interest in discussing events or experiences during the I980s, but many agree that 1990 marked a turning point. The starting point in these narratives is the murder of two individuals accused of being witches (suanggi). ${ }^{61}$ It is all too easy to assume that the Indonesian military was responsible for these killings, or to suggest that the accusations were no more than covers for everyday revenge killings resulting from a spurned lover or land dispute. But similar accusations of sorcery and killings had emerged elsewhere in East Timor in the late I970s and early I980s after the rural population had surrendered, bringing bitter political rivals face to face and fueling competing accusations of ties to the resistance or collaboration with the occupiers. ${ }^{62}$ There are several possible explanations for the sudden appearance of suanggi cases in Maubara.

The first of these involves an apparition. According to José Lino dos Reis, one night a man named Floriano, who lived in a simple house in 
the midst of a coffee plantation, heard a strange noise outside his house. Peering into the darkness, he could faintly make out the shape of a man with very long hair walking toward him. As the man came closer, Floriano could see that it was José Cirilio Nunes, the son of former liurai José Nunes. Known by the nom de guerre Mau Brani, he was a flamboyant (and some say reckless) Falintil commander in the eastern districts during the I970s but is generally believed to have been killed during the fall of the Fretilin base on Mount Matebian in late I978. Floriano was frightened by the apparition, thinking Falintil guerrillas were back in the area. ${ }^{63}$ This incident may not have been entirely random, for in I990, Miguel Sanches of Maubaralissa (no relation to the mestizo Sanches family of Lauvei) heard that Falintil was reestablishing a presence in the western districts and had made an appearance in Liquica district. In great secrecy, Miguel and several friends scouted through the forests and down into the Loes River valley in search of Falintil patrols, but failed to find signs of the resistance. ${ }^{64}$ The rumors prompted Felix da Costa to begin organizing a clandestine network to gather intelligence and provide assistance to the guerrillas. ${ }^{65}$ It is possible, therefore, that as word spread of the Falintil presence and local initiatives to build a clandestine organization, the military sought to quell these activities and discourage others by spreading fear and demonstrating that joining the resistance could have fatal consequences. A second possibility is that the accusations of witchcraft and the murders stemmed from increasing tensions both within and between the leading indigenous families of Maubara. For in the late I980s, as occupation became a fact of life, competition arose over recognition and positions in the Indonesian regime. In I989, for example, several rather distant members of the Doutel family who lived in Vatuboro and Caicasa set about collecting information about the family history, apparently in an effort to justify their own claims to local prominence. ${ }^{66}$

The rumors were in fact true: Falintil had returned to the western districts. ${ }^{67}$ After spending seven months in detention for his proindependence activities, Felix da Costa was released and immediately set about building a new clandestine network in Maubara. A breakthrough came in 1994 when da Costa and Miguel Sanches met with Falintil commander Konis Santana and thirty armed guerrillas at Saré, in the Loes River valley ${ }^{68}$ Commander Konis instructed them to spread the word among their families and friends 
that Falintil was operating in the area and that villagers should not to be afraid. He asked Felix and Miguel to organize those who supported the struggle for independence to provide food, flashlights, and batteries to the guerrillas. ${ }^{69}$ As the Falintil presence spread in the western regions, so too did the clandestine civilian networks. In January I995, Falintil staged an armed attack on Indonesian troops in the village of Leotela, in Liquica. The following day, the Liquica District Military Command, operating in concert with the Army's much-feared Special Forces Command (Kopassus), carried out a retaliatory attack on proindependence supporters in Gariana hamlet, in Vatuvou village, executing six individuals. ${ }^{70}$

Competition between elite families in Maubara intensified during the early I990s. In Maubaralissa, Fernando da Silva Luis, a descendant of Mauvili, began constructing a new sacred house to compete with the Doutels, who had rebuilt their uma lulik a decade earlier. ${ }^{71}$ At about the same time, conflict erupted over the Sanches coffee plantation in Lautekas. Several dozen families from Vatumori claimed the land had been stolen from their ancestors and demanded that the Sanches family return it. ${ }^{72}$ The clandestine group led by Felix and Miguel recognized that traditional authority, even if now powerless in real terms, could be either a detriment or an asset in their struggle against the foreign occupation. They are alleged to have initiated a campaign of terror against Fernando da Silva Luis, the grandson of Mauvili who in 1975 had supported UDT, by throwing stones at his house in the middle of the night. For Fernando, the source of the terror would have been unclear: it could have been the work of those who supported the resistance in an effort to shift his allegiance away from the Indonesian regime, or it could have been an effort by the Indonesian Army's Kopassus to discourage him and others from joining the resistance. Luis eventually met with the clandestine leaders responsible for the terror and agreed to lend his support to their cause while keeping up the public charade of cooperating with the Indonesian military. ${ }^{73}$

Just as support for the resistance politicized Maubara from below, regime politics did so from above. In 1995, the Indonesian appointed district-level legislatures held elections for the position of district administrator (bupati). In Maubara, President Suharto's son-in-law, Colonel Prabowo Subianto, backed Leoneto Martins, who won sixteen of the twenty votes and was appointed district administrator of Liquica. ${ }^{74}$ Soon thereafter 
Domingos Boavida was appointed interim subdistrict administrator of Maubara. Together, Martins and Boavida oversaw the appointment of new village heads, including Fernando da Silva Luis in Maubaralissa, Alcino Goncalves (a relative of Leoneto Martins) in Guguleur, José Lino dos Reis (a descendant of Buru Bara) in Guico, and Victor da Silva Lobo (a descendant of the old dato family) in Lissadilla. ${ }^{75}$ It appears, therefore, that the Indonesian authorities and their local henchmen were appointing individuals with claims to traditional authority; and these individuals used this recognition to amplify personal claims, intensify long-standing rivalries, and at times lend covert support to the resistance. ${ }^{76}$

As district administrator, Martins viewed the populace in the starkest possible terms-those who supported integration with Indonesia and those who remained committed to independence. He recruited the former into the local military and civil service, and he made life as difficult as possible for the latter. He used the resources of office to begin recruiting young men to provide the muscle to back his rule and serve as informants for the Army Special Forces Command. Martins also set his eyes on personal gain and aggrandizement, with the Sanches coffee plantation in Lautekas a plum prize. He sent goons to pressure the family to sell, without success. To increase his leverage he charged that Falintil was using the deep forest in and around the plantation as a hiding place, and convinced the Indonesian military to begin construction of a road from the Sanches family home through the plantation to Guico on the south side of the mountain. Ostensibly done in the name of development, the real purpose was to facilitate military patrols and place further pressure on the Sanches family to relinquish their plantation. ${ }^{77}$ The road project was eventually discontinued, however, and Leoneto Martins soon became distracted by other issues and conquests.

\section{Conclusion}

The years between I975 and I998 in Maubara were a time of terrible violence. The Carnation Revolution in distant Lisbon had produced a brief period of euphoria in which the people of the colony could openly organize and stake out political positions. All too quickly, however, this gave way to seven weeks in which the newly formed political parties furiously 
arrested and at times killed fellow East Timorese in the name of a nation and state that was still a novel idea for many. The small-scale struggles between the political parties in Timor together with the continental grinding of Cold War security fears and economic interests set the stage for the horrors of the Indonesian invasion and occupation: displacement into the mountains, sickness and death, surrender and forced resettlement, and the slow return to places of origin to eke out a subsistence living under the surveillance and harassment of the Indonesian occupation. Once crushed in Maubara and much of the west, the resistance slowly rebuilt itself in the western districts, providing a glimmer of hope for some and a threat to newfound privilege and authority for others.

What this long period of violence meant to the people of Maubara varied greatly, for meaning was constructed out of a combination of oral traditions and long-standing local rivalries, contested notions of the nation, the experience of the occupation, and over time the hope of international intervention. These four levels could be felt or appealed to individually, but most commonly in combination, yielding any number of potential accounts of the present. The last Portuguese-era liurai, Gaspar Nunes, quickly and readily accommodated himself to the new regime while his son joined the resistance and was lost in combat. In Maubaralissa, Mauvili's descendants had supported UDT, suffered at the hands of Fretilin, and by the late ig8os sought to reconstruct and celebrate their ancestors, lineage, and cultural practices. Just down the road, neighbors descended from the autochthonous houses of Ikolau and Kaisave drew on the story of the Loro Liurai to construct arguments about popular sovereignty that could be applied to the struggle for self-determination. Elites in Guguleur were sharply divided as well. The Doutels opposed the occupation but did not make any serious attempt to claim or assert local leadership in the resistance, while in Caicasa their distant relative Leoneto Martins embraced collaboration and emerged in the rg9os as an ambitious local boss and a minor puppet of the Indonesian military. For all history remained very much alive. 


\section{Serious Crimes and the Politics of the Past, 1999-2012}

$\mathrm{O}^{2}$ ver the course of three centuries Maubara went from being an autonomous micropolity and port in long-distance networks of maritime trade to an enthusiastic vassal of the Dutch East India Company, then from a reluctant and rebellious center of coffee cultivation in the far-flung Portuguese Empire to a largely forgotten subdistrict under the illegal Indonesian occupation. This progression of subordination to larger, more powerful centers was punctuated by recurrent mass violence and the institutionalization of coercion. Viewed in these terms, the violence committed by the Indonesian military and its civilian paramilitaries in 1999 appears as a tragic but all-too-predictable story of continuity. But the people of Maubara did not suffer entirely in vain. The combination of Indonesia's own long-overdue democratic opening and the Habibie government's blatant disregard for its obligation to maintain security during the UN-sponsored referendum on the future of the territory finally brought the suffering of the East Timorese people to the world's attention and consolidated support for their cause. This ensured that the results of the referendum in 1999 were honored, the territory liberated, and the independence first declared in I975 was finally achieved. There was, at least for a time, even the promise that justice would be done to those who had violated international law.

The terrible violence committed by the Indonesian military and militias in 1999 has become to the study of Timor what a coda is to a symphony: summation of that which has come before and completion. This has had two related effects on scholarly approaches. On the one 
hand, scholars have treated the violence committed by the Indonesian military and pro-Jakarta paramilitaries in I999 as the final chapter in the long struggle against foreign occupation. There is now a significant body of scholarship documenting human rights violations, reexamining the twenty-four-year struggle for independence, and assessing the successes and shortcomings of the international involvement in resolving a protracted conflict. In this view, the events of I999 mark an endpoint. On the other hand, depicting the violence before and after the popular consultation as an endpoint also serves to present I999 as marking the start of something entirely new. The now numerous studies on the United Nations missions in East Timor, the building of state institutions, and postconflict development all invariably include a short section on historical background, but the dominant narrative strategy of practitioners and scholars alike has been to treat independent Timor-Leste as a "blank slate." Consciously or not, this has often led to teleological assumptions about the irrationality of all that came before and the desirability of plans formulated and implemented by the UN, international agencies, and enlightened East Timorese politicians.

In contrast to the conventional macro-level view and unproblematic periodization of "before" and "after" the I999 referendum, a microhistorical approach to the violence in a single locality serves to foreground how local history and meaning informed and were transformed by the violence as local and national actors responded over the ensuing years to independence, reconstruction, and the new realities facing postindependence Timor-Leste. This chapter begins with an account of the Red and White Iron militia in Maubara, focusing in particular on a single murder-that of Mau Kuru. The following section narrates the involvement of the Serious Crimes Unit, established by the United Nations to investigate and document human rights violations, showing that for the people of Maubara the promise of justice was nullified by a combination of institutional incompetence and the demands of national, rather than local, interests. The third and fourth sections turn to how people in Maubara responded to the issues of reconciliation, community, and their place in the new nation. 


\section{Red and White Iron}

The young men first recruited by District Administrator Leoneto Martins in the mid-Ig9os to counter the growing clandestine movement formed the embryo of what became a much-feared pro-Indonesian militia that operated throughout the district of Liquica and at times in Dili, committing some of the worst atrocities of 1999. To understand the formation of the militia, the recruitment of its members, and the course of their attack, it is necessary to begin with events thousands of kilometers away in Jakarta.

During the first months of 1998, the rising tide of protest in Indonesiaframed sequentially in terms of the region-wide economic crisis, President Suharto's last-ditch appointment of a crony-packed cabinet, and finally a mass movement demanding removal of the dictator and democratizationprovided the political opening the East Timorese independence movement had long awaited. With Indonesian eyes squarely focused on Suharto's resignation in May and the country's rocky political transition, East Timorese rushed to exploit the weakness and uncertainty in Jakarta. Resistance leaders in East Timor, in prison in Jakarta, and in the overseas Diaspora issued new calls for independence, while students and activists on the ground in Dili organized free speech forums in towns and villages. This outpouring of political defiance and renewed international attention to the fate of the East Timorese people was sufficiently serious that in September 1998 the Indonesian minister of defense announced troop withdrawals from the territory. With the central government's commitment to integration in question and large numbers of Indonesian civil servants fleeing the territory, the Indonesian Army's Special Forces Command (Kopassus) and East Timorese collaborators sought to quell the proindependence voices and offset Jakarta's apparent vacillation by mobilizing both old and new civilian militias. ${ }^{1}$

The first post-Suharto initiative to organize pro-Indonesian youth in Maubara occurred in June 1998, when Liquica District Administrator Leoneto Martins held a meeting in his home hamlet of Caicasa, a few kilometers from where the three Sanches brothers had been killed in 1975 and his distant relatives in Lissalara. During the early years of the occupation the Indonesian administration had made Caicasa the administrative seat of the village of Guguleur, and the combination of Martins's family connections and close ties to military hardliners made Caicasa fertile ground for pro-Indonesian 
recruiting. Further militia organizing occurred three months later in the Loes Valley, where the I43rd Indonesian Army battalion recruited several dozen young men to form a second militia nucleus in Vatuboro village. ${ }^{2}$ These efforts merged in November 1998 when Leoneto Martins and Maubara Subdistrict Administrator José Afat, working closely with Kopassus operatives, formally established the Red and White Iron militia (Besi Merah Putih, BMP). ${ }^{3}$ Manuel de Sousa, from the village of Vaviquinia, was appointed leader of the BMP. Although intended to represent and operate throughout the entire district of Liquica, at the outset most members came from within the subdistrict of Maubara, with Caicasa and Vatuboro serving as the central nodes of recruitment and activity. ${ }^{4}$ Individuals who joined the militia (either willingly or under threat) were usually given a small sum of money (many sources say five thousand rupiahs, about one dollar at the time), after which they received periodic enticements of money, alcohol, and drugs.

During the first two months of I999, BMP attacked a number of hamlets and villages that its leaders suspected of supporting independence and having links with Falintil. Geoffrey Robinson, who composed the most detailed assessment of the Indonesian military and militias in I999, writes, "The village of Guico in Maubara Sub-District, for example, was attacked on four separate occasions in January and February. The perpetrators of the attacks included BMP militiamen and soldiers of Battalions I43 and I44 based in nearby Caicasa and Vatuboro." 5

It was in this context of escalating militia terror that in late February I999 Mau Kuru made the three-hour walk from his home near the peak of the mountain down to the town of Maubara ${ }^{6}$ He went to visit his sister, Maria de Fatima Auria Lobo. The two were inside Auria's home talking when they heard a knock on the door. When Auria opened the door she was surprised to see that the visitors were a BMP member named Arnaldo and a second man she did not recognize. The men said that Manuel Gonçalves, a BMP leader, had asked them to summon avo (grandfather) Mau Kuru to come to Gonçalves's house for a talk. Auria told the men that Mau Kuru had already gone back up the mountain and that they were not allowed to enter her house. The two men finally gave up and left, and later that day Mau Kuru furtively made the return trip back up the steep mountain to his wife and home in Lissalara.

The following week groups of BMP militiamen extended their operations against proindependence supporters beyond the coastal settlements 
and ventured into the higher elevations of the mountain. On 8 March, three large groups of armed men-about eighty in all-converged with military precision on Mau Kuru's home in Lissalara: one group came up through the coffee plantation below Mau Kuru's home, the second arrived via the paved road from Maubaralissa, and the third came down from the summit of Mount Maubara. The men were armed with guns, machetes, and a variety of homemade weapons. Screaming threats, they surrounded Mau Kuru and his wife, Bui Krimi, in the open-air sitting area. One of the militiamen lunged forward with a spear and Mau Kuru fell, holding his side. Blood soaked his shirt. The militiamen then dragged Mau Kuru up to the paved road and hacked him to death with machetes.

Why did the BMP leaders target and kill Mau Kuru? The final report of the East Timor Commission for Reception, Truth and Reconciliation provides this summary: "A man named Mau Kuru was killed in Palistela [sic, Lissalara] Guguleus [sic, Guguleur] (Maubara, Liquica), allegedly by members of the BMP militia group, including [informants] M88 and M89, because he was accused of burning an Indonesian flag." ${ }^{7}$ In this account Mau Kuru was targeted because of his defiant political actions. In several extended interviews, however, family members insisted that Mau Kuru had done no so such thing. His widow said she does not know why the militia wanted to kill her husband, but speculated that it was over a "personal" issue. The disjunction between the "political" and purely "personal" explanations for the murder is strange and demands explanation. In fact, when pressed to explain the motivation for the murder relatives provided two alternative accounts.

The first explanation highlights Mau Kuru's identity, not his actions. Mau Kuru was murdered, some of his relatives say, because as the oldest and most senior male members of the family he and his brother were guardians of the family lore, sacred items, and hamlet affairs. It was on this basis that they had forbidden residents of Lissalara from joining the BMP militia and openly stated that the militia would not be allowed to enter the hamlet. This account positions the murder within a national narrative of resistance, but it falls well short of the claim reported to the East Timor Commission for Reception, Truth and Reconciliation that Mau Kuru had defiantly burned an Indonesian flag. The second account provided by relatives never mentions resistance to Indonesian rule, and instead emphasizes personal reasons 
Mau Kuru decided to make the trek down from Lissalara to Maubara town a week before he was murdered. Sometime in late February, some relatives say, Mau Kuru heard that the BMP leaders wanted to kill him, so he went to Maubara town to ask the subdistrict administrator, José Afat, if it this was true and perhaps request protection. Other relatives immediately objected that this does not make sense: Mau Kuru had no reason to trust the subdistrict administrator and every reason to assume that the BMP leaders did in fact want to kill him. Instead, these relatives argue Mau Kuru went to town because he wanted to hide family heirlooms at his sister's house.

Over the centuries, the family had acquired a wide variety of items, many of which were sacred and others related to the family's status as traditional rulers. Among these were Chinese ceramics, documents from the VOC, canes of office, flags, metal gongs, small canons, bronze drums, and so forth. Some of these items had been lost in earlier episodes of violence, while othersincluding two small cannons, shards of pottery, and others-were damaged and lay unkempt beneath the sacred house reconstructed in the mid-I980s. But the family had carefully hidden a few small items, and it was these that Mau Kuru had taken to his sister's house for safekeeping. They included a triple-stranded necklace of coral beads (mortel) and gold filigree, a silver necklace, and a seven-centimeter decorative silver disk (belak). No one knows the origin of these items, but it is likely that they were obtained during Maubara's heyday of trade, either from the Portuguese in the early eighteenth century or from the Dutch East India Company later in the century.

So who wanted these items? And why? Bui Krimi, who initially had said she did not know why her husband was murdered, suggested that their distant relative District Administrator Leoneto Martins wanted the items in order to bolster his administrative power with the trappings of traditional authority, and perhaps also to further his claims to the Doutel family's land. But Bui Krimi's nephew Fortunato Soares disagreed with this assessment. He suggested that Manuel Gonçalves, the militia leader who had sent the messengers to Auria's house in Maubara, and his older brother Alcino, who had once served as the head of Guguleur village, wanted the items to support their rival claims to seniority within the extended Doutel clan. ${ }^{8}$ After a long discussion about possible scenarios, Bui Krimi, Fortunato, and other relatives acknowledged that they did not know the exact motivation behind the murder of Mau Kuru. What their accounts highlight 
is that the "national" issue of East Timorese independence provided a context in which local claims and personal motivations were amplified and within which Mau Kuru was singled out for murder.

The killing of Mau Kuru-the first murder in Maubara in I999signaled a distinct shift from intimidation to the use of lethal and often indiscriminate force. The situation became even more heated in midMarch when rumors spread that a BMP member had stabbed Pastor Rafael near the church in the town of Maubara. In response, proindependence villagers descended on the town, some armed with machetes and bows, leading to a scuffle during which Leoneto Martins is reported to have been injured (or at the very least hit) by a some sort of projectile. In an attempt to defuse the situation, two resistance leaders from the National Council of Timorese Resistance (Conselho Nacional de Resistência Timorense, CNRT) traveled from Dili to Maubara to speak with the district military commander about the escalating violence. While the meeting was taking place, villagers gathered in front of the building, sang the resistance anthem "Foho Ramelau," and screamed "Viva Fretilin! Viva CNRT!"9 Martins and the BMP leaders responded, in turn, with even more intimidation. In the wake of this confrontation in town, thousands of villagers fled their homes, some seeking refuge in the towns of Maubara and Liquica, and even Dili, while many more took refuge in the Faulara-Saré area in the relatively inaccessible upper reaches of the Loes River valley.

There was a further escalation in violence in the following months. In early April BMP militiamen accompanied by Indonesian police attacked villagers attending mass in the main Liquica church, slaughtering dozens of people. The following month BMP members traveled to Dili, where they attacked the home of Manuel Carrasacalão, killing at least twelve people from Liquica district who had sought refuge there..$^{10}$ Militia activity continued throughout June, July, and August, though as Robinson has shown the timing of escalation and brief periods of restraint demonstrate that the Indonesian military continued to exercise extensive control over its proxies.11

On 30 August, despite continued threats and the prospect of even worse violence, the people of East Timor bravely went to the polls to cast their votes in the referendum. The result was an overwhelming vote against Indonesia's offer of broad autonomy (and hence in favor of independence), meaning the terrible twenty-four-year Indonesian occupation would finally 
end. But it was not yet over. When the results were announced, the Indonesian military and its district-level militias went on a violent rampage, killing over one thousand proindependence supporters, ${ }^{12}$ destroying basic infrastructure and burning government buildings and homes, killing livestock, and forcibly moving hundreds of thousands of people across the border into Indonesian West Timor. Tense negotiations among the UN, Portugal, and the Habibie government in Jakarta during the month of September finally resulted in a formal decision by the Indonesian Parliament to relinquish its claim to the territory and a promise that all Indonesian military personnel would be withdrawn. Soon thereafter, the United Nations set in motion plans for the arrival of an Australian-led International Force for East Timor (Interfet), and soon after that for the establishment of a UN mission. The United Nations Transitional Administration in East Timor (UNTAET) was charged with restoring order, building state structures, and preparing the long-suffering nation and the nascent state for independence. The story of UNTAET's reign of two and a half years has been told elsewhere in great detail, so it need not detain us here..$^{13}$

\section{The Serious Crimes Unit}

The referendum brought an end to the long occupation, but it had come at a high cost and there were immediate calls from within the United Nations, from concerned governments, from the activist community, and from a handful of East Timorese leaders for the pursuit of justice.

Almost as soon as they entered the territory in late 1999, members of the Interfet peacekeeping mission began to conduct preliminary investigations into the anti-independence violence. This primarily involved the recovery of the bodies of individuals who had been murdered. Remains were to be buried in a specially designated cemetery in Kakaulidun, Dili. Sometime in early 2000 an investigator assigned to Liquica district heard about the murder of Mau Kuru in Maubara and a team was sent to the mountaintop. After explaining to the family that a full investigation had to be conducted and receiving the family's approval, the team exhumed the grave and removed Mau Kuru's headless body. ${ }^{14}$ About a month after the exhumation, the chief of Lissalara hamlet, who was married to Mau Kuru's niece, had a dream in which he saw Mau Kuru's missing head lying in one of the family's fields. 
The next day he and several relatives launched a search and found the skull. Rather than bury it in the now empty grave or travel to Dili to turn it over to the Interfet investigative team, the family decided to store the skull at the home of a relative who lives closer to the peak of the mountain. ${ }^{15}$

The preliminary investigative work done by Interfet staff was soon taken over by a new institution, with significantly more authority and, over time, expertise. One component of the UN mission was the establishment in June 2000 of the Serious Crimes Unit (SCU), mandated to investigate human rights abuses committed in I999, with indictments to be forwarded to the Special Panels for Serious Crimes, also established by the UN, under the Dili District Court. ${ }^{16}$ Staffing and basic logistics took time, and it was not until 20OI that SCU was ready to begin field operations. Even then, there was a severe lack of resources (vehicles, cameras, office computers, paper, etc.) and the unit suffered from what one staff member termed "a complete lack of management." Nevertheless, an investigator had been assigned to each district, so at least in theory someone was on Mau Kuru's case.

Back in Lissalara, however, more than a year went by and the family had not heard a word about the course of the investigation. So one day Fortunato Soares, Mau Kuru's nephew, went to the SCU office in Dili to ask about the body. The investigator who had first been given responsibility for cases in Maubara was still there (turnover of international staff in SCU was extremely high), but he said he would have to check the records. He asked Fortunato to come back the following week. When Fortunato returned the following week, the investigator told him that Mau Kuru's remains had been exhumed by Interfet, not SCU, and that SCU had not received any records about the case. ${ }^{17}$ No records, no identification of the remains.

Where consulting the experts had failed, the family found more success through dreams. Mau Kuru's widow, Bui Krimi, repeatedly dreamed that the family must hold a ceremony to formally "bury" her husband. An older relative thought it best to wait for the remains to be returned, so attempted to "send" dreams to recall the remains to Lissalara. But to no avail. Then, one night, Bui Krimi had a dream in which Mau Kuru told her that he was in a row of boxes and his was numbered 217. So on Fortunato's next visit to the SCU office, when there was still no information about the fate of Mau Kuru's remains, Fortunato told the investigator about Bui Krimi's dream. The investigator thought that boxes in neat 
rows sounded like a cemetery, and suggested it could be the Kakaulidun cemetery established by Interfet in 200o. He instructed the cemetery caretakers to exhume grave $2 \mathrm{I} 7$ in the Interfet cemetery, but when the box was opened there was a surprise: it contained not one skeleton but the partial remains of three different bodies. Because SCU could not positively identify the remains, they did not know if Mau Kuru's remains were among them. The investigator also explained that if he gave Fortunato the wrong remains, it would not help the family and they would continue to be plagued by bad dreams.

Mau Kuru's relatives had had enough. So on yet another trip to Dili Fortunato went to the District Court to lodge a complaint and demand the return of Mau Kuru's effects so that the family could perform the final rites and lay his spirit to rest. It seems that someone at the District Court communicated Fortunato's demands to SCU, because soon after the visit the family received notification that an agreement had been reached and Mau Kuru's effects would be returned to his relatives in Lissalara. The spearhead that had pierced Mau Kuru's side was found in the office of a different investigator and returned to its proper place with the other evidence-the clothes Mau Kuru wore on the day he was murdered and his identification card-in a standard-issue white plywood box. A SCU staff member then drove the box to the top of Mount Maubara and gave it to Bui Krimi, together with forty dollars. ${ }^{18}$ As far as SCU was concerned, the case was closed.

The fate of Mau Kuru's remains illustrates the potentially tragic divergence between the promise of justice and local experience. The United Nations and the mission tasked with administering East Timor felt obliged to investigate human rights violations, and many individual staff members took the quest for accountability and justice extremely seriously. But the foreign investigators who staffed the SCU lacked local knowledge, including relevant language skills, and were faced with a bewildering number of cases. Families of victims were often torn between the goodwill toward the UN created by the success of the popular referendum, the hope for justice, and the failure to deliver concrete results. For Mau Kuru's relatives matters were further exacerbated by what appeared to be institutional incompetence, and all that remained was to fulfill cultural obligations by holding final rites. 


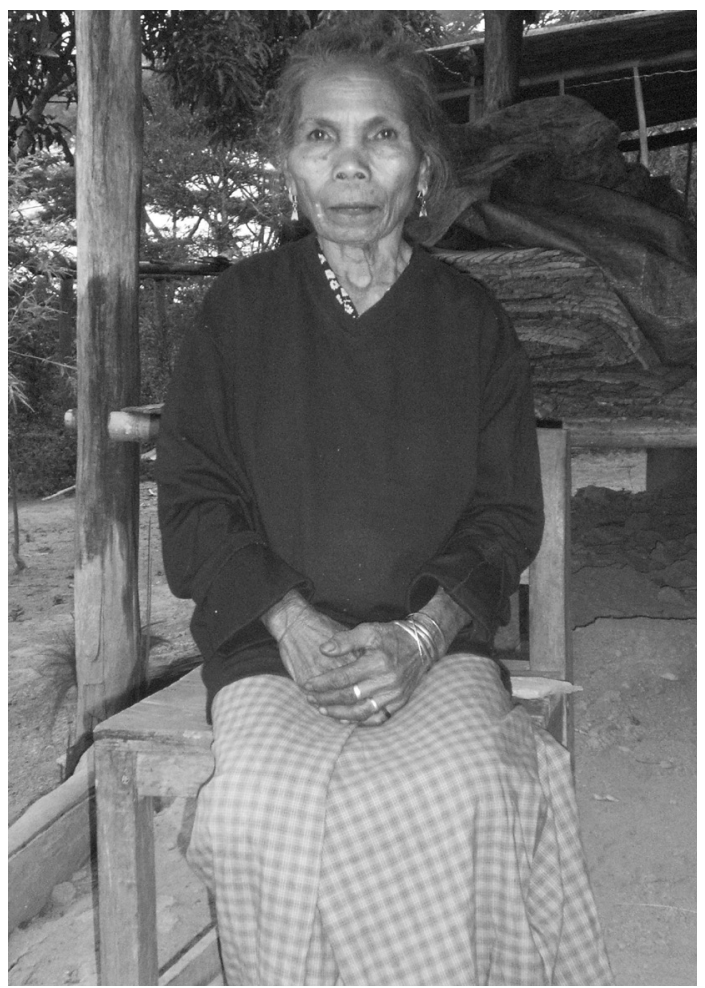

FIGURE 10 Bui Crimi, widow of Mau Kuru, 2008 (courtesy of Selma Hayati)

\section{Good Neighbors, Bad Neighbors}

For many East Timorese the hardships of 1999 and reconstruction under the United Nations mission were offset by the hopes of what independence would bring. The restoration of independence in May 2002 was a moment of pride and great joy for those who had lived through the occupation, and a time of youthful anticipation for those born during the latter part of Indonesian rule. It was also a time of concern about the fate of relatives still living in Indonesian West Timor. Would they return home or remain there, forever separated by an international border? There was also apprehension about the former militia members who slowly began to return to Timor-Leste. While many of these men first went to Dili or other towns, over time more and more returned to their native villages to eke out a livelihood within earshot of those they had once intimidated and the relatives of those they had killed. 
The new Fretilin government, recognizing both the historical importance of the flag in Timorese cultures and the desire that many people in scattered villages and hamlets had to participate in the national project, announced a plan to distribute the national flag to each suco. When the district administrator distributed the flags, each village set a date for its own flag raising ceremony. I attended the ceremony in Lissadilla, in the Loes Valley. Lissadilla was one of the early settlements that is said to have contributed a representative to serve the stranger kings from SuaiCamenassa and actively contributed to Maubute's uprisings in the late nineteenth century. The original dato lineage, the Lobos, had lost many sons in the resistance but continued to exercise a strong presence in public affairs and ritual life in the village.

Lissadilla held its flag ceremony on I2 July 2003, a little over a year after the restoration of independence. It was the dry season and the valley was parched: many trees had shed their leaves, fields were barren, and the dirt tracks were thick with dust. The ceremony began with a procession of adult men dressed in traditional finery of colorful double-woven cloth, batik headscarves, silver medallions, and feathers, many carrying swords or machetes, and all marching in a stiff, highly exaggerated imitation of Western military step to the beat of drums. There were dances and songs. A group of children paraded with homemade wooden toy guns. Then, with the full platoon of warriors standing stiffly at attention, the red, yellow, and black flag of Timor-Leste was raised on a wooden flagpole. After the solemn flag ceremony, a series of entertaining skits were performed. The first, titled "Youth and the Red and White Iron Militia," depicted the BMP terrorizing the village, the day of the referendum, the announcement of the results and exuberant cries of "Viva Timor-Leste!" The second skit, called "Falintil and the Indonesian Intelligence Task Force," depicted clandestine activists carrying baskets of provisions to the Falintil guerrillas, Indonesian military intelligence personnel roughing up the couriers and inappropriately searching the young women, and finally a Falintil ambush on the oppressors. The skits were greeted with wild cheers from the audience. Next it was time for speeches by the dignitaries in attendance. While many of the villagers drifted away, eagerly awaiting the cockfights, a lone warrior wearing a full headdress and holding a machete guarded the shadow of the flag as it imperceptibly edged away from the setting sun. The district administrator, who before her appointment had been 
a lecturer in politics at the new National University of Timor Lorosae, gave a long speech. At one point she told her audience that she was tired of seeing people in the villages perform the same old traditional songs and dances, and declared a need for them to become "modern."19 Bored by the length of the speech and now offended, more people drifted away from the stage to watch the preparations for the cockfight or simply chat in the shade.

The flag ceremonies in Lissadilla and other villages were intended to be a celebration of community-historical communities of lineage and house, the experiential bonds of the resistance, the administrative community of the village unit, and beyond that the imagined community of fellow East Timorese one had never met. But in the case of Guguleur, such assumptions about community could just as easily become the source of disputes. At the time the flags were distributed, the village head of Guguleur was a man named Luis, who had been active in the clandestine resistance during the I990s. ${ }^{20}$ Luis did not want to hold the ceremony in Caicasa on grounds that the Indonesian state had made Caicasa the seat of village government and that it had been the base of the BMP. Instead, he argued, the ceremony should be held in Lissalara, where the surviving members of the Doutel family lived and where Mau Kuru had been murdered. But the district administrator, who was not from the area, insisted that the flag ceremony be held in Caicasa. In the end, deadlock meant that the muchanticipated flag ceremony was never held in Guguleur.

Flags were just the beginning, for there was also still the problem of bad neighbors. In 2003-2004, the East Timor Commission for Reception, Truth and Reconciliation conducted a series of village-level community reconciliation processes (CRPs) throughout Maubara. ${ }^{21}$ These drew heavily on contemporary notions of "traditional practices," 22 often with the figure of the "ritual speaker" (lia nain) given a leading role. In 2003 a joint CRP was held for the villages of Guico and Lissadilla, and later that year it was the turn of Vatuboro. In 2004 CRP were held in the villages of Vatuvou, Guguleur, Maubaralissa, and finally Vaviquinia. ${ }^{23}$ The number of deponents varied, as did the results. In Vaviquinia there were only three deponents because, in the words of the subdistrict administrator at the time, "otherwise there would not have been any reconciliation." After the event, more than one hundred people-former militia members and proindependence supporters alike-worked for five days to repair four kilometers of a road. 
In Guguleur, of which the militia stronghold of Caicasa is a part, there were so many deponents that the CRP had to be held in three separate locations. The CAVR report provides a special feature on Caicasa, which describes the public questioning of a deponent regarding the murder of "an old man," not named. This was Mau Kuru.

The deponent was clearly familiar with the matter and responded angrily that he was tired of being accused of responsibility for the murder. He acknowledged that he had been present when the killing had taken place. He said that he had already given what information he had about the case to the authorities, and that he now wanted an end to the allegations against him. As more questions were directed at him, he countered by accusing one of those who questioned him of himself being an informer for the Indonesian security forces. As tempers flared, CRP staff intervened to calm the situation. ${ }^{24}$

These reconciliation processes incorporated various features that were deemed to be "traditional." So at the same event in Caicasa, lisan leaders oversaw the slaughter of several chickens. "Of the four chickens examined, one had blemished entrails, leading the traditional leaders to conclude that some of the deponents had not told the whole truth, and to proclaim that they would have to live with the consequences of this." ${ }^{25}$ In the end, villagers in Guguleur-again including both deponents and other villagers-planted thirteen hundred trees as a symbol of renewal.

A number of people in Maubara raised objections to the reconciliation process. In Maubaralissa, many villagers boycotted the event on grounds that a former militia member was working for the Truth Commission team. ${ }^{26}$ In Guguleur, Mau Kuru's relatives say that they were asked to participate in one of the reconciliation processes but protested because "serious crimes," such as the murder of Mau Kuru, had to be handled by the judicial mechanisms. ${ }^{27} \mathrm{~A}$ number of respected proindependence figures argue that whether they agree or are satisfied with the results of the community reconciliation hearings is irrelevant. ${ }^{28}$ They insist that there is no need for further action against individuals who threatened or intimidated proindependence supporters or other villagers who did not take a public stand, accepting that this sort of behavior was an understandable consequence of their political choices. But they feel strongly that those 
who committed serious crimes-the destruction of property or livestock, bodily harm, or murder-must be brought to justice.

Mau Kuru's relatives and others in Maubara might disagree about the motivation for the murder of Mau Kuru, but they all knew BMP militia who had surrounded the family home on 8 March I999 and could identify three individuals who were deemed to be "responsible" (in terms of either leadership or the actual blows that killed Mau Kuru). Armando dos Santos was convicted of crimes against humanity for his involvement in the 6 April Liquica church massacre and was eventually sentenced to fifteen years in prison. ${ }^{29}$ Mau Susar and Asuwana, the two other ringleaders in the murder of Mau Kuru, were not indicted or brought before the Special Panel in Dili, and after spending some time in Indonesian West Timor they eventually returned to their homes in Laovo hamlet, in Guguleur. Mau Susar died suddenly in 2007. Asuwana came to Lissalara in late June 2008 to participate in a traditional ceremony, much to the irritation of his victim's relatives. ${ }^{30}$

For Bui Krimi and her relatives, the pressing matter was to ensure that Mau Kuru was given the proper rites, even if there were no remains to bury. After much consultation, a date was set in mid-2005. Quite by chance, on that day I drove to Maubara to visit Mau Dua, an elderly man who lived in Lauana, on a small knoll behind the Samarapo Chapel. Mau Dua, who claimed to be I30 years old, was a direct descendant of the third of the brothers from Suai Loro given responsibility for ritual, and also had more recent family connections with the Doutel clan in Lissalara. When I arrived, Mau Dua was bent over (he had a back condition that prevented him from walking more than a few steps) on the hard-packed dirt floor where the family dried and sorted coffee beans. He said that he could not speak with me that day because he had to perform a ceremony for relatives. I asked where the ceremony was and how he was going to get there. His family did not own vehicle and none had been sent to collect him. The answer, I was told, was that a relative was going to put Mau Dua in an old wheelbarrow and push him two kilometers up the mountain road to Bui Krimi's home, just below the summit. Mau Dua quickly agreed that the mattress in the back of my old Toyota Land Cruiser looked far more comfortable than the rusty wheelbarrow, so we maneuvered him into the truck and set off.

At Bui Krimi's home, we found a number of relatives in the yard and a few sitting on wooden benches under a metal roof that covered the 
combined dining area, workspace, and garage. There were a few formalities, given the unexpected arrival of a foreigner, but there were no signs that any preparations had been made. Mau Dua was carried over to a spot on the slope beside the driveway, where a small patch of earth at the base of a flowering shrub was cleared and stones were placed in a circle. He crouched down and could be heard chanting in a low voice. A few men stood nearby watching, but most relatives remained further back by the sitting area, chatting casually. The ceremony took no more than fifteen minutes. When Mau Dua completed his task, Fortunato was eager to recount more details about the murder and his frustrations with the SCU. Relatives, including Bui Krimi, soon joined the conversation. There was no outward sense of sorrow or anger, just a desire to have their story heard.

New chapters lay ahead, of course. One of the most telling of these, which played out slowly over the course of several years, involved renewing connections with the past. Across Timor-Leste many families sought to reconstitute the physical symbols of tradition and spiritual connections with origins and ancestors. ${ }^{31}$ Some did so because of genuine pride in the past and their ancestors, some to renew ties within dispersed extended families, and others to flaunt their wealth and (real or claimed) status in the present. Construction of new uma lulik was both an expression of their place in the national narrative of place, "houses," and spirits of resistance, and thoroughly local manifestations of long-standing rivalries and feuds, claims and one-upmanship. In Vatuvou, the descendants of Dom Carlos, who had ruled briefly following the territorial transfer of 1859 , reconstituted their uma lulik first as a wooden model in a glass case kept inside a proper house built of cinderblocks and sheets of corrugated metal, then rebuilt in full scale near the family compound. In Maubaralissa, similarly, the descendants of Mauvili set about building a large new sacred house, much as Mauvili had done nearly a century and a half before after being banned from attending the inauguration of the Doutel's sacred house.

For a full decade, however, the Doutel's house King of All, Brave King made no move to rebuild the rotting wooden structure that had been erected in the early I980s, under which lay the unattended remnants of family heirlooms. 


\section{Old and New Rivalries in Electoral Politics}

It remains to consider how the past-including mythic origins, recurrent colonial violence, and resistance to occupation-informed people's responses to party politics and elections in independent Timor-Leste. In a comparative essay on elections in Southeast Asia, Benedict Anderson highlights the "Janus-face of electoralism": on the one hand, the right to vote has long been considered the signature of full citizenship, but on the other hand, elections historically have served to demobilize and domesticate political participation. ${ }^{32}$ In East Timor, resistance to the Indonesian occupation can be thought of as a perverse form of democratization-for anyone could support the cause of independence. In the wake of President Suharto's resignation in May 1998, furthermore, it was the myriad forms of popular activism-the formation of new organizations and public discussions, lobbying and demonstrations, and of course the threat of armed force-that eventually led to the agreement to hold the UN-sponsored referendum. It was this unprecedented and highly open mobilization that drove the Indonesian military to unleash the massive violence against the population before the popular consultation. Mass mobilization had indeed preceded the introduction of East Timor's own free elections.

Contrary to many popular accounts, the first elections after the restoration of independence in 2002 did not take place in the clear air of a new and perfect democratic dawn. The slate was never blank. The long history of recurrent violence had left deep legacies of solidarity as well as hostility, loyalty as well as mutual mistrust. The people of Maubara were neither ideal rational actors nor irrational dupes of tradition, patronage, and mystification. It is therefore important to consider how the violent remains of the past informed political choices during the first decade of independence. Given that independent East Timor has held two rounds of national legislative and presidential elections and two rounds of village-level elections, and given the large number of political parties and the seven different villages that comprise present-day Maubara, the following discussion seeks to highlight broad trends by focusing on particular families that once ruled over the former kingdom: the Doutels of Guguleur, the descendants of D. Carlos in Vatuvou, the descendants of D. Mauvili in Maubaralissa, and the descendants of the autochthonous houses of Ikolau and Kaisave. 
The first elections after the restoration of independence were held in 2005 for the position of village head (chefe de suco) and membership in the newly established village councils. Individuals running for office typically appealed to a combination of local and national identities. At the purely local level, some candidates presented themselves and were perceived by others as representing the continuation of colonial-era dynastic rule, while others emphasized their service in the clandestine networks that had supported the armed struggle against the Indonesian occupation. Candidates also identified with national political parties based on a combination of claims about the past, vague policy platforms, and elaborate visions of what the new East Timor should become. Party identification was significantly hardened by the fact that the first post-I999 village heads were appointees, and many had been selected precisely because of their service in the resistance and real or perceived sympathies for Fretilin.

Maubaralissa provides a clear example of how these cleavages played out in 2005. ${ }^{33}$ The incumbent village head was Miguel Sanches, who had been a prominent local clandestine activist throughout the I99os. He is descended from the brothers Opu Leki, who had fathered a son by the daughter of a Doutel ruler, and Barnado, who is said to have taped on a book to install newly arrived Portuguese governors. Miguel Sanches's interpretation of the Loro Liurai origin story is not that dynastic rule is legitimate, but rather that the people of Ikolau, Kaisave, and Raelete gave authority to the stranger kings. It is thus a story of power emanating from the people, with the fabled Loro Liurai now portrayed as elected representatives. Miguel says that he was reluctant to run for a second term as village head in 2005 (particularly because he had been accused of mismanaging the distribution of materials donated to the village for the rebuilding of homes), but relented because many people wanted him to continue in office. The second candidate was a man named Rui Manuel da Silva from Raelete. He was a direct descendant of D. Mauvili and was intent on reasserting the family's lineage and, some say, dynastic claims. The third candidate was Agusto de Jesus, who, like Miguel, had been a clandestine activist in I998 and after the I999 referendum was appointed head of Nunulete hamlet.

These local and historical claims were intertwined with party affiliation. Despite the fact that he had not been a clandestine activist, the monarchist Rui Manuel ran as the Fretilin candidate. ${ }^{34}$ Miguel Sanches, who 
had spent the occupation identifying with Fretilin, was now a member of Francisco Xavier do Amaral's ASDT party, which had claimed the legacy of "Maubere," the poor Timorese peasant, but the party's strategy was for their candidates to formally run as independents. Augusto de Jesus, whose involvement in clandestine activities had come at the tail end of the occupation, ran for office as the candidate for the Social Democratic Party (PSD), which was generally associated with former governor Mario Carrascalão and the pre-I975 mestizo elite. The outcome of the election was extremely close: Miguel Sanches narrowly won with 2I5 votes, Rui Manuel came in second with 206 votes, and Agusto de Jesus was third with I8o votes. Local claims to dynastic descendant, resistance credentials, and popular support and national identification intertwined in the other villages as well. The overall outcome of the elections in Maubara are rather surprising: while the independent Miguel Sanches won in Maubaralissa and the PSD candidate Guido Ramos won in Guguleur, Fretilin candidates prevailed in the other five villages (Vaviquinia, Vatuvou, Lissadilla, Guico, and Vatuboro) ${ }^{35}$

The national political crisis in 2006 had a dramatic impact on political allegiances and voting behavior in Maubara. What began as a relatively straightforward problem of alleged discrimination within the new national military (F-FDTL) by officers from the eastern districts against new recruits from the west resulted first in desertions, then a formal petition requesting presidential intervention, and finally demonstrations in front of the prime minister's office in Dili. The demonstration descended into a minor riot that in turn unleashed a series of armed clashes between factions within the security forces and armed civilians and came to be framed in highly polarized terms: an "authoritarian" Fretilin government versus a "democratic" opposition, mirrored by communal hatred between people from the eastern districts, collectively called firaku, versus those from the western districts, called kaladi. ${ }^{36}$ Tens of thousands of people were displaced from their places of residence in Dili, and there was fear that this would reverberate into the districts. While the Fretilin government scrambled to address the situation, the opposition-centered on former resistance hero Xanana Gusmão and his allies in the Democratic Party (PD) and the PSDsought to bring down the Fretilin government. Under intense pressure, Prime Minister Mari Alkatiri resigned, international peacekeepers were 
called in, and the United Nations established a new mission to address the crisis and guide the country through the scheduled 2007 elections.

In the first round of the 2007 presidential election voters in Maubara swung dramatically away from the Fretilin, whose candidate Francisco "Lu Olo" Guterres is from the east. In the villages of Guguleur, Guico, and Vaviquinia voters favored the Liquica-born PSD candidate Lucia Lobato, despite the fact that the latter two villages had voted for Fretilin candidates two years earlier. In Vatuvou, Lissadilla, and Maubaralissa voters overwhelmingly cast ballots for the ASDT candidate, Francisco Xavier do Amaral, who was allied with Gusmão. ${ }^{37}$ In Vatuboro, the PD candidate, Fernando "Lasama” de Araujo, won by a modest margin. Viewed in terms of the crisis, the results in Maubara were a clear vote against Fretilin and strong provincial identification with the western districts. But none of these candidates qualified for the second round, which pitted Fretilin's Guterres against Timor's most famous diplomat and interim Prime Minister José Ramos-Horta. With such a stark choice, Ramos-Horta won by a landslide in Maubara, and was the eventual winner of the national poll as well.

Suco-level results are not available for the 2007 national legislative election in Maubara, but it appears that Gusmão's new party, CNRT, and the electoral alliance between ASDT and PSD won in most of the villages (with the possible exception of Vatuboro, where PD polled strongly). The crucial issue here is not the precise outcome but the positioning of local elites. In Guguleur, the descendants of the Doutels favored ASDT, but most sources believe that CNRT probably won. On the south side of the mountain, in Guico village José Lino dos Reis remained a Fretilin loyalist, as too did the leading dato family in Lissadilla, but their influence had waned and ASDT-PSD won in the former and CNRT in the latter. In Maubaralissa, Rui Manuel da Silva and his immediate relatives voted CNRT, while their more distant relative Miguel Sanches led the ASDT faction. In sum, while elite divisions remained important, overall the fear generated by the 2006 crisis largely overrode historical allegiances and even inter-suco rivalries. Nationally, no party won an absolute majority, and eventually Gusmão's CNRT, the youth-based PD, and the mestizo-dominated PSD formed a coalition government called the Parliamentary Majority Alliance.

As prime minister, Gusmão first focused his attention on the most pressing legacies of the crisis: the military petitioners, the renegade military 
police commander Major Reinado, and the tens of thousands the internally displaced people. In the bigger picture, AMP premised governance on massive increases in the annual state budget, drawn from Timor-Leste's rapidly growing Petroleum Fund. With very low state capacity and a growing conviction within Gusmão's inner circle of the importance of stimulating the private sector, the budget made possible a two-pronged approach: on the one hand, direct cash transfers (to the military petitioners, veterans, the elderly, etc.) and a variety of subsidies (including for electricity, rice, health care, etc.) targeted at the general population; on the other hand, distribution of large and small government contracts to Timorese business people (including critical political actors like veterans, but also amenable members of the opposition) to import goods, build roads, install electrical lines, and an array of other developmental projects. Money flowed freely. The greatest benefits were observed in Dili, where politicians and instant businessmen built glitzy new houses and purchased expensive cars, though there was some trickle down to rural villages as well.

In Maubara, the boom meant that the coastal road connecting Liquica to Dili was repaired and funds were allocated to rebuild primary schools. In the hamlets and villages, however, little changed. Just how the population would vote in the 2012 election was far from clear: vote to keep the budgetary tap open wide and continue to benefit from a few subsidies and the promise that development would extend beyond the coast, or support the opposition, of which Fretilin was the only serious contender?

The 2012 elections in Maubara revealed the continued dominance of national politics and the renewed influence of traditional local elites and their rivalries. In the first round, held in March, PD's Fernando "Lasama" de Araujo won in six of the seven villages in Maubara, but he came in a distant third in the national vote. The two finalists in the runoff, which was held in April, were Taur Matan Ruak, an easterner who fought in the resistance, commanded the defense force (F-FDTL) until his retirement in 2OI2, and was backed by Prime Minister Gusmão, and Fretilin's Francisco "Lu Olo" Guterres, also an easterner and a veteran of the resistance (though primarily in civilian, not military, capacities). In the second round voters in six of the seven villages in Maubara shifted their votes to Taur Matan Ruak, signaling a unified preference for Gusmão's leadership. The one exception was Guguleur, where Fretilin's Lu Olo won by a comfortable 
margin. The outcome in Guguleur appeared exceptional at the time, but it was not. In the national parliamentary election, held on 7 July, the outcome was hotly contested and geographically divided. CNRT outpolled Fretilin by more than I3 percent in Vatuboro and by I6 percent in Lissadilla, and won narrowly in Maubaralissa. Meanwhile, Fretilin outpolled CNRT by II percent in both Guguleur and Guico, and by 5 percent in Vatuvou. PD polled third in five of the seven villages. Even with a large number of minor parties receiving votes, Fretilin won the subdistrict.

The election in Maubara showed the continued dominance of national polarization. The only significant outlier in Maubara was the 7 percent showing in Vatuboro by an upstart monarchist party. Of the four villages that historically were home to "dynastic" families, Fretilin won three (Guguleur, Vatuvou, and Vaviquinia), and CNRT only one (Maubaralissa). The two historic subpolities that had been appointed to assist the Loro Liurai (Vatuboro and Lissadilla), however, all voted for CNRT. And how did the descendants of the dynastic rulers vote? There is no simple answer to this question. In Guguleur, Mau Kuru's relatives had supported ASDT five years earlier but were now firmly behind Fretilin and appear to have wielded some influence in other hamlets as well. In Vatuvou, D. Carlos's descendants were sharply divided between Fretilin and CNRT, and the outcome was a narrow Fretilin victory. In Vaviquinia, where the Nunes family had provided the last two régulos but retained little influence, Fretilin won. In Maubaralissa, allegiances were particularly complicated. In 2005, Mauvili's descendant Rui Manuel da Silva had run as the Fretilin candidate and in 2010 his younger brother Lourindo, who was also a Fretilin supporter, had been appointed subdistrict head. In the 2012 election, they continued to back Fretilin, though political office provided few real resources with which to sway voter decisions. Former clandestine activists, including Miguel Sanches, had become disillusioned with Fretilin's failure to recognize their contributions during the Indonesian occupation and the party's opportunistic selection of local representatives. Miguel Sanches and many of his relatives and friends had first defected to ASDT, and in 2012 were left with no choice but to back CNRT. In sum, long-standing party allegiances had been reversed, but historically salient cleavages within Maubara were maintained and mirrored by supralocal cleavages. 
The postindependence elections reveal both the continued salience of historical legacies in Maubara and their transformation within national narratives. Neither the descendants of the first liurai in Guguleur nor those of the first liurai in Vatuvou have contested local elections or become local representatives of national political parties. Even so, these families continue to exert some influence both as focal points within their village units and via the network of houses (uma) with which they are allied. Despite historical variation in their attitudes toward supralocal power and experience during the Indonesian occupation (the Doutels hostile to outsiders and supportive of the resistance, the old ruling family in Vatuvou having risen through collaboration with the Portuguese in the I85os and with much less claim to militant opposition to Indonesia), both are deeply skeptical of the national elites in Dili. The old dato families in the Loes River valley, who participated in the nineteenth century rebellions and the armed struggle in the I970s, remain pro-Fretilin but have lost much of their influence within the suco. In the end, it is less the case that traditional or historical authority is a source of local allegiances and political leadership in Maubara, and perhaps more that public attempts to make claims in the present based on dynastic authority are likely to elicit hostility from others within the same suco and rival elites elsewhere in the subdistrict. For every claim there are counterclaims, some based on rival accounts of precedence, others on service in the resistance or loss, and still others on the more recent ideals of national sovereignty and citizenship.

\section{Conclusion}

As was the case under indirect Portuguese rule in the second half of the nineteenth century, during the brief Japanese occupation, and throughout the long Indonesian occupation, the atrocities committed before and after the referendum were the result of forces that lay well beyond Maubara itself. What sets the final spasm of violence in I999 apart from previous episodes is not its scale or intensity but rather that the immediate perpetrators-the people who made threats, wielded weapons, tortured, and killed-were overwhelmingly people from Maubara, not outsiders. The BMP militia was raised locally, and its primary purpose was to terrorize and physically harm individuals from the same village or neighboring 
villages. This is not at all surprising: ever since the pogroms against the political left in the I96os, the Indonesian state and military had employed civilians to do a great deal of its dirty work. In Maubara, only civilians knew who was active in the clandestine networks and who supported the cause of independence. This inevitably meant that past rivalries and hostilities would color how villagers took sides and who became a target of the militia. It also meant that what was, from the point of view of outsiders, simply the local manifestation of a national phenomenon, was for those in Maubara intensely intertwined with historical claims, lineage and social status, and the deployment of collective identities and loyalties.

This tension between local experience and the national narratives continued well after the violence had been brought to an end. How local experience and national narratives were understood varied greatly at the individual level, making it impossible to generalize. We are on somewhat safer ground when we turn to how entire families and lineages responded to the issues of justice, reconciliation, community, and participation in national elections. The Doutels' experience with the SCU was both disappointing and demoralizing. Mau Kuru's remains had been lost, and as a result the cultural obligation to set his spirit at peace came to haunt the living. Others in Maubara, such as Miguel Sanches, accepted suffering and loss incurred during the occupation as a necessary consequence of the struggle for liberation. Reconciliation and community were another matter. Both Mau Kuru's relatives and Miguel Sanches extended family welcomed Timor-Leste's good relations with the former occupying power, but remained deeply skeptical of efforts by the East Timor Commission for Reception, Truth and Reconciliation to facilitate community reconciliation. They complained about the recruitment of staff with questionable backgrounds; they objected to the blurring of the distinction between serious crimes, which in theory were to be handled solely by the courts, and lesser crimes, for which reconciliation was allowed; and they were the first to point out that the abstraction "community" obfuscated the deep divisions resulting from the long history of violence, resistance, and ambitions in the present. 


\section{Epilogue}

\footnotetext{
$\mathrm{O}$ ver the past several decades there has been an enormous outpouring of scholarship devoted to various aspects of political violence, including riots and rebellions, civil wars and foreign occupation, genocide and politicide, to name but a few of the major categories. For all the variation in foci and methods, it is essential to recognize that the term that lies at the heart of this literature, violence, contains within it at least three partially distinct but overlapping dimensions. The first of these, generally descriptive rather than analytic, simply connotes physical force or coercion, as in Samuel Johnson's mid-eighteenth-century aphorism "the violence of war admits no distinction." The second dimension, normative and oftentimes legal, implies injury, damage, or violation, as in Thomas Hobbes's usage: "Promises proceeding from fear of death, or violence, are no Covenants"; or, from above, that of sanctions and the ability to punish, as in Weber's famous definition of the state's claim to a "monopoly on the legitimate use of physical force" (or, in some translations, "violence"). A third dimension relates to causation, as in the worn phrase "violence begets violence," and implicitly informs expressions such as "cultures of violence," "violent societies," and even "violent environments." Much of the recent scholarship on violence has focused on the first two dimensions, seeking to understand the production of violence and the legal-normative issues concerning victims and perpetrators, rights and violations. But far less attention has been devoted to the implications of the recurrence of mass violence over extended periods.
} 
There is much that we do not know about the early modern history of the island of Timor and present-day Timor-Leste, but no one would dispute the centrality of violence in that story. The conventional historical chronology is constructed around acts of violence: the arrival of the Portuguese and Dutch, armed with vastly superior military technology, in the early sixteenth century; the military campaign that devastated the ritual center Wehali in I64I; the siege of the rebel stronghold of Cailaco in I726; the ongoing state of rebellion that forced the Portuguese to move their capital to Dili in I769; the military campaigns to pacify the populace during the late nineteenth century; the great Manufahi Rebellion of I9II-I9I2; Japanese brutality during World War II; the Viqueque Rebellion and colonial repression of I959; the terrible twenty-four-year Indonesian occupation; and the final spree of violence and displacement in 1999. The markers in this chronology all involve colonial (or neocolonial) coercion or heroic resistance, and in many cases a combination of the two.

The reconstruction of Maubara's history across three hundred years has also revealed the centrality of violence, but it differs from the national narrative in significant respects. At the time of the I726 rebellion Maubara was divided, with the ruler aiding the Portuguese campaign while a number of lesser hamlets sided with the rebels. Five years later, the defeat of the Portuguese military force in the eastern region enabled Dom Francisco Xavier of Maubara to escape from Portuguese suzerainty and declare his allegiance to the VOC, but in doing so Maubara became the target of repeated attacks both by the Portuguese governors in Lifau and their onagain, off-again Topasse and indigenous allies. The territorial transfer first proposed in I85I and finalized in I86I ushered in three decades of lawlessness, intrigue, uprisings, and devastating colonial retaliation. During the middle decades of the twentieth century the people of Maubara, now conquered and cowed, were spared from the terrible destruction resulting from the Manufahi Rebellion, the worst abuses of the Japanese occupation, and the 1959 rebellion, though in each case there were local reverberations as well. And over the course of the final quarter century of violence, Maubara was the site of fierce conflict between the new Timorese political parties in 1975, of invasion and massacre in 1976, of sustained armed resistance until I978, of brutal occupation throughout the I980s and I990s, and of tenacious efforts to achieve self-determination. 
One would think that the recurrence of mass violence over the course of three centuries would have become a prominent feature of the oral tradition in Maubara. But today the people of Maubara seem to know very little about the glories and tragedies of their past, and acts of violence are not central to their own conception of history. There are no stories about the siege of Cailaco in I726, no tales of the intimate alliance with the Dutch East India Company or the repeated Portuguese attacks between I755 and the I79os, only fleeting references to the bitter local rivals for power at the time of the territorial transfer in the mid-nineteenth century, limited narratives about Maubute's last rebellion of I893, little interest in the brutality committed during the Japanese occupation, a reluctance to discuss the details of the party conflict in 1975, and only the most general descriptions of the atrocities committed during the late I970s. The reason for this lacuna in the oral tradition is not that the people of Maubara do not care about the past or that they have been unable to sustain oral traditions (though there may be some truth to this), but rather that they are far more interested in recording positions than in recounting specific acts.

The second dimension of violence-injury, damage, violation-informs the related discourses of postconflict reconstruction and transitional justice. On the one hand, practitioners of transitional justice have viewed past violence as a danger that must be contained. In Timor-Leste this involved seeking justice for violations of human rights and international law, promoting reconciliation between perpetrators and victims, seeking truth to document past wrongs (and thereby provide a warning for the future), and a variety of efforts to make the community whole and "build" the nation. On the other hand, postconflict reconstruction also employed language that intentionally sought to contain violence in the past. The particular circumstances by which Timor-Leste was liberated gave rise to an extreme form of this, in which the collapse of the regime of occupation and the total absence of a state allowed practitioners to treat the territory as a blank slate on which the United Nations and its partners could build entirely new state institutions from scratch. Where transitional justice views the past as a danger, postconflict reconstruction treated it as an opportunity.

Locally, however, both initiatives ran up against the hard reality that the past could not be contained so easily. As chapter 7 demonstrated, 
responses to transitional justice and postconflict reconstruction were colored by solidarities and cleavages that predated both the recent violence of I999 and the longer period of occupation dating from I975. The most notorious atrocities committed by the Red and White Iron militia were in the town of Liquica and Dili, and it is these that received the most attention. Furthermore, even well-intended efforts to pursue justice could make matters worse, not better, as seen in the tragic fate of Mau Kuru's corpse. The people of Maubara did participate in a number of reconciliation processes, though as we have seen not without some contestation. Even the celebration of community, fortitude, and national achievement could give rise to disputes, as seen in the failure to hold a flag raising ceremony in Guguleur. This is not to suggest that transitional justice or postconflict reconstruction in Maubara were failures, but instead to highlight the centrality of long-standing local narratives, allegiances, and rivalries.

The recurrence of violence is central to the national narrative of colonial oppression and indigenous resistance. But Timorese peoples were not inherently or culturally predisposed to violence, as colonial accounts often insisted, nor were they simply divided, as Indonesian officials often claimed to justify annexation in 1975-I976 and distance themselves from responsibility for the atrocities of I999. As the reconstruction of Maubara's history has shown, local solidarities and rivalries mapped on to supralocal dynamics, which in turn intensified and magnified local differences. These cleavages, as we have seen, have remained remarkably consistent over time. The relationship between the national and local narratives is far from certain, however. The national narrative of resistance to foreign rule leaves little room for a family that, having successfully evaded the colonial villain, was for a full century an enthusiastic ally of the VOC and Dutch Crown and very reluctantly acceded to the territorial transfer in the I850s. The national narrative highlights the great rebellions against Portuguese rule, but Maubara, which was the site of three decades of resistance and rebellion, is rarely mentioned in discussions of the nation's past.

Having begun this study by inquiring into the murder of Mau Kuru in I999, it is perhaps fitting to return to his relatives for a final illustration of the ongoing interaction among lineages, rivalries, and national narratives. In 2012 Mau Kuru's relatives were finally ready to rebuild the lineage's sacred house. The major lineages in Vatuvou, Maubaralissa, and many 
other localities in the subdistrict had already constructed new houses, so it might appear that the Doutel lineage was now playing catch-up. The new uma lulik was constructed on the exact site where the previous structure had stood, though the design was modified: whereas the house constructed in 1985 had been tall and slender, the new one was shorter and squatter in form (to better withstand the winds at the mountaintop, some said) with a ground-level entrance that could be secured with a lock. Next to the rebuilt uma lulik, the lineage erected a wooden flagpole crowned by a carved rooster. Family members explained that while the sacred house represents origins and spiritual potency, the flagpole is a symbol of the political realm.

But house members disagreed about the plan for the inauguration. Several individuals suggested holding a single ceremony to inaugurate the house and raise the Republic of Timor-Leste flag on the adjacent flagpole, but the senior member of the family responsible for ritual (who lived in Manatuto, not Maubara) said that it was not permissible to mix political affairs with the ritual sphere. He explained further that it was necessary to hold a small ceremony when they placed the sacred items in the house; if this was not done, family members might become sick or even die. This ceremony was planned for 28 April 20I2. This was to be a private ceremony, so relatives from Maubaralissa, Vatuvou, and other localities in the subdistrict were not invited. But the family did extend invitations to two officials-the subdistrict administrator, Lourindo dos Reis da Silva (who did not attend), and the chief of staff from the state secretariat for culture, Lucas Serrão Lopes, who happens to be from Maubara (and did attend). The ceremony involved asking forgiveness and calling the ancestors to bear witness, but there was no ritual speech presenting the lineage's genealogy or history. Although the reconstruction of the house had been made possible by the end of conflict, the aim of this opening ceremony was to celebrate the origins of the lineage, proclaim the potency of its artifacts, and protect the living. The violent past was conspicuously absent.

Over the next few months the family erected two large wooden structures with walls made from flattened bamboo in which to prepare and store decorations, provide shelter for participants and guests, and lay out the banquet that would follow the flag ceremony. Queried as to when the ceremony would take place, family members explained that they were 
waiting for the newly elected president of Timor-Leste, Taur Matan Ruak, to tell them when he would be able to attend. They hoped this could happen before the onset of the rainy season, usually late in the calendar year. When pressed on the planning, however, the men admitted that they had not yet sent a formal request to the president's office. More than six months later, I asked the chief-of-staff to President Taur Matan Ruak about the matter and was told that no request had been received from anyone in Lissalara.

By mid-20I3 the family was planning to hold the flag raising ceremony in August or September and continued to hope the president would be able to attend (although they still had not made an effort to extend a formal written invitation). The plan now called for the lineage's ritual flag to be presented to those in attendance and then officially stored in the new house, and for the national flag to be raised on the flagpole. The reason given for this was that after the restoration of independence the village of Guguleur had failed to hold a flag raising ceremony. That, in turn, was caused by the dispute between the subdistrict administrator, who insisted the ceremony must be held in official village seat (and by virtue of that a stronghold of the former Red and White Iron militia) of Caicasa, and the Doutels, who argued that it should be held at their home in Lissalara, the site of the first rulers of Maubara.

Exactly three hundred years after the visit of a Portuguese trading mission from Macau that resulted in the transfer of the name Francisco Xavier to the ruler of Maubara and the surname Doutel to his descendants, the inauguration of the new sacred house involved far more than just averting danger or recounting the violent past. It was about staking claims in relation to a rival hamlet, positioning itself in relation other lineages in Maubara, and desiring recognition from the new state. And in July 20I4, President Taur Matan Ruak made an official visit to Guguleur to attend a ceremony honoring heroes of the resistance, and while there he and his entourage drove to the peak of the mountain to commemorate the house of King of All, Brave King. 


\section{APPENDIX}

Lineages of Major Families in Maubara 


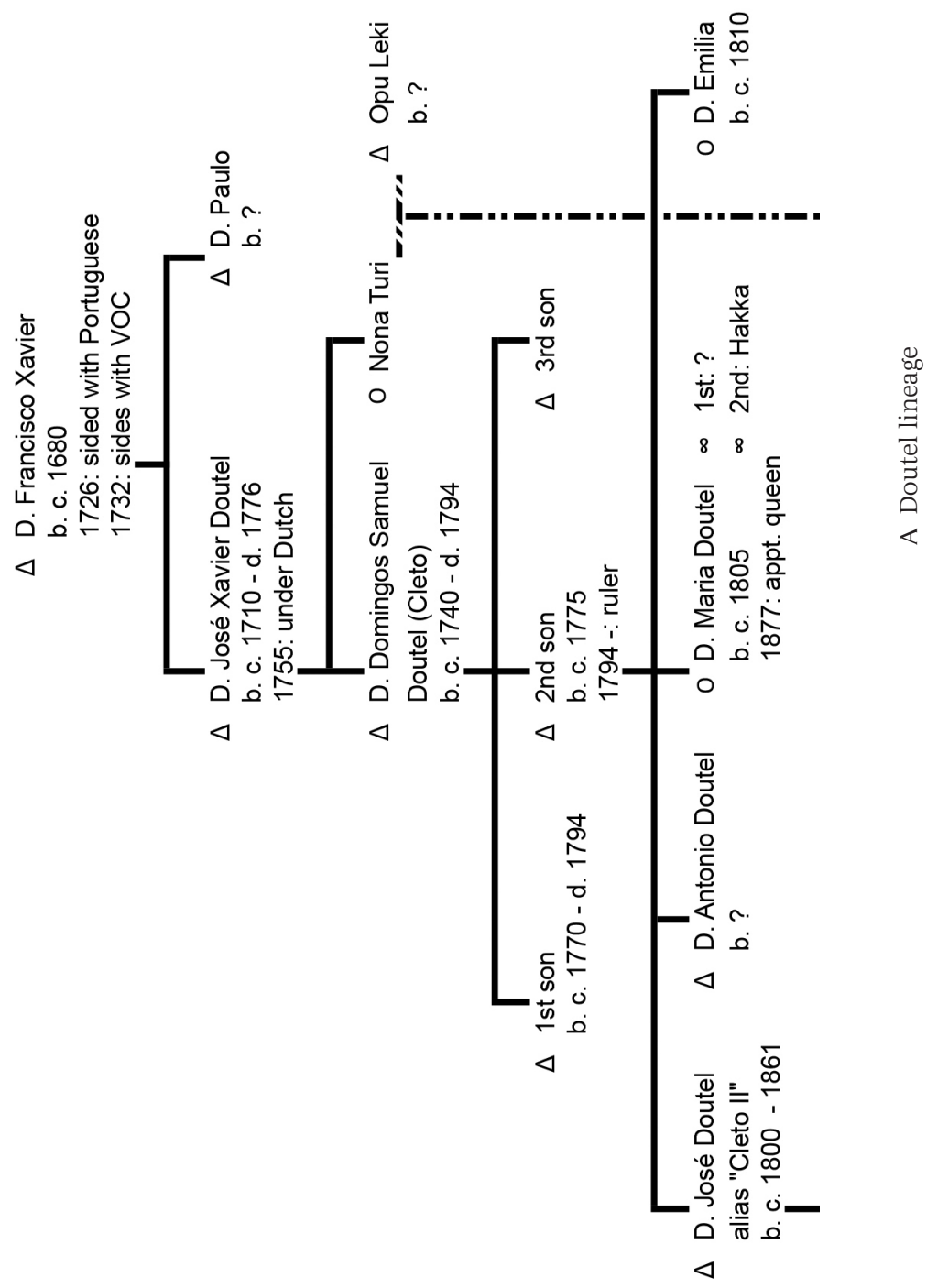




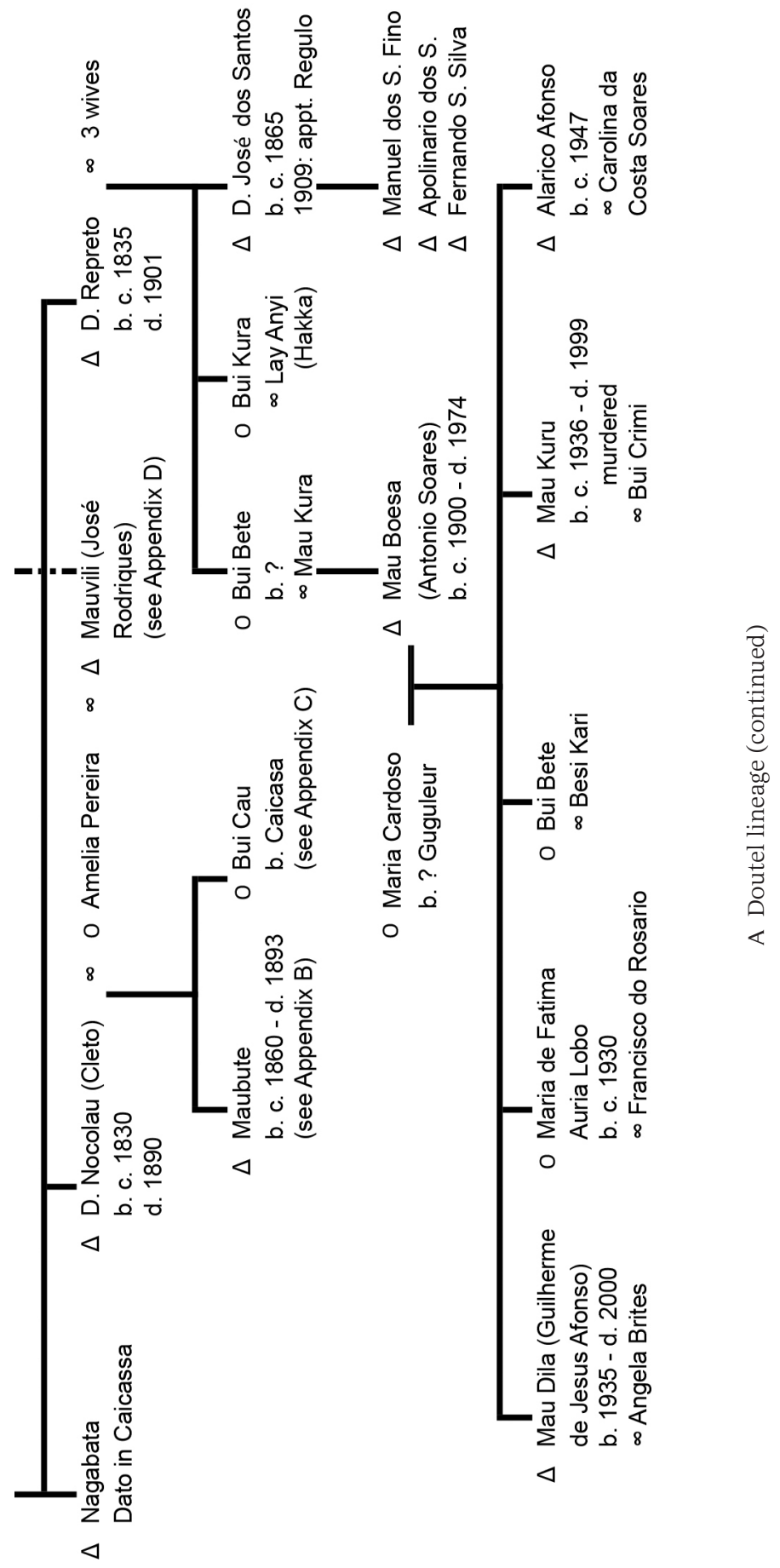



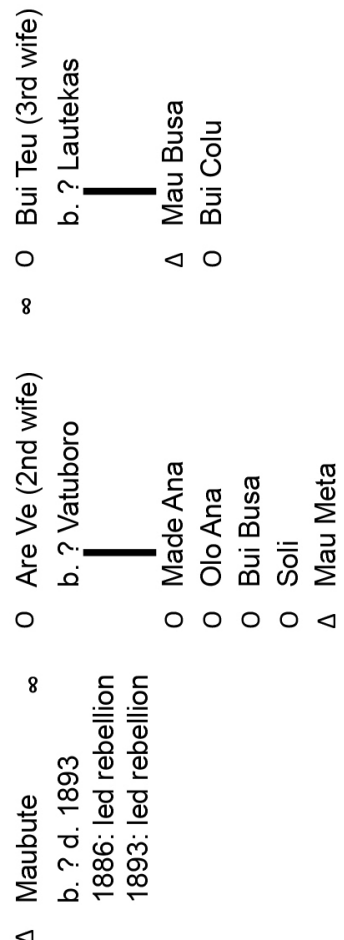

8

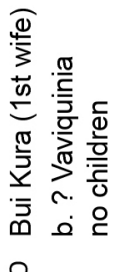

○
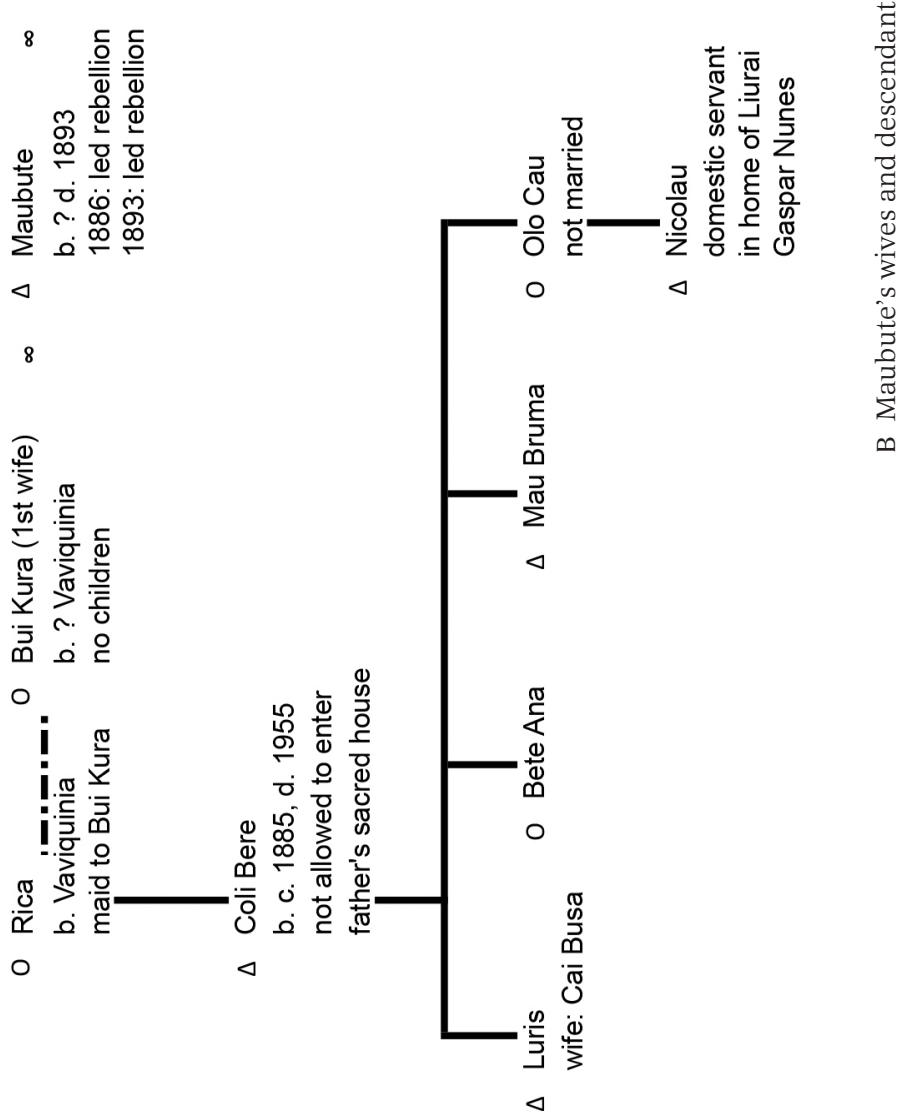


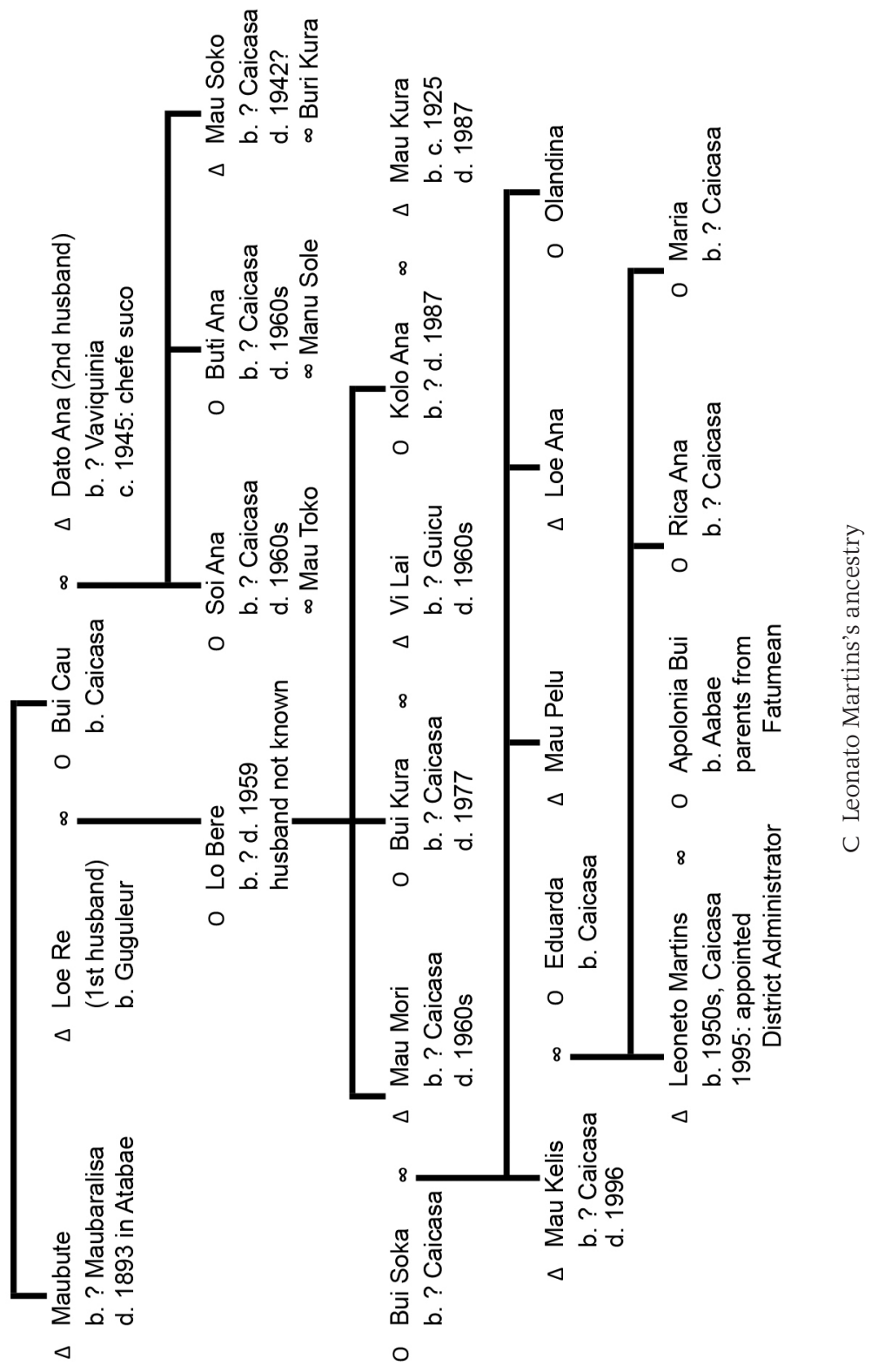




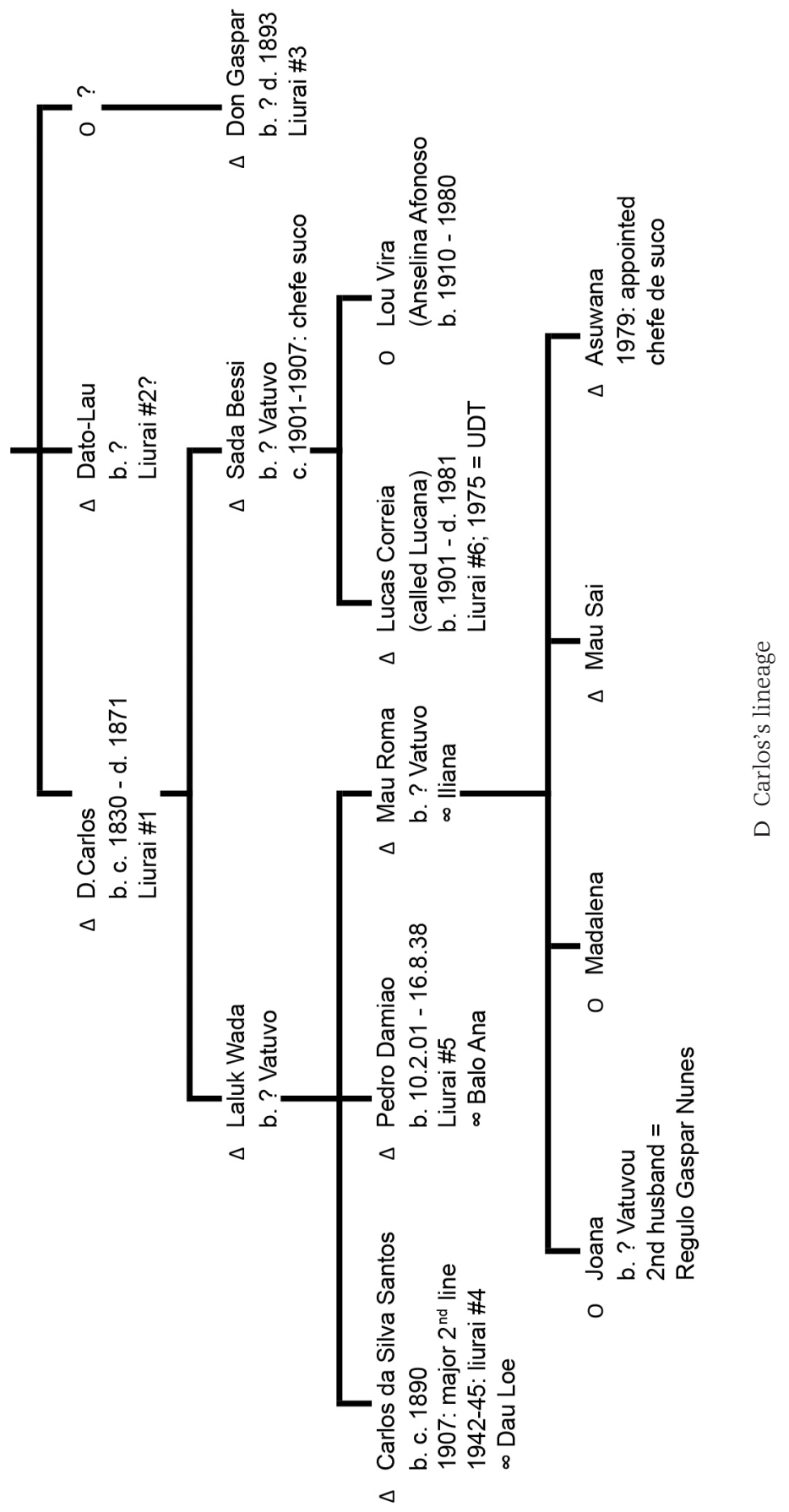




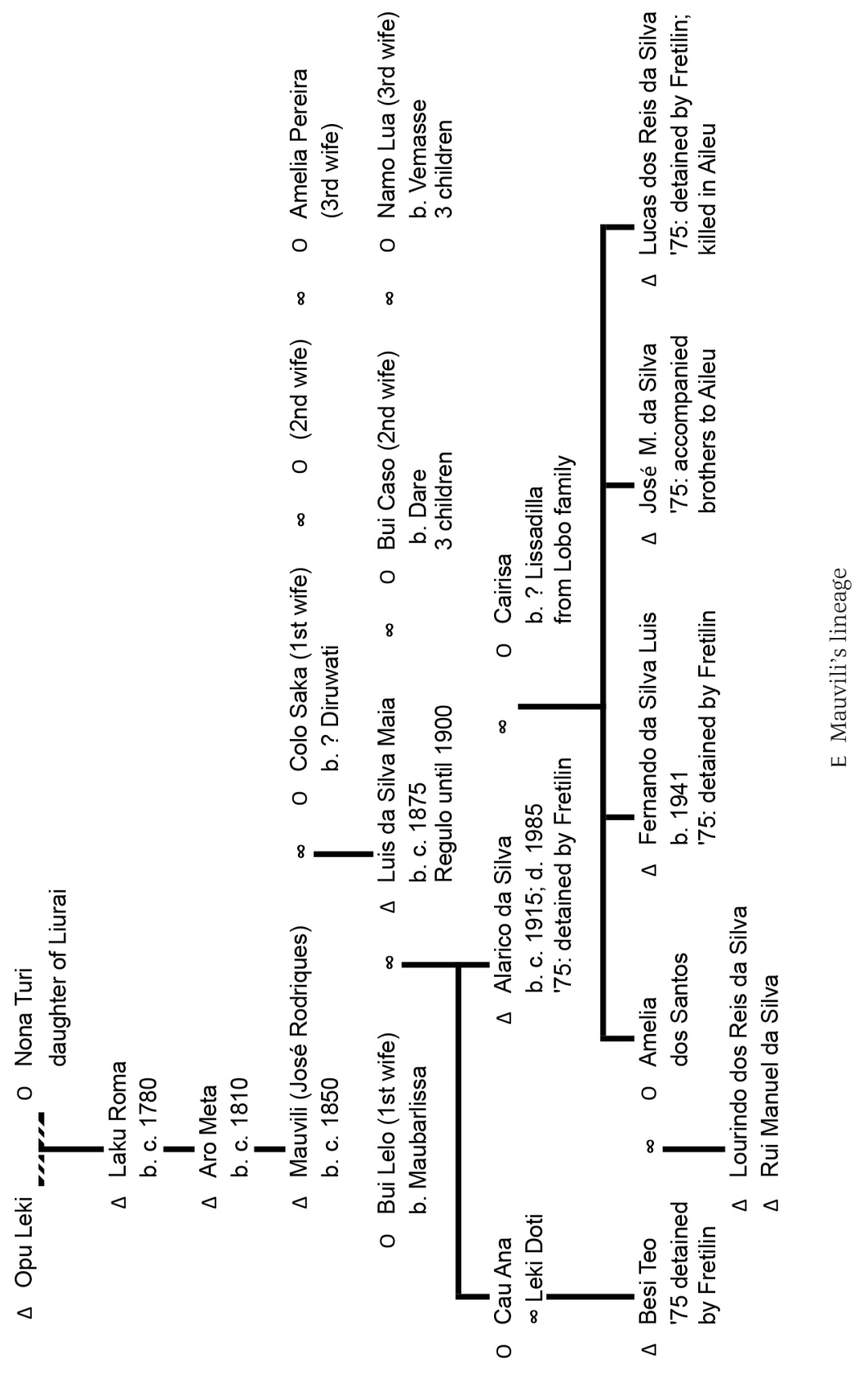




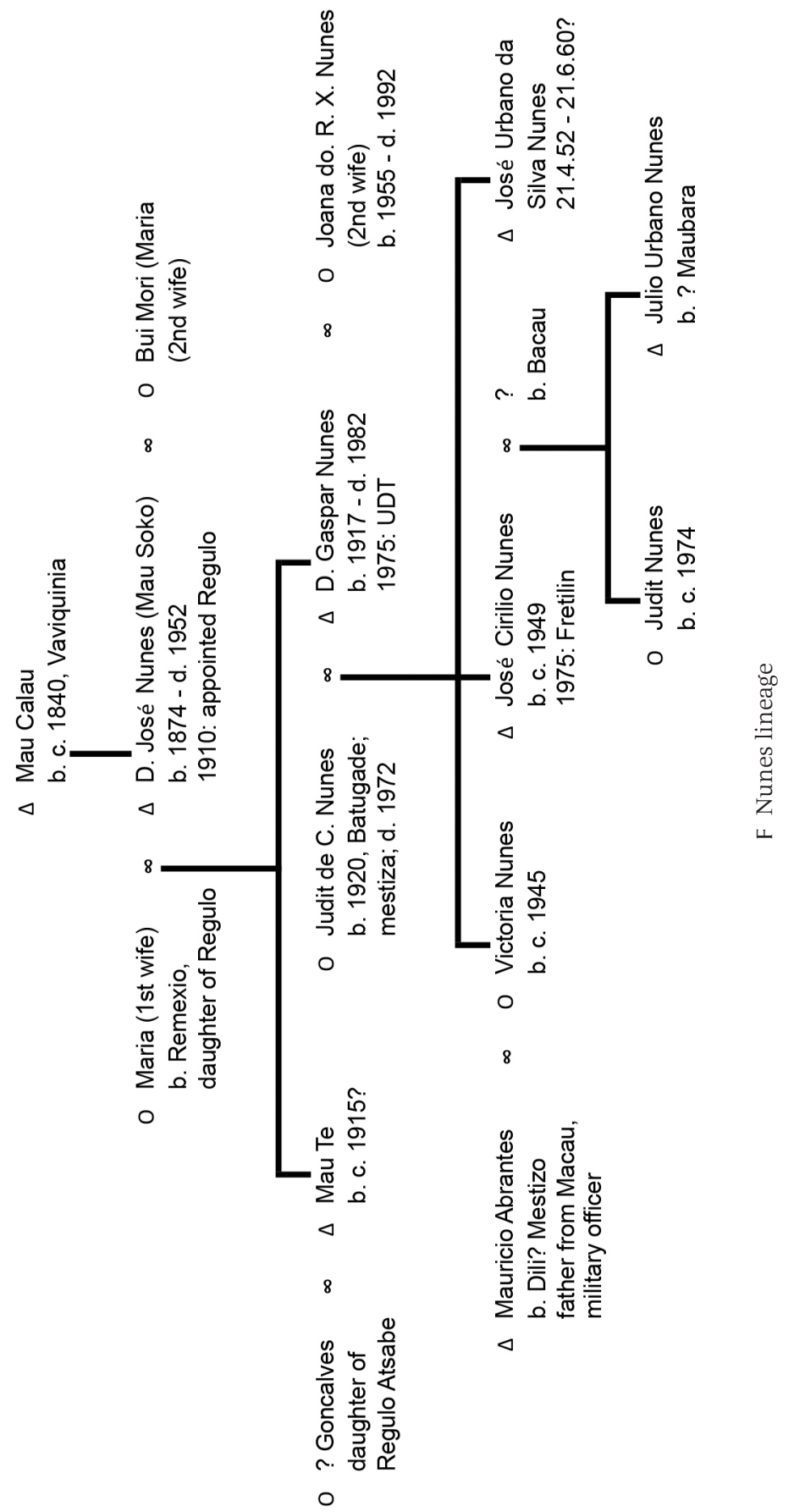




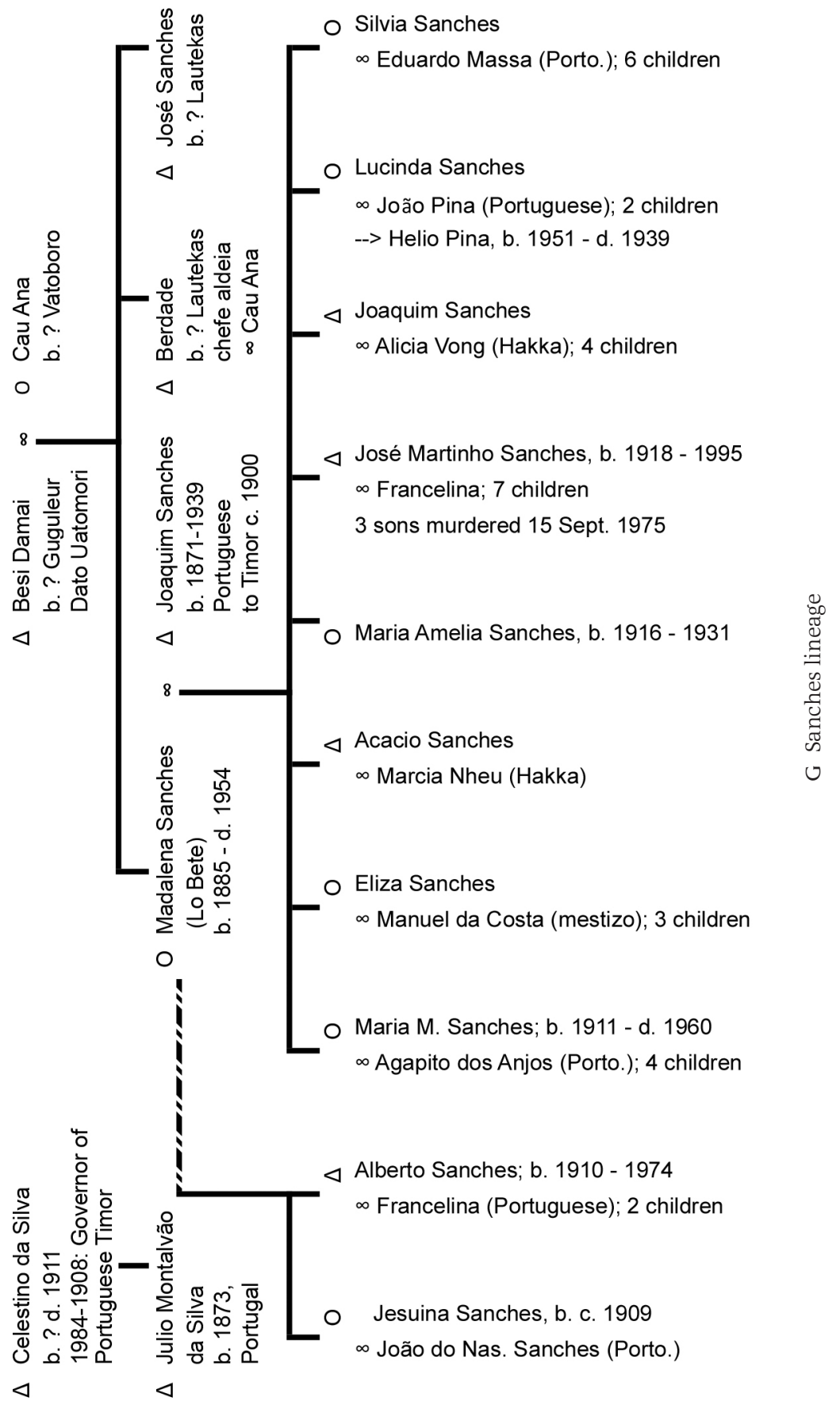





\section{NOTES}

\section{INTRODUCTION}

I. Throughout the I980s and I99os observers commonly estimated that 200,000 people were killed or died unnatural deaths during the Indonesian occupation. Employing statistical modeling of new data, the East Timor Commission for Reception, Truth and Reconciliation calculated a death toll of between I03,000 and an upper (but unlikely) ceiling of I83,ooo. See Commissão Acolhemente, Veridade e Reconciliação (CAVR), Chega! The Report of the Commission for Reception, Truth and Reconciliation in Timor-Leste (Dili, East Timor, 2005), pt. 6, I3.

2. See A. Faria de Morais, Sólor e Timor (Lisbon: Agência Geral das Colónias, I944); Luna de Oliveira, Timor na História Portugal, vols. I-4 (I950; repr., Lisbon: Fundação Oriente, I999, 2004); Artur Teodoro de Matos, Timor Português 1515-1769: Contribuição para a sua História (Lisbon: Faculdade de Letras da Universidade de Lisbon, Instituto Histórico Infante Dom Henrique, 1974).

3. Affonso de Castro, As Possessões Portuguezas na Oceania (Lisbon: Imprensa Nacional, I867), IOI.

4. See, for example, Katharine G. Davidson, "The Portuguese Colonisation of Timor: The Final Stage, I850-I9I2" (PhD diss., University of New South Wales, 1994); Geoffrey Gunn, Timor Loro Sae: 500 Years (Macau: Livros do Oriente, I999); René Pélissier, Timor en Guerre: Le Crocodile et les Portugais (1847-1913) (Orgeval, 1996); and Ricardo Roque, Headhunting and Colonialism: Anthropology and the Circulation of Human Skulls in the Portuguese Empire, 1870-1930 (Basingstoke: Palgrave Macmillan, 20IO).

5. Jill Jolliffe, East Timor: Nationalism and Colonialism (St. Lucia: University of Queensland Press, 1978); Bill Nicol, Timor: The Stillborn Nation (Melbourne: Visa, 1978); James Dunn, Timor: A People Betrayed (Milton, Queensland: Jacaranda Press, 1983).

6. Carmel Budiardjo and Liem Soei Liong, The War Against East Timor (London: Zed Books, 1984); John Taylor, Indonesia's Forgotten War: The Hidden History of East Timor (London: Zed Books, I99I).

7. Peter Carey and G. Carter Bentley, eds., East Timor at the Crossroads: The Forging of a Nation (Honolulu: University of Hawaii Press, 1995); Constâncio Pinto and Matthew Jardine, East Timor's Unfinished Struggle: Inside the Timorese Resistance (Boston: South End Press, 1997); Xanana Gusmão, To Resist Is to Win: The Autobiography of Xanana Gusmão, ed. Sarah Niner (Richmond, Victoria: Aurora Books, 200o). 
8. Amnesty International, East Timor-Violations of Human Rights: Extrajudicial Executions, "Disappearances," Torture, and Political Imprisonment, 1975-1984 (London: Amnesty International, I985); CAVR), Chega!

9. Ian Martin, Self-Determination in East Timor: The United Nations, the Ballot, and the International Intervention (Boulder, CO: Lynne Rienner, 200I); Geoffrey Robinson, "If You Leave Us Here, We Will Die": How Genocide Was Stopped in East Timor (Princeton: Princeton University Press, 20I0).

Io. José Ramos-Horta, Funu: The Unfinished Saga of East Timor (Lawrenceville, NJ: Red Sea Press, 1987).

II. Abilio de Araujo, Timorese Elites, trans. J. M. Alberto, ed. Jill Jolliffe and Bob Reece (Bueanbeyan, New South Wales, 1975); see also Abilio Araujo, Timor-Leste: Os Loricos Voltaram a Cantar (Lisbon, 1977).

I2. Xanana Gusmão, "A History That Beats in the Maubere Soul," 20 May I986, in Gusmão, To Resist Is to Win, Iо3. The word "tribes" is better rendered "polities."

I3. Frédéric Durand, "Three Centuries of Violence and Struggle in East Timor (I7262008)," in Online Encyclopedia of Mass Violence (20II), http://www.massviolence. org/three-centuries-of-violence-and-struggle-in-east-timoroI726.

I4. Helen Hill, Stirrings of Nationalism in East Timor: Fretilin 1974-1978: The Origins, Ideologies, and Strategies of a Nationalist Movement (Otford, New South Wales: Otford Press, 2002); Benedict Anderson, "Imagining East Timor," Arena Magazine 4 (April-May 1993).

I5. The conventional estimate is that at least 40,00o people out of a total population of 450,0oo were killed or died from hunger and disease during the Japanese occupation. Gunn, Timor Loro Sae, 236.

I6. Janet Gunter, "Violence and 'Being in History' in East Timor: Local Articulations of Colonial Rebellion” (Master's thesis, Instituto Superior de Ciências do Trabalho e da Empressa, Lisbon, 2007); see also Geoffrey Gunn, "Revisiting the Viqueque Rebellion of I959” (unpublished manuscript, n.d.), http://geoffreycgunn.com/material/draft_viquequerebellion.pdf.

I7. Ernest Chamberlain, "The Struggle in Iliomar: Resistance in Rural East Timor" (unpublished manuscript, 2003).

I8. Note, however, that anthropologists of East Timor are now turning to the colonial archives. See the forthcoming volume Crossing Histories and Ethnographies, edited by Ricardo Roque and Elizabeth Traube.

I9. Stanley J. Tambiah, Leveling Crowds: Ethnonationalist Conflicts and Collective Violence in South Asia (Berkeley: University of California Press, 1997).

20. "Culture" and "primordial" attachments are often cited as a third major approach to violence and its recurrence, but all too often this is a straw man based on journalistic accounts.

2I. Donald Horowitz, The Deadly Ethnic Riot (Berkeley: University of California Press, 200I), 4I2.

22. Peter Uvin, Aiding Violence: The Development Enterprise in Rwanda (West Harford, CT: Kumarian Press, 1998), 220. 
23. William T. Rowe, Crimson Rain: Seven Centuries of Violence in a Chinese County (Stanford: Stanford University Press, 2007), 2.

24. Mahmood Mamdami, When Victims Become Killers: Colonialism, Nativism, and the Genocide in Rwanda (Princeton: Princeton University Press, 200I); Jacques Bertrand, Nationalism and Ethnic Conflict in Indonesia (Cambridge: Cambridge University Press, 2004).

25. Rowe, Crimson Rain, 9.

26. Edward L. Ayers and Anne S. Rubin, The Valley of the Shadow: Two Communities in the American Civil War (New York: Norton, 2000).

27. Stathis N. Kalyvas, The Logic of Violence in Civil War (Cambridge: Cambridge University Press, 2006), 37I.

28. Tambiah, Leveling Crowds.

29. Hans Hägerdal, Lords of the Land, Lords of the Sea: Conflict and Adaptation in Early Colonial Timor, 1600-1800 (Leiden: KITLV Press, 20I2), 4I4.

30. The best source on militia organizing in I998-I999 and internal militia and military documents in Robinson, "If You Leave Us Here," 92-II4.

3I. CNN, "Rebuilding East Timor Is a Challenge for Returning Refugees and Citizens,” I5 March 2000, http://transcripts.cnn.com/Transcripts/ooo3/I5/ins. oo.htlm (accessed 4 April 2007).

32. Noam Chomsky, "Foreword," in Masters of Terror: Indonesia's Military and Violence in East Timor, ed. Richard Tanter, Desmond Ball, and Gerry van Klinken (Lanham, MD: Rowman \& Littlefield, 2006), ix.

33. Richard Goldstone, foreword to Martha Minow, Between Vengeance and Forgiveness: Facing History after Genocide and Mass Violence (Boston: Beacon, I998), x.

34. Priscilla Hayner, Unspeakable Truths: Transitional Justice and the Challenge of Truth Commissions (New York: Routledge, 2002), I.

35. I worked as a researcher for CAVR from 2002 to 2004 with primary responsibility for research on the Indonesian military.

36. Lia Kent, "Local Memory Practices in East Timor: Disrupting Transitional Justice Narratives," International Journal of Transitional Justice 5 (2OII): 437.

37. For a critique of UN state building highlighting failure to incorporate indigenous sociopolitical practices, see Tanja Hohe, "The Clash of Paradigms: International Administration and Local Political Legitimacy in East Timor," Contemporary Southeast Asia 24, no. 3 (December 2002): 569-589.

38. Dennis Shoesmith, "Timor-Leste: Divided Leadership in a Semi-Presidential System,” Asian Survey 43, no. 2 (2003): 23I-252.

39. Jarat Chopra, "Building State Failure in East Timor," Development and Change 33, no. 5 (November 2002): 979-IOoo.

\section{CHAPTER 1 CONTESTED ORIGINS}

I. See, for example, H. G. Schulte Nordholt, The Political System of the Atoni of Timor (The Hague: Nijhoff, I97I); and for a more recent example, Tom Therik, Wehali: The Female Land: Traditions of a Timorese Ritual Centre (Canberra: Australian National University, 2004). 
2. Elizabeth Traube, Cosmology and Social Life: Ritual Exchange among the Mambai of East Timor (Chicago: University of Chicago Press, I986).

3. Judith Bovensiepen, "The Land of Gold: Risk, Recognition and 'Cultural Revival' in the Central Highlands of Timor-Leste” (PhD. diss., London School of Economics, 20IO).

4. Anthropologists have identified precedence-defined as a concern with socially constructed origins-as a persistent feature of Austronesian societies. For a useful discussion, see Andrew McWilliam, Paths of Origin, Gates of Life: A Study of Place and Precedence in Southwest Timor (Leiden: KITLV Press, 2002), I7-2I.

5. On the "house" (uma) as the basic form of social organization on Timor and throughout the Lesser Sunda region, see the superb contributions in James Fox, ed., The Flow of Life: Essays on Eastern Indonesia (Cambridge, MA: Harvard University Press, 1980).

6. Interviews with Miguel Sanches, 3 August 2003, Maubaralissa, and Mau Dua, I3 July 2003 and 2 May 2004, Lauwana, Maubara; see also Claudia D'Andrea, The Customary Use and Management of Natural Resources in Timor Leste (Oxfam: GTZ-German Technical Cooperation and the Directorate of land and Property of Timor Leste, November 2003), 23. It is possible that the story of the brothers corresponds to the historical exodus of nobles from Wehali and its allied polities, including Suai-Camenassa, after the Portuguese military operation of I64I. Although speculative, see A.D.M. Parera, Sejarah Pemerintahan Raja-Raja Timor: Suatu Kajian Peta Politik Pemerintahan Kerajaan-Kerajaan di Timor Sebelum Kemerdekaan RI (Jakarta: Pustaka Sinar Harapan, 1994), 58.

7. In some versions the population of Maubara was led by a man named Besi Mona Kaimona.

8. Miguel Sanches, interviewed3 August 2003, Maubaralissa. Additional information is from Mau Dua, who claimed to be a descendant of the third brother; interviewed I3 July 2003, Lauana, Maubara. In 20Io David Mearns and Abel dos Santos recorded a long interview with Mau Lelo, Miguel Sanches's father, which they kindly made available and will be cited in the footnotes where there are important discrepancies. See also D'Andrea, Customary Use and Management, 23.

9. Some sources claim that the rank recete comes from the Portuguese rei seti (the seventh king) and repreto from the Portuguese rei preto (the black king); in other versions the three brothers are given the rank of Coronel. Given that the brothers' arrival is supposed to predate the Portuguese and Dutch presence in Timor, either these etymologies are anachronistic or the arrival of the brothers took place after the sixteenth century.

IO. Liurai (literally "above the land") is often translated loosely as Lord of the Land.

II. The word used by my informant was letnan, Indonesian for "lieutenant," but the meaning here is assistant or subcommander, not a Western military rank, which was first introduced in the seventeenth century by the Portuguese and quickly copied by the Dutch.

I2. In another version, the Loro Liurai were also assisted by four "lieutenant colonels" from the kingdoms of Diruwati (Deribate), Mahubo, Atsabe, and Leimean. 
See David Mearns and Abel dos Santos, unpublished transcript of interview with Mau Lelo, Io November 2010.

I3. Ibid.

I4. See David Henley, "Conflict, Justice, and the Stranger King: Indigenous Roots of Colonial Rule in Indonesia and Elsewhere," Modern Asian Studies 38, no. I (2004): 85-I44; Marshall Sahlins, "The Stranger-King or, Elementary Forms of the Politics of Life," Indonesia and the Malay World 36, no. IO5 (2008): I77-I99.

I5. Interview with Mau Dua, I3 July 2003, Lauana, Maubara. For Kolana, see Cora du Bois, The People of Alor: A Social-Psychological Study of an East Indian Island (Minneapolis: University of Minnesota Press, 1944). Hägerdal's meticulous research in the VOC archives has found historical marriage connections between rulers on Alor and the polities of Manatuto and Luca, both in eastern Timor, but no evidence that the Dutch were ever aware of Maubara's claim over Kolana. See Hans Hägerdal, "Cannibals and Peddlars: Economic Opportunities and Political Alliance on Alor, I60o-I850," Indonesia and the Malay World 38, no. III (20IO): 2I7-246.

I6. See, for example, James J. Fox, "Assertion and Silence: Evidence and Entertainment from the Past in Rotenese Oral Dynastic Narratives," and Geneviève Duggan, "Modes of Remembering and Transmitting Knowledge: A VOC Report of I682 and Local Recollections, Island of Savu," both in Tradition, Identity, and History-Making in Eastern Indonesia, ed. Hans Hägerdal (Växjö: Linnaeus University Press, 20II).

I7. Interview with Miguel Sanches, 7 April 2006, Maubaralissa, Maubara.

I8. Wang Ta-yuan, "Tao-I Chih-Lueh Chiao-Chu," dated ca. I345, quoted in Rodney Ptak, "Some References to Timor in Old Chinese Records," Ming Studies I7 (Fall I983): 37-48.

19. This family will be discussed in chapter 3 in connection with the arrival of Hakka settlers.

20. M.A.P. Meilink-Roelofsz, Asian Trade and European Influence in the Indonesian Archipelago between 1500 and about 1630 (The Hague: Martinus Nijhoff, I962), IO2-IO3.

2I. Armando Cortesão and Avelino Teixeira da Mota, eds., Portugaliae Monumento Cartographica, vol. 4 (Lisbon: 196I), 53, plate 4I8c.

22. Matos, Timor Português 1515-1769, 54-55.

23. Letter of the governor general in Batavia to the governor of Formosa, I3 July I626, VOC 853, cited in Leonard Blussé, Strange Company: Chinese Settlers, Mestizo Women and the Dutch in VOC Batavia (Dordrecht: Foris, I986), II6.

24. George Bryan Souza, The Survival of Empire: Portuguese Trade and Society in China and the South China Sea, 1630-1754 (Cambridge: Cambridge University Press, 1986), Io9-III. Much of the Portuguese and the Catholic community in Makassar moved to Larantuca, on Flores, and from there some continued to Lifau, on Timor.

25. I would like to thank Hans Hägerdal, who has examined the VOC archives on Timor carefully, for this information.

26. Matos, Timor Português 1515-1769, I56, 372-373. Governor Guerreiro's I703 list of polities on Timor does not name the ruler of Maubara. For the history of the term callades, which is derived from the Malay/Tetum word keladi, meaning "taro," to refer to mountain dwellers in the western districts, see Douglas Kammen, 
"Subordinating Timor: Central Authority and the Origin of Communal Identities in East Timor," Bijdragen tot de Tal-, Land- en Volkenkunde I66, no. 2/3 (2010): 244-269.

27. Matos, Timor Português 1515-1769, 368: “. . . e os fogidos de Maubara. . . .” I suspect these were Vatuboro and Lissadilla, in the Loes Valley.

28. The name Maubara comes from a legend about a water buffalo of that name that was slaughtered at Tirisvou, in the vicinity of the autochthonous settlements of Ikolau and Kaisave (in present-day Maubaralissa village).

29. For a reconstruction of the military campaign and reproduction of a map depicting the siege of Cailaco, see Oliveira, Timor na História Portugal, 2:543-572.

30. Manuel Teixeira, Os Ouvidores em Macau (Macau: Imprensa Nacional, 1976), 66-70.

3I. Souza, Survival of Empire, I82-I83.

32. Manuel Teixeira, Macau no Séc. XVIII (Macau: Imprensa Nacional de Macau, I984), II8. Caceres's brother Lourenço de Caceres was a military officer serving in Larantuca, the Portuguese base on Flores, as of I702. On the system for allocating rights to the annual trade mission, see Charles R. Boxer, Fidalgos in the Far East, 1550-1770 (Hong Kong: Oxford University Press, I968), I96.

33. The name of the ships are reported in Arquivos de Macau, series 3, vol. 5, no. 4 (I966), 207-208, microfilm boo70, AHM. See also Teixeira, Macau no Séc. XVIII, I25.

34. Names taken from the list in Matos, Timor Português 1515-1769, I45-I6I.

35. W. Ph. Coolhaas, ed., Generale Missiven van Gouverneurs-Generaal en Raden Aan Heren XVII Der Verenigde Oostindische Compagnie, Vol. VI: 1698-1713 (The Hague: Nijhoff, 1976), 6:I9I. This reference is remarkable because the Portuguese capital of Timor and Solor was not Dili but rather Lifau, and Joachim de Matus (sic, Matos) was not governor but a "Capitão mor do Campo" (field captain). See Artur Basilio de Sá, A Planta de Cailaco 1727: Valioso documento para a História de Timor (Lisbon: Divisão de Publicações e Biblioteca, Agência Geral das Colónias, 1949), 73. The most likely explanation for the incorrect identification of the governor is that Portuguese forces sent to subdue the callades rebels at Mount Cailaco in 1726 had remained in the eastern part of the island and sojourned in Dili, where Joachim de Matos was serving as field commander. And what of Lorenzo da Costa? A Portuguese letter from I726 lists Lourenço da Costa as the sargento mor de Macabozo (location unknown). See "Carta de Joaquim de Matos, Capitão-Mor-de-Campo da Província dos Belos,” dated 8 December I726, in Matos, Timor Português 1515-1769, 368.

36. Coolhaas, Generale Missiven, 6:9I. It is worth noting that Portuguese, Dutch, and Makassarese were not the only traders in the region at the time: in I729 a ship owned by a Chinese merchant named Li Hoy Ko was reported to be operating in Timorese waters; ibid., 8:3I.

37. See Boxer, Fidalgos in the Far East, 194.

38. Hägerdal, Lords of the Land, 344. Rouffaer, it seems, was the "old Dutchman" referred to in an account written by José Simões Martinho, the district military commander: "He climbed to the highest point in the kingdom, to the indigenous village of Gu-Leure [Guguleur], at I,200 meters, and visited the old uma-lulic 
[sacred house], where some documents in Malay kept there filled him with contentment. At the sight of some old batons of the liurai, offered by the Dutch East India Company in the time when this kingdom was under the dominion of Holland, the man started to dance." Martinho suspected the man, who claimed to be a naturalist, was in fact a spy. See José S. Martinho, Quatro Séculos de Colonização Portuguesa (Pôrto: Livraria Progredior, 1943), 43.

39. VOC 8354, I760, which reports that Portuguese Governor Monis de Macedo (second term I734-I739) made agreements with a number of kingdoms in the eastern part of the island whereby they could make a one-time payment in return for their freedom from Portuguese suzerainty. Note, however, that this VOC document dates the formal release from Portuguese suzerainty to I737, or five years later than specified in other sources.

40. Castro, As Possessões Portuguezas, 225-226.

4I. This account draws on Teixeira, Os Ouvidores em Macau, 66-70; Manuel Teixeria, ed., Macau e a sua Diocese, Vol. 10: Missões de Timor (Macau: Tipografia de Missão do Padroado, 1974); and Benjamin Videira Pires, A Vida Marítima de Macau no Seculo XVIII (Macau: Instituto Cultural de Macau, I993), I42-I43.

42. I suspect that it was during his brief governorship that the name Doutel was transmitted to families in several other locations in Portuguese Timor, including Batugade (a military commander named Doutel in 1846, a ruling Queen named Doutel in I87I), Manatuto (Doutels in the morador military force in the late nineteenth century), Soibada (where, from the mid-nineteenth century the ruling family has had the name Doutel Sarmento), and Lautem (where in I769 the ruler was D. Luis Doutel).

43. A number of sources incorrectly list Doutel as serving as governor until I748, which is when his successor took office.

44. Calculated from entries in Raphael das Dores, Apontamentos para um Diccionario Chorográphico de Timor (Lisbon: Imprensa Nacional, 1903).

45. In 1903, the first year for which there is a complete tax roll for the entire Kingdom of Maubara, the population was divided into fifty hamlets (povoação), with an average of forty-four taxpaying adult males (meaning those over the age of sixteen) in each. See Boletim Official District Autonom de Timor 4, no. 7 (I4 February I903): 33. If, for the sake of argument, we disregard the large number of young, single male taxpayers and estimate an average family size of five, this suggests a total population of about IO,ooo. This figure is comparable to the I980 census, in which there were 2,546 households, and a total population of II,45O. See Biro Pusat Statistik, Penduduk Propinsi Timor Timur 1980: Hasil Pencacahan Lengkap (I980), 58, 2I2. The intensification of (forced) coffee cultivation after I893 probably resulted in the establishment of many new hamlets as well as a population boom.

46. The ethnically mixed and partially Catholicized community that developed around the Portuguese center of trade first on Flores and later in Lifau, on Timor, was referred to by the Portuguese as "Larantuqeiros" and by the Dutch as "schwarze Portuguezen" (Black Portuguese), and is perhaps best known in the historical literature by the name Topasses (the origin of which remains disputed). 
47. Rui Cinatti's fine study of traditional Timorese architecture does not include an example from Maubara, but the drawings and photographs representing Bobonaro district (the examples of which extend to Hatolia) are typical of the entire area. See Rui Cinatti, Arquitectura Timorense (Lisbon: Instituto de Invstigação Científica Tropical, Museu de Etnologia, 1987), 62-77.

48. On staple crops in early modern island Southeast Asia, see Peter Boomgaard, "In the Shadow of Rice: Roots and Tubers in Indonesian History, I500-I950," Agricultural History 77, no. 4 (2003): 582-6Io.

49. Illustrations from early nineteenth-century Timor can be found in M. Luis de Freycinet, Voyage autour du Monde ... Exécuté sur les Corvettes de L.M. l'Uranie et la Physicienne pendant les Années 1817, 1818, 1819 et 1820 (Paris: Chez Pillet Aîné, I827).

50. On the giving of children in the central mountains of East Timor, see Bovensiepen, "Land of Gold," I73-I79.

5I. For example, writing in 1902 about the importance of instilling Catholic values, Governor Silva wrote, “The Timorese women don't have the faintest notion of modesty and enjoy, whether single or barlaquedas [i.e., married with the bride price paid], maximum freedom. The men are not pre-occupied with what we call the honour of virginity-women are only, for them, instruments of procreation or political tools." Quoted in Davidson, "Portuguese Colonisation of Timor," 223.

52. That a ritual leader was appointed when the brothers from Suai came to Maubara does not mean that there was such a position or figure before this. We simply do not know.

53. For an excellent discussion of landscapes, place, and meaning in the village of Funar, in the central region of Timor-Leste, see Judith Bovensiepen, "Spiritual Landscapes of Life and Death in the Central Highlands of East Timor," Anthropological Forum 19, no. 3 (2009): 323-338.

54. See Hohe, "Clash of Paradigms"; Dionísio Babo-Soares, "Nahe Biti: The Philosophy and Process of Grassroots Reconciliation (and Justice) in East Timor," Asia Pacific Journal of Anthropology 5, no. I (2004): I5-33; Andrew McWilliam, "Introduction: Restorative Custom: Ethnographic Perspectives on Conflict and Local Justice in Timor," Asia Pacific Journal of Anthropology 8, no. I (March 2007): I-8.

55. Interview with Miguel Sanches, 3 August 2003, Maubaralissa, Maubara. David Mearns and Abel da Costa, unpublished transcript of interview with Mau Lelo, I3 October 2010.

56. Transcript of interview with Mau Lelo, I3 October 2010.

57. Meilink-Roelofsz, Asian Trade and European Influence, IO3.

58. Interview with Mau Lelo, 8 April 2006, Maubaralissa, Maubara. Another elder related how his parents had purchased slaves from Alor in the early twentieth century; interview with Mau Dua, 2 May 2004, Lauwana, Maubara.

\section{CHAPTER 2 MAUBARA AND THE DUTCH EAST INDIA COMPANY}

I. Charles R. Boxer, "Portuguese Timor: A Rough Island Story: I5I5-I960," History Today 5 (I960): 354.

2. VOC 8348 , fols. $43-44,1755$. 
3. Oost-Indische Compagnie 1602-1800, I77.

4. See ibid., 87-Io6; Therik, Wehali: The Female Land, 57. Hägerdal, Lords of the Land, 376-38I, provides a fine account of the assembly of nobles in Kupang and raises important questions about hierarchy among the indigenous polities and what the gathering and contract may have meant to those present.

5. A VOC document from I76I provides a list of the "Maubara Kings" (those rulers considered to be subordinate to the company's outpost in Maubara), which again includes both Vatuboro (Dom Pedro) and Lissadilla (Dom Pedro); see VOC 3024, I76I. Oddly, the ruler of Maubara is listed as Dom Luís, when all other documents provide the name José. Given other odd renderings of Portuguese names, this might simply be a mistake by a new scribe. Another possibility is that Dom José Doutel's name was omitted because of his superior status, in which case the Dom Luís on the list may have been the head of the related but rival royal family in the subpolity of Vatuvou.

6. VOC 835I, I758. On Sikka's relations with the Portuguese in the late seventeenth and early eighteenth centuries, see Hägerdal, Lords of the Land, I76-I78.

7. Information provided by Hans Hägerdal, from H. Fiedler, "Hans Albrecht v. Plüskow als Oberhapt von Timor," Deutsche Wacht 5 (I93I): 3I.

8. "MXVII. Timor," dated 27 March I759, in Oost-Indische Compagnie 1602-1800, I77. I would like to thank Jan van der Putten for this translation.

9. VOC 8354,1760 .

IO. VOC 8354, I76o. Information is not available about the number of Europeans involved in Paravicini's military force, but this was undoubtedly quite small, suggesting that at least some of the men posted in Maubara may have been mardijkers from Rote and Kupang.

II. Missive by Opperhoofd Johan ter Herbruggen, in VOC 8358, I764.

I2. Letter from Maubara, dated Io October I764, in VOC 8358, I764. No information is available about conversions during this period.

I3. Note, however, that only five years earlier this same ruler of Motael is reported to have sent a letter to Dom José Xavier Doutel of Maubara stating that he was leading four thousand armed men in an attempt to destroy the Portuguese settlement of Dili. Reported in VOC 3I5I, I765.

I4. Matos, Timor Português 1515-1769, I56.

I5. VOC 3553, I779.

I6. VOC 7440, I788. The stone fort measures sixty by seventy-one meters; see Direktorat Perlindungan dan Pembinaan Peninggalan Sejarah dan Purbakala, Pengumpulan Data Peninggalan Sejarah dan Purbakala di Daerah Tingkat I Timor-Timur (Departemen Pendidikan dan Kebudayaan, 1984), 59. Some time later the Dutch also constructed a large Protestant church to the west of the fort.

I7. Hägerdal, Lords of the Land, $4 \mathrm{O} 2$.

I8. For the Maubara-Senobay alliance, see the Sarzedas Document, in Morais, Sólor e Timor, I63, and Castro, As Possessões Portuguezas, I04.

19. Hägerdal (Lords of the Land, 422) has found an archival reference to a new ruler in 1794 named Nyong Mas. This is not a Tokodede name, and in fact looks 
suspiciously like a corruption of Balinese names (Sang Nyoman, Nyoman Mas, or some variant of this).

20. Comité Oost-Indische Handel en Bezittingen, National Archive, The Hague, No. IO2, I794-I795.

2I. That the VOC gave the rulers of Maubara canes of office is confirmed by Martinho, Quatro Séculos de Colonização Portuguesa, 40-4I. The Portuguese naturalist Alberto Osorio de Castro, who visited Guguleur during his three-year stay in Timor from I909 to I9I2, reported seeing the Doutel family heirlooms: "À luz de archotes vai-nos o chefe mostrando bastões de régulo com as armas e emblemas da Oost Indische Compagnie . . . , um tambor-caixa de bronze com o leão neerlandês e um lema da Companhia; uma ponta de elefante denegrida pelo fumo, idoloshinhos de ferro de talvez um palmo, duas terra-cotas chinesas, uma representando um galo, e a outra um dragão, velhas vestimentas esfarrapadas e irreconhecíveis, dois altos tamboirs de madeira, ornados, cercados de figurinhas soltas de pau, a servirem de cavilhas de registo, e outras vestustas coisas fuliginosas e sem nome. Ao lado da Uma-lúlic um altar de pedra, com um poste para a deposição dos chifres ou dos ossos dos animais sacrificados" ("By the light of torches the chief shows us the canes of office of the ruler and the weapons and emblems of the East India Company ... . a bronze drum with a Dutch lion and symbol of the company; an elephant tusk blackened by smoke, little idols made of iron about the size of the palm of a hand, and two Chinese porcelains, one representing a rooster, the other a dragon; old, ragged, and unrecognizable clothes; two high wooden drums, ornate and surrounded by loose figures of wood, which serve as the pins of the register; and other old things sooty and without name. By the side of the sacred house there is a stone shrine with a place to put horns or bones of sacrificed animals"). Alberto Osório de Castro, A Ilha Verde e Vermelha de Timor (Lisbon: Divisão de Publições e Biblioteca Agência Geral das Colónias, 1943), IO.

22. These coral beads are called calu in Tokodede and mortel in Tetum.

23. See Steven Farram, "Jacobus Arnoldus Hazaart and the British interregnum in Netherlands Timor, I8I2-I8I6," Bijdragen tot de Taal-, Land- en Volkenkunde I63, no. 4 (2007): 455-475.

24. Arsip Nasional Republik Indonesia (ANRI) Timor, 2I, I8I2. See also Farram, "Jacobus Arnoldus Hazaart," 468.

25. For the I8I5 list, see Manoel José Gomes Loureira, Memorias dos Estabelecimentos Portuguezes a L'este do Cabo da Boa Esperança (I835), 234-235.

26. See Helder Lains e Silva, Timor e a cultura do café (Porto: Imprensa Portuguesa, Memórias Serie de Agronomia Tropical, I956); Gervase Clarence-Smith, "Planters and Smallholders in Portuguese Timor in the Nineteenth and Twentieth Centuries," Indonesian Circle 57 (March 1992): I5, rightly notes that coffee was probably first introduced in the mid-eighteenth century. A Portuguese document from I734 suggests that coffee was being cultivated in Timor at precisely the time Maubara purchased its independence from Portuguese overlordship; see Castro, As Possessões Portuguezas, 245. 
27. H 548, KITLV, H 73I, KITLV, examined by Hans Hägerdal. In a subsequent published report, Francis writes, "The king of Maubara rules over a population of 87,0oo souls." E. A. Francis, “Timor in I83I," Tijdschrift voor Neêrland's Indie I, no. I (I838): 360 . This figure is impossibly high for Maubara alone, so it appears to refer to the subjects of the "Maubara kings" throughout north-central Timor, which were still considered to be subvassals of Maubara.

28. Brouwer, "Nota betreffende Timor," H 73I, KITLV, examined by Hans Hägerdal.

29. Herman Melville, "Whaling in the Straits of Timor," Knickerbocker, April I859, 349-359. The whaler on which Melville served, the Acushnet, was in the Timor Strait sometime between January I84I and July I842. The ship's log has never been found, so it is not possible to determine if the crew gathered information about Maubara or visited other ports on Timor.

30. Singapore Chronicle and Commercial Reporter, I9 November I836, 2. From the diary of the ship's surgeon, we learn that the original deal had involved the exchange of “ 3 Buffalo, Io Sheep, I8 Goats, I pig and 3 dozen fowls” for a specified quantity of gunpowder. Joan Druett, Rough Medicine: Surgeons at Sea in the Age of Sail (New York: Routledge, 2000), I93-I94.

3I. Singapore Chronicle and Commercial Reporter, 3 December 1836.

32. Mau Dua, interviewed on 3 August 2003, Lauana, Maubaralissa, Maubara.

33. David Mearns and Abel da Costa, unpublished transcript of interview with Mau Lelo, I3 November 20IO; for Oecusse's claims on Alor, see Davidson, "Portuguese Colonisation of Timor," 66.

34. Davidson, "Portuguese Colonisation of Timor," 66; transcript of interview with Mau Lelo, I3 November 2010.

35. A decade earlier, an astute Chinese visitor to Timor wrote a list of recommendations for the Portuguese government in which he estimated that taxes were paid on only 25 percent of the sandalwood and beeswax collected in the Portuguese territory, the remainder being sold into Dutch territory. See Kem Yuen [?], "Projecto do melhoramento do estabelecimento de Timor, offerecido pelo china. ... Que estado muitos annos nessas ilhas," in Annaes Maritimos e Coloniaes, Lisbon, 3rd ser., official section, 2 (I843): 7I-73.

36. "Nederlandsch-Portugeesche Commissie vour Timor Gouvt. . . gedaan in do jaare I85I \& '52”; see also Gunn, Timor Loro Sae, I47-I49.

37. P. J. Veth, "Het Eiland Timor," De Gids I9, no. 2 (1855): Ioo, cited in Paul van der Velde, A Lifelong Passion: P. J. Veth (1814-1895) and the Dutch East Indies (Leiden: KITLV Press, 2006), I37.

38. "Colonial Boundary Treaty between The Netherlands and Portugal, Signed at Lisbon, 20 April I859," in Heike Krieger, ed., East Timor and the International Community: Basic Documents (Cambridge: Cambridge University Press, I997), I-2.

39. L.W.A. Kessler, "Eene vredesluiting op het eiland Timor en de overgave van het koninkrijk Maubara aan het Portugeesche gouvernement," Bijdragen tot de geschiedenis van Nederlandsch Indië (I89I): 255. 
40. One source says Datu Lau was Dom Carlos's older brother, who was "stupid" and did not hold a position of authority. Interview with Mau Lelo, 8 April 2006, Maubaralissa, Maubara.

4I. This "Mau-Lay" may well have been a Hakka merchant, who was called "raja" because he was the head of the Chinese community, or at the very least the point man in relations with Hakka merchants elsewhere.

42. Kessler, "Eene vredesluiting op het eiland Timor," 255-256.

43. Ibid., 257.

44. Ibid., 258.

45. The Hakka are a dialect group from China. Most Hakka in Portuguese Timor emigrated from Meizhou county in Guangzhou; the Hakka in Maubara seem to have come from the village of Xinning.

46. Personal communication with Mau Dua, 3 August 2003, Lauana, Maubaralissa, Maubara. This was to have repercussions in the I960s and again in the I99os, as discussed in subsequent chapters.

47. Castro, As Possessões Portuguezas, I74, 457-458. Castro was appointed governor on 8 September 1859 .

48. ANRI Timor, IO3, examined by Hans Hägerdal; Oliveira, Timor na História Portugal, 2:43.

49. Governor Affonso de Castro's I864 account of the I86I rebellions identifies "Fatupró" as one of the rebellious polities, but he does not identify its location. The location is positively identified as Vatuboro (but the year incorrectly implied to be I867) in Governor Forjaz's "Guerra de Maubara," 2, dated I5 December I893, Processo 376, AHM. See also Oliveira, Timor na História Portugal, 2:43.

50. Dom Carlos was a descendant of the eldest of the three brothers from Suai, discussed in chapter 2. See appendix B for the family lineage.

5I. See Davidson, "Portuguese Colonisation of Timor," I47. This may correspond to the I867 "rebellion" mentioned in Pélissier, Timor en Guerre, 74.

\section{CHAPTER 3 VASSALAGE AND VIOLENCE, 1861-1887}

I. For a fine comparative overview of the impact of colonialism on elites in nineteenth-century Southeast Asia, see Ruth McVey, "Local Voices, Central Power," in Southeast Asian Transitions: Approaches through Social History, ed. McVey (New Haven: Yale University Press, I978), I2-I7.

2. Francisco Cravasfos Valdez, Da Oceania a Lisboa (Rio de Janeiro, I866), 35-37.

3. Gunn, Timor Loro Sae, I27.

4. Letter of Alfredo de Lacerda Maia, 2 July I886, in IR-0o2, CX.005, AHU.

5. Pélissier refers to this incident as a "revolt" and reports that Vatuboro was required to pay one thousand rupees in indemnities; see Pélissier, Timor en Guerre, 74.

6. José S. Martinho, Os portugueses no Oriente: Elementos para a História da Ocupação de Timor (Lisbon, I938), 8; Jorge Barros Duarte, “Timor pré-colonial,” Leba I (1992).

7. Davidson, "Portuguese Colonisation of Timor," 69.

8. Pélissier, Timor en Guerre, I05. 
9. According to one oral account, Dom Gaspar was murdered by Mauvili, whom we will encounter shortly. Interview with Mau Lelo, 3I May 2003, Vatuvou, Maubara.

Io. Boletim da Provincia de Macau e Timor (BPMT) 28, no. I5 (6 April I872): 57.

II. BPMT 28, no. 43 (I9 October 1872): II8. Surprising at this may seem, in the I86os-I870s the Portuguese requested Dutch assistance on a number of occasions; see Davidson, "Portuguese Colonisation of Timor," 69-70.

I2. Clarence-Smith, "Planters and Smallholders"; Davidson, "Portuguese Colonisation of Timor," 89-94.

I3. See Clarence-Smith, "Planters and Smallholders," I, for export figures in the I86os; on Maubara's reputation, see BPMT I6, no. 45 (7 November I870): 190. In I883, Maubara was still the largest producer of coffee, with an output of thirteen thousand piculs; Davidson, "Portuguese Colonisation of Timor," 93.

I4. These individuals are remembered by the names A Sung and Loi Moi (or perhaps Boto Ana). Interview with Antonio Sanches and Agusto Afonso, I4 April 2006, Erito, Maubara.

I5. There are many conflicting stories about Dona Maria, including one in which it is said she was once married to a Portuguese military officer.

I6. Pélissier claims that the Chinese population of Maubara in the I880s reached three hundred, an impossibly high figure. See Timor en Guerre, IoInIIo, apparently based on José dos Santos Vaquinhas, “Timor," Boletim da Sociedade de Goegrafia de Lisboa 4, no. 7 (I883).

I7. See, for example, BPMT 32, no. 5 (4 February I886): 27.

I8. Letter of Alfredo de Lacerda Maia, 2 July I886, IR-002, Cx.005, AHU.

19. Portuguese usage in Timor seems to differ from that of the Spanish in the Philippines, where the term principal refers to the nobility in general.

20. Terms of vassalage, agreed on I4 March I877, published in BPMT 23, no. 22 (2 June I877): 9I. The name given in the terms of vassalage is "Nocurai," a poor rendering of "Nocolau"; in later documents he is referred to as "Nicolau" or "José Nicolau."

2I. In some oral accounts she is said to have been D. José Doutel's aunt. Governor Forjaz, however, reported in I893 that Maria was his sister. See Document 2, dated 3і May 1893, attached to "Guerra em Maubara," Processo 376, AHM. Oral sources today refer to her as Dona Maria, Queen Maria, and even Maria Magdalena. Note that the queen of Cova in I870 was a woman named Dona Maria Michaela Doutel da Costa; despite the similarity in name, it has not been possible to find any connection between the two women.

22. Pélissier, Timor en Guerre, I05, refers to him as D. José Calau. Agusto Afonso, interviewed I4 April 2006, in Erito, was certain that these names all refer to the same individual.

23. On the proliferation of reigning queens in nineteenth-century Timor, see Douglas Kammen, "Queens of Timor," Archipel 84 (2012): I49-I73.

24. A fourth signatory was Mabussa (sic, Maubussa), listed as a tenente coronel, whose place of origin is not known.

25. Letter of Alfredo de Lacerda Maia, 2 July I886. See also letters dated 7 August and 20 August I878, in Ao682, Doc. P. I80, AHM. 
26. "Mappa semanal da força das sobreditos companhias referido a 24 de Agusto da I878," signed by Francisco de Paula da Frj [?], in Ao682, Doc. P.I8o, AHU.

27. "Mappa do movimento religioso das missões de Timor durante dez annos desde I877 a I886," in A Voz de Crente, 30 July I887, 264.

28. Terms of Vassalage agreed to on 23 June I88I, published in BPMT 27, no. 33 (I3 August I88I): 226-227. The other signatories from Maubara included ten nobles (principal and dato), five individuals with a military rank, and two Hakka merchants. Given that there are nineteen individuals who can be identified as being from Maubara, this suggests that the rather mysterious lists of electeurs from each kingdom that were published in the colonial gazette (BPMT I4, no. 30 [25 July I868]: I44, and BPMT 27, no. 45 [5 November I88I]: 333) were based on the number of individuals who participated in the elevation or recognition of the régulo. This varied widely depending on legitimacy and contestation.

29. Davidson, "Portuguese Colonisation of Timor," 93.

30. Alfredo de Lacerda e Maia to Governor of Macao and Timor, I5 April I886, Macao, AC, P-653, AHM, quoted in Ricardo Roque, "The Colonial Command of Ceremonial Language: Etiquette and Custom-Imitation in Nineteenth Century East Timor," in Portuguese and Luso-Asian Legacies in Southeast Asia, 1511-2011, vol. 2, Culture and Identity in the Luso-Asian World: Tenacities and Plasticities, ed. Laura Jarnagin (Singapore: Institute of Southeast Asian Studies, 2012), 79-80.

3I. Letter of Governor Alfredo de Lacerda Maia to the king of Portugal, I7 June I886, IR-002, Cx. 005, AHU. All quotes in this and the following two paragraphs are from this letter.

32. Ibid.

33. A contingent of African troops had arrived in Portuguese Timor in I879; see Pélissier, Timor en Guerre, $3 \mathrm{I} 7$.

34. Letter of Governor Maia, I7 June I886.

35. Ibid.

36. For a discussion of Portuguese entanglement with the "style and customs" (usos e customes) of the indigenous population, see Roque, Headhunting and Colonialism.

37. Letter of Governor Maia, I7 June I886.

38. Letter of Alfredo de Lacerda Maia, 20 June I886, IR-oo2, Cx.005, AHU. See also A Voz de Crente, 7 January I888. For secondary accounts, see Duarte, "Timor précolonial”; and Pélissier, Timor en Guerre, I05. The only oral account that may allude to the governor's savagery on this occasion was from Miguel Sanches, who noted that the Portuguese "burned houses there." Interview, 3 August 2003, Maubaralissa, Maubara.

39. Letter of Governor Maia, 20 June I886.

40. By April I887, a mere 430 meters of road had been built in Maubara; BPMT 33, no. I5 (I4 April I887): I35.

4I. Letter of Alfredo de Lacerda Maia, 2 July I886, in AHU.

42. Martins was a "political" appointee, not a member of the long-standing ruling family of Motael, the Rodrigues Pereirras. 
43. A Catholic priest in Dili claimed the popular resentment against the Portuguese lieutenant stemmed from "abusos forçados de crianças" (sexual abuse of children); quoted in Davidson, "Portuguese Colonisation of Timor," I67.

44. This and the following two paragraphs are based on the testimony of Lucas Martins, document dated I5 March I887, IR-002, Cx.005, AHU. See also Oliveira, Timor na História Portugal, 2:208-216; Davidson, "Portuguese Colonisation of Timor," I66-I69; and Pélissier, Timor en Guerre, Io6-IIo.

45. Anderson points out that thanks to the influence of anarchism, the I88os and I89os marked the great age of political assassinations; see Benedict Anderson, Under Three Flags: Anarchism and the Anti-colonial Imagination (London: Verso, 2005). But it was not until the I89os that the first Portuguese anarchists were deported to Timor, with many more to follow during the early twentieth century.

46. Jacinto Alves, who served as a commissioner with the East Timor Commission for Reception, Truth and Reconciliation, claims that one of his ancestors from Lequidoe, a small polity in Aileu District, was the individual who murdered the governor. Personal communication, I7 July 2003, Dili. In I892 the colonial gazette published in Macau reported that a soldier named R. Raphael Pereira had been convicted of the murder. Boletim Official do Governo da Provincia de Macau e Timor (BOGPMT) 38, no 36 (Sept. 8, I892): 297.

47. BPMT 27, no. 33 (I5 August I887): 226-227.

48. Personal communication with Mau Lelo, 8 April 2006, Maubaralissa. The woman's name was Turi Lau or Nona (miss) Turi.

49. In another version of the story, the ruler of Guguleur evicted his daughter from the family home, she went to find Opu Leki, and her father then took pity on her. Transcript of interview with Mau Lelo, I3 October 20I0, Maubaralissa, Maubara.

50. This supports the contention, discussed in chapter I, that the original families in the Maubaralissa area had a "judicial" function, and also fits with the VOC archival account of 1794 about a ruler in Maubara requesting a VOC emissary from Kupang come to "present him as king. ... according to the customs of the land."

5I. This appears to have taken place in the I880s. In one version, Mauvili refused to assist in the rebuilding of the Doutel family's uma lulik (sacred house), but then showed up for the inaugural ceremony. Not allowed to attend, he returned home and organized the building of a rival uma lulik. Interview with José Maucabae, I6 August 2003, Maubara. Another account tells of a buffalo named Maubara that was released and wandered to Tirisvo, where it was sacrificed and the name Tirisvo was changed to Maubaralissa, which now encompassed a number of hamlets. Interview with Mau Dua, 2 May 2004, Lauwana, Maubara.

52. Interview with José Maucabae, I6 August 2003, Maubara; interview with Mau Lelo, 8 April 2006, Maubaralissa, Maubara.

\section{CHAPTER 4 THE UPRISING AND DEVASTATION OF 1893}

I. See, for example, Cristiano da Costa et al., Exploring Makassae Culture (Baucau: Instituto Católico para Formação de Professores Baucau and Publições Matebian, 2006), 2I-22; for a history of these terms, see Kammen, "Subordinating Timor." 
2. The most comprehensive list of rebellions and colonial military campaigns during this period can be found in Pélissier, Timor en Guerre.

3. Cypriano Forjaz, "Relatorio: a) Causas remotas e provaveis da revolta," signed 29 August I893, countersigned by the General Office of the Government of Macau, I5 December I893, folio I3 in "Guerra de Maubara," Processo 373, AHM.

4. Clarence-Smith reports that by this time there was already one Portuguese planter, but he does not name the individual; Clarence-Smith, "Planters and Smallholders," 9 .

5. "Governo de Timor," BPMT 33, no. 22 (2 June I887): I99, and "Governo de Timor," BPMT 34, no. I5 (I2 April I888): I34.

6. Krieger, East Timor and the International Community, 2-3.

7. "Projecto e orçamento para a construcão da casa de Comando Militar de Maubara (Timor)," dated I June I893, AH/AC/P-I323, Ao7I8, AHU.

8. Governor Forjaz later wrote, "[A] little before my arrival in the district, the ruler D. José died." In “Causas remotas," 29 August I893, folios I3-I4, AHM.

9. Ibid.

IO. Document 2, dated 3I May I893, attached to "Guerra em Maubara," Processo 376, AHM.

II. "Causas remotas," 29 August I893, folio 3, AHM.

I2. This and the next paragraph are based on "Causas remotas," 29 August I893, folios 5-6, AHM.

I3. Ibid.

I4. Interview with José Lino dos Reis, I2 July 2003, Guico, Maubara.

I5. Buru Bara was born in Atsabe, in Ermera district; his cousin aswain (warrior) Matias was born in Guico, Maubara.

I6. There are carvings on the stone outcroppings at the location that one informant attributes to her forefather named Sera Mau, who was a friend of Maubute. Interview with Rosaria Felipe, I6 August 2003, Pauinana hamlet, Vatuboro, Maubara.

I7. "Causas remotas," 29 August I893, folio I7, AHM.

I8. Ibid.

19. The earliest mention of suprahamlet administrative structures (called suco in Tetum) in Maubara appears in the colonial gazette in 1903, though these may have been established a few years earlier.

20. Rei Preto is Portuguese for "black king," and according to sources this individual was indeed very dark-skinned. His Tokodede name may have been Mau Metan, meaning "the black one." "Repreto" may be a local corruption of a military rank bequeathed by the Portuguese or Dutch during the first half of the eighteenth century.

2I. "Causas remotas," 29 August I893, folio 9, AHM.

22. Although not named in the colonial documents, the coronel regent in question appears to be Dom Gaspar of Vatuvou, nephew of the deceased Dom Carlos.

23. Governor Forjaz informed Lisbon that he had received a letter from a Dutch official in Atapupu warning him that emissaries from Maubara had come "to ask for the Dutch flag." Cypriano Forjaz, letter dated 20 June I893, IR-002-Cx.005, AHU. 
24. There is no evidence to suggest that either of these rulers actually supported the rebellion.

25. "Causas remotas," 29 August I893, folio 9, AHM.

26. Governor Cypriano Forjaz, letter to Ministry of Overseas, dated 27 May I893, IR-002_Cx.005, AHU; "Relatorio: b) Ataque pelos revoltosos e providencias que tomei," 29 August I893, folio I2, in Processo 373, AHM.

27. Davidson, "Portuguese Colonisation of Timor," I82. Personal communication with Mau Dua, 3 August 2003, Lauana, Maubara. This was not entirely anomalous: in I889 rebels in Lautem, at the eastern end of the territory, also raised a Dutch flag; see Pélissier, Timor en Guerre, II4-II5.

28. Processo No. 376, dated 27 May I893, Serie R., AHU, quoted in Davidson, "Portuguese Colonisation of Timor," 7I. (This quotation is not found in the copy of Processo No. 376 obtained in AHM.) The rumor that the Portuguese intended to sell the territory was not entirely unfounded: in 1888 a member of the Portuguese parliament had proposed selling or trading Portuguese Timor. See also "Alienção de Timor," O Independente, 29 May I888.

29. "Causas remotas," 29 August I893, folio II, AHM.

30. Ibid. The "moons of gold" are most likely sacred medallions called belak.

3I. In Lissalara today there is a separate house called Besi Mau Mau Krusa that is responsible for overseeing the ritual sphere. This is a formal distinction, but in practice members of both the Doutels' house No Liku No Besi and the related house Besi Mau Mau Krusa are actively involved in ritual. Information provided by Martinho, 8 September 20I2, Lissalara, Guguleur, Maubara.

32. There are several other instances during the late nineteenth century in which individuals identified as "ritual leaders" played a leading role in rebellion. For one such instance in the Kingdom of Funar, see BPMT I7, no. 50 (II December I87I): I99.

33. Colonial officials periodically noted the importance of alliances between the indigenous kingdoms, but their own dealings with individual rulers seldom seem to have taken these alliances seriously.

34. Cipriano Forjaz, letter dated 8 November I893, folio 4 in Processo 376, AHM. The use of the term régulo to refer to the chiefs of Daire and Vatuboro is a strange error given that these were hamlets, headed by datos, not kingdoms (reino).

35. "Causas remotas," 29 August I893, back of folio IO, AHM.

36. It has not been possible to identify this individual. In I888-I889 the colonial gazette carried several reports that the military commander in Dili had disciplined a number of soldiers, which may have led to desertions.

37. "Causas remotas," 29 August I893, back of folio IO, AHM.

38. Forjaz letter to Ministry of Overseas, 27 May I893, AHU IR-o02-Cx.005, AHU.

39. Ibid.

40. Ibid.

4I. "Ataque pelos revoltosos," 29 August I893, folio I4, AHM.

42. Forjaz letter to Ministry of Overseas, 27 May I893, AHU IR-002-Cx.005, AHU. 
43. In his long report about the rebellion, Forjaz takes full responsibility for the destruction but criticizes the captain of the Diu for interfering in the "political workings of the district." See Letter I87, Governor Forjaz to the governor of Macau, II December I893, in Processo 373, AHU.

44. The daily tally of destruction is taken from "Relatorio: c) Desenvolvimento das operações,” folios I5-20, Processo 376, AHU; see also Anténio Marques Esparteiro, A canhoeira "Diu" e a Guerra de Timor (Lisbon: Agência Geral das Colónias, I95I), I8-24.

45. A Voz de Crente, I2 August I893.

46. The government's own losses were much smaller: fifteen first-line troops, two moradores, and twenty-two auxiliaries killed. For a fascinating exploration of Portuguese military practices and Timorese headhunting in Portuguese Timor, see Roque, Headhunting and Colonialism.

47. Isabel V. Hull, Absolute Destruction: Military Culture and the Practices of War in Imperial Germany (Ithaca, NY: Cornell University Press, 2005).

48. This paragraph is based on an interview with José Lino dos Reis, I2 July 2003, Guico, Maubara.

49. Personal communication with Mau Dua, 3 August 2003, Lauwana, Maubara.

50. Interview with José Lino dos Reis, I2 July 2003, Guico, Maubara.

5I. For cholera in Dutch territory, see BOGPMT 4O, no. I (8 January I894): 3. For death figures, see “Guerra em Maubara," including letters dated 6 January I894 and 4 February I894. The most prominent casualty of the epidemic was Antonio da Costa Carvalho, a Portuguese doctor attached to the military expedition against Maubara, who died in Dili on 2I December I893.

52. Jape Kong Su thinks that his father and uncle, who were leading merchants in Maubara, erected the commemorative stone. Interviewed 7 April 2005, Dili. I would like to thank Geoffrey Wade for his translation and comments on the inscription.

53. BOGPMT 39, no. 46 (I8 November I893): 518-519. The relatives are listed as being Serelay (sic, Sereloy, also known as D. Repreto), Atebau, Mali and Maubussa.

54. Pélissier, Timor en Guerre, I28. Some informants say Dona Maria was taken to Portugal, others that she returned to Guguleur. Queen Dona Maria Manuela, whose death is recounted in Theophilo Duarte's I93I book, may be the same person, but this cannot be confirmed; see Theophilo Duarte, O Rei de Timor (Lisbon: Parceria Antonio Maria Pereira, 193I).

55. BOGPMT 39, no. 38 (23 September I893): 43I.

56. For the Doutels, interview with Mau Dua, I3 July 2003, Lauwana, Maubara; on Dom Gaspar, interview with Miguel Sanches, 3 August 2003, Maubaralissa, Maubara; and transcript of interview with Mau Lelo, I3 November 2010.

57. Reported in BOGPMT 39, no. 48 (2 December I893): 538, with the name D. José Rodriques Maubilli and the date 7 November I893; it does not report the signatories on the formal document. The handwritten copy of the terms of vassalage that was sent to Macau is dated I6 November I893. This includes twenty-seven individuals from Maubara, but many of the names and positions are illegible; 
"Cópia de termo de vassalagem do reino de Maubara, enviado pelo govêrno de Timor," Processo No. 46o, in AH/AC/Ao72O, AHM.

\section{CHAPTER 5 HIGH COLONIALISM AND NEW FORMS OF OPPRESSION, 1894-1974}

I. Davidson, "Portuguese Colonisation of Timor," I74.

2. Ibid., 197 .

3. "Commissão Municipal de Maubara: Annuncio," Boletim Official do Districto Autonomo de Timor (BODAT) 3, no. I5 (I2 April I9O2): IOI.

4. BOGPMT 4I, no. 4 (25 January I895): 28; 4I, no. 25 (22 June I895): 227.

5. For the church, see BOGPMT 42, no. 23 (6 June I896): 227; for the telegraph, see BODAT I, no. 3 (20 January I9oo): II, and no. 26 (30 June I9oo): Iog.

6. Oliveira, Timor na História Portugal, 2:406, 442; Davidson, "Portuguese Colonisation of Timor," 195.

7. David Mearns and Abel da Costa, unpublished transcript of interview with Mau Lelo, I3 November 2010.

8. Filipe Ximenes Belo, Os Anigos Reinos de Timor-Leste (Reys de Lorosay e Reys de Lorothoba, Coronéis e Datos) (Baucau: Tipografia Diocesana Baucau, 20II), 233, citing Duarte, O Rei de Timor, claims that D. José Rodriques da Silva was succeeded in 1897 by Queen Dona Maria Isabel. Informants in Maubara have never mentioned a ruler by this name. The explanation is quite simple: Duarte's account is fictional, though the figure of the queen in his book may be based on Queen Maria Doutel or José Rodrigues da Silva's wife, Colo Saka (baptized Maria Rodrigues da Silva), who was the daughter of the liurai of Deribate.

9. Davidson, "Portuguese Colonisation of Timor," 206-207, who notes that little was recorded about this campaign, possibly because of the death of Governor da Silva's favorite and much eulogized lieutenant, Francisco Duarte; interview with Francisco Soares and father, 7 July 2003, Atabae, Bobonaro. Duarte notes that some sort of trouble also arose in Guguleur but does not provide details. It is possible that villagers resisted being recruited to serve in the Portuguese military campaign against their neighbors, but I suspect that Luis took advantage of the operations to exact revenge on the Doutels, who posed a threat to his authority; see Teofilo Duarte, Timor (Ante-Camâra do Inferno?!) (Tip: Minerva, I930), 48.

Io. See, for example, "Commissão Municipal de Maubara, orcamento geral para o exercicio do anno de I900-I9OI,” BODAT I, no. 38 (22 September I900): I58.

II. Reported in BODAT I, no. 35 (I September I900): I47. This might correspond to a story Mau Lelo recounted about Luis beheading an individual in an effort to trick the Portuguese commander in Maubara into releasing his father from detention.

I2. BODAT 4, no. 7 (I4 February I903): 33, presumably showing the taxes collected the previous year. The territory-wide head tax was introduced in 1906 and greatly expanded by Governor Eduardo Marques in 1908.

I3. The appointment in Daire is reported in BODAT 2, no. I7 (27 April I9OI): 68; the appointment of a Chinese officer is in BODAT 2, no. 7 (I6 February I9OI): 28. 
I4. BODAT 5, no. I (2 January 1904): 2. He is presumably the same person as Moncura, mentioned in "Guerra em Maubara." He may have earned the respect of the Portuguese administration by participating in the I899 campaign against Atabae, during which he was allowed to give a speech prior to the military assault. See Roque, "Colonial Command of Ceremonial Language," I9.

I5. Interview with Mau Leno, 3I May 2003; Boletim Official do Governo do Districto Autonomo de Timor (BOGDAT) 8, no. 20 (I8 May I907): 9I. As a result, his nephew Asso-tem (alias Aste, baptized Carlos da Silva Santos) was made major of the second-line military and sometime later became the village head of Vatuvou.

I6. For dos Santos education at the Escolas da Missão de Lahane, see Teixeira, Macau e a sua Diocese, 4IO-4II. On the nomination, personal communication with Mau Dua, who claimed to be involved in the process, 3 August 2003, Lauwana, Maubara; and BOGDAT IO, no. 24 (I2 June I909): 89. The appointment is reported in BOGDAT II, no. 26 (25 June I9IO): I59. Sources do not indicate if the appointment was as régulo of the jurisdiction of Guguleur or of the entire kingdom.

I7. Pélissier, Timor en Guerre, 268. The suco of Vatuboro was one of the areas from which Maubute had received the strongest support during the uprisings in I886 and I893, and there is some evidence to suggest that the same families were active in both periods.

I8. Davidson, "Portuguese Colonisation of Timor," 39; Gonçalo Pimenta de Castro, Timor (Subsídios para a sua história) (Lisbon: Agência Geral das Colónias, 1944), I35; Teixeira, Macau e a sua Diocese, 394-40I.

I9. Interview with Lourindo dos Reis, I2 July 2003, Maubara Villa.

20. For a variant of this process among the ethnic Ovimbundu and Kongo of Angola, in which kingdoms were abolished but traditional titles were retained, see Linda Heywood, Contested Power in Angola, 1840s to the Present (Rochester, NY: University of Rochester Press, 2000), 35, 48-49.

2I. Nuno-Ana is the hamlet in present-day Vaviquinia that Governor Maia had razed in I886. It seems likely, though it cannot be proven, that José Nunes's father, Mau Calau, made his name by joining the Portuguese military contingent following the rebellion of I886, hence the family's close relations with the colonizers and José's educational opportunities.

22. Teixeira, Macau e a sua Diocese, 4II. José Nunes's first wife was a woman named Maria from the ruling family of Lequidoe, in Aileu; his second wife, also named Maria, was from Guguleur.

23. Interview with José Mau Cabae, I6 August 2003, Maubara. Although not explained, this account implies that Luis da Silva Maia had been released from prison in Vemasse. Patete appears to be a corruption of the Portuguese patente, meaning patent or rank.

24. Roque, Headhunting and Colonialism.

25. In I9OI he was a second lieutenant in the navy. BODAT I, no. 35 (I September I900): I47.

26. Her father, Besi Damai, had been appointed hamlet head (chefe aldeia) by the Portuguese; her mother, Cau Ana, was from Vatuboro. Interview with José Mau 
Kabae, I6 August 2003, Vatuvou, Maubara. Madalena's brother Berdade became chefe de suco after 1945.

27. See BODAT 2, no. 38 (2I September I9OI): I58; and Fernando Rosas et al., História de Portugal, vol. 6 (Editorial Estanpa, n.d.), 290. He was killed while escorting prisoners from Manufahi to Dili in I9I2. Interview with his great-grandson, João Goncalves, Io April 2006, Dili.

28. Pélissier, Timor en Guerre, 233.

29. Chaves is commonly known by the name (rank?) "Valdante." He purchased additional tracts of land in Guico in I9I2-I9I5.

30. He first obtained land in Ermera, then in Maubara, and finally in Boibau. He married a Timorese woman with whom he had one known son, Abel Tores Brites, who attended the elite school in Lahane and then married the neighbor's daughter, Ermelinda Chaves.

3I. The four-hundred-hectare land purchase is reported in BODAT 6, no. 48 (2 December 1905): 196. He purchased additional land in I9II and two hundred hectares in I9I3.

32. In I9OI he purchased land from D. Repreto's widow, Sabo Cau, and in I9O2 bought another piece of land from Mauvili's widow, Maria Rodrigues da Silva. See BODAT 3, no. 34 (23 August 1902): 2I5. Additional purchases are reported in BODAT 4, no. II (I4 March I9O3): 28; 4, no. I3 (28 March I9O3): IO8; and 5, no. I9 (7 May 1904): IOo.

33. 1907 census, signed by Julio Celestino de Montalvão e Rey.

34. José da Costa Nunes, "Relatório sobre Timor," reprinted in Teixeira, Macau e a sua Diocese, I7I. Did he select this location because from the time of the Loro Liurai it was associated with the "ritual" sphere?

35. In the late I920s, Maubara alone accounted for 27 percent of all producing coffee trees and 38 percent of all nonproducing coffee trees in the colony. See Duarte, Timor, I47-I49.

36. By 1927, there were still only six "whites" registered in Maubara and the "mixed" (mestizo) population had fallen to twenty-eight, possibly because children were being sent to school in the town of Liquica or Dili. See table in Duarte, Timor, n.p.

37. BOGPMT I4, no. 9 (I March I9I3): 54.

38. The Chinese merchants in 1912 included one individual born in Maubara, one born in Dili, one born in Kupang, and twelve born in Guangdong province, China. The one unmarried merchant was a widow. BOGPMT I3, no. 43 (26 October I9I2): 222-225.

39. In I9I2 George Connick Dyke (born in England?) purchased one hundred hectares of land, Harry Worsley (born in Sydney, resident of New Zealand) bought three hectares, and Osboone Anthong [sic, Osborne Anthony] O'Neill bought one hundred hectares, all in Vatuvou. BOGPMT I3, no. 42 (I9 October I9I2): 2I6-2I7.

40. Note the timing: the territory-wide head tax (imposto de capitação) was introduced in September 1906.

4I. This account was not included in the I9og Dili edition, but was added to the I9II Lisbon edition; see Zola, Timor: O Governo do General de Brigada do Quadro da Reserva 
José Celestino da Silva durante 14 Annos: Latronicios, Assassinatos e Perseguições (2 ${ }^{\text {a }}$ Serie) (Lisbon, I9II), 57. Governor da Silva accused António Paiva Gomes (I878I939), who was a Mason, of being Zola, something Gomes always denied but was in fact true. See http://genealogia.netopia.pt/pessoas/pes_show.php?id=I82546.

42. Duarte, Timor, 8I.

43. This version of the story was recounted by José Mau Kabae, I6 August 2003, Maubara. The surviving Sanches family members are unwilling to answer questions about Madalena Sanches.

44. The couple's first biological child, Maria M. Sanches, was born on II August I9II and is said to have had quite a dark complexion, unlike Madalena's first two children. This suggests that Joaquim Sanches had already begun his relationship with Madalena in late I9Iо. The colonial gazette, reporting on a land acquisition in I9I2, reports that he was married.

45. The family home in Lautekas may in fact be the old original military command post constructed in I893-I894. The layout is exactly the same as the Portuguese plans for the military command, but the dimensions are smaller. See note 7 of chapter 4 .

46. In some accounts the coffee plantation was inherited from José Montalvão da Silva; in other versions, Joaquim Sanches obtained his estate from his wife's father, Besi Damai; interview with Mau Dua, I3 July 2003, Lauwana, Maubara. Sanches legally established ownership of a large tract of land in I9I2; see BOGPMT I3, no. 49 (7 December I9I2): 289, and 3I, no. 5I (2I December I9I2): 298-299. Estimates of the size of the Sanches landholdings vary, though most sources agree that they totaled several hundred hectares.

47. See appendix $\mathrm{G}$ for details.

48. Instructions for the Military Commanders of the District of Timor, signed by Governor Celestino da Silva, 3I March I896, in Oliveira, Timor na História Portugal, 2:506; for a useful discussion, see Davidson, "Portuguese Colonisation of Timor," 2IO-2I4.

49. BODAT I7, no. 24 (I7 June I9I6): I28-I30; and no. 25 (24 June I9I6): I4O-I42.

50. BODAT I8, no. 25 (23 June); no. 26 (30 June); no. 28 (I4 July); no. 29 (2I July); no. 30 (28 July); no. 32 (II August); and no. 37 (I5 September), all I9I7.

5I. Gerard Bender, Angola under the Portuguese: Myth and the Reality (Berkeley: University of California Press, I978), I49-I55.

52. Bernard Callinan, Independent Company: The Australian Army in Portuguese Timor 1941-1943 (Richmond, Victoria: William Heinemann, 1984), I73.

53. Carlos Vieira da Rocha, Timor: Ocupação Japonesa durante a Segunda Guerra Mundial (n.p.: Sociedade Histórico da Independência de Portugal, I994), I05I07; Callinan, Independent Company, I79; interview with Jape Kong Su, 7 April 2004, Dili.

54. According to Saturnino Nunes Serrão, who worked for the Japanese regime, fifty to sixty women in Maubara were forced to become comfort women. Interview, 4 August 2003, Liquica. Also, interview with Suriano de Jesus, 27 February 2005, Maubara.

55. See Oliveira, Timor na História Portugal, 4:326. 
56. Interview with Saturnino Nunes Serrão, 4 August 2003, Liquica; interview with José Mau Cabae, I6 August 2003, Maubara. Portuguese documents list the names of Timorese who defended Portuguese interests during the Japanese occupation, but there are no comprehensive lists of the hundreds of people who were deported to Atauro.

57. On Lusotropicalism, see Bender, Angola under the Portuguese, 3-9.

58. For a Portuguese governor's account of PIDE's role, see Filipe Themudo Barata, Timor Contemporâneo: Da Primeira Ameaça da Indonesia ao nascer de uma Nação (Lisbon: Equilibrio Editorial, I998), I25-I27.

59. Interview with José Lino dos Reis, I5 August 2003, Guico, Maubara.

6o. The following account is from Martinho, son of Mau Dila, I3 July 2008, Lissalara, Guguleur, with background information from interview with José Serra, 24 September 2006, Vatuvou, Maubara. Adelino Tinoco, interviewed 6 April 2005 in Dili, told me that Malae Bessa had become "persona non grata" in Maubara, though did not explain why.

6I. Nicas dos Santos was the granddaughter of José dos Santos, the last liurai/régulo from the Doutel family.

62. For a particularly vivid account by an Australian journalist, see Robert Raymond, "Timor-Sleeping Island: For Portugal-A Financial Drain and Political Embarrassment," Bulletin, 29 February I964, I3-I8.

63. Unless otherwise noted, the information in this section is from an interview with Mao Klao (the name he used at the time), 6 April 2005, Dili.

64. Letter from M.S.A. Balikh to José Ramos Horta and Xanana Gusmão, I2 July I999, copy in the author's possession.

65. Stefan Dietrich, "Tjeritera Patigolo Arkian: Struktur und Variation in der Gründungsmythe des Furstenhauses von Larantuka (Ostindinesien)," Tribus 44 (I995): II2-48, cited in Robert Barnes, "Alliance and Warfare in an Eastern Indonesian Principality: Kedang in the Last Half of the Nineteenth Century," Bijdragen tot de Taal-, Land-en Volkenkunde I57, no. 2 (200I): 27I-3II.

66. Ernest Chamberlain, "Faltering Steps: Independence Movements in East Timor-I940s to the I970s" (Port Lonsdale, 20IO), II8, http://www.scribd. com/doc/3936642I/Faltering-Steps-Independence-Movements-in-East-TimorI940s-to-the-early-I970s (accessed 25 September 20I2), dates the founding of the Friends of Timor-Dilly to I96o and a Liberation Bureau to November I960.

67. Extensive documentation on URT-D can be found in ibid., II8-I65.

68. Balikh recited the declaration during an interview on 6 April 2005 in Dili.

69. I would like to thank Joaquim Brites for providing photocopies of the above documents.

70. "Undang Undang Dasar Uni Republik Timor Timur," signed by M.S.A. Balikh, dated 22 July 1974. The idea of a house of liurai prefigures proposals made by Jacob Xavier, the founder of Partido Povo Timor, after the restoration of independence. See Douglas Kammen, "Fragments of Utopia: Popular Yearnings in East Timor,” Journal of Southeast Asian Studies 40, no. 2 (2009): 385-408. 
7I. "Pengumuman," issued by Perwakilan Perjoangan Unit Republic Timor, signed by M.S.A. Balikh, dated 2I June I975. There is no evidence that José Ramos Horta was aware of Balikh's activities.

72. Mamdami, When Victims Become Killers, III.

73. Perry Anderson, "Portugal and the End of Ultra-Colonialism: Part 2," New Left Review I, no. I6 (I962), 95, quoting a government document from I898.

\section{CHAPTER 6 THE END OF EMPIRE AND THE INDONESIAN OCCUPATION, 1974-1998}

I. Ayers and Rubin, Valley of the Shadow.

2. Rowe, Crimson Rain.

3. There were two other minor political parties, the monarchist Klibur Oan Timur Aswain (KOTA) and the labor party Trabalhista, though both had very limited membership and popular support. See Dunn, Timor, 75 .

4. On the family background, see Mario Viegas Carrascalão, Timor: Antes do Futuro (Dili: Livraria Mau Huran, 2006).

5. F. X. Lopes da Cruz, Kesaksian: Aku dan Timor Timur (Jakarta: Yayasan Tunas Harapan Timor Lorosae, 1999).

6. His grandfather, Plinio Tinoco, came to Timor in the early twentieth century and served as an inspector in the colonial Department of Finance. The family was interned by the Japanese, and his son Fernando Plinio dos Santos Tinoco died in 1944. After the war, the second son, José Tinoco, served as a subdistrict administrator in a number of locations and married a Timorese woman from Manatuto. Adelino dos Santos Tinoco was born in 1945 in Oecusse and served in the colonial civil service in Ermera (I964-I967), Uatucarbau (I967-I970), and then Maubara (1970-1975). Interview with Adelino dos Santos Tinoco, 6 April 2005, Dili.

7. Born 23 February I95I in Suai, Covalima District.

8. According to his brother, Rui Pina, when Helio returned to Timor in early 1975 he carried a membership card for the Portuguese Communist Party in his wallet. Personal communication, 5 April 2005, Dili.

9. Ribeiro's father, Moises Asunção Afonso, was a primary school teacher in Dili in the I930s. Information from David Jeronimo, 20 November 200I, Maubara. Martins is the great-great grandson of Maubute's sister, Bui Cau. His father, Mau Kelis/Antoni, was from Caicasa and his mother, Eduarda, from Vatuboro. See appendix $\mathrm{C}$ for a detailed genealogy.

IO. Interview with Fortunato Soares and relatives, I3 July 2008, Guguleur, Maubara.

II. The chief of the Dili police force was Mario Mascarenhas, grandson of Leovigildo de Mascarenhas Inglês, one of the earliest Portuguese plantation owners in Maubara.

I2. Interview with José Lino dos Reis, I5 August 2003, Guico, Maubara.

I3. See CAVR, Chega!, chap. 7.4, I7-20.

I4. João Pina was the father of Fretilin Central Committee Member Helio Pina.

I5. Interview with José Maucabae, I6 August 2003, Maubara. Adelino Tinoco, interviewed 6 April 2005, in Dili, said that UDT did not take prisoners in Maubara. 
I6. Interview with José Lino dos Reis, I5 August 2003, Guico, Maubara.

I7. Soekanto, ed., Integrasi: Kebulatan Tekad Rakyat Timor Timur (Jakarta: Yayasan Parikesit and P. T. Bumi Restu, I976), 228. The Australian Red Cross was already providing limited assistance in Liquica.

I8. For evidence of mass graves in Maubara in September-October 1975, see photographs II8 and II9 in the Jill Jolliffe Microfilm Collection. Photographs I2O-I25 are from Vatuvou.

19. Interview with Adelino Tinoco, 6 April 2005, Dili. Carrascalão, Timor: Antes do Futuro, I08-IO9.

20. Interview with UDT prisoner Geraldo da Cruz, 5 March 2002, Daré. Interview with Lourindo dos Reis, 2 August 2003, Maubara.

2I. Personal communication with José Lino dos Reis, I5 August 2003, Dili. He reports that two UDT supporters were killed. Joaquim Soares was arrested in Gariana and detained in Darulete together with at least one hundred others, eighteen of whom were allegedly killed. Interview with Joaquim Soares, 25 July 2003, Boibau, Liquica.

22. Most sources say that Leonardo Alves, aged about thirty, was from either Manatuto district or somewhere farther east. Sources told CAVR that Ramahana was "physically eliminated" by supporters of Fretilin President Francisco Xavier do Amaral in 1976, but the commission found no evidence to support this. An Indonesian publication reports that Ramahana was killed by ABRI troops in the village of Funar, in Manatuto, in September 1976. CAVR, Chega!, chap. 7.2, I44. Villagers in Funar confirm that Ramahana is buried there.

23. In early 1943, during the Japanese occupation, José Martinho Sanches allegedly raped a young woman from the hamlet of Caicasa (who, in all likelihood, worked on the family coffee plantation). When she gave birth to a son, the family patriarch insisted that the baby, named José Alcino, be taken from the mother and raised as a Sanches.

24. Interview with José Mau Cabae, I8 August 2003, Maubara; Interview with Alcino Gomes and Isaac Carvalho, I5 May 2004, Caicasa, Maubara.

25. Various interviews, but for obvious reasons sources cannot be provided on this point.

26. In Guico village, Ramahana and his men reportedly raped women, shot livestock, and stole property, regardless of party affiliation.

27. Transcribed and translated from video footage in the possession of Coki Rahung Nasution.

28. See Jill Jolliffe, Cover-up: The Inside Story of the Balibo Five (Carlton North, Victoria: Scribe, 20OI).

29. This paragraph is based on an interview with José Lino dos Reis, I5 August 2003, Dili.

30. Jolliffe, East Timor, $2 \mathrm{I} 2$.

3I. The current coastal road along the Carimbala cliffs connecting the town of Maubara to Vatuboro was constructed by the Indonesian administration in the late I970s. 
32. The regional commands were formally established at a May 1976 Central Committee meeting held in Soibada (CAVR, Chega!, pt. 5, 4-5), but available evidence suggests that Hermenegildo Alves was operating in the area by early 1976.

33. Interview with José Lino dos Reis, I5 August 2003, Dili.

34. CAVR, Chega!, pt. 5, 4.

35. Norberta attended Portuguese school and then worked in a secretarial position in the Portuguese administration prior to 1975.

36. Interview with José Lino dos Reis, I5 August 2003, Dili; personal communication with Felix da Costa, I May 2004, Maubara, who noted that Silva, like Mau Kruma, was a mestizo. Personal communication with Lucas da Costa, who served as head of the Timor-Leste Red Cross and was based in Fatubessi in 1976, 7 April 2004, Dili. See also CAVR, Chega!, pt. 5, I8-I9.

37. Interview with José Lino dos Reis, I5 August 2003, Dili.

38. The following account is based on interviews with Jap Kong Su, 3 July 2003, Maubara, and Lay In Fa, 23 February 2004, Dili. Their accounts differ, however, in a number of respects.

39. A few days earlier the same unit had taken gold from the Hakka families in Liquica but had not arrested or killed anyone. Interview with Sung Ki Pu, II July 2003, Liquica.

40. At some point (the exact timing is not clear from the various accounts), the soldiers destroyed the Chinese temple located just to the west of the fort on the coastal road.

4I. Jap Kong Su provided the names of fifteen Hakka men and one Timorese believed to have been killed and then burned.

42. Some people claim that as many as fifty individuals are buried at the site.

43. According to Mau Dua (interviewed 2 May 2004, Lauwana, Maubara), a person from Guguleur who was working with the Indonesians started a fire seven times but the house would not burn. Finally, another person from Guguleur said a prayer and the house went up in flames.

44. See chapter I for earlier accounts of the sacred items. The cane of office was about eighty centimeters long, with a gilded handle and tip.

45. They were sent to study at an Indonesian college for civil servants before taking up their new posts.

46. Information about Mau Boesa is from Martinho, 3 December 20o9, Maubara; information about Lucas Correia is from Asuwana, interviewed 4 August 2003, Vatuvou, Maubara.

47. This includes the following individuals: Faustino Chaves Brites (I930-I999), Abel Chaves Brites (I933-I992), and Antonio Brites (I948-I98I), known as Commandante Nixon.

48. Including Floriano Chaves (?-ca. 1978), alias Lesaklemorai and often referred to as Ajunto Chaves; Bemvinda Chaves's husband Domingos Ribeiro (disappeared from prison in Dili ca. 1979); and Alexandrino Chaves (1948-?).

49. Including Rui Lobo, who disappeared in the southern sector in about 1977, and his brother Armindo Lobo, known as Commandante Besi Lau, who was executed 
in Guguleur in 1977 or 1978. Their mother was a Carrion and their father was from a dato family, descended on one side from the Doutels of Guguleur.

50. Personal communication with José Lino dos Reis, I5 August 2003, Dili.

5I. A visit by a unit based near Lolotoe, in southern Bobonaro, was described by José Pereira, personal communication, 29 October 2003, Lolotoe.

52. Martinho, Lissalara, Guguleur, Maubara, 8 September 2012.

53. In the village Maurice Bloch studied in Madagascar, the dreaded return to a village in which the holy houses had been destroyed was overcome with the help of a spirit medium. Maurice E. F. Bloch, How We Think They Think: Anthropological Approaches to Cognition, Memory, and Literacy (Boulder, CO: Westview, I998), 96-97.

54. In I980, the territorial military command recruited a number of young men from Maubara to participate in basic military training, with the aim of forming a new "territorial" battalion. The recruits were generally in poor health and put in little effort. ABRI soon dropped the plan and allowed the recruits to return home. Personal communication with Miguel Sanches, 5 December 200I, Maubaralissa.

55. See CAVR, Chega!, pt. 5, 22.

56. This version of events is from Rui Pina, personal communication, 5 April 2004, Dili, with additional details provided by Felix da Costa, interviewed I May 2004, Maubara. In Dili, the Indonesian military informed Rui Pina that his nephew was alive. The boy, baptized Helio Sanches Pina, was eventually sent to Portugal, where, following in his father's footsteps, he earned a university degree in agriculture. Rui Pina says that in 1982 he went to Fatubessi to exhume his brother's grave, but the local populace said that Mau Kruma was a great man and would not let Rui move the body. In 1988 he finally did move his brother's remains and reburied him with the other members of the Sanches family in the Santa Cruz cemetery in Dili.

57. The I963 figure is from Agência-Geral do Ultramar, Timor Pequena Monografia (Lisbon, 1970), I38; the I980 figure is from Biro Pusat Statistik, Penduduk Propinsi Timor Timur 1980: Hasil Pencacahan Lengkap (Biro Pusat Statistik Propinsi Timor Timur, 1980), 4. Comparatively, the decrease in Maubara was far less than in neighboring Liquica and Bazartete subdistricts, where the population fell by 38 percent over the same period.

58. The I980 Indonesian census shows only twelve Chinese (listed as citizens of the People's Republic of China) in Maubara. Biro Pusat Statistik Propinsi Timor Timur, Penduduk Propinsi Timor Timur 1981: Hasil Pencacahan Lengkap (Biro Pusat Statistik Timor Timur, I98I), II4.

59. Departemen Penerangan Republik Indonesia, Hasil Pemilihan Umum 1982: Anggota-anggota Dewan Perwakilan Rakyat dan Anggota-anggota Majelis Permusyawatan Rakyat Republik Indonesia (Jakarta: Departemen Penerangan RI, I983), 28.

6o. Interview with Fortunato Soares, I3 July 2008, Dili.

6I. Interview with Felix da Costa, I May 2004, Maubara, when he was serving as the subdistrict administrator. He and other informants do not recall the names of the victims.

62. On Viqueque, see "Informação sobre a situação socio-humana nas zonas de Ossu, Viqueque, Uato-Lari e Uato-Carabau, Abril 1982” (no publication 
information); on Covalima, interview with Rui Lopes, 3I October 2003, Suai, Covalima.

63. Interview with José Lino dos Reis, I5 August 2003, Dili.

64. Interview with Miguel Sanches, 5 December 200I, Maubaralissa, Maubara.

65. Interview with Felix da Costa, I May 2004, Maubara. He was arrested by the Indonesian military in July I992 and not released until February 1993. Several sources commented that he is descended from "slaves" (or more precisely captives of war) brought back to Maubara during the I9II-I9I2 Manufahi Rebellion.

66. Manuel Goncalves made written notes in 1989. Although I have not seen his notes, the oral account provided by his brother does not fit well with the oral tradition from the Doutels living in Guguleur. Interview with Alcino Gomes, I6 May 2004, Caicasa, Maubara.

67. This involved revival of the resistance in Ermera under commander Dudu and the arrival of Falintil patrols from the east.

68. For a fascinating account of Konis Santana's leadership, see Jill Jolliffe, Finding Santana (Kent Town, South Australia: Wakefield Press, 20I0), 70-9I.

69. Interview with Miguel Sanches, 5 December 200I, Maubaralissa, Maubara.

70. CAVR, Chega!, chap. 7.2, 229.

7I. In the I99os the Indonesian regime encouraged a variety of "traditional" social mechanisms, seeing these as a means to integrate elites and confer legitimacy on Jakarta's rule. For a fine example of this, see Departemen Pendidikan dan Kebudayaan, Sistem Pengendalian Sosial Tradisional di Daerah Timor Timur (Dili: Percetakan Negara, I992-I993).

72. Interview with Felix da Costa, 26 February 2005, Maubara Villa.

73. I would like to thank Abel dos Santos for this information.

74. He ran against Tito Ananias Soares and Miguel Arcanjo, older brother of Filomeno Paixão de Jesus, each of whom won two votes. Prior to his election, Martins was a section head in the Liquica provincial government. Interview with Felix da Costa, 26 February 2005, Maubara.

75. Biro Pusat Statistik, Kecamatan Maubara dalam Angka 1995 (Biro Pusat Statistik Propinsi Timor Timur, 1996), 7.

76. Alcino Goncalves, who became village head in Guguleur, charges that José Lino dos Reis claimed to be the new liurai of the former Kingdom of Maubara, earning him the moniker "Liurai Harmoko" (a reference to Suharto yes-man and Interior Minister Harmoko). Interview with Alcino Goncalves, I5 May 2004, Caicasa, Maubara. During extensive interviews, José Lino dos Reis never mentioned making such claims or the accusations against him.

77. Personal communication with José Sanches, I6 August 2003, Lauvei, Guguleur, Maubara.

\section{CHAPTER 7 SERIOUS CRIMES AND THE POLITICS OF THE PAST, 1999-2012}

I. See Douglas Kammen, "The Trouble with Normal: The Indonesian Military, Paramilitaries, and the Final Solution in East Timor," in Violence and the State in 
Suharto's Indonesia, ed. Benedict Anderson (Ithaca, NY: Cornell Southeast Asia Program, 200I), I70-I74; and Robinson, "If You Leave Us Here," 99-IO3.

2. Interview with Felix da Costa, 26 February 2005, Maubara.

3. Interview with Martinho, I7 February 2005, Guguleur, Maubara. Several sources suggested that BMP leaders Martins, Afat, and Manuel de Sousa as well as many rank-and-file members started out in the early I99os as supporters of the Indonesian Democratic Party (PDI). Personal communication with Francisco Soares and Elvis da Cruz, 4 March 2002, Dili. According to Geoffrey Robinson, "BMP grew directly out of an earlier group, Garda Paksi, established, funded and trained by Kopassus beginning in 1995." Geoffrey Robinson, East Timor 1999: Crimes Against Humanity: A Report Commissioned by the UN High Commissioner for Human Rights (Jakarta: Elsam and Hak, 2003), I69-I70.

4. Former militia members often provide contradictory reasons for joining. Antoni Sanches, for example, first told me that he joined willingly because proindependence youth had beaten him up, but he subsequently said the militia had forced him to join. Interviewed 28 July 2002, Dili.

5. Robinson, East Timor 1999, I7I.

6. The following account is based on information from Fortunato Soares and Bui Krimi, interviewed 2 May 2004, Guguleur, Maubara.

7. CAVR, Chega!, chap. 7.2, 258.

8. As an illustration of the competing accounts in circulation, then-Subdistrict Administrator Felix da Costa stated that Mau Kuru was murdered because someone (unspecified) wanted the family's cane of office. Interviewed 26 February 2005, Maubara Villa. As noted in chapter 6, the cane of office in question had been stolen in 1978.

9. Interview with Felix da Costa, 26 February 2005, Maubara Villa.

IO. For detailed descriptions of these events, see CAVR, Chega!, pt. 7.2, 250-255; and Robinson, "If You Leave Us Here," IO7-IO9.

II. Robinson, "If You Leave Us Here."

I2. Ibid., ix, estimates that fifteen hundred individuals were murdered.

I3. See, for example, Chopra, "Building State Failure in East Timor"; Anthony Goldstone, "UNTAET with Hindsight: The Peculiarities of Politics in an Incomplete State," Global Governance Io (2004): 83-98.

I4. As described in the introduction, after the initial burial, village dogs twice dug up the grave, scattering body parts in the nearby scrubland.

I5. Interview with Fortunato Soares, 2 May 2004, Lissalara, Maubara.

I6. David Cohen, Indifference and Accountability: The United Nations and the Politics of International Justice in East Timor (Honolulu: East-West Center Special Reports No. 9, June 2006), I2-I5.

I7. Interview with Fortunato Soares, 2 May 2004, Lissalara, Maubara; personal communication with a former SCU staff member, 8 February 2005, Dili.

I8. Unidentified bodies and missing remains were handed over to the forensic specialist, who did an inventory and found that SCU still had about ten unidentified bodies. Mau Kuru could well be one of these, but nothing was done to pursue the matter. 
19. I would like to thank José Lino dos Reis for translating some of the speeches delivered in Tokodede, and for introducing me to various participants.

20. This paragraph is based on information provided by Martinho, 8 September 2012, Lissalara, Guguleur, Maubara.

2I. Independent of this, reconciliation processes had previously been carried out by at least one nongovernmental organization.

22. Referred to as lisan in Tetum, though East Timorese also commonly use the Indonesian term adat. These practices are what Portuguese colonial officials once called usos e customes.

23. This and the next five sentences are based on information provided by Felix da Costa, interviewed 26 February 2005, Maubara Villa.

24. CAVR, Chega!, pt. 9, 22.

25. Ibid., 23 .

26. This appears to have been a rather opportunistic descendant of Mauvili (José Rodriques da Silva), who usurped traditional authority from the Doutels in the I89os. Revealing the success of the boycott, one former clandestine activist interviewed in 2005 insisted that CAVR had not yet carried out a community reconciliation process, when in fact it had.

27. Interview with Fortunato Soares and relatives, 2 May 2004, Lissalara, Guguleur, Maubara.

28. This passage draws on interviews with Felix da Costa, 26 February 2005, Maubara Villa, and Juanico Pereira, a civilian resistance leader in Faulara in I99899, 27 February 2005.

29. This case was grossly mishandled and resulted in an appeal. See, Cohen, Indifference and Accountability, 83-87, and Judicial System Monitoring Program, "Report on the Court of Appeal Decision in the Case of Armando dos Santos" (Dili, August 2003).

30. Interview with Fortunato Soares, I3 July 2008, Lissalara, Maubara.

3I. Andrew McWilliam, "Houses of Resistance in East Timor: Structuring Sociality in the New Nation," Anthropological Forum I5, no. I (March 2005): 27-44.

32. Benedict Anderson, "Elections in Southeast Asia," in The Spectre of Comparisons: Nationalism, Southeast Asia, and the World, ed. Benedict Anderson (London: Verso, 1998), 265-267.

33. The following account draws heavily on an interview with Miguel Sanches, 7 April 2006, Maubaralissa, Maubara, with additional information from other individuals in the village.

34. Rui Manuel's grandfather and three of his great uncles had supported UDT and were arrested by Fretilin in September. One uncle was murdered by Fretilin and the other three were released.

35. Election results as reported in Nakroma, 3 November 2005.

36. For the historical background to these communal identities and the dynamics of the 2006 crisis, see Kammen, "Subordinating Timor."

37. Suco-level results can be found in Comissão Nacional de Eleições, "Elisaun Presidente, 2007," 87. 


\section{BIBLIOGRAPHY}

\section{ARCHIVES}

Annaes Maritimos e Coloniaes

Arquivo Histórico Macau (AHM)

Arquivo Histórico Ultramar (AHU), Lisbon

Arsip Nasional Republik Indonesia (ANRI), Jakarta Timor, 2I I8I2

Colonial Government Gazette (published under various names)

Boletim da Provincia de Macau e Timor (BPMT)

Boletim Official do Governo da Provincia de Macau e Timor (BOGPMT)

Boletim Official do Districto Autonomo de Timor (BODAT)

Boletim Official do Governo do Districto Autonomo de Timor (BOGDAT)

Comité Oost-Indische Handel en Bezittingen, National Archive, The Hague, No. IO2, I794-I795

Jill Jolliffe Microfilm Collection

Kroch Library Rare and Manuscripts Collection, Cornell University

"Nederlandsch-Portugeesche Commissie vour Timor Gouv[ernemen]ts beslui-

ten, processen verbal, nota's, enz., en opname, enz. gedaan in de jaare I85I \& '52" Vereeenigde Oost-Indisch Compagnie archive (VOC)

VOC 3I5I, I765

VOC 8348, 1755

VOC 8354, I760

VOC 835I, 1758

VOC 8358,1764

VOC 3553, I779

VOC 7440,1788

\section{UNPUBLISHED DOCUMENTS}

Mohammad Saleh Akbar Balikh Archive (thirty pages, in the author's possession) Transcript of interview with Mau Lelo, Baiquinilau, Maubara, I3 November 2010. Interviewed by David Mearns and Abel dos Santos. 


\section{GOVERNMENT OF THE DEMOCRATIC REPUBLIC OF TIMOR-LESTE DOCUMENTS}

Comissão Nacional de Eleições (CNE). "Arkivu Elektróniku Sira Eleisaun Parlamentar 2012."

. "Arkivus Electróniku Prezidensial 2012 I ${ }^{\mathrm{a}}$ Ronde."

—_. "Arkivus Electróniku Prezidensial $20122^{\text {a }}$ Ronde."

. "Elisaun Presidente, 2007."

Direcção Nacional de Estatística. Sensu Populasaun no Uma-kain TLS, 2010, Vols. 2-4. Dili: Direcção Nacional de Estatística and United Nations Population Fund, n.d.

\section{GOVERNMENT OF THE REPUBLIC OF INDONESIA DOCUMENTS}

Biro Pusat Statistik. Kecamatan Maubara dalam Angka 1995. Biro Pusat Statistik Propinsi Timor Timur, I996.

—. Penduduk Propinsi Timor Timur 1980: Hasil Pencacahan Lengkap. Biro Pusat Statistik Propinsi Timor Timur, I980.

—. Penduduk Propinsi Timor Timur 1981: Hasil Pencacahan Lengkap. Biro Pusat Statistik Propinsi Timor Timur, I98I.

Departemen Pendidikan dan Kebudayaan. Sistem Pengendalian Sosial Tradisional di Daerah Timor Timur. Dili: Percetakan Negara, I992-I993.

Departemen Penerangan Republik Indonesia. Hasil Pemilihan Umum 1982: Anggotaanggota Dewan Perwakilan Rakyat dan Anggota-anggota Majelis Permusyawatan Rakyat Republik Indonesia. Jakarta: Departemen Penerangan RI, I983.

Direktorat Perlindungan dan Pembinaan Peninggalan Sejarah dan Purbakala. Pengumpulan Data Peninggalan Sejarah dan Purbakala di Daerah Tingkat I Timor-Timur. Departemen Pendidikan dan Kebudayaan, 1984.

Kantor Statistik Provinsi Timor Timur. "Direktori Desa Provinsi Timor Timur." Jakarta, 1985.

\section{NEWSPAPERS AND PERIODICALS}

Nakroma: Serviçoes de Informação de Mobilização de Fretilin (Dili)

O Independente (Macau)

Singapore Chronicle and Commercial Reporter

A Voz de Crente (Macau)

\section{ARTICLES AND BOOKS}

Agência-Geral do Ultramar. Timor Pequena Monografia. Lisbon, I97o.

Amnesty International. East Timor-Violations of Human Rights: Extrajudicial Executions, "Disappearances," Torture, and Political Imprisonment, 1975-1984. London: Amnesty International, 1985.

Anderson, Benedict. "Elections in Southeast Asia." In The Spectre of Comparisons: Nationalism, Southeast Asia, and the World, edited by Benedict Anderson, 256284. London: Verso. 
- Imagined Communities: Reflections on the Origin and Spread of Nationalism. London: Verso, I99I.

__. "Imagining East Timor." Arena Magazine 4 (April-May I993).

—. Under Three Flags: Anarchism and the Anti-colonial Imagination. London: Verso, 2005.

Anderson, Perry. "Portugal and the End of Ultra-Colonialism." New Left Review I, no. I5 (I96I): 83-IO2; no. I6 (I962): 88-I23; no. I7 (I962): 85-II4.

Araujo, Abilio de. Timorese Elites. Translated by J. M. Alberto, edited by Jill Jolliffe and Bob Reece. Bueanbeyan, New South Wales, 1975.

—. Timor-Leste: Os Loricos Voltaram a Cantar. Lisbon, 1977.

Ayers, Edward L., and Anne S. Rubin. The Valley of the Shadow: Two Communities in the American Civil War. New York: Norton, 2000.

Babo-Soares, Dionísio. "Nahe Biti: The Philosophy and Process of Grassroots Reconciliation (and Justice) in East Timor." Asia Pacific Journal of Anthropology 5, no. I (2004): I5-33.

Barata, Filipe Themudo. Timor Contemporâneo: Da Primeira Ameaça da Indonesia ao nascer de uma Nação. Lisbon: Equilibrio Editorial, I998.

Barnes, Robert. "Alliance and Warfare in an Eastern Indonesian Principality: Kedang in the Last Half of the Nineteenth Century." Bijdragen tot de Taal-, Land- en Volkenkunde I57, no. 2 (200I): 27I-3II.

Belo, Filipe Ximenes. Os Anigos Reinos de Timor-Leste (Reys de Lorosay e Reys de Lorothoba, Coronéis e Datos). Baucau: Tipografia Diocesana Baucau, 2011.

Bender, Gerald. Angola under the Portuguese: Myth and the Reality. Berkeley: University of California Press, 1978.

Bertrand, Jacques. Nationalism and Ethnic Conflict in Indonesia. Cambridge: Cambridge University Press, 2004.

Bloch, Maurice E. F. How We Think They Think: Anthropological Approaches to Cognition, Memory, and Literacy. Boulder, CO: Westview, 1998.

Blussé, Leonard. Strange Company: Chinese Settlers, Mestizo Women and the Dutch in VOC Batavia. Dordrecht: Foris, I986.

Bois, Cora du. The People of Alor: A Social-Psychological Study of an East Indian Island. Minneapolis: University of Minnesota Press, I944.

Boomgaard, Peter. "In the Shadow of Rice: Roots and Tubers in Indonesian History, I500-I950." Agricultural History 77, no. 4 (2003): 582-6Io.

Bovensiepen, Judith. "The Land of Gold: Risk, Recognition, and 'Cultural Revival' in the Central Highlands of Timor-Leste.” PhD dissertation, London School of Economics, March 2010.

—. "Spiritual Landscapes of Life and Death in the Central Highlands of East Timor." Anthropological Forum I9, no. 3 (2009): 323-338.

Boxer, Charles R. Fidalgos in the Far East, 1550-1770. Hong Kong: Oxford University Press, 1968.

—. "Portuguese Timor: A Rough Island Story: I5I5-I960." History Today 5 (I960): 349-355.

Budiardjo, Carmel, and Liem Soei Liong. The War Against East Timor. London: Zed Books, 1984. 
Callinan, Bernard. Independent Company: The Australian Army in Portuguese Timor 1941-1943. Richmond, Victoria: William Heinemann, I984.

Carey, Peter, and G. Carter Bentley, eds. East Timor at the Crossroads: The Forging of a Nation. Honolulu: University of Hawaii Press, 1995.

Carrascalão, Mario Viegas. Timor: Antes do Futuro. Dili: Livraria Mau Huran, 2006.

Castro, Affonso de. As Possessões Portuguezas na Oceania. Lisbon: Imprensa Nacional, I867.

—_. "Une Rébellion a Timor en I86I." Tijdschrift voor Indische Taal-, Land- en Volkenkunde I3 (I864): 389-409.

Castro, Gonçalo Pimenta de. Timor (Subsídios para a sua história). Lisbon: Agência Geral das Colónias, 1944.

Chamberlain, Ernest. "Faltering Steps: Independence Movements in East Timor-I940s to the I970s." Port Lonsdale, 20IO. http://www.scribd.com/doc/3936642I/ Faltering-Steps-Independence-Movements-in-East-Timor-I94Os-to-the-earlyI970s. Accessed 25 September 2012.

. "The Struggle in Iliomar: Resistance in Rural East Timor." Unpublished manuscript, 2003.

Chomsky, Noam. "Foreword." In Masters of Terror: Indonesia's Military and Violence in East Timor, edited by Richard Tanter, Desmond Ball, and Gerry van Klinken, ixxiii. Lanham, MD: Rowman \& Littlefield, 2006.

Chopra, Jarat. "Building State Failure in East Timor." Development and Change 33, no. 5 (November 2002): 979-IOOO.

—_. "The UN's Kingdom of East Timor." Survival 42, no. 3 (Autumn 200o): 27-39.

Cinatti, Rui. Arquitectura Timorense. Lisbon: Instituto de Invstigação Científica Tropical, Museu de Etnologia, 1987.

Clarence-Smith, Gervase. "Planters and Smallholders in Portuguese Timor in the Nineteenth and Twentieth Centuries." Indonesian Circle 57 (March I992): I5-30.

CNN. "Rebuilding East Timor Is a Challenge for Returning Refugees and Citizens." I5 March 2000. http://transcripts.cnn.com/Transcripts/ooo3/I5/ins.oo.htlm. Accessed 4 April 2007.

Cohen, David. Indifference and Accountability: The United Nations and the Politics of International Justice in East Timor. Honolulu: East-West Center Special Reports No. 9, June 2006.

Commissão Acolhemente, Veridade e Reconciliação. Chega! The Report of the Commission for Reception, Truth and Reconciliation in Timor-Leste. Dili, East Timor, 2005.

Coolhaas, W. Ph., ed. Generale Missiven van Gouverneurs-Generaal en Raden Aan Heren XVII Der Verenigde Oostindische Compagnie, Vol. VI:1698-1713. The Hague: Nijhoff, 1976.

— - ed. Generale Missiven van Gouverneurs-Generaal en Raden Aan Heren XVII Der Verenigde Oostindische Compagnie, Vol. VIII: 1725-1729. The Hague: Nijhoff, 1985.

Cortesão, Armando, and Avelino Teixeira da Mota, eds. Portugaliae Monumento Cartographica. Vol. 4. Lisbon, I96I.

Costa, Cristiano da, Aureo da Costa Guterres, and Justino Lopes. Exploring Makassae Culture. Baucau: Instituto Católico para Formação de Professores Baucau and Publições Matebian, 2006. 
D'Andrea, Claudia. The Customary Use and Management of Natural Resources in Timor Leste. Oxfam: GTZ-German Technical Cooperation and the Directorate of Land and Property of Timor Leste, November 2003.

Davidson, Katharine G. "The Portuguese Colonisation of Timor: The Final Stage, I850-I9I2." PhD dissertation, University of New South Wales, I994.

Dores, Raphael das. Apontamentos para um Diccionario Chorográphico de Timor. Lisbon: Imprensa Nacional, I903.

Druett, Joan. Rough Medicine: Surgeons at Sea in the Age of Sail. New York: Routledge, 2000

Duarte, Jorge Barros. “Timor pré-colonial.” Leba I (I992): 57-68.

Duarte, Teofilo. Timor (Ante-Camâra do Inferno?!). Tip: Minerva, I930.

Duarte, Theophilo. O Rei de Timor. Lisbon: Parceria Antonio Maria Pereira, I93I.

Duggan, Geneviève. "Modes of Remembering and Transmitting Knowledge: A VOC Report of I682 and Local Recollections, Island of Savu." In Tradition, Identity, and History-Making in Eastern Indonesia, edited by Hans Hägerdal, 26-67. Växjö: Linnaeus University Press, 20II.

Dunn, James. Timor: A People Betrayed. Milton, Queensland: Jacaranda Press, 1983.

Durand, Frédéric. "Three Centuries of Violence and Struggle in East Timor (I7262008)." In Online Encyclopedia of Mass Violence. 20II. http://www.massviolence. org/three-centuries-of-violence-and-struggle-in-east-timoroI726. Accessed I4 October 2012.

Esparteiro, Anténio Marques. A canhoeira "Diu” e a Guerra de Timor. Lisbon: Agência Geral das Colónias, I95I.

Farram, Steven. "Jacobus Arnoldus Hazaart and the British Interregnum in Netherlands Timor, I8I2-I8I6." Bijdragen tot de Taal-, Land- en Volkenkunde I63, no. 4 (2007): 455-475.

—. "A Preliminary Investigation into the History of the Old Fort at Maubara." http://www.tlstudies.org/pdfs/TLSA\%2OConf\%2O2OII/chp-28.pdf. Accessed 28 November 2012.

Fiedler, Hermann. "Hans Albrecht v. Plüskow als Oberhapt von Timor." Deutsche Wacht 5 (I93I): 3I.

Fox, James. "Assertion and Silence: Evidence and Entertainment from the Past in Rotenese Oral Dynastic Narratives." In Tradition, Identity, and History-Making in Eastern Indonesia, edited by Hans Hägerdal, II-25. Växjö: Linnaeus University Press, 20II.

— versity Press, I980.

—_. "Installing the 'Outsider' Inside: The Exploration of an Epsitemic Austronesian Cultural Them and Its Social Significance." Indonesia and the Malay World 36, no. IO5 (2008): 2OI-2I8.

Francis, E. A. “Timor in I83I." Tijdschrift voor Neêrland's Indie I, no. I (I838): 353-369.

Freycinet, M. Luis de. Voyage autour du Monde ... Exécuté sur les Corvettes de L.M. l'Uranie et la Physicienne pendant les Années 1817, 1818, 1819 et 1820. Paris: Chez Pillet Aîné, I827. 
Goldstone, Anthony. "UNTAET with Hindsight: The Peculiarities of Politics in an Incomplete State." Global Governance Io (2004): 83-98.

Gunn, Geoffrey. "The 50o-Year Timorese Funu." Bulletin of Concerned Asian Scholars 32, nos. I-2 (2000): 5-IO.

—_. "Revisiting the Viqueque Rebellion of I959." Unpublished manuscript, n.d. http:// geoffreycgunn.com/material/draft_viquequerebellion.pdf. Accessed I March 2014.

—. Timor Loro Sae: 500 Years. Macau: Livros do Oriente, I999.

Gunter, Janet. "Violence and 'Being in History' in East Timor: Local Articulations of Colonial Rebellion.” Master's thesis, Instituto Superior de Ciências do Trabalho e da Empressa, Lisbon, 2007.

Gusmão, Xanana. To Resist Is to Win: The Autobiography of Xanana Gusmão. Edited by Sarah Niner. Richmond, Victoria: Aurora Books, 2000.

Hägerdal, Hans. "Cannibals and Peddlars: Economic Opportunities and Political Alliance on Alor, I600-I850." Indonesia and the Malay World 38, no. III (July 20I0): 2I7-246.

- Lords of the Land, Lords of the Sea: Conflict and Adaptation in Early Colonial Timor, 1600-1800. Leiden: KITLV Press, 2012.

—, ed. Tradition, Identity, and History-Making in Eastern Indonesia. Växjö: Linnaeus University Press, 20II.

Hayner, Priscilla. Unspeakable Truths: Transitional Justice and the Challenge of Truth Commissions. New York: Routledge 2002.

Henley, David. "Conflict, Justice, and the Stranger King: Indigenous Roots of Colonial Rule in Indonesia and Elsewhere.” Modern Asian Studies 38, no. I (2004): 85-I44.

Heywood, Linda. Contested Power in Angola, 1840s to the Present. Rochester, NY: University of Rochester Press, 2000.

Hill, Helen. Stirrings of Nationalism in East Timor: Fretilin 1974-1978: The Origins, Ideologies, and Strategies of a Nationalist Movement. Otford, New South Wales: Otford Press, 2002.

Hohe, Tanja. "The Clash of Paradigms: International Administration and Local Political Legitimacy in East Timor." Contemporary Southeast Asia 24, no. 3 (December 2002): 569-589.

Horowitz, Donald. The Deadly Ethnic Riot. Berkeley: University of California Press, 200I.

Hull, Isabel V. Absolute Destruction: Military Culture and the Practices of War in Imperial Germany. Ithaca, NY: Cornell University Press, 2005.

Jolliffe, Jill. Cover-up: The Inside Story of the Balibo Five. Carlton North, Victoria: Scribe, 2OOI.

—. East Timor: Nationalism and Colonialism. St. Lucia: University of Queensland Press, 1978.

—. Finding Santana. Kent Town, South Australia: Wakefield Press, 2010.

Judicial System Monitoring Program. "Report on the Court of Appeal Decision in the Case of Armando dos Santos.” Dili, August 2003. 
Kalyvas, Stathis N. The Logic of Violence in Civil War. Cambridge: Cambridge University Press, 2006.

Kammen, Douglas. "Fragments of Utopia: Popular Yearnings in East Timor." Journal of Southeast Asian Studies 40, no. 2 (2009): 385-408.

—. "Queens of Timor." Archipel 84 (2012): I49-I73.

—. "Subordinating Timor: Central Authority and the Origin of Communal Identities in East Timor." Bijdragen tot de Tal-, Land- en Volkenkunde I66, no. 2/3 (2010): 244-269.

- "The Trouble with Normal: The Indonesian Military, Paramilitaries, and the Final Solution in East Timor." In Violence and the State in Suharto's Indonesia, edited by Benedict Anderson, I56-I88. Ithaca, NY: Cornell Southeast Asia Program, 200I.

Kent, Lia. "Local Memory Practices in East Timor: Disrupting Transitional Justice Narratives." International Journal of Transitional Justice 5 (20II): 434-455.

Kessler, L.W.A. "Eene vredesluiting op het eiland Timor en de overgave van het koninkrijk Maubara aan het Portugeesche gouvernement." Bijdragen tot de geschiedenis van Nederlandsch Indië (I89I): 24I-260.

Krieger, Heike, ed. East Timor and the International Community: Basic Documents. Cambridge: Cambridge University Press, 1997.

Lopes da Cruz, F. X. Kesaksian: Aku dan Timor Timur. Jakarta: Yayasan Tunas Harapan Timor Lorosae, I999.

Loureira, Manoel José Gomes. Memorias dos Estabelecimentos Portuguezes a L'este do Cabo da Boa Esperança. I835.

Mamdami, Mahmood. When Victims Become Killers: Colonialism, Nativism, and the Genocide in Rwanda. Princeton: Princeton University Press, $200 \mathrm{I}$.

Martin, Ian. Self-Determination in East Timor: The United Nations, the Ballot, and the International Intervention. Boulder, CO: Lynne Rienner, 200I.

Martinho, José S. Os portugueses no Oriente: Elementos para a História da Ocupação de Timor. Lisbon, I938.

—. Quatro Séculos de Colonização Portuguesa. Pôrto: Livraria Progredior, 1943.

Matos, Artur Teodoro de. Timor Português 1515-1769: Contribuição para a sua História. Lisbon: Faculdade de Letras da Universidade de Lisbon, Instituto Histórico Infante Dom Henrique, 1974.

McVey, Ruth. "Local Voices, Central Power." In Southeast Asian Transitions: Approaches through Social History, edited by Ruth McVey, I-3I. New Haven: Yale University Press, 1978.

McWilliam, Andrew. "Harbouring Traditions in East Timor: Marginality in a Lowland Entrepôt.” Modern Asian Studies 4I, no. 6 (2007): III3-II43.

. "Houses of Resistance in East Timor: Structuring Sociality in the New Nation." Anthropological Forum I5, no. I (March 2005): 27-44.

- "Introduction: Restorative Custom: Ethnographic Perspectives on Conflict and Local Justice in Timor." Asia Pacific Journal of Anthropology 8, no. I (March 2007): I-8. 
- Paths of Origin, Gates of Life: A Study of Place and Precedence in Southwest Timor. Leiden: KITLV Press, 2002.

Meilink-Roelofsz, M.A.P. Asian Trade and European Influence in the Indonesian Archipelago between 1500 and about 1630. The Hague: Martinus Nijhoff, I962.

Melville, Herman. "Whaling in the Straits of Timor." Knickerbocker, April I859, 349-359.

Mills, J. V. "Chinese Navigators in Insulinde about A.D. I500.” Archipel I8 (I979): $69-93$.

Minow, Martha. Between Vengeance and Forgiveness: Facing History after Genocide and Mass Violence. Boston: Beacon, 1998.

Morais, A. Faria de. Sólor e Timor. Lisbon: Agência Geral das Colónias, I944.

Müller, Salomon. Reizen en Ondersoekingen in den Indischen Archipel: Gedaan Tusschen de Jaren 1828 en 1836. Amsterdam, I857.

Nicol, Bill. Timor: The Stillborn Nation. Melbourne: Visa, 1978.

Oliveira, Luna de. Timor na História Portugal. Vols. I-4. I950. Reprint, Lisbon: Fundação Oriente, I999, 2004.

Oost-Indische Compagnie 1602-1800.

Osório de Castro, Alberto. A Ilha Verde e Vermelha de Timor. Lisbon: Divisão de Publições e Biblioteca Agência Geral das Colónias, I943.

Parera, A.D.M. Sejarah Pemerintahan Raja-Raja Timor: Suatu Kajian Peta Politik Pemerintahan Kerajaan-Kerajaan di Timor Sebelum Kemerdekaan RI. Jakarta: Pustaka Sinar Harapan, 1994.

Pélissier, René. Timor en Guerre: Le Crocodile et les Portugais (1847-1913). Orgeval, 1996.

Pinto, Constâncio, and Matthew Jardine. East Timor's Unfinished Struggle: Inside the Timorese Resistance. Boston: South End Press, 1997.

Pires, Benjamin Videira. A Vida Marítima de Macau no Seculo XVIII. Macau: Instituto Cultural de Macau, I993.

Ptak, Rodney. "Some References to Timor in Old Chinese Records." Ming Studies I7 (Fall 1983): 37-48.

Ramos-Horta, José. Funu: The Unfinished Saga of East Timor. Lawrenceville, NJ: Red Sea Press, 1987.

Raymond, Robert. "Timor-Sleeping Island: For Portugal-A Financial Drain and Political Embarrassment.” Bulletin, 29 February I964, I3-I8.

Rivière, Marc Serge, ed. A Woman of Courage: The Journal of Rose de Freycinet on Her Voyage around the World 1817-1820. Canberra: National Library of Australia, I996.

Robinson, Geoffrey. The Dark Side of Paradise: Political Violence in Bali. Ithaca, NY: Cornell University Press, I995.

—. East Timor 1999: Crimes Against Humanity: A Report Commissioned by the UN High Commissioner for Human Rights. Jakarta: Elsam and Hak, 2003.

—. "If You Leave Us Here, We Will Die": How Genocide Was Stopped in East Timor. Princeton: Princeton University Press, 2010.

Rocha, Carlos Vieira da. Timor: Ocupação Japonesa durante a Segunda Guerra Mundial. N.p.: Sociedade Histórico da Independência de Portugal, I994. 
Roque, Ricardo. "The Colonial Command of Ceremonial Language: Etiquette and Custom-Imitation in Nineteenth Century East Timor." In Portuguese and LusoAsian Legacies in Southeast Asia, 1511-2011, vol. 2, Culture and Identity in the LusoAsian World: Tenacities and Plasticities, edited by Laura Jarnagin, 67-87. Singapore: Institute of Southeast Asian Studies, 2012.

- Headhunting and Colonialism: Anthropology and the Circulation of Human Skulls in the Portuguese Empire, 1870-1930. Basingstoke: Palgrave Macmillan, 2010.

Rosas, Fernando, et al. História de Portugal. Vol. 6. Editorial Estanpa, n.d.

Rowe, William T. Crimson Rain: Seven Centuries of Violence in a Chinese County. Stanford: Stanford University Press, 2007.

Sá, Artur Basilio de. A Planta de Cailaco 1727: Valioso documento para a História de Timor. Lisbon: Divisão de Publicações e Biblioteca, Agência Geral das Colónias, 1949.

Sahlins, Marshall. "The Stranger-King or, Elementary Forms of the Politics of Life." Indonesia and the Malay World 36, no. I05 (2008): I77-I99.

Schulte Nordholt, H. G. The Political System of the Atoni of Timor. The Hague: Nijhoff, I97I.

Sherlock, Kevin. "East Timor: liurais and chefes de suco." Unpublished manuscript, I983.

Shoesmith, Dennis. "Timor-Leste: Divided Leadership in a Semi-Presidential System." Asian Survey 43, no. 2 (2003): 23I-252.

Silva, Helder Lains e. Timor e a cultura do café. Porto: Imprensa Portuguesa, Memórias Serie de Agronomia Tropical, 1956.

Soares, Dionísio da Costa Babo. "Branching from the Trunk: East Timorese Perceptions of Nationalism in Transition." PhD dissertation, Australian National University, 2003.

Soekanto, ed. Integrasi: Kebulatan Tekad Rakyat Timor Timur. Jakarta: Yayasan Parikesit and P. T. Bumi Restu, I976.

Souza, George Bryan. The Survival of Empire: Portuguese Trade and Society in China and the South China Sea, 1630-1754. Cambridge: Cambridge University Press, I986.

Tambiah, Stanley J. Leveling Crowds: Ethnonationalist Conflicts and Collective Violence in South Asia. Berkeley: University of California Press, I997.

Tanter, Richard, Desmond Ball, and Gerry van Klinken, eds. Masters of Terror: Indonesia's Military and Violence in East Timor. Lanham, MD: Rowman \& Littlefield, 2006.

Taylor, John. Indonesia's Forgotten War: The Hidden History of East Timor. London: Zed Books, I99I.

Teixeira, Manuel, ed. Macau e a sua Diocese, Vol.10: Missões de Timor. Macau: Tipografia de Missão do Padroado, I974.

—. Macau no Séc. XVIII. Macau: Imprensa Nacional de Macau, 1984.

— Os Ouvidores em Macau. Macau: Imprensa Nacional, 1976.

Therik, Tom. Wehali: The Female Land: Traditions of a Timorese Ritual Centre. Canberra: Australian National University, 2004.

Traube, Elizabeth. Cosmology and Social Life: Ritual Exchange among the Mambai of East Timor. Chicago: University of Chicago Press, 1986. 
Trindade, Jose, and Bryant Castro. Rethinking Timorese Identities as a Peacebuilding Strategy: The Lorosa'e-Loromonu Conflict from a Traditional Perspective. Dili: European Union's Rapid Reaction Mechanism Programme and GTZ, June 2007.

Uvin, Peter. Aiding Violence: The Development Enterprise in Rwanda. West Harford, CT: Kumarian Press, 1998.

Valdez, Francisco Cravasfos. Da Oceania a Lisboa. Rio de Janeiro, I866.

Vaquinhas, José dos Santos. "Timor." Boletim da Sociedade de Goegrafia de Lisboa 4, no. 7 (I883).

Velde, Paul, van der. A Lifelong Passion: P. J. Veth (1814-1895) and the Dutch East Indies. Leiden: KITLV Press, 2006.

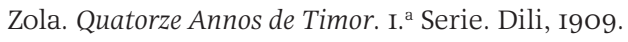

- Timor: O Governo do General de Brigada do Quadro da Reserva José Celestino da Silva durante 14 Annos: Latronicios, Assassinatos e Perseguições. 2 ${ }^{\text {a }}$ Serie. Lisbon, I9II.

\section{INTERVIEWS}

Afonso, Agusto, I4 April 2006, Erito, Guguleur, Maubara.

Alves, Jacinto, I7 July 2003, Dili.

Amaral, Clementino dos Reis, I August 2003, Dili.

Asuwana, 4 August 2003, Vatuvou, Maubara.

Bo Desi, 2 August 2003, Guguleur, Maubara.

Bui Krimi, 20 July 2008, Lissalara, Guguleur, Maubara.

Caeirro, Olandina, 24 February 2005, 6 April 2006, Dili.

Carrion, Alzira Brites, 28 February 2005, Guico, Maubara.

Costa, Felix da, I May 2004, 26 February 2005, Maubara town.

Costa, Lucas da, 7 April 2005, Dili.

Cruz, Geraldo da, 5 March 2002, Daré, Dili.

Felipe, Rosaria, I6 August 2003, Pauinana, Vatuboro, Maubara.

Francisco Soares and father, 7 July 2003, Atabae, Bobonaro.

Gomes, Alcino, I6 May 2004, Caicasa, Guguleur, Maubara.

Goncalves, João, Io April 2006, Dili.

Jap Kong Su, 3 July 2003, II July 2003, Maubara town.

Jape Kong Su, 7 April 2005, Dili.

Jeronimo, David, 29 November 200I, Maubara town.

Jesus, Suriano de, 27 February 2005, Maubara town.

Joanico dos Santos, 3I July 2002, Dili.

Joaquim Brites, II May 2004, Dili.

Joaquim Soares, 25 July 2003, Boibau, Liquica.

Jorge, 26 February 2005, Faulara, Leotela, Liquica.

José A Long, II February 2005, Dili.

José Mau Kobae, I6 August 2003, 8 April 2006, Vatuvou, Maubara.

Lay In Fa, I5 February 2005, Dili.

Lay Tek Fong, I5 February 2005, Dili.

Lemos, Ernesto, II February 2005, 5 April 2006, Dili.

Li Siom Nheu, I5 February 2005, Dili. 
Lobo, Maria de Fatima Auria, 20 July 2008, Lissalara, Guguleur, Maubara.

Lopes, Lucas Serrão, I2 July 2003, Lissadilla, Maubara.

Martinho, 24 July 2004, I7 February 2005, I9 February 2005, I4 April 2006, I5 April 2006, 8 September 2012, Lissalara, Guguleur, Maubara.

Mau Dua, I3 July 2003, 3 August 2003, 2 May 2004, Lauana, Maubaralissa, Maubara.

Mau Klao, 6 April 2005, Dili.

Mau Lelo, 3I May 2003, 25 July 2003, 8 April 2006, Maubaralissa, Maubara.

Pereira, Juanico, 27 February 2005, Faulara, Liquica.

Reis, José Lino dos, I2 July 2003, Guico, Maubara, 7 and I5 August 2003, Dili.

Rui Pina, 5 April 2005, Dili.

Sanches, Miguel, 30 May 2003, I7 February 2005, 7 and 8 April 2006, Maubaralissa, Maubara.

Santos, Abel dos, 3 September 20I2, Dili.

Santos, Marcal dos, I4 April 2006, Erito, Guguleur, Maubara.

Serra, José, 29 November 200I, I5 April 2006, Vatuvou, Maubara.

Serrão, Saturnino Nunes, 4 August 2003, Liquica town.

Silva, Fernando da, I3 July 2003, 3 August 2003, Maubaralissa, Maubara.

Silva, Lourindo dos Reis da, II July 2003, 2 August 2003, Maubara town.

Soares, Fortunato, 2 May 2004, Lissalara, Guguleur, Maubara, I July 2008, Dili, 20 July 2008, Lissalara, Guguleur, Maubara.

Sousa, José Vicente de, I March 2005, Dili.

Sung Ki Pu, II July 2003, Liquica town.

Tinoco, Adelino, 6 April 2005, Dili.

Xavier, Clemente, 9 May 2004, Caicasa, Guguleur, Maubara.

Ximenes, Simão, 4 August 2003, Maubara town. 



\section{INDEX}

Adonara, 114

Afat, José, 146, 148, 211 n3

Africa colonies, 80, 105, 113, 121-122

Africans, 71, 97, 105; soldiers, 70-71, 87, 89, 90, 94, 196n33

agriculture, 36-37; cash crops, 51, 61; rice, $36,72,110,136,163$. See also coffee

Aidaba Leten, 129

Aileu, during 1975 party conflict, 123-124; plantation labor, 106-107

Aipello, 70, 99, 136

alcohol, 25-26, 37, 58, 84, 146

Alkatiri, Mari, 161

alliance, 11-12, 19-20, 32, 42, 76, 83, 94; cross kingdom, 80, 88-89, 199n33;

Maubara-VOC, 13, 33-49, 54, 62

Alor, 24, 55, 58, 93; Maubara's claim to, $27,54,60,187 \mathrm{n} 15$; trade with, 39

Alves, Evaristo, 132

Alves, Leonardo (Ramahana), 127-128, $131,207 \mathrm{n} 22$

Amaral, Francisco Xavier, 125, 130, 161, 162, 207n22

Ambeno, 47, 49

Amsterdam, 40

Angola, 97, 102, 113, 202n20

anti-communist movement, 123, 125

Apodeti (Timorese Popular Democratic Association), 121-122, 125, 128, 131, 135 Areberra, 66

Araujo, Abilio, 5

Araujo, Fernando (Lasama) de, 162-163

arson, 72, 91-92, 124, 134

ASDT. See Social Democratic Association of Timor

assimilation, 108, 119

Asuwain Matias, 84-85

Asuwana, 157

Atabae: during Indonesian invasion, 128129, 131, 134; Maubute's flight to, 92; Portuguese campaign against, 98-99 Atambua, 101, 115, 137

Atapupu: and coffee trade, 64, 69; and 1859 territorial exchange, 55-59; in
1893 uprising, 86-87, 89

Atauro, island, 101, 110, 127-128, 205n56

Atsabe (also Atasabe), kingdom of, 55, 91, $122,186 n 12$

Australia, 106, 132, 137; military troops, 109-110

authority: in Maubara, 24-25, 27, 34, 38, $54,56,60,69,75,81,95-96,111,118$, 140-141, 160, 165; symbols of, 94, 103, 136, 148; traditional, 23, 26, 30, 40-41, 77, 97, 108, 113, 120, 136, 148

Avo Kura Fatima Lai, 29, 65

Bali, 27, 115; Balinese, 45, 47

Balibo, 127-129; kingdom of, 27

Balikh, Muhammad Saleh Akbar, 113-117

Banda, island, 32

Banitur, 110

Barnado, 28, 49-50, 76, 160

Batugade: Mau Kruma in, 128; Portuguese garrison in, 51, 54, 57, 63; URT-Dilly declaration in, 115

Baucau, 130

beeswax, 29, 39, 44, 47, 51, 69, 193n35

Berdade, 111-112, 202-203n26

Besi Merah Putih. See Red and White Iron militia

Bessa, Abilio, 112-113, 205n60

Beynon, Elias Jacob, 43-44

Boavida, Domingos, 141

border, international, 153; negotiations, 55-57, 81

Brites: family, 122, 135, 208n47; Antonio José Brites, 104

British colonies, 61, 115

British navy, 50-51

Brouwer, A. G., 52

Bui Krimi, 1, 147-148, 151-152,157-158

Buru Bara, 84-85, 92-93, 122-123, 141, 198n15

Cabreira, major, 57

Caceres: Luis Sanches de Caceres, 31-32, 188n32; Paulo Caceres, 32 
Caicassa: Apodeti support in, 122; BMP militia base, 142, 145-146; conflicts in, 128, 139, 155-156, 172; Maubute in, 81, $84,87-88$

Cailaco, 31-32, 168-169, 188n35; kingdom of, $87,89,91-92$

callades, 30, 32, 187n26, 188n35. See also kaladi

Callinan, Bernard, 109

Câmara, Filomeno da, 101

Camenassa, 25. See also Suai-Camenassa cane of office, 134, 136, 208n44, 211n8

Carlos, D., 54, 56, 58-59, 62-64, 77; descendants of, 100-111, 118, 122, 135, 138, 158-159, 164, 178

Carnation Revolution, 20, 115-116, 119, 121-122, 141

Carrascalão, João, 121, 123, 126-127

Carrascalão, Manuel, 149

Carrascalão, Mario, 121, 161

Carrion: family, 122, 135; Zeferino Antonio Carrion, 104

Castro, Affonso de, 4, 59, 61, 64

Catholic Church, 118; baptism, xii, 68; conversion to Catholicism, 97, 114, 117-118; priests, xi, 68, 105, 112, 108, $197 n 43$

cemeteries: Chinese cemetery in Maubara, 93, 133; Kakaulidun, Dili, 150, 152; Lissalara, Maubara, 65; Maubara town, 134; St. Cruz, Dili, vii, 209n56

census: Indonesian, 137, 189n45, 209n58; Portuguese colonial, 105, 111, 137

Ceylon, 30

Chaves: family, 135, 208n48; José Joaquim Chaves, 104

China, 10, 40, 120, 194n45, 209n58

Chinese, 41, 87, 98, 137, 193, 209n58; ceramics, 39, 63, 78, 148, 192n21; crime against, 68, 71; community captain, 65, 86-87, 93, 100, 194n41; detention of, 92, 110; Hakka, 65, 132, 194n45; merchants, 29, 47, 52, 57-58, 82, 90, 99, 105, 109, 203n38; population in Maubara, 65, 105-106, 195n16, 203n38, 209n58; ships, 28, 30, 31, 49, 51, 188n36

civil servants, 96, 99, 121, 141, 145, 208n45

civil war, 3, 9, 17; in the US, 11, 120

clandestine organizing, 139-140, 145, 154, 155, 159, 160-161, 164, 166

Cleto II, 51-54, 55, 59, 94. See also Doutel, José

CNRT. See National Council for Timorese Reconstruction; National Council for Timorese Resistance

coffee: introduction in Timor, 51, 192n26; and labor, 97, 100, 111; plantations, 64, 80, 105, 108, 118-119, 127, 135-136,
139-141, 147; production in Maubara, 9, 62-72, 81, 90, 99, 107, 108, 195n13; state control of, 64, 66, 98

Cold War, 120, 142

collaboration: with Indonesia, 136, 138, 142, 145; with Japanese, 110; with Portuguese, 5, 97, 103, 111, 165

colonial gazette, Portuguese, 65, 81, 94, $99,108,196 \mathrm{n} 28$

colonialism: in Africa, 92, 113, 118, 121; direct and indirect rule, 61-62; Dutch in Java, 61, 64; Portuguese, 5-6, 8, 28, 60-62, 67-69, 77-80, 96-99, 103-108, 111

comfort women, 110, 204n54

Commission for Reception, Truth, and Reconciliation, 16, 147, 155, 166

Company of Sica, 91

Conrad, Joseph, 113

Correia, Lucas, 111, 122, 135

Costa, Felix da, 139-140

Costa, Gaspar da, 69, 75, 77, 86, 94, 195n9, 198n22

Costa, Lorenzo da, 32, 188n35

Cotubaba, kingdom of, 63, 92

courts of law: Dili District Court, 151, 152; Portuguese colonial tribunal, 113. See also Special Panels for Serious Crimes

Cova, kingdom of, 27, 63; queen of, $195 n 21$

Covalima, 101

Cruz, Francisco Lopes da, 121, 124, 126-127

custom, 97, 103, 108, 117, 212n22

customs, 64, 69, 72; posts, 59, 68, 80, 87, 90, 95, 98

Daire, 26, 36, 52, 63, 80, 85-87, 89, 91, 98, 100

Daré Seminary, 124-125

dato, 38, 85, 88, 94, 111, 165, 199n34

Datu Lau, 56

decolonization, 5, 13, 17, 20, 111-113, 116, 121,125

Democratic Party, 161-164

deportees, 100, 104, 106, 122

Deribate, kingdom of, 55, 91, 186n12, $201 n 8$

Diaspora, Timorese, 2, 15, 145

Dili: as colonial capital, 42, 48-51, 79-80, 168; and displacement, 18, 131, 137, 149, 153, 161; elites in, 113, 118, 163, 165; fire in, 63; Indonesian invasion of, 130-131; 1975 party conflict in, 124-126, 131; port, 104

disease, 37, 95, 110, 184n15; cholera, 93, 98, 200n51

displacement, of population, 18, 119, 134, $137,142,161,163,168$

Diu, warship, 91, 200n43 
Dominican missionaries, 29, 43

Dotte, D., 64, 67. See also Costa, Gaspar da Doutel: family, 32, 45, 68, 101, 174-175; Antonio Doutel, 75-76; Domingos Samuel Doutel (Cleto), 44-49; Emelia Doutel, 58, 114; Francisco Xavier Doutel, 31-33; José Doutel (Cleto II), 51-55, 58-59, 65, 67, 94, 191n5, 191n13; José Nocolau Doutel (Cleto), 67, 82, 195n20; José Xavier Doutel, 44, 47-48, 50, 54, 65, 76; Maria Doutel, 65, 67, 82-83, 85-86, 195n15

Doutel political positioning: alliance with VOC, 42-50; hostility to Portuguese, 44, 62, 94, 110, 112, 118; support for ASDT, 162; support for Fretilin, 123, $125,142,165$

Doutel sacred house, 38, 78, 118, 134, 138, $140,148,158,170$

Dutch East India Company (VOC): expansion, 30; Maubara as vassal, 32-33, 42-50, 54, 60; 1759 treaty, 55, 89

dynastic rule, 13, 43, 102, 113, 161, 164-165

elections: Indonesian provincial, 140; of ruler in Maubara, 82; Timor-Leste, national, 17, 21, 159, 162-164; TimorLeste, village, 159-161

Elvaim, Francisco Pedro de Mira Feijo, 70

England: ancient alliance with Portugal, 50; occupation of West Timor, 51

Ermera, 104, 126, 131, 135, 210n67; kingdom of (Hermera), 55, 91

Esteves, ensign, 68

factionalism, 12-14, 19-20, 42-43, 85

Falintil (Armed Forces for the National Liberation of East Timor): attacks by, 140; during 1975 party conflict, 125-128; in Fronteira Norte, 1970s, 131-132, 137; in 1999, 146-147; return to western districts, 139-141, 210n67

Fatubessi, 104, 107, 131-132, 135-138, 209n56

Fatubuikaren, 92, 99, 129

Fatumasse, kingdom of, 90

Fera Lafaek, 131

Ferrão, Joaquim António da Silva, 67

Ferreira, Francisco, 73-74

Ferreira, João Gomes, 74-75

Ferreira, Manuel Alves, 101, 105

firaku, 18, 79, 161

flag: Dutch, 50, 53, 58-59, 80, 86-87, 198n23, 199n27; Indonesian, 147; Portuguese monarchy, 57-58, 63, 101; Republic of Timor-Leste, 154-155, 170-172; URT-D, 115; white flag for peace, 72,84

Flores, island, 44, 55, 114, 187n24, 188n32,
189 n46

Forjaz, Cypriano, 80-82, 84-92, 94-95, 200n43

Francis, Emmanuel, 51

Francisco Xavier, 30-32, 36, 40-41, 44-45, 135,168

Fretilin, 121, 130, 135, 160; arrests by, 125; Central Committee, 122, 131; government, 2002-2006, 154; internal conflicts, 131, 132; membership cards, 123, 125; militia in 1975, 126-127; prisoners held by, 131

Fronteira Norte, 131, 135

Gaspar, D. See Costa, Gaspar da genocide, 9, 10, 13, 16, 32

Germany, 106; colonial military, 92

Goa, 29, 31, 40, 41, 54, 80; Viceroy of, 33, 43

Gomes, Adelino, 128-129

Gomes, António de Paiva, 106, 203-204n41

Goncalves, Alcino, 141, 148, 210n76

Gonçalves, Manuel, 146, 148

Goncalves family, of Bella Vista, 122, 131, 136

Guguleur: elections in, 161-164; intravillage conflict, 122-123, 142, 155, 170, 172; jurisdiction of, 99; Portuguese military post, 98 ; reconciliation in, 155-156; rivalry with Vatuvou, 50, 60, 69, 77-78, 94; village head, 100, 111, 135, $141,145,148$

Guico, 104, 110-112, 122, 125, 141, 146, 162; elections, 161-162, 164; reconciliation in, 155

Guiné Bissau, 89

guns and gunpowder, 44, 50, 69, 147; toy guns, 154

Gusmão, José Alexandre (Xanana), 6, 7, 161-163

Guterres, Francisco (Lu Olo), 162-163

Hakka. See Chinese

Hatolia, 106, 137

heirlooms, 50, 103, 134, 138, 148, 158, 192n21

history: meaning of, $19,23,120,142,144$, 159, 169; of Timor-Leste, 4-7, 20, 60, 167-168

Hobbes, Thomas, 167

Hong Kong, 90

house (uma): autochthonous houses, 50, 142, 159; lineage house, 24-25, 30, 37-38, 97, 155, 165, 186n5; physical structure, 78, 118, 134, 138, 140, 170-171; ruling house, 40, 62, 68-69, 88; sacred, $117,140,148,158$

human rights, 4-5, 10, 15, 16, 23, 113, 144, 151-152, 169 
Ikolau, 25-26, 28, 38, 49-50, 75, 142, 159$160,188 \mathrm{n} 28$

Iliomar, 8, 132

India, 30, 33, 40; textiles, 28, 39; urban riots in, 9

Indonesia: administration in East Timor, xi, 135; democratization in, 143, 145; integration of East Timor, 125, 135, 138, 170; national legislature, 150; offer of autonomy for East Timor, 149

Indonesian military, 14, 17, 21, 119, 126, 130134, 136-138, 141, 146, 166; Air Force, 130; Army, 146; Army Special Forces Command, 140, 141, 145; covert operations, 128; government of President Habibie, 143, 150; intelligence units, 117, 123, 154; Navy warships, 129,132 ; recruitment of East Timorese, 133, 209n54

Indonesian police, 149

Integration Fighters Force, 14

International Force for East Timor, 150-152

Jakarta, 114-117, 135, 138, 145

Jap Kong Su, 133-134

Jap Nie Su, 134

Japan: invasion and occupation of Timor, 109-111, 114, 136, 204n54; Portuguese trade in, 30, 33

Java, 40, 59, 61; Dutch cultivation system in, 64

Javanese: textiles, 37, 39; traders, 29

Jesus, Agusto de, 160-161

João V, of Portugal, 33-34

Johnson, Samuel, 167

Jong Kin Siun, 134

Jurisdictions, xi, 98-99, 202n16

justice: for human rights violations, 143, 150, 152, 157, 166; traditional, 38-39, 155; transitional, 6, 16-17, 169-170

Kaisave, 25-26, 28, 49-50, 75, 142, 159-160, $188 \mathrm{n} 28$

Kalabahi, 58, 114

kaladi, 18, 79, 161, 187n26. See also callades

Kalimantan, North, 115

Kessler, L.W.A., 56-58, 65

Key Louis, 47

King of All, Brave King: see Doutels, sacred house

kingdoms, indigenous, xi, 6; alliances, 112, 199n33; colonial policy toward, 20, 48, 61, 67, 77. See also polities; vassalage

Kolana, 27, 187n15

Kopassus. See Indonesian military

Kupang: Doutel visits to, 44-45, 47, 50; VOC base in, 19. See also Dutch East India Company labor, 65, 79, 97, 100, 104, 107, 113; forced, $88,96,104-105,108,110,112,118,120$, 128

Laclo, 31-32, 59

Laclubar, 74, 122

Lacluta, 131

Lahane: palace, 74-75; school, 100, 102

Laicore, 31-32

Lakudole, 93, 113

Laku Roma, 76

Lambertus, Charles, 51

land: colonial policy, 104; concessions, 80, 104-105; disputes, 112-113, 138, 140; ownership, viii, 65, 93, 97, 108, 118; seizure of, $72,78,81,96,98,128$

Larantuka, 79, 114, 187n24; kingdom of, 114

Larantuqueiro, 189n46

Lauwana, 26, 105

law: international, 143, 169; Portuguese, 98, 108

Lay Anyi, 65

Lay Fon Fa, 134

Lay In Fa, 133

Leal Senado, 31

Leiden, adat school, 108

Leimean, 55, 186n12

Leotela, Liquica, 140

Lifau, 32-33, 42-44, 46-48, 79, 168, 187 n24, 188n35

Lima, José Joaquim Lopes de, 54-55

Lio Telo, 75-77

Liquica: church massacre, 149, 157, 170; Indonesian-era district administrator, 135, 145; Falintil in, 130-132, 139-140; during Japanese occupation, 109-110; kingdom of, 35, 47-48, 63-64, 68, 70, 79, 90; and 1975 party conflict, 121 , 126-127, 136-137

Lisbon, 40, 55, 100, 116, 121, 141. See also Portugal

Lissadilla: elections in, 161-164; Fretilin supporters, 122 ; in origin stories, 26; 2003 flag ceremony, 154-155; village head, 111, 141; under VOC, 44, 52, 191 n5 liurai, 116, 117, 118, 122, 186n10; in Maubara, 38 livestock, 37, 52, 93, 150, 157

Lobato, Lucia, 162

Lobato, Nicolau, 131

Lobo: family, 122, 135, 154, 208n49; Victor da Silva Lobo, 141

Lobo, Maria de Fatima Auria, 146

localism, 12-14

Lopes, Lucas Serrão, 171

Loro Liurai, 26, 38, 41, 44, 50, 52, 55, 77, $142,160,164,186 n 12$

Lucana. See Correia, Lucas

lulik, 38. See also house, sacred

Lusotropicalism, 111 
Macau: Francisco Xavier Doutel in, 31-33 and Portuguese colonial administration, 55, 71; and trade, 29, 40, 43

Mahubo, kingdom of, 55, 87, 89, 186n12

Maia, Alfredo de Lacerda, 62-63, 70-75, 77-78

Maia, Luis da Silva, 98-99, 102, 103, 202 n23

Maia, Manuel, 130

Makassar, 29-30, 40, 187n24; Makassarese, $11,32,36,53-54$

Malacca, 28, 30, 40

Malaya, British, 79

Mambai, 24

Manatuto: cholera in, 93; second-line troops from, 90; 1731 siege of, 32

Manila, 33

Manufahi, 101, 131, 203n27, 210n65

Manufahi Rebellion, 101, 103, 168

Mao Klao. See Balikh, Muhammad Saleh Akbar

Marathan troops, 71, 87

mardijkers, 30, 47, 191n10

Maromak Fatubessi, 132

Marquez, Eduardo, 100

marriage: alliances, 117, 187n15; customs, 24, 108

Martins, Alfredo Cardoso Soveral, 100

Martins, Francisco, 91

Martins, Leoneto, 122, 125, 135-136, 140-142, 145-146, 148-149, 206n9

Martins, Lucas, 73-75, 196n42

Martins, Norberta, 131, 137

Mascarenhas Inglês, Leovigildo de Ladislau, 104, 206n11

Matebian, mount, 139

Matos, Joachim de, 32, 188n35

Maubara: administrative divisions, 98; church, 60, 105, 134, 149, 191n16; fort, 47, 49, 59, 63, 67-68, 72, 84-85; Indonesian rule in, 132, 140-141; kingdom of, 9, 27, 29-31, 33, 43-44, 48, 53, 55, $61,67,69,72,75,80,82,88,90,94$, 143; massacre of Chinese in, 133-134; population, 35-36, 62, 105, 99, 108, 119, 137, 189n45; town, 31, 62, 65, 68, 81, 84, 90, 98, 124, 127, 148-149

Maubaralissa, elections in, 160-164; reconciliation in, 155-156; village head, 111, 141

Maubere, Emmanuel, 116

Mau Boesa, 135, 138

Maubute, 70-73, 81, 84-90, 92-95, 154, 169,176

Mau Dila, 113, 118, 123

Mau Dua, 53, 157-158

Mau Kruma. See Pina, Helio

Mau Kura, 100, 135; murder of, 1-2, 14, 23, 50, 123, 146-149; remains of, 150-152, 156-158, 166
Mau-Lado, 67

Mau Susar, 157

Mauvili. See Rodrigues da Silva, José

media, 7, 97, 113, 117

Megir, 129

Mello, Pedro de, 32

Mello, Sergio Vieira de, 15

Melville, Herman, 52

memory, 9-10

Meneses, Antonio José Teles de, 42, 48

Meneses, Magalhaes de, 31

mestizo(s), 105, 108, 118, 126, 137, 161, 203n36

military rank, 26, 44, 69, 78, 82, 103, 116, 186n9, 198n20

militias, pro-Indonesian, 1-3, 14-15, 17, 143-150, 153-157, 165

missionaries, 29, 52, 55, 57, 68, 105, 110

monarchism, 101, 103, 160, 164

Moncura. See Mau Kura

moradores: 73-75, 85, 106. See also Portuguese colonial military, second line troops

Motael, kingdom of, 31, 35, 48, 73, 75, 191n13, 196n42

Mozambique, 94, 97, 102, 113

Müller, Andries Christian, 51

municipal commissions, 99

murder, 25; of Australian journalists, 129; of Governor Maia, 73-75; of Hakka, 70, 132-134; in Maubara, 52, 63, 67, 81, 94, 99, 138, 140; of Mau Kuru, 1-2, 144, 147-149, 155-157; of Sanches brothers, 2-3, 127-128

Nagabata, 56, 59

National Council for Timorese Reconstruction (CNRT), 162, 164

National Council of Timorese Resistance (CNRT), 17, 149

nationalism, 7, 11, 14, 42, 116-118; protonationalism, 5

Netherlands, 19, 55, 57, 81, 170. See also Dutch East Indies Company

Netherlands Indies, 50-51, 55, 61, 90, 108-109, 114

Nheu family: Nheu Li Sian, 134; Nheu Pi Sian, 134; Nheu Siu Kim, 133

Noimuti, 47

Nunes family, 164, 180; Gaspar Correia da Silva Nunes, 111, 122-124, 127, 135, 138, 142; José Cirilio Nunes, 122, 139; José Nunes, 102-103, 110-111, 117

Oecusse: kingdom of, 47, 49, 54; Portuguese in, 51

Ombai Strait, 27, 35, 39, 52, 60

Opu Leki, 75-76, 160, 197n49

oral tradition, 10, 31, 33, 41, 60, 95, 142

origin stories, 24, 26, 28, 30, 40-41, 95, 160 
Paixão de Jesus, Filomeno, 137

Palapaço, 123-124

Pantar, island, 114

Paravicini, Johannes Andreas, 43-45

Pati Golo Raja Arakiang, 114

Paulo, D., 44, 48, 50

Pereira, Amelia, 73, 82

Petroleum Fund, 163

PIDE, 111

Pietersz, Jacob, 44-45

Pigafetta, Antonio, 39

Pina: Helio (Maukruma) Pina, 122, 126, 128-129, 131, 135-137; João Ferreira Pina, 122-123, 126

Pisso, kingdom of, 90

Plüskow, Hans Albrecht von, 33, 44, 47

polities, xi, 11, 27, 33, 39, 44, 55, 60-61, 112. See also kingdoms

Portugal, 19, 31, 50, 58, 81, 107, 109, 150; Caetano regime, 121; colonial policy, 67, 97, 111, 108; empire, 4, 10, 29-30, 34, 43, 121, 143; establishment of republic, 100-101, 108; Ministry of Overseas Affairs, 55, 87; Salazar regime, 13, 108-109, 111, 121

Portuguese colonial military: against Maubara, 47, 69-73, 80, 85-95; against Wehali, 186n6; border garrison, 51-52, 54, 63, 83; military officers, 103-105, 106-107; operation against Cailaco in 1726, 31-32; presence in Maubara, 59, 62-63, 66, 70, 81-84, 90; second-line, 76, 78, 103, 106

Pria, Simon Serang, 115

Quelicai, 132

Raelete, 25-26, 38, 69, 75, 142, 160

Rafael, pastor, 149

Railaco, 136

Ramahana. See Alves, Leonardo

Ramos, Guido, 161

Ramos Horta, José, 5, 7, 116, 162

rebellion, 4-5, 7, 10, 42, 59, 79, 165, 167-168, 170. See also specific locations reconciliation, 16-17, 21, 155-156, 166, 170, 212n21

Red and White Iron militia, 1, 14, 144-149, $154-155,157,165,170,172$

referendum, 1-2, 6, 13-14, 20, 143-144, $149-150,152,154,159,165$

régulo, 38, 77, 81, 97, 99, 101-102, 108, 118. See also individual rulers by name

Reinado, Alfredo, 163

Reis, José Lino dos, 123-125, 128-132, 136, 138, 141, 162, 210n76

Reis da Silva: Fernando, José Manuel, and Lucas dos, 122; Lourindo dos, 171 relocation, forced, 120, 137-138

Repreto, D., 65, 73, 86, 88, 100, 198n20

Ribeiro, Albino Antonio, 90

Ribeiro, Bishop, 112

Ribeiro, Francisco dos Santos, 122, 125, 135

riots, $7,9,12-13,161,167$

ritual: speaker, 38, 155-156, 199n32; specialist, 26, 38-39, 88, 94; sphere, $26,88,171$

Rodrigues da Silva, José (Mauvili): conflict with Doutels, 77-78, 197n51; descendants of, 138, 142, 158-160, 164; grave, 103; political rise, 67, 69, 75-76, 81-87; as régulo, 94, 98; wife, 82-83

Rouffaer, G.P., 33, 188n38

Ruak, Taur Matan, 163, 171-172

Rwanda, 10, 15

Sabah, 115

Sada Bessi, 100, 135

Salazar, Antonio, 108-109, 111, 113

Samarapo chapel, 121, 157

Same, 131

Sanches, family: 2-3, 21, 122, 125, 128, 135-136, 140-141; Alberto Sanches, 107; Jesuina Sanches, 107; Joaquim Sanches, 106-107, 122, 204n46; Joaquim Sanches (son of deportee), 123; Joaquim J.

Sanches, 127; José Alcino Sanches, 127, 207n22; José Martinho Sanches, 127; Julio J. Sanches, 127; Lucina Sanches, 122; Madalena Sanches, 104, 107, 111, 122

Sanches, Miguel, 25, 139-140, 160-162, 164,166

sandalwood, 28-29, 31, 39, 47, 51, 69, 193n35

Sanir, kingdom of, 27

Santana, Konis, 139

Santos, Armando dos, 157

Santos, Joaqim Augusto dos, 84, 86-87

Santos, José dos, 100-103, 110, 117

Santos, Nicas dos, 112

Sarawak, 115

schools: church-run, 98-99, Lahane school, 100, 102; Portuguese colonial, 107, 112-113, 119, 122, 124

self-determination, 15, 23, 113, 115, 121, 142,168

Serious Crimes Unit, 16, 144, 150-152, 158, 166

Sica, Company of, 191

Sikka, 44

Silva, Alarico da, 111-112

Silva, Antonio Eduardo da, 105

Silva, Celestino da, 96-100, 104, 106-108, 127,128

Silva, José da, 131-132

Silva, Julio Celestino de Montalvão e, 104, 107 
Silva, Rui Manuel da, 160, 162, 164

Silva Luis, Fernando da, 140-141

slaves, 12, 29-30, 37, 39, 53-54, 69, 120, 190n58, 210n65

Soares, Fortunato, 148, 151-152, 158

Social Democratic Association of Timor (ASDT, became Fretilin), 121

Social Democratic Association of Timor (ASDT, new party), 161-162, 164

Social Democratic Party (PSD), 161-162

Sociedade Agrícola Pátria e Trabalho, 104, 107

Soibada, 131, 189n42

Solor, 29, 31, 33, 43, 54-55, 114

Sousa, Manuel de, 146

South West Africa, 92

Souza, Porphyrio Zepherino de, 94

Spain, 29

Special Panels for Serious Crimes, 16, 151

state building, 4, 10, 16-17, 144

Suai, 25, 30, 36, 40-41, 68, 75, 77, 122, 157; Suai-Camenassa, 38-39, 154, 186n6

Subianto, Prabowo, 140

Suharto, 113, 135, 139, 145, 159

Sukarno, 113-115, 117

Taibessi, 126

taxation, 97, 99-100, 193n35, 201n12; head tax, 96, 99, 101, 105, 108, 111, 118

Timorese Democratic Union (UDT), 2, 121-127, 131, 135-137, 140, 142, 206n15

Timor Leste: declaration of independence, 115, 136; military (F-FDTL), 161, 163; restoration of independence, 153; state budget, 163

Tinoco, Adelino, 113, 121, 123-124, 127, 206n6

Tokodede, xi, 29

Topasse, 36, 47-48, 79, 168, 189n46. See also Larantuqueiro

treaty: 1893 treaty of Maubara, 85-86, 88; Luso-Dutch treaties, 55, 58, 87; Treaty of Berlin, 97; VOC treaty of 1759, 89

tribute, 33, 44, 57-58, 73, 99
Uatulari, 132

Ulmera, 59; kingdom of, 90

Union of the Republic of Timor-Dilly, 115-116

United Nations, 14, 16-17, 116, 144, 150, 152-153, 162, 169

Vaquinhas, José dos Santos, 66-67 vassalage, 40, 50, 78; terms of, 67, 69, 73-75, 82, 88

Vatuboro: in 1893 uprising, 85, 87, 89, 91; elections in, 160-164; in 1911-1912 rebellion, 101; polity, 26, 29, 32, 36, 44, 52; Portuguese customs post in, 80, 87; pro-Indonesian militia in, 145-146

Vatuvou: in 1893 uprising, 91; elections in, 160-165; Falintil in, 127, 132, 140; rivalry with Guguleur, 41, 50, 62, 69, 75, 77-78; village head, 100, 111, 135

Vaviquinia: Crown lands, 72-73, 81; elections in, 161-162, 164; murder in, 70; reconciliation in, 155; Portuguese attack on, 91-92; village head, 111

Vemasse, 99

village, establishment of administrative unit, 99

violence: communal, 7, 18; mass, 3, 13, 150, 165, 167-169; massacre, 47, 133134, 149, 157; production of, 10-14; recurrence of, 4, 6-9, 17-19, 60, 143, 159. See also rebellion; Indonesian, Japanese, Portuguese militaries

Wallace, Alfred Russell, 113

Weber, Max, 167

Wehali, 25, 40, 168, 186n6

West Irian, 115

West Timor: East Timorese living in, 153; relocation to, $3,15,137,150$; return from, 157; UDT flight to, 127-128 whaling, 52-53 witches, 138; witchcraft, 62, 67, 139 World War II, 5, 109, 168

Yugoslavia, 13, 15 



\section{ABOUT THE AUTHOR}

DOUGLAS KAMMEN is an assistant professor in the department of Southeast Asian studies at the National University of Singapore. His previous books are A Tour of Duty: Changing Patterns of Military Politics in Indonesia in the 1990s and the coedited volume The Contours of Mass Violence in Indonesia, 1965-1968. 
